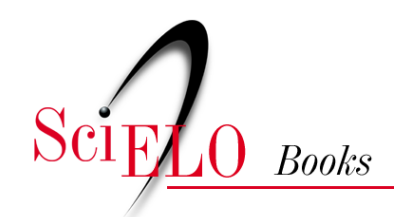

\title{
Tecnologia e o mundo da vida do jardim à terra
}

\author{
Don Ihde \\ Maurício Fernando Bozatski (transl.)
}

BOZATSKI, M.F., transI. IHDE, D. Tecnologia e o mundo da vida: do jardim à terra [online]. Chapecó: Editora UFFS, 2017, 304 p. ISBN: 978-85-64905-61-0. https://doi.org/10.7476/9788564905610.

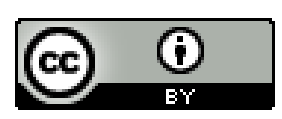

All the contents of this work, except where otherwise noted, is licensed under a Creative Commons Attribution 4.0 International license.

Todo o conteúdo deste trabalho, exceto quando houver ressalva, é publicado sob a licença Creative Commons Atribição 4.0.

Todo el contenido de esta obra, excepto donde se indique lo contrario, está bajo licencia de la licencia $\underline{\text { Creative Commons }}$ Reconocimento 4.0. 


\section{Tecnologia e o Mundo da Vida: do Jardim à Terra Don Ihde}

Tradução e notas

Maurício Fernando Bozatski

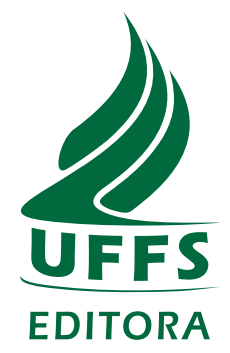


Reitor

Jaime Giolo

Vice-Reitor

Antônio Inácio Andrioli

Diretor da Editora UFFS

Valdir Prigol

Chefe do Departamento de Publicações Editoriais

Fabiane Pedroso da Silva Sulsbach

Revisora de texto

Marlei Maria Diedrich

Secretária Executiva

Claudiane Brito de Almeida

Conselho Editorial

Marlon Brandt (Presidente)

Tiago Vecchi Ricci

Gilmar Roberto Meinerz

Demétrio Alvez Paz

Paulo Afonso Hartmann

Leandro Galon

Thiago Bergles Bitencourt

Gustavo Acrani

Vanderleia Laodete Pulga

Adelita Maria Linzmeier

Rozane Marcia Triches

Antonio Marcos Myskiw

Valdir Prigol

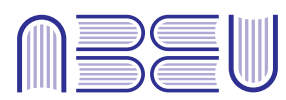

Associação Brasileira das Editoras Universitárias 
Título original:

Technology and the Lifeworld: From Garden to Earth

TECHNOLOGY AND THE LIFEWORLD: FROM GARDEN TO EARTH by Don Ihde;

(C)1990 DON IHDE

Portuguese language rights licensed from the original English-language publisher, Indiana University Press.

I25t Ihde, Don

Tecnologia e o mundo da vida: do jardim à terra. / Don Ihde ; tradutor: Maurício Fernando Bozatski. -

Chapecó : Ed. Universidade Federal Fronteira Sul, 2017.

307 p. : il. - (Indiana Series).

Título original: Technology and the lifeworld: from garden to earth.

ISBN: 978-85-64905-62-7 (e-book).

ISBN: 978-85-64905-61-0 (e-pub).

1. Filosofia da tecnologia. 2. Tecnologia - Filosofia.

3. Ciência e Tecnologia - Filosofia. 4. Tecnologia - Aspectos culturais. 5. Tecnologia - Aspectos filosóficos. I. Título. II.Série.

CDD 601

Ficha catalográfica elaborada pela

Divisão de Bibliotecas - UFFS

Nelcy T. da Rosa Kegler

CRB - 14/1311 
Para Mark Hillel Ihde 


\section{SUMÁRIO}

PREFÁCIO À EdiÇÃo BRASILEIRA ............................................................ 6

PREFÁCIO

INTRODUÇÃO: NÍVEL BÁSICO .................................................................. 16

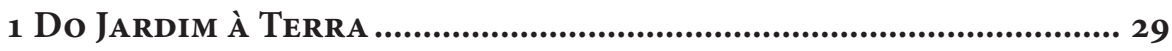

2 Tecnologia e o Mundo da Vida ...................................................... 42

3 MUNdo dA VIdA: PRÁXIS E PERCEPÇÃo............................................... 55

A. O Martelo de Heidegger..........................................................................55

B. O Galileu de Husserl ...................................................................................59

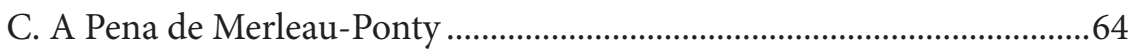

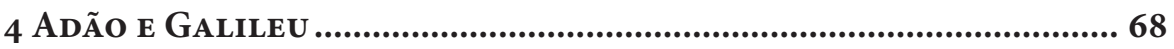

A. Técnicas do Mundo da Vida: percepção do tempo ....................................8 88

B. Técnicas do Mundo da Vida: percepção do espaço ...................................95

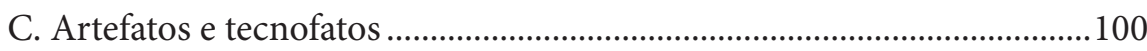

5 Programa Um: A Fenomenologia da Técnica ............................... 105

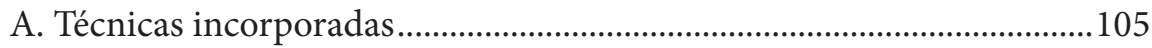

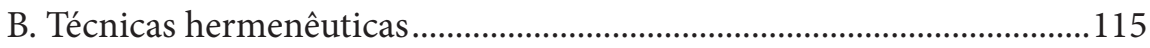

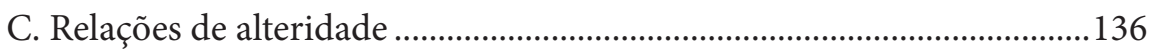




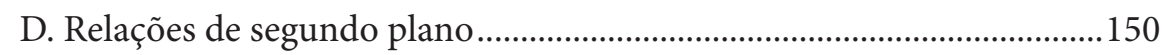

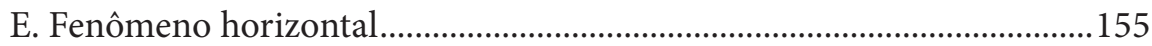

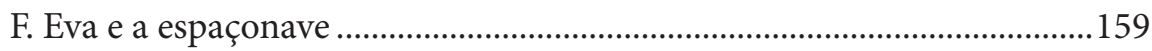

G. Sonhos de totalização ................................................................................. 162

6 Programa Dois: Hermenêuticas culturais ................................. 170
A. Transferência tecnológica: tecnologias como instrumentos culturais.171
B. Neocolonialismo como a falha da transferência ......................................180

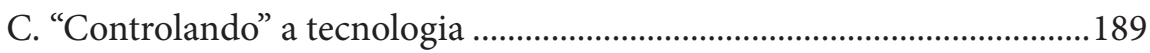
D. Incorporação da cultura-tecnologia como multiestabilidade.................195
E. As variedades da experiência tecnológica................................................203
F. A revolução culinária de Adão e Eva ......................................................211

7 Programa Três: Contornos do Mundo da Vida .......................... 217

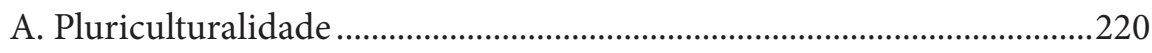

B. Carga decisional ......................................................................................2 237

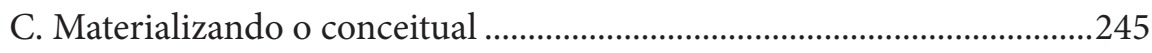

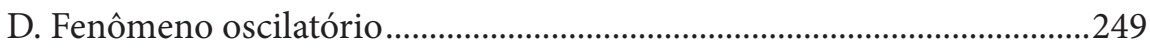

8 Epílogo: A Terra Herdada ............................................................... 255

Recomendações de manejo para a Terra Herdada ............................... 260

A. Conservar a Terra .............................................................................2260

B. Desmitificando (e desmasculinizando) a Ciência Tecnológica..............267

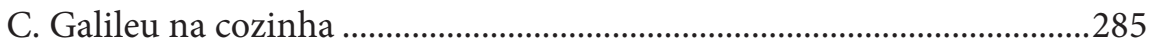

D. Concluindo: Posfácio sobre a Ciência Tecnológica ........................ 288

Posfácio: Entrevista com Don Ihde - vinte e SETE ANos de Tecnologia E O MUNdo dA VIDA .................................................. 296

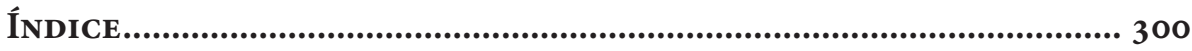




\section{Prefácio À edição brasileira}

É com grande satisfação que eu abro esta tradução brasileira de Tecnologia e o Mundo da Vida. Apenas recentemente eu fui capaz de visitar o Brasil e seu exuberante ambiente natural de florestas e cachoeiras, borboletas e pássaros e de conviver com pessoas vibrantes. Graças a Maurício Bozatski e suas habilidades de tradutor e seu entusiasmo pela Filosofia da Tecnologia e ao cometimento da Editora UFFS, é que este livro agora está disponível para a leitura em língua portuguesa.

Eu considero Tecnologia e o Mundo da Vida como o meu trabalho mais sistemático sobre as relações humano-tecnologia e, embora sua primeira publicação conte já com mais de duas décadas, ele continua muito atual. A minha fenomenologia da técnica que está aqui tem sido republicada em quase todas as antologias sobre Filosofia da Tecnologia em língua inglesa e traduzida para muitos outros idiomas. Mas, pessoalmente, olhando para trás, eu tenho orgulho em dizer que minhas previsões na seção "Formas do mundo da vida" também se saíram muito bem. Eu aprendi muitas lições sobre as dificuldades em prever quais as trajetórias e direções das tecnologias que serão afetadas pelas formas como o humano e a cultura respondem a elas, mas sobre estas eu estou correto.

Antes de Tecnologia e o Mundo da Vida, meu Technics and Praxis (1979) tem sido citado como sendo o primeiro livro em língua inglesa sobre a Filosofia da Tecnologia. Isso significa que eu tenho trabalhado muitos anos com o que hoje eu denomino melhor de "tecnosciência", esta ligação dominante entre ciência-tecnologia que faz do mundo contemporâneo, pós-moderno, o que ele é.

Minhas origens filosóficas incluem as três maiores correntes tradicionais contemporâneas da filosofia - a analítica, a pragmática e, principalmente, a 
hermenêutica-fenomenológica. No que concerne às tecnologias, eu não penso que seja acidental que as filosofias da práxis tenham dominado o campo do interesse filosófico - Marxismo e a Teoria Crítica, Pragmatismo e Fenomenologia. No meu caso, mesmo antes deste trabalho, comecei a entender, ainda no começo do século XX, que as filosofias da práxis precisavam ser modificadas para poder tratar com as tecnologias dos nossos tempos, cada vez mais complexas e difusa. Assim, o que hoje eu chamo de "pós-fenomenologia" denomina o estilo de análise que eu - e agora muitos outros - empreendem. Tecnologia e o Mundo da Vida nasceu num tempo crucial e com sua ênfase sobre o multiculturalismo, a incorporação e, na ontologia de inter-relações, ele também vai em direção a uma nova práxis.

Don Ihde

Distinguished Professor of Philosophy, Emeritus, Stony Brook University. 


\section{Prefácio}

A Indiana University Press tem orgulho em lançar a Indiana Series sobre Filosofia da Tecnologia com o seguinte trio: John Dewey's Pragmatic Technology, de Larry A. Hickman; Tecnologia e o Mundo da Vida: do Jardim à Terra, de Don Ihde; e Heidegger's Confrontation with Modernity: Technology, Politics, Art de Michael E. Zimmerman.

A Indiana Series é a primeira série norte-americana explicitamente dedicada à Filosofia da Tecnologia. (Existem outras séries que relatam filosofia e tecnologia, particularmente com alguns artigos interdisciplinares selecionados, mas nenhum deles totalmente devotados ao desenvolvimento de uma subdisciplina no âmbito da Filosofia). Amplamente concebidos, eles se destinam a uma ampla variedade de assuntos correlatos à tecnologia a partir de distintas perspectivas filosóficas. Filosoficamente, nossa abordagem vai ser pluralística; isso já é evidente em nossa primeira rodada de livros, os quais refletem igualmente as tendências das tradições do Pragmatismo americano e euro-americano.

Nosso trio é oportuno. Nós começamos com reavaliações radicais e novas interpretações dos dois filósofos do começo do século XX que fizeram das questões envolvendo a tecnologia centrais nas suas investigações, John Dewey e Martin Heidegger. E nós também iniciamos com uma sistemática reformulação do estatuto e do rol de questões concernentes à tecnologia em seu viés cultural descritas em Tecnologia e o Mundo da Vida. Depois, nós vamos adicionar outros volumes de natureza mais tópica e temática, com assuntos que vão desde 
Reprodução assistida, Tecnologias avançadas, Mídia e Racionalidade, Transformações tecnológicas da percepção e muitos outros.

Nossas metas são incluir críticas filosóficas e históricas e estudos interpretativos, bem como estudos originais e específicos, com uma perspectiva que é balanceada, racionalizada e rigorosamente relacionada ao novíssimo e emergente campo da Filosofia da Tecnologia.

Tecnologia e o Mundo da Vida propõe dar um ritmo para esta série. Ele procura evitar ambos os extremos utópicos e distópicos da tecnologia, que frequentemente acabam ocorrendo em relação a tal tema. Ele deriva de um contexto muito amplo de estudos científicos interdisciplinares. Nesse sentido, os dois pilares centrais são as relações entre o humano e a tecnologia e as relações de enraizamento cultural das tecnologias. É destinado para um público qualificado, porém amplo.

O que acabou de ser dito é apenas uma "perspectiva" editorial. Devido ao fato de que, neste caso, o editor é também o autor, eu aproveito a oportunidade para trocar de papel e assumir a perspectiva do autor e então descrever mais particularmente o panorama deste volume específico.

A jornada, igualmente intelectual e geográfica, por trás deste livro tem uma longa história. Por um lado, ela remonta até minha infância, numa fazenda comunitária no Kansas. Meu pai, meus tios e seus vizinhos eram todos "tecnológicos” em certo sentido. Um dos meus tios era, nos primórdios, um aviador dos velhos biplanos, que, em versões mais modernas, ainda são utilizados como pulverizadores nas plantações, e um primo em segundo grau, que costumava pousar em nossas pastagens, dava carona para meu irmão e eu no velho Aeronca. Todos haviam inventado ou sonhavam inventar alguma coisa; e, tal como inventores, meu irmão e eu arquitetamos uma máquina para levantar fardos do chão até o alto de uma carroça, um trabalho que nós não gostávamos de fazer manualmente. Existe igualmente um romantismo sobre as máquinas e a sensação de que tudo pode ser feito.

Aquele também era um tempo de transição, das máquinas de debulhar trigo de posse comunitária que eram levadas de fazenda em fazenda para debulhar o trigo à era das colheitadeiras. Colheitadeiras estas cuja multiplicação eu tenho testemunhado. No último outono, na Região de Chianti, na Itália, eu presenciei uma destas colheitadeiras, igualmente grande, mas que colhia uvas para a produção de vinho. E essa visão destruiu minha crença de que o trabalho manual ainda era amplamente usado neste processo. 
Fazer filosofia sobre a tecnologia, evidentemente, começou muito tempo depois de minha infância na fazenda. Talvez suas raízes começaram a tomar forma quando eu era um pós-graduando na Boston University e trabalhava no Massachusetts Institute of Technology (MIT) junto à elite da Faculdade de Desenvolvimento Tecnológico. Mas não foi antes de 1975, depois de eu já estar seis anos na Stony Brook, que publiquei meu primeiro artigo, "A Phenomenology of Man-Machine Relations" [A Fenomenologia das Relações Homem-Máquina], cujo título foi criticado por um revisor que o qualificou como um título "machista", forçando-me então a utilizar o termo "human-technology" [humano-tecnologia] como sendo uma expressão melhor. Depois disso, meu interesse começou a acelerar. Em 1979, publiquei uma coleção de ensaios como o primeiro volume sobre Filosofia da Tecnologia na Boston PhilosophyofSciences Series, Technics and Praxis (Reidel). Há um tempo, como uns dez anos, Filosofia da Tecnologia na América do Norte dificilmente poderia ser chamada de uma subárea da Filosofia. De fato, neste mesmo ano, o filósofo da ciência Mario Bunge escreveu: "Tecnofilosofia ainda é imatura e incerta sobre o seu objeto central e não explora o escopo total de suas próprias possibilidades. Que ela é uma ramificação subdesenvolvida da acadêmica é evidente pelo fato de que, até agora, nenhum filósofo proeminente fez dela seu foco principal ou escreveu alguma monografia importante sobre ela."

$\mathrm{Na}$ Europa, é claro, já existia uma tradição muito maior. O primeiro livro usando o título Technikphilosophie foi publicado em 1877 pelo neo-hegeliano Ernst Kapp, que morou na Alemanha e no Texas. A sociedade alemã sobre Filosofia da Tecnologia já existia há várias décadas no início da década de 1980, quando foi presidida por Friedrich Rapp (que escreveu o segundo livro sobre Filosofia da Tecnologia na Boston Series, Analytic Philosophy of Technology, 1981). Rapp e Paul Durbin, o "pai” da Sociedade para Filosofia e Tecnologia (Society for Philosophy and Technology), que já promovia encontros há algum tempo, mas que foi oficialmente organizada apenas em 1983, lançou uma conferência com filósofos seletos, americanos e alemães, doze de cada cidadania. Isso ocorreu em 1981, em Bad Homburg, Alemanha. Aquele grupo, agora expandido a um amplo círculo internacional, ainda se encontra em anos alternados, usualmente alternando também Estados Unidos e Europa.

Talvez fosse natural que tais sociedades devessem alocar-se dentre as universidades industrialmente desenvolvidas e de tecnologias avançadas do Hemisfério

1 BUNGE, Mario. “Five Buds of Techno-Philosophy," Technology in Society 1, 1979, p. 68. 
Norte. E foi neste contexto euro-americano que, até então, eu havia desenvolvido meu próprio trabalho. Por volta de 1982, entretanto, em parte em resposta a uma, de certa forma, surpreendente recepção de Technics and Praxis em regiões em desenvolvimento, comecei a receber convites das universidades do Hemisfério Sul.

O primeiro deles veio da El Rosario Universidad (em cooperação com outras três universidades) em Bogotá, Colômbia, América do Sul. Ali, num seminário sobre Filosofia da Tecnologia intensivo para o corpo docente em desenvolvimento, em fevereiro de 1982, recebi algo como um despertar sobre o provincianismo do meu contexto euro-americano anterior. Eu não descobri apenas sobre a existência de uma impressionante diferença entre o contexto sul-americano e suposições sobre ciência e tecnologia que estavam sendo feitas, mas tive que recriar meu programa inteiro já planejado enquanto eu estava no processo de atender aos novos tópicos. As preocupações euro-americanas sobre as relações entre ciência e tecnologia pareciam-me algo bordado sobre o tema mais substantivo do impacto cultural da ciência tecnologizada sobre os latinos, uma vez que ciência e tecnologia eram vistas como um simples e unitário fenômeno, divulgado amplamente através de um cenário político-cultural e que foi percebido muitas vezes como tendo uma influência negativa sobre os valores e práticas indígenas. Foi então que eu comecei a ver as tecnologias como instrumentos culturais, bem como instrumentos científicos do meu trabalho inicial.

Depois, ainda no mesmo ano, eu visitei algumas universidades na África do Sul. Recusando qualquer ajuda de custo ou bolsa governamental, mas curioso para ver em primeira-mão esta aflitiva parte do mundo, e recebendo apoio através do interesse da BMW em Filosofia da Tecnologia e da University of Zululand (uma universidade negra), eu fiquei um mês na África do Sul. A postura ali foi bem diferente daquela relativamente negativa em Bogotá. O tema da conferência principal e da série de leituras foi "Technology and Utopia” (Tecnologia e Utopia) e, em muitos setores de ciência tecnológica, foi percebido como a forma de saltar para o século XXI.

Mais recentemente ainda houve a viagem para Nova Déli, Índia. Num país em que ainda existe um vivo debate sobre a direção "gandhiana" ou "nehrudiana" na política, existe ao menos acordo sobre a retenção da autonomia nacional de desenvolvimento no contexto de uma abordagem semisocialista, com uma política oficial para o rápido e positivo desenvolvimento técnico-científico. $\mathrm{O}$ Instituto Nacional para Desenvolvimento de Ciência e Tecnologia (The National 
Institute for Science and Technology Development) é um instituto de pesquisa impressionante, servido por algumas das melhores mentes jovens da Índia, mas desafiado por uma das maiores tarefas imagináveis em face da superpopulação e da pobreza contínua.

Estas e outras experiências ajudaram a convencer-me de que um livro tentando reenquadrar a questão da tecnologia tem que levar em conta o multicultural, que é o cenário mais internacional no qual cada cultura tecnológica é tomada e terá lugar. Esta é a razão para a ênfase específica aqui, particularmente na segunda e na terceira parte do "programa" que idealizei.

O foco que eu havia escolhido inevitavelmente deixava outras dimensões do mundo tecnológico pouco desenvolvidas. Havia falhas e a maior e mais importante delas era a dimensão sociopolítica. Embora esta dimensão não estivesse completamente ausente, permanecia em segundo plano. Igualmente, a sociologia e a política da ciência tecnológica em si estavam totalmente ausentes. Eu nem havia tentado cobrir todas as fronteiras das tecnologias emergentes. A ausência mais notável era uma discussão mais profunda sobre biotecnologia, claramente de crucial importância para o futuro da tecnologia. Eu não primei muito pela abrangência, mas, ao contrário, busquei focos mais temáticos que relacionavam ciência e tecnologia às suas dimensões culturais e de vivência humana.

Também sou bem claro a respeito do papel de minhas experiências pessoais no livro. Isto tem sido sempre uma característica do meu estilo e reconheço que alguns leitores podem gostar disso e outros podem não gostar dessas vinhetas autobiográficas. Embora escritores sejam guiados por e em respostas às suas próprias experiências pessoais, tenho utilizado as minhas experiências pessoais para se prestarem, por um lado, como a base que emprega seriedade às minhas questões e, por outro, para fazer o dever de casa no âmbito da tradição acadêmica, através de uma escrita cuidadosa e ávida, para um patamar que vai além de alguma coisa simplesmente autobiográfica. Isto é o que ocorre com o caso das múltiplas culturas utilizadas como exemplos aqui. Desde os primeiros dias junto aos programas de pós-graduação na Stony Brook (em que nosso currículo demandava que ensinássemos em grupo durante um ano num trabalho interdisciplinar, no qual eu compartilhei interfaces entre Filosofia e Antropologia) à viagem a Australian National University, em 1985, destinada a aprofundar os meus estudos sobre os aborígenes e os grupos do Pacífico Sul, aos quais eu me referia, eu tenho procurado examinar e investigar o que pode ser afirmado sobre estas culturas. 
Existem mais duas experiências que são relevantes. A primeira é a questão do atraso em ter o livro pronto de acordo com a agenda inicial decorrido pelo fato de eu ter assumido o decanato das Humanidades e Artes na Stony Brook, em setembro de 1985. Embora aquele trabalho impedisse a finalização do manuscrito até eu obter uma licença para pesquisa no outono de 1988, ele me oportunizava uma experiência inédita em "sociologia e política" nas faculdades de ciência e tecnologia. Stony Brook, como é típico nas grandes universidades públicas que se destinam à pesquisa, não é apenas dominada pelas ciências (naturais), mas também é administrada nos altos níveis por uma equipe de cientistas (das ciências da natureza) transformados em gestores. Com esta situação eu aprendi muitas lições e apenas algumas delas ecoam aqui.

A outra experiência coloca o "você é o que você come" no centro de muitos dos meus contos. Durante os recrutamentos para o Departamento de Filosofia, nós costumávamos brincar que depois de determinar os indivíduos que eram boas promessas para a filosofia, as questões "reais" poderiam começar com "Que culinária você pratica?" na esperança de que um novato pudesse ser incluído no repertório social.

O banquete, como cenário para o filosofar, é ao menos tão antigo quanto o Symposium, embora eu vá um pouco longe com o que uso nos meus esforços em elaborar metáforas. Essa metáfora distante talvez possa servir, em parte, para falar sobre a finalização da escrita que ocorreu nas colinas da Toscana, Itália, na terra de uma das melhores culinárias do mundo. A escolha desta localização, feita mais por necessidade acadêmica de escapar das pressões diárias de sua própria universidade do que por qualquer outro motivo, não foi, contudo, a única razão para eu ter escolhido a Toscana.

A Toscana também possui implicações históricas e filosóficas muito fortuitas justamente por ter sido o berço do Renascimento Científico, a ciência moderna. Vinci, a vila de Leonardo, estava localizada logo na esquina da minha casa na fazenda, e Pisa, a terra de Galileu, não ficava mais que a uma hora de distância. Essa circunstância me oportunizou uma inesperada, mas agora muito apreciada, concretude para o processo de escrita.

Depois desta longa gestação, Tecnologia e o Mundo da Vida agora está finalizado. Os estágios iniciais deste livro foram possibilitados por um período sabático gozado em Paris, em 1984, seguido de um verão como Professor Visitante na Australian National University, Camberra, em 1985, mediante os auspícios de Richard Campbell e da Faculdade de Artes. O semestre de pesquisa em 
Spazzavento, Itália, no outono de 1988, foi financiado, novamente, pela Stony Brook.

O livro tomou forma no âmbito de uma comunidade intelectual. Aqui, também, o projeto iniciou na Stony Brook, mas alcançou todos os cantos do planeta. Eu sempre tive segundo e terceiro pensamentos sobre quem eu deveria mencionar e preocupações sobre quem deveria ser mencionado e em quais contextos. Dadas estas circunstâncias, vou simplesmente nominar alguns dos indivíduos que muito diretamente contribuíram nas discussões críticas e na edição, e a quem eu devoto uma gratidão especial: na Stony Brook, existe Patrick Heelan, bem como Marshall Spector, Ruth Cowan, John Truxal e, mais recentemente, Ann Kaplan; depois, também, eu devo mencionar os dois que se tornaram doutores em Filosofia da Tecnologia durante as dores do parto deste livro, Paul Thompson e Larry Kilbourne.

Uma crítica e atenção muito especial foram feitas por Robert Ackermann, Albert Borgman, John Compton e Frecerick Ferre, com discussões ampliadas por Robert Cohen, Paul Durbin, Lester Embree, Larry Hickman, Joseph Kockelmans, Lenore Langsdorf, John McDermott, Joseph Pitt, Langdon Winner e Marx Wartofsky e, recentemente, Sandra Harding, Susan Squier e Anthony Weston.

A lista de fora da América do Norte é igualmente grande e, dentre outros, eu devo citar Friedrich Rapp, Richard Sylvan, C. C. DeBerr, Maurita Harney e R. Sinari.

É claro, nada disto teria ocorrido, particularmente dentre as múltiplas pressões e esforços de viagem, decanato, e todo resto, se não fosse por minha super-secretária, Jean Kelley. Ela foi capaz de superar o sistema pré-moderno de correio italiano e obteve o manuscrito completo reduzido a disquetes durante o afastamento para o semestre de pesquisa e o recesso seguinte. Então, durante as noites e ao longo dos finais de semana, ela produziu a primeira edição de texto a partir das minhas notas e manias de inserir anotações. Eu apenas espero que ela não tenha sofrido com a nova doença causada por computadores que eu descobri na Austrália chamada LER (lesão por esforço repetitivo), que ocorre depois que se passa muito tempo diante de um computador na mesa de trabalho. Outras horas foram gastas por Curt Naser, do Instituto de Humanidades, checando as notas de rodapé e os detalhes técnicos. E Mary Jane Gormley, editora da Indiana Press, que não só corrigiu e reduziu o excesso de prosa, mas fez isso com o maior senso de humor e adicionou insights à minha longa experiência com pessoas que executam esta tarefa. 
Em casa, minha esposa Linda Einhorn-Ihde, que com seu suporte no inglês, de bom grado, me emprestou suas habilidades em gramática e estilo. E meu filho mais novo, Mark Hillel Ihde, a quem este livro é dedicado, forneceu igualmente um novo senso de entusiasmo e uma razão para ver, por meio dele, esperança nos caminhos que nossas tecnologias podem seguir no futuro. 


\section{INTRODUÇão: NÍVEL BÁSICO}

Ao longo desta última parte do século XX, aqueles dentre nós que residem nas partes industrializadas do Hemisfério Norte, vivemos, nos locomovemos e temos nosso ser em meio às tecnologias. Nós podemos até afirmar que nossa existência é tecnologicamente entrelaçada, não apenas no que diz respeito aos pontos críticos que emergem numa civilização tecnológica tal como a ameaça de uma guerra nuclear ou a preocupação sobre a poluição global e seus possíveis efeitos irreversíveis, mas também no que diz respeito aos ritmos e espaços da vida cotidiana.

Se nós iniciarmos esta investigação com uma ampla, mas também empírica e concreta noção das tecnologias como sendo os artefatos da cultural material, as quais nós utilizamos em vários sentidos em nosso meio ambiente, poderemos começar, então, um calendário cotidiano de nossas interações humano-tecnologia que se provariam escalonadas numericamente. Imagine a abordagem mais mundana, cotidiana, que poderia iniciar pelos nossos primeiros movimentos.

É provável que nós sejamos chamados à consciência desperta por uma tecnologia, seja o soar de um alarme, o alarme de um relógio de quartzo ou os sons de um rádio-relógio.

O primeiro exame feito, assim que relutantemente deixamos o calor de nossa cama, pode revelar que nosso sono tem sido assegurado por nossas tecnologias relativas ao ato de dormir (seja por algum tipo de tecnologia avançada, tal como um cobertor elétrico ou de média tecnologia como a de um cobertor sintético, ou ainda por algum tipo de baixa tecnologia, tal como alguma fibra natural, que não é menos que uma tecnologia, pois passou por um processo de transformação implicando em tornar-se uma tecnologia). 
Levantar-se torna-se um processo ainda mais associado ao contexto de tecnologias complexas, ao passo que nos movemos para o banheiro. Um vasto sistema de encanamento é empregado, a história dos quais remonta desde os etruscos e romanos, mas que hoje em dia emprega um vasto sistema hídrico e materiais oriundos da indústria do plástico e da metalurgia.

Então nós desjejuamos numa cozinha provavelmente dominada por aparelhos elétricos e que contrastam ainda mais com as cozinhas ao longo da história. As máquinas automáticas (torradeira, cafeteria provavelmente presentes com forno de micro-ondas, máquinas de lavar pratos, etc.) nos permitem fazer a primeira refeição do dia sem muito esforço.

Depois de acordar e comer, é provável que deixemos o lar por meio de um sistema de transportes com intrincados e extensos envolvimentos em redes. Nossos novos automóveis até mesmo nos informam sobre suas condições através de um sistema computadorizado e instrumentos eletronicamente dispostos que evidenciam sua forma de comunicação humano-tecnologia.

Todas essas atividades mundanas serão provavelmente acompanhadas por outras dimensões da interação humano-tecnologia. Por exemplo, enquanto comemos, a televisão pode estar conectada com o mundo; enquanto dirigimos para o trabalho, o rádio entretém ou informa; e se o motorista for mais workaholic, o editor de texto por voz também pode ser empregado.

Esta primeira hora da experiência do despertar já é suficiente para demonstrar o quanto nossas atividades são interconectadas com tecnologias. Permitam-me citar dois exemplos menos ordinários para demonstrar o mesmo entrelaçamento.

Algumas vezes a recreação toma a forma de uma escapada da intensa saturação da cultura material e urbana. Por exemplo, alguém pode desejar se retirar para um dos nossos muitos "museus naturais", reservas que protegem a vida selvagem, parques, e coisas do tipo. Uma forma de desafio durante tal recreação pode ser a escalada de montanhas. A subida vai empregar ganchos e mosquetões de ligas metálicas, cordas de escalada, calçados de escalada especialmente manufaturados e, para uma escalada durante a noite, provavelmente uma barraca leve de fibra artificial, equipamentos de cozinha em miniatura e comida desidratada.

Num contexto mais íntimo, as mesmas observações podem ser feitas sobre a prática sexual no século XX. O que as pessoas contemporâneas empregam em suas relações sexuais sem alguma decisão em relação às tecnologias de controle de natalidade? A simples consciência de que existem tais técnicas envolvendo 
tecnologias de controle mudou o contexto da prática sexual. A “decisão" de não utilizar tais dispositivos é tomada à luz de sua experiência já conhecida. E o fato, em muitos casos, é precisamente a falta do uso ao invés do então agora comum uso que implica uma desaprovação social. Num nível demográfico, o tamanho reduzido das famílias na maioria das sociedades industrializadas demonstra o quão normatizada esta prática é.

$\mathrm{Na}$ nossa era, em contraste às sociedades mais tradicionais, a decisão de conceber filhos é uma exceção à norma de não conceber, e a responsabilidade para a concepção está claramente relacionada ao nosso conhecimento e uso das tecnologias contraceptivas. Isso pode ser bem ilustrado pelo que nós tomamos como sendo o maior problema social em sociedades com tecnologia avançada, isto é, gravidez na adolescência. Primeiro, gravidez na adolescência é considerado um problema na maioria destes países em contraste com o que é de fato a norma em muitas outras culturas de tradição diferente. Segundo, o problema surge não tanto por causa da aceitação ou não aceitação da atividade sexual adolescente como tendo "falhado" ao aderir em tal atividade "responsavelmente". Para o espanto de muito professores iniciantes e voluntários em programas ligados às adolescentes grávidas, o que é usualmente descoberto é que havia conhecimento de controle de natalidade, mas um tipo de "decisão" frequentemente através de uma passividade comportamental foi tomada em relação a não usar anticoncepcionais. Seja qual for a razão, a expectativa social é que adolescentes são responsáveis apenas se evitarem possíveis gravidezes, o que é dizer que tal responsabilidade implica o uso das tecnologias disponíveis.

Tudo isto é familiar, incluindo a variedade e extensão às quais nossas atividades diárias estão envolvidas com tecnologias. E é por esta familiaridade que podemos simplesmente negligenciar tanto a necessidade de uma reflexão crítica sobre os resultados a serem atingidos quanto os impactos em nossas vidas dentro deste sistema tecnologicamente entrelaçado, sistema tal que poderia ser denominado mais adequadamente de tecnosistema. De fato, esta familiaridade pode ocasionar em sermos surpreendidos quando alguém for caracterizar esta vida como sendo, de alguma forma, peculiar.

No entanto, uma séria reflexão poderá começar apenas ao tomar-se uma distância suficientemente precisa deste nosso envolvimento mundano em que algum senso de sua singularidade, mesmo peculiaridade, possa ser apreendido. Existe uma ampla variedade de questões importantes, existenciais, à espreita, dentro do reino tomado, muitas vezes, como certo de nossas atividades cotidianas. 
Também não nos falta uma consciência comum de alguns destes problemas, que tomam a forma de crenças populares em certo sentido, mas que possuem contrapontos mesmo dentro dos alcances mais sofisticados de especialização. As seguintes perguntas e debates que as acompanham são indicativos:

Quão semelhante, ou diferente, é a nossa vida dentro do nosso tecnosistema, das formas de vida anteriores ou diferentes que os humanos já viveram? As consciências popular e especializada oferecem uma resposta mista a esta questão. De um lado, a crença talvez dominante é a de que as tecnologias contemporâneas são, de alguma forma, essencialmente e dramaticamente diferentes de todas as tecnologias passadas. Isto significa que deve existir alguma disjunção razoavelmente dramática entre nós e o passado, e entre aqueles que estão em sociedades amplamente industrializadas e tecnológicas, e aqueles que não vivem ainda no âmbito de tal tecnoesfera.

Mas seria este o caso? E, se sim, em quais aspectos? Robert Oppenheimer, o físico do Projeto Manhattan, teria dito ter observado que há mais físicos vivendo hoje do que em todos os séculos anteriores (dito ao qual o humorista Art Buchwald deu a apropriada crítica e filosófica resposta: "Nesta proporção, logo haverá dois físicos para cada pessoa viva!"). Esta extrapolação quântica é frequentemente citada e, no que diz respeito às várias "explosões" (informação, população, conhecimento, físicos e assim por diante), ela sugere que tal salto em quantidade implica um salto correspondente em qualidade. Seu objetivo, entretanto, permanece em reforçar a crença na disjunção entre a cultura científica e tecnológica e as culturas anteriores.

Associada a esta crença existe outra, neste caso, frequentemente mantida no nível dos especialistas. É a crença de que o fator crucial para criar tal disjunção é a ciência, particularmente em sua forma teórica. No âmbito mais restrito das comunidades da filosofia da ciência, dentre muitos cientistas, e mesmo dentre alguns historiadores, a crença dominante é a de que a tecnologia contemporânea é resultado da ciência, seja cronologicamente ou, mais comumente, devido à dependência da aplicação da teoria.

A relação entre ciência e tecnologia tem sido frequentemente a questão central nos círculos norte-americanos e europeus envolvidos com reflexões sobre a tecnologia. A visão dominante continua sendo a de que a tecnologia é ciência aplicada. E também que tais tecnologias são fortemente diferenciadas do trabalho manual do artesão ou das tecnologias artesanais do passado. 
No entanto, essa visão dominante vem gradativamente sendo contestada. Ao menos, ela é agora posta em questão. Qual é a relação entre ciência e tecnologia? E quais são as implicações destas relações tanto para casos especiais do conhecimento científico e, mais amplamente, para a gama completa de nossas atividades do saber?

Um segundo conjunto de questões, igualmente importante, orbita em torno do questionamento de as tecnologias serem ou não neutras. Seriam as tecnologias meras coisas que, como uma matéria inerte, não fazem nada por si mesmas? $\mathrm{Ou}$ as tecnologias afetam a forma como agimos, percebemos e entendemos? No senso comum, a crença de que tecnologias são meros artefatos-em-si é algumas vezes demonstrada em adesivos de automóveis: “Armas não matam pessoas, pessoas matam pessoas". Mas tal crença pode também tomar forma em discussões especializadas nas quais se afirma que as tecnologias não fazem nada; trata-se apenas da forma como elas são utilizadas.

Por exemplo, debates em torno do desenvolvimento tecnológico podem tomar forma a partir de um argumento entre aqueles que adotam a posição do determinismo social e aqueles que tomam a posição do determinismo tecnológico. Cientistas sociais frequentemente adotam de alguma forma a primeira posição, argumentando em favor de que o realmente importante no desenvolvimento tecnológico é o conjunto de decisões tomado pela elite dominante. Tecnologias, sob esta perspectiva, são resultantes de tais decisões (neste caso, o substituto da elite dominante para a teoria superior do argumento anterior da ciência/tecnologia) e a tecnologia é o resultado. Sob a perspectiva dos deterministas sociais, as tecnologias particulares usualmente permanecem como fatores atuando num plano secundário contra os quais os conflitos sociais, humanos e políticos tomam forma.

Um bom exemplo desta posição pode ser ilustrado pelo desenvolvimento da Ceifadeira McCormick. A ceifadeira é uma tecnologia que substituiu as foices de mão de um grande número de trabalhadores de fazendas. Sua lâmina cortava uma ampla quantidade de trigo e juntava este trigo em feixes. A lâmina era guiada mecanicamente por um complexo grupo de engrenagens que, inicialmente, eram feitas por habilidosos artesãos que produziam os moldes para a fundição, fundiam e acertavam o acabamento dos produtos irregulares.

Administradores, entretanto, logo consideraram os custos laborais demandados pelos artesãos como sendo muito caros. Então, uma nova técnica que dividia o processo em fases individuais foi desenvolvida, de forma que qualquer 
pessoa, sem nenhuma habilidade, poderia aprender alguma dessas fases do processo e praticá-la. Essa era uma prática desprezível, típica do século XIX, projetada e empregada amplamente para desqualificar os sindicatos nascentes.

$\mathrm{O}$ resultado foi muito relevante para qualquer imperativo tecnológico em relação à eficiência e ao custo. A produção de engrenagens por tais processos de fabricação sem especialização eram igualmente mais lentos e mais caros que o processo artesanal empregado anteriormente, tornando, assim, as ceifadeiras mais caras. Essa prática de produção-administrativa logrou um êxito: a eliminação dos sindicatos. Depois a fábrica McCormick retomou a sua antiga forma de produção empregando novos artesãos treinados.

Na medida em que a análise é socialmente determinista, alguém pode simplesmente notar que o processo e o produto da tecnologia ocupam um papel secundário no contexto da controvérsia entre administração/trabalho e, em última análise, quaisquer que sejam as tecnologias envolvidas fazem pouca diferença para o caso em si mesmo. Tal perspectiva simplesmente não trata com as tecnologias per se. Os efeitos funcionais são a interpretação da tecnologia como sendo neutra.

O determinismo tecnológico, por outro lado, encontra no desenvolvimento da tecnologia em si mesma toda uma fonte de possibilidades que determinam as futuras direções para a sociedade. Um bom exemplo é encontrado na reformulação de James Burke dos trabalhos iniciais de Lynn White sobre a tecnologia medieval. ${ }^{2}$ Ambos, Burke e White, viram no desenvolvimento do estribo uma conjuntura tecnológica crucial que afetou o desenvolvimento social da baixa Europa Medieval. Assim que o estribo foi inventado ou descoberto (ele pode ter sido emprestado, como muito da tecnologia medieval foi, das fontes orientais), um novo estilo de montaria tornou-se possível. Um guerreiro, em vez de usar sua lança para atacar um soldado com uma punhalada, podia agora atacar com velocidade, usando o poder do cavalo para empalar o inimigo. Todo um conjunto de mudanças poderia ocorrer e, de fato, aconteceram: as lanças mudaram de forma, passaram a ter uma travessa ou um nó para evitar que cravassem muito fundo nas vítimas e assim fosse difícil retirá-las. O tampão ou a travessa

2 Cf. James Burke, Connections. Boston: Little, Brown and Co., 1978 e Lynn White, Jr., Medieval and Technology and Social Change. Oxford: Oxford University Press, 1962. O primeiro popularizado, o segundo segue um conjunto de conexões históricas usualmente acidentais ao longo da histórica da tecnologia Ocidental em uma série de documentários na televisão pública. Eu devo utilizar algumas vezes ilustrações a partir de documentários e fontes de áudio amplamente disponíveis para servirem como elementos ilustrativos sobre contextos familiares. Documentários de alta qualidade são, de fato, uma parte essencial do modo corrente para a popularização da ciência e serve para ilustrar muito tal investigação. 
e a faixa colorida (que depois se tornaria individualizada para indicar o proprietário) foram inventadas. $\mathrm{O}$ selim tornou-se mais longo e foi equipado com um apoiador para a lança. Depois veio a armadura, a criação de cavalos maiores, e a emergência de uma cavalaria de elite (knights) e os custos mais altos envolvidos até que tudo resultasse nos caros e bem armados "tanques" medievais. Mais tarde, outra tecnologia, o arco longo, que servia como "artilharia” de longo alcance e o qual foi capaz ainda de perfurar armaduras, decretou o fim da combinação do cavaleiro pesado. ${ }^{3}$

Aqui, claramente, a tecnologia ocupou uma posição de primeiro plano, e é igualmente claro que a tecnologia não é central em relação a qualquer ação ou efeito. Mas há a sugestão de que, uma vez inventada, as tecnologias simplesmente sigam uma linha de desenvolvimento quase sem contexto, por assim dizer.

Em um extremo ainda maior do debate neutralidade/parcialidade, existem aqueles que, além de sustentar que as tecnologias não são neutras, defendem também que uma vez criada e inserida, a tecnologia (frequentemente descrita com T maiúsculo: Tecnologia) assume uma vida própria e se torna um autonomous. Os anos 1960 e 1970 deram popularidade a uma larga série de livros distópicos que argumentavam que a tecnologia havia superado o controle humano e, como no mito de Frankenstein, havia escapado. Dois dos mais amplamente lidos foram O Homem Unidimensional (One Dimensional Man), de Hebert Marcuse, e A Sociedade Tecnológica (The Technological Society), de Jacques Ellul. Ambos argumentavam no sentido de que a tecnologia era equipada com certas técnicas calculistas ("racionais") que, por sua vez, se tornavam não apenas dominantes, mas totais, fazendo, assim, a tecnologia como sendo a cultura absoluta. Ellul, indo além, e em companhia de muitos outros escritores, contrastava este meio social cultural com o meio social prévio, o qual ele caracterizava como sendo o da natureza. "Técnica se tornou o novo e específico meio social no qual se requer que o homem exista, meio o qual suplantou o antigo meio social, a saber, o da natureza."4

Com esta interpretação de tecnologia, surge outra crença popular: a de que a tecnologia, por ser produzida, é artificial e o artificial é para ser contrastado com o natural. Tal crença pode tomar uma forma muito popular, por exemplo, desde a prática de evitar comidas com aditivos de qualquer espécie até o uso

\footnotetext{
3 BURKE, 1978, p. 52-54.

4 ELLUL, Jacques. The Technological order: Proceedings of the Encyclopedia Britannica Conference, ed. Carl E. Stones, Wayne: Wayne Sate University Press, 1963, p. 10.
} 
apenas de fibras puramente "naturais" no vestuário. Ou toma uma forma sofisticada nos argumentos dos filósofos como aqueles que são comumente feitos por Hans Jonas sobre o modo como as tecnologias afetam até mesmo a essência da humanidade. Jonas argumenta que a inclinação para se buscar poder sobre a natureza feita para a "estreiteza que está pronta a sacrificar o resto da natureza para as pretensas necessidades (do homem), (e isto) pode apenas resultar na desumanização do homem, na atrofia de sua essência, mesmo no caso fortuito da sobrevivência biológica." ${ }^{5} \mathrm{~A}$ implicação disto é que a tecnologia, por estar inserida entre os humanos e a natureza, pode até mudar a essência da humanidade (ou aquilo que já foi a "natureza humana").

As interpretações distópicas da tecnologia foram populares nas duas últimas décadas, mas as utópicas também foram no século passado. Algumas foram tão longe como no caso de exaltar as propriedades estéticas das indústrias poluidoras cuja fumaça ajudava a criar um pôr do sol mais bonito. Os utópicos poderiam, então, ter sido denominados de globalistas na esperança. Ciência-tecnologia, corretamente aplicada e desenvolvida, acredita-se, pode eventualmente resolver mais, se não todos, os problemas pessoais e sociais humanos. Certamente os maiores como a pobreza, o crime, as doenças, as pestes e aqueles que poderiam ser eliminados de uma vez por todas. Hoje alguém raramente se encontra tal como um utópico globalista. Mas o que pode ser chamado especificamente ou simplesmente sistema utópico continua abundante em várias crenças na solução tecnológica.

Recentemente, os principais candidatos para a utopia da solução tecnológica têm sido os "fundamentalistas" da inteligência artificial (AI). Tal como Hubert Dreyfus sarcasticamente apontou em seu What Computers Can't Do (O que os Computadores Não podem Fazer), estes apologistas têm sido rápidos em alimentar a pauta dos jornalistas. Em 1970, a revista Life alegava, nas mesmas bases apresentadas pelos apologistas da inteligência artificial, que já existiam computadores que "viam", "compreendiam", "aprendiam" e "pensavam". E "distintos cientistas da computação eram citados como prevendo que de 3 a 15 anos 'nós teremos uma máquina com a inteligência completa de um ser humano médio... e em poucos meses (depois disso), tais máquinas estariam no nível dos gênios."'6 Um bom resultado da revolução dos computadores domésticos é que computadores agora são muito mais familiares a um amplo conjunto de

5 JONAS, Hans. "Responsibility Today: The Ethics of an endangered Future," Social Research 43, 1976, p. 84. 6 Citado em Hubert Dreyfus, What Computers Can't Do. New York: Harper and Row Publishers, 1972, p. xxviii. 
usuários, com o resultado predicável de que o uso ordinário fez da mística destes "experts" muito menos reveladora; hoje a comunidade AI, embora ainda não povoada o suficiente por fundamentalistas AI para manter a mitologia viva, tem se tornado predominantemente mais modesta sobre esses processos de modelagem metafóricos parecerem promissores.

Mais seriamente, entretanto, o sistema utópico único agora tem levado em conta muito da atividade envolvendo a biônica nas ciências da saúde. Desde os claramente úteis utensílios protéticos e os experimentos correlatos (minirradares para as máquinas de "leitura" cegas e brutas; membros artificiais melhorados por computador para os paralisados, etc.), os experimentos médicos de tecnologia avançada tem se transformado em biônicos internos (rim artificial, coração artificial, embora o cérebro artificial ainda pareça estar muito distante!). Incorporada em tais experimentos, está clara a indicação das crenças sobre as soluções tecnológicas vis-à-vis com as relações humano-tecnologia. Qual é o alcance de tais relações? E quais estruturas experienciais elas apresentam?

Mais sério ainda são os atuais experimentos sobre a solução tecnológica que podem presumivelmente proteger países contra um ataque nuclear: Star Wars. Aqui as implicações econômicas e políticas são genuinamente impressionantes e, se promulgadas, empenham as futuras gerações a um questionável sistema político-tecnológico. Novamente, as suposições contidas neste movimento político em relação à solução megatecnológica são basicamente utópicas.

Um terceiro conjunto de questões existenciais envolvendo o futuro. O que o alto desenvolvimento tecnológico anuncia para o futuro de nossa espécie? Os sensos comum e especializado apresentam avaliações variadas desde as distópicas até as utópicas. Se o conjunto das tecnologias poderia ser apreendido, e mesmo a questão sobre a possibilidade de tal avaliação é difícil, tal conjunto indicaria um fenômeno Frankenstein tal como os distópicos defendem? Ou o futuro se tornará estável, e o corrente conjunto de problemas, que emerge devido ao passado do progresso científico e tecnológico, será solucionado? Na medida em que existem desde épocas anteriores, as catástrofes da natureza têm sido muitas vezes substituídas por ameaças que são muito mais relacionadas à própria atividade humana, isto é, à atividade tecnológica humana. Humanos-com-tecnologias têm claramente se tornado uma força global. Efeitos oceânicos e atmosféricos causados pelas práticas industriais são indicadores claros deste fato. Assim, muitas vezes a questão sobre o futuro assume a forma da questão sobre o controle da tecnologia. $\mathrm{O}$ estrito fato de que a questão dominante do século 
XIX sobre o controle da natureza é agora colocada lado a lado com a questão do controle da tecnologia em si mesma é sugestiva desta mudança na sensibilidade.

A tecnologia pode ser controlada? Ou ela se tornou autônoma e fora de controle? Se controlável, como ela deve ser controlada? E sob quais formas de autoridade? Questões sobre o futuro contêm nossos medos e esperanças. A outra forma necessária que este conjunto de questões toma é se existe alguma trajetória única e esmagadora para a tecnologia como um todo. Existirá uma única e universal civilização tecnológica? Se sim, ela será democrática ou totalitária? Centralizada ou descentralizada? Ela possuirá variações ou será monolítica? A literatura que opera com tais questões é bastante pautada na nossa cinematografia de ficção científica, bem como em toda uma variedade de livros sobre os presumíveis efeitos da tecnologia.

Não é preciso voltar à literatura especulativa para ter em conta as direções divergentes presentes. Nos debates em torno da produção nuclear de energia, um medo tem sido o de que tecnologias avançadas contenham uma determinação frente à centralização e à autoridade hierárquica. Igualmente a segurança (de produtos nucleares utilizáveis por terroristas, à produção de subprodutos radioativos por gerações) e as necessidades de segurança parecem clamar por estruturas secretas de autoridade altamente controladas. Num nível mais comum, a veloz introdução dos computadores nos lares e no comércio nos tornou cientes igualmente do grande potencial para a comunicação e para as trocas (linhas diretas com nossos bancos, trabalhar em casas e estar em contato com o escritório, etc.) e das ameaças de invasão de privacidade e de maciças avarias e erros. Muitos de nós temos sido pegos em um problema persistente relativo ao faturamento das empresas de computadores. Todos nós recebemos novas ondas de spams devido à disseminação de listas de e-mails pelos anunciantes. Em uma escala mundial, as culturas tradicionais estão a desaparecer rapidamente agora. Estaria esta marcha da tecnologia contemporânea a determinar o fim desta variedade de formas de vida humanas? Atualmente os antropólogos estão correndo atrás das culturas previamente isoladas para registrar aquilo que, muitos acreditam, desaparecerá momentos antes de sua absorção às culturas de tecnologia avançada de origem ocidental.

Ainda mais predominantes são as amplas questões sobre se a nossa geração ou a próxima vai submeter-se ou sobreviver a um holocausto nuclear, ou se os efeitos em longo prazo das tecnologias industriais produzirão alguns irreversíveis 
e possivelmente deletérios efeitos climáticos, fazendo da vida que nós conhecemos diferente, mais difícil ou até mesmo insuportável.

Essas questões e as respostas conhecidas igualmente do senso comum e dos especialistas parecem apontar para uma séria crítica filosófica. Ainda que filósofos, particularmente aqueles na América do Norte, têm sido poucos e tardios em fazer da tecnologia o tema central de sua investigação. De fato, o que vem agora tardiamente tornando-se conhecido como filosofia da tecnologia apenas recentemente apareceu em cena. Existem razões para esta entrada tardia, mas, por agora, a pura magnitude igualmente no escopo e na profundidade destas questões deve ser impressionante o suficiente para gerar até mesmo no filósofo mais ambicioso uma pausa. Ainda que seja precisamente o objetivo deste livro adentrar na arena a qual possa agora ser denominada de filosofia da tecnologia, deve-se entender desde o início que a tarefa da filosofia, não importa o quão vasta ou profunda, é também limitada. O filósofo não pode fornecer respostas tal como fórmulas às questões colocadas e nem existe qualquer probabilidade de tais respostas serem simples. Existem duas coisas que um filósofo pode fazer: fornecer uma perspectiva a partir da qual se pode vislumbrar o terreno, neste caso, o fenômeno da tecnologia, ou melhor, o fenômeno das relações humano-tecnologia; fornecer um quadro ou "paradigma" para o entendimento. Esses objetivos filosóficos gerais serão realizados aqui.

A primeira destas tarefas é estabelecer a perspectiva a partir da qual se vislumbrará o vasto e complexo terreno da tecnologia e de seu contexto humano. Eu sugiro, de início, que parte do que a realização desta perspectiva demanda é uma medida certa de distanciamento, de modo que a singularidade e mesmo a peculiaridade da nossa cultura tecnológica possam, assim, serem avistadas. $\mathrm{Na}$ medida em que o pensamento crítico é como enxergar igualmente o que está muito perto (a ponta do nosso nariz) e o que está muito longe (para além do horizonte), ele não é simplesmente e claramente discernível.

As perspectivas filosóficas comuns ou dominantes frequentemente podem ser chamadas de lucrecianas. No clássico De Rerum Natura, Lucrécio descreve a perspectiva filosófica como sendo análoga à de uma Torre Alta (e, em algumas traduções, Torre de Marfim), a partir da qual as aflições e os atos humanos parecem distantes e triviais, como no reino das formigas, sob o ponto de vista humano. Nesta metáfora de distanciamento em busca de objetividade, se trai igualmente as preferências por uma posição fixa e distante. Numa analogia contemporânea, poderíamos optar por uma visão de satélite. Como atualmente nós 
começamos a fazer "medições de toda a terra" via satélite, assim o filósofo pode preferir esta longa distância.

Ainda neste caso de análise da cultura tecnológica, há algo radicalmente errado com esta escolha. Não mais do que uma pretensa visão marciana sobre nós mesmos, poderemos nos desperceber de certa proximidade oculta pela metáfora do satélite. Ao contrário, habitar o satélite seria uma metáfora melhor para ilustrar o enredamento, o invólucro que temos em nossa tecnoesfera. $\mathrm{O}$ veículo espacial é apenas um exemplo extremo de um casulo tecnológico que nos fornece um suporte à vida, um ambiente construído, uma camada hermética, através e por meio da qual nós estaríamos formulando nossas imagens. Longe de nos dar distanciamento sobre o fenômeno, terminaríamos simplesmente tomando-os como um dado adquirido.

Por esta e por outras razões que apontarei depois, eu prefiro usar uma metáfora mais kierkegaardiana como ponto de partida a fim de estabelecer esta perspectiva. Em Temor e Tremor, no contexto da descrição da inevitabilidade da decisão, Kierkegaard faz uma imagem de nós como capitães de navios no mar, navegando. A pessoa ao leme já está em movimento; e fazer acontecer ou não fazer acontecer já é igualmente tomar uma decisão. Eu modificarei esta imagem por observar que o ângulo desta perspectiva é basicamente marítimo. O navegador, exatamente no meio do mar, quando o barco e o mar encontram-se igualmente em movimento, deve seguir um rumo, encontrar uma direção e situar a si próprio e a sua destinação. Essa perspectiva ocorre numa dinâmica e situação fugidia e é bastante realística, ainda que tal situação seja normal para o navegador.

A perspectiva marítima é suficientemente autoconsciente de estar em meio daquilo que está acontecendo, mas o problema navegacional é localizar os pontos de referência através de algumas variações do meio. Aqui há, pelo menos, uma boa lição que pode ser aprendida a partir também das viagens espaciais. Astronautas que vivem junto aos vários casulos que nós projetamos encontram-se sem peso. O seu ponto de referência terrestre, a gravidade normalmente relacionada à nossa postura ereta, foi perdido. Eles devem escolher um ponto de referência a partir do qual vão se movimentar. Frequentemente eles farão isso arbitrariamente: "Esta maçaneta ali vai significar 'para cima', e aquela alavanca lá, 'para baixo"'. Em resumo, eles devem reaprender um tipo de mobilidade corporal em um novo quadro de referências e, desta forma, eles inventam um novo tipo de navegação corporal. Similarmente, dentre os variados estilos de navegação, alguns pontos de referência e alguns conjuntos de variações devem 
ser constituídos para se atingir as localizações relativísticas cruciais para encontrarmos o nosso caminho.

Embora eu deva desenvolver em breve tais sugestões de uma maneira mais técnica e precisa, a instauração da investigação pode ser feita, bem informalmente, com um dispositivo muito familiar para os filósofos. Um mito ou conto contemporâneo servirá, não muito diferente da estória da Caverna inventada por Platão, para pontuar tal teoria epistemológica, para demonstrar aquilo que deve ser buscado. Nesse caso, entretanto, vou elaborar, de maneira bastante proposital, a partir daquele que seja talvez o mito mais familiar em nossas tradições, o mito que apresenta nossos apetites de inocência e nossas preocupações sobre deixar para trás o paraíso, a história do Jardim do Éden. 


\section{1 \\ Do JARDim À Terra}

$\mathrm{Na}$ Introdução, uma pergunta tácita, mas que não chegou a ser feita, era: Os humanos podem viver sem tecnologias? Claramente, em qualquer sentido empírico ou histórico, eles de fato não podem. Não existem povos conhecidos, em tempos pré-históricos ou históricos, que não possuíssem tecnologias num sentido mínimo, ainda que ainda desejemos dizer que eles podem, efetivamente, viver assim no limite possível da imaginação. Um salto imaginativo pode ser feito apenas para ilustrar tal forma de vida, um salto que servirá como uma finalidade heurística recorrente.

Devemos, no entanto, desde o princípio, estar cientes da característica imaginativa e até mesmo quase mítica de tal exercício. Desde que encaremos isto a partir da posição familiar e engajada que realmente ocupamos dentro da nossa forma de vida tecnologicamente mais saturada, nós mesmos podemos não ter consciência de quão profundamente estamos enredados, mesmo ao nível perceptivo, nesta forma de vida. Voltemos ao nosso alpinista com os pítons e mosquetões e poderemos notar que a própria percepção que ele ou ela tem da montanha já possui uma longa e distinta história que pressupõe aspectos da cultura tecnológica.

Na Idade Média, por exemplo, montanhas eram usualmente percebidas como sendo ameaçadoras, sinistras, perigosas e existe até mesmo na história da arte alguma evidência de que elas raramente eram tomadas como sendo belas. 
Até o século XVIII, por exemplo, a região do pico de Derbyshire na Inglaterra era considerado selvagem e impróprio para os olhos humanos. Em 1861, o poeta Charles Cotton descreveu-o como sendo um "território tão deformado" que poderia ser considerado como a "pudenda da Natureza”. Viajantes naqueles dias eram aconselhados a manter as cortinas das janelas de suas carruagens fechadas enquanto atravessavam a região para não ficarem chocados por sua feiura e selvageria. ${ }^{1}$

Ainda nos idos do século XIX, as montanhas se tornaram misticamente belas (nas grandes pinturas de paisagens da Europa), e uma das modas passageiras era a de espectadores de montanhas irem olhar para elas com molduras para enquadrá-las esteticamente. Essa inversão é destacada por René Dubos como sendo, em parte, uma reação ao aumento da maquinaria em si. "O movimento europeu pró-vida selvagem adquiriu mais dinâmica no século XIX a partir da reação contra as brutalidades da Revolução Industrial."2 Igualmente, no Japão, os alpes japoneses eram considerados sinistros e como sendo a morada dos demônios antes dos aventureiros europeus começarem a explorá-los e escalá-los; eles se tornaram então o espaço da recreação para a desenvolvida indústria do montanhismo do Japão. O alpinista não desconhece o perigo, no entanto sublima a percepção do perigo para a do desafio, uma vez que alguns picos que estavam além do limite da escalada agora são possíveis de serem alcançados graças às tecnologias ligadas ao alpinismo. Em uma observação mais tecnologicamente entrelaçada, podemos notar que montanhas atualmente são regularmente "conquistadas” por estradas, trilhos e, especificamente, por sobrevoos de aviões. A própria experiência que temos das montanhas foi transformada.

E é apenas por esta razão que o novo Éden deve ser imaginativo, pois não podemos dizer com profundidade o que tal Jardim do Éden poderia significar para nossa experiência. Ele continua uma estória, uma variação imaginativa. Imagine um Novo Éden, um novo conto sobre as origens, no qual um novo Adão e uma nova Eva, como os antigos, aparecem primeiro, nus e colocados no Jardim não tecnológico. Hoje a narrativa de tal fábula deve levar em conta as armadilhas familiares ao nosso próprio contexto, talvez o contexto do bem-informado espectador de documentários, em si mesmo o produto de nossa cientificamente permeada sociedade. A busca pelo novo Éden hoje será guiada

1 DUBOS, René. The Wooing of Earth. New York: Charles Scribner's Sons, 1980, p.14.

2 DUBOS, 1980, p. 15. 
por familiaridade com as disciplinas da antropologia, ecologia, comportamento animal, geografia e áreas afins.

Se fôssemos encontrar tias antropoides, saberíamos de antemão quais os traços de humanidade que deveríamos procurar. O novo Adão e a nova Eva, por exemplo, deveriam claramente ser usuários de linguagem, mas eles deveriam obviamente estar restritos à fala oral e aos comportamentos associados a ela (gestos, linguagens corporais, etc.), embora eles possam muito bem ter também desenvolvido sua expressividade em forma de canções, poesia e dança, igualmente no sentido estético e no religioso. Mas nenhuma dessas atividades poderia envolver artefatos em alguma técnica ativa. (Eu devo frequentemente usar o termo "técnica" para sugerir a ação humana que emprega artefatos para obter alguma vantagem sobre o meio-ambiente.) Assim, a escrita, os instrumentos musicais, as máscaras, etc. não poderiam ser empregados.

Similarmente, humanos no Paraíso poderiam ter acasalamentos complexos e padrões sexuais que preservariam a estabilidade das famílias e das linhas de parentesco. Eles poderiam ter tradições sobre casamentos, múltiplas variantes, com as quais os antropologistas estão familiarizados (patriarcal, matriarcal, monogamia, poligamia, etc.), embora isso fosse transmitido oralmente e por meio das histórias dramáticas já sugeridas. Mas não poderia haver registros, calendários ou marcadores para os movimentos dos corpos celestes e assim por diante.

Esta existência nua e face a face, no entanto, também necessariamente impõe restrições ecológicas sobre como tal Paraíso deveria ser. Porque cultura material (tecnologia em seu sentido mais amplo) não poderia existir; nosso casal primitivo deveria estar numa região tropical onde temperaturas extremas não poderiam causar hipo ou hipertermia (sem fogo, sem roupas, sem habitações construídas). O suprimento de comida deveria ser constante e de fácil acesso. Num ambiente tropical, deve existir frutas, plantas comestíveis, rãs facilmente apanháveis, peixes, vermes e assim por diante. Mas o nosso casal não tecnológico não deve possuir tecnologias de armazenamento (cestas, potes) ou tecnologias de caça (redes, lanças, anzóis) ou mesmo tecnologias de cozimento (fogo e preparação de comidas). Nem devemos esquecer que nosso paraíso tropical deve ser localizado em algum lugar onde exista a ausência de grandes predadores que pudessem colocar os humanos em perigo (sem armas seja para a defesa ou para o ataque).

O que este exercício imaginativo inicial revela é que seria possível para os humanos viverem não tecnologicamente, tal como nesta possibilidade abstrata, 
mas apenas sob as condições de que tal meio ambiente fosse este paraíso, isolado, protegido e estável. O preço para tal existência não tecnológica é estar isolado. Aqui estaria o "meio da natureza" em sua forma mais pura. Mas não existe tal forma de vida histórico-empírica humana porque, muito antes do que podemos lembrar, os humanos saíram de todos os paraísos para herdarem a Terra.

O propósito deste exercício, no entanto, não é o de induzir à nostalgia do Paraíso ou o de romantizar uma suposta existência "natural". Ao contrário, o objetivo aqui é começar a mensurar sobre a diversidade de variações nas quais os humanos moldam suas formas de vida. Ao iniciar com esta variação abstrata, existe ao menos a sugestão que pode ser seguida no que diz respeito às atuais aproximações das situações face a face descritas. Em regiões tropicais, existem ainda certas culturas tecnologicamente minimalistas.

Os notáveis Tasaday, uma cultura da Idade da Pedra primeiramente reportada em 1972 no interior de Mindanao, são um bom exemplo disto. Os Tasaday vivem em cavernas em meio a um rico meio ambiente que prove a eles uma existência estável, enquanto básica. No entanto, eles são quase não tecnológicos, apesar do minimalismo que caracteriza a sua forma de vida. Notemos alguns aspectos básicos de sua existência:

Sua dieta consiste de girinos, pequenos caranguejos, rãs, frutas em abundância e certa matéria vegetal, tal como palmitos e outros caules comestíveis. Porém, a preparação da comida é em si uma técnica que envolve importantes, ainda que básicas, tecnologias. Eles fazem fogo (por meio do método de fricção com dois gravetos, uma técnica que demanda artefatos), cozinham certas comidas (envolvem os girinos em folhas largas e panificação) e empregam outras preparações culinárias visando um fim para os alimentos (o cozimento) materialmente diferente de seu estado natural (cru).

- O vestuário é genuinamente mínimo, mas os adultos vestem tangas de matéria vegetal.

- O controle de temperatura é propositadamente empregado (fogos nas cavernas tanto para cozinhar quanto para afastar o ar frio da noite).

- Enquanto não existe um arsenal sofisticado, os Tasaday têm um machado de pedra arredondado que não é usado para matar as presas, mas para quebrar nozes e para partir gêneros alimentícios mais rígidos.

- Numa escala mais ampla, eles possuem armadilhas para cervos, comportas para a água e métodos para garantir o amido extraído das palmeiras, todos envolvendo técnicas e tecnologias bem complicadas. 
Este povo, primeiramente encontrado em 1972 sob os auspícios de uma exploração da National Geographic, aparentava ser de um anacronismo tal, que as suspeitas de que eles foram "plantados" ali logo recaíram sobre o governo das Filipinas (o que foi negado posteriormente pela National Geographic). No entanto, a questão que podemos afirmar aqui: se os Tasaday já tinham abandonado o seu "Paraíso", se há muito tempo já haviam abandonado o modo de existência não tecnológica e herdado sua terra local, com ao menos tecnologias mínimas, então eles fazem partem dos mesmos movimentos que levaram os seres humanos para os cantos mais extremos da Terra, atingindo até mesmo as regiões do Ártico. Os inuítes (esquimós) desenvolveram uma tecnologia basicamente da Idade da Pedra em prol de uma grande habilidade:

- Sua dieta é radicalmente diferente daquela dos Tasaday. Muito mais carne (baleia, foca, peixe, mais gordura para suportar o frio) é comida, junto a alguns alimentos de origem vegetal sazonais.

- Para obter esta dieta, uma cultura de caçadores teve que ser desenvolvida com tecnologias muito sofisticadas derivadas de matéria animal. Tendões, ossos, pele que serve a uma multiplicidade de propósitos que vão desde armas (arpão, arco e flecha, lanças) a embarcações (os sofisticados caiaques, umiaks e outros barcos, alguns dos quais chegaram com passageiros vivos na Irlanda Medieval após serem carregados ao longo do Atlântico por tempestades).

- A pele dos animais foi a habitação disponível nos padrões migratórios e serviu como barraca para o clima quente e o iglu de neve para o inverno (completado com lamparinas à base de óleo de baleia, janelas de gelo para a luz entrar e uma temperatura quente o suficiente para ficar nele sem roupas).

Existem ainda adaptações similarmente genais, com tecnologias simples e mínimas, no deserto, na floresta e nas culturas das estepes. Entretanto, todas ilustram que, ao utilizarem tecnologias, os humanos deixam o Paraíso não tecnológico para herdar a Terra. O preço deste legado é ter de utilizar uma tecnologia. O propósito aqui, no entanto, é mensurar. Se as variantes das relações humano-tecnologia citadas devem ser consideradas minimalistas, então há familiaridades muito próximas entre os humanos e suas tecnologias.

Mensurar é interpretar. Humanos são autointérpretes, mas não necessariamente em termos de uma autorreferência egocêntrica. Frequentemente eles mensuram com base e em relação a outros reinos de seres. Por exemplo, o reino animal quase sempre desempenha um papel neste processo. $\mathrm{O}$ nosso próprio mito do Éden bíblico, por exemplo, claramente coloca os humanos acima de 
todos os animais e considera a distância entre humanos e animais como sendo imensa. A primeira ordem do Gênesis é: "E disse Deus: 'Façamos o homem à nossa imagem, conforme a nossa semelhança; e que ele domine sobre os peixes do mar, e sobre as aves dos céus, e sobre o gado, e sobre toda a terra, e sobre todo o réptil que se move sobre a terra...' E Deus disse a eles: 'Frutificai e multiplicai-vos, e enchei a terra, e sujeitai-a." E os humanos não têm sido relapsos em seguir esta instrução. Como sendo a crença dominante em nossa cultura, esta relação próxima com Deus e mais distante do mundo animal tem prevalecido.

Existe atualmente certa quantidade de reavaliações ocorrendo, que, de vez em quando, sugerem a diminuição do distanciamento entre nós e os animais mais próximos aos humanos. Enquanto o propósito aqui não é ainda o de julgar tal reavaliação, a emergência daquilo que eu chamarei prototecnologias no âmbito do reino animal também é instrutivo heuristicamente para a tarefa de mensurar.

Jane Goodall, em seus estudos sobre chimpanzés, documentou que eles usam e formatam varetas para extrair cupins de seus ninhos e que ocasionalmente usam bastões para matar pequenos antílopes, assim como frequentemente usam galhos com largas folhas para se abrigarem da chuva. Todo esse comportamento para o emprego de ferramentas segue claramente a mesma trajetória do uso que os humanos fazem de ferramentas, mesmo que os objetos utilizados pelos chimpanzés não sejam mais manuseados posteriormente ou mantidos em posse do usuário.

Mesmo em menor escala, tentilhões descobertos por Darwin nas Ilhas Galápagos, os quais utilizam espinhos, o sofisticado sistema de controle de temperatura de insetos sociais tais como os cupins e as técnicas de "agricultura" regularmente praticadas por formigas e outros insetos sociais, todas sugerem a realização de um tipo de prototecnologia. Essas relações próximas com a cultura tecnológica podem ser apontadas sem diminuir em nada a extensão e o nível do desenvolvimento tecnológico que ocorre amplamente apenas no domínio dos humanos em nosso planeta.

O mito do novo Éden coloca toda forma tecnológica em destaque em relação aos vários graus de proximidade a uma forma de vida altamente tecnológica. Se os animais possuem certas prototecnologias e se culturas tecnologicamente minimalistas tal como os Tasaday possuem relações distantes da nossa cultura maxitecnológica, eles já estão, no entanto, muito distantes da pureza abstrata do Paraíso não tecnológico. 
Mas nós deixamos o Paraíso totalmente para trás? Teríamos "memórias" que tomam forma de eventos limitados ou ocasiões nas quais nós experimentamos o face a face nu de nosso casal primário? Quem não deseja ou ocasionalmente se satisfaz no ato de nadar completamente nu, em ter relações sexuais íntimas numa cama feita de musgos na floresta, dar um mergulho na neve depois de um banho quente numa fonte mineral ou caminhar descalço sob a luz numa praia deserta?

Essas são percepções vivenciadas pelo corpo sem mediações ou, ao menos temporariamente, sem nenhuma mediação tecnológica que usualmente são mais normais. Essas são percepções corporais diretas sobre os outros e sobre o ambiente circundante.

Eu iniciei com uma lista deliberada de prazeres de relações face a face correndo o risco intencional de romantizar essas relações imediatas. Se deixados aqui apenas estes exemplos, a nostalgia da inocência se tornaria galopante. Assim, a lista deve ser contrabalançada por exemplos de relações face a face igualmente negativos.

Lembro de uma vez, no calor do verão de Kansas, capinando a aveia, de ter o vento soprado palhas sobre o meu peito sem camisa, causando uma coceira dolorosa. A variação não tecnológica que se pode estabelecer em estar nu entre a aveia é essa coceira-sendo-no-mundo.

Levando estas nossas variáveis, quente e fria ao extremo, cair num gêiser de água fervendo ou na água quase congelada de um lago nos remetem ao lado negativo, até mesmo mortal, dessas variações do face a face nu.

Toda a variedade dessas relações face a face pode ser tanto negativa quanto positiva. O que é essencial é isolar a dimensão direta, mediada não tecnologicamente dessas experiências. Tal dimensão será necessária para contrastar precisamente com aquelas experiências que são tecnologicamente mediadas.

$\mathrm{O}$ isolamento da diferença entre o mediado tecnologicamente e as experiências não tecnológicas do mundo vão formatar a parte inicial da investigação. O problema sempre presente nesta ideia é que tal diferença quase sempre se confunde ou com a interpretação romântica ou antirromântica na maioria dos exames da tecnologia em face da vida humana.

A ânsia pela inocência que domina as interpretações mais românticas é muito antiga. A tradição rousseauniana do "bom selvagem" tem suas variantes que se estendem até mesmo nos recintos de algumas explorações iniciais e em certas interpretações antropológicas. Chegar à idade adulta em Samoa é sempre 
algo livre das tensões adolescentes tal como descreveu certa vez Margaret Mead, mas nós sabemos agora que a história de muitos habitantes das ilhas do Pacífico teve seu próprio lado sangrento. Eles eram, aparentemente, tão propensos a "bater cabeça" como qualquer outro, e as guerras intertribais podem ter sido motivadas por interesses exploratórios e para fins de ocupação de virtualmente todas as ilhas inabitadas do Pacífico um milênio antes de Leif Ericson ter chegado à Groelândia. Também hoje é conhecido o fato de que até dois terços dos nascidos vivos eram vítimas de um "controle de natalidade", executado às vezes por infanticídio, o que não encoraja a interpretação romântica daquilo que foi outrora uma crença mais comum sobre os paraísos do Pacífico.

Em anos mais recentes, não há muito tempo, a mesma busca pela inocência foi aplicada aos nossos parentes mais próximos, os primatas. Enquanto os gorilas podem permanecer basicamente vegetarianos em sua dieta, os estudos de Goodall sobre chimpanzés desiludiram outra expectativa de esperança por um comportamento melhor. Ela descobriu não apenas que ocasionalmente os chimpanzés comem carne (até mesmo usam bastões para matar veados), mas também que eles ocasionalmente matam uns aos outros, particularmente os jovens.

Mas o objetivo de ir até o outro extremo do espectro não é o de argumentar sobre alguma nova forma de pecado original. Nos mesmos debates envolvendo a inocência ou perversidade tanto de nossos pares humanos ou de nossos humanos-próximos, nossos parentes - os primatas, aqueles que agora creem no pecado original usualmente expõem algumas variáveis da imutabilidade da natureza humana cujos padrões podem ser antecipados sociobiologicamente no âmbito de algum domínio do comportamento animal. A variedade de comportamentos dentre os animais é, entretanto, muito diversa para fazer mais do que prover algum campo para uma seletividade presumida, que, por sua vez, é frequentemente usada para reforçar uma posição político-religiosa tomada pelo intérprete.

O que é necessário é uma estória radicalmente muito mais desmistificada sobre as estruturas e limites das possibilidades entre as relações humano-tecnologia e não tecnológicas com o ambiente, ou com o "mundo". Se esta avaliação essencialmente descritiva for considerada, o conto do Paraíso pode novamente ser usado como uma ideia-limite com o propósito de delimitar alguns daqueles aspectos da experiência humana que permanecem em certo sentido nas relações face a face com os outros e com o mundo.

Existe ainda um segundo senso limitado no qual nós deixamos o Paraíso místico para trás. Há diferentes graus nos quais nossas experiências do mundo 
não são mediadas tecnologicamente, ao menos no centro de nossas percepções e experiências corpóreas do mundo. Por exemplo, mesmo quando vestidos e no interior de alguma "máquina da vida", tal como os funcionalistas têm nomeado os prédios, a pessoa com visão e audição normais simplesmente ouve e vê o que é imediato. Em contraste, qualquer um usando lentes corretivas ou aparelhos auditivos claramente vê e escuta de forma mediada através da tecnologia. Ao nível do toque, primeiramente na dimensão da superfície, nós sempre podemos estar específica e imediatamente cientes do corpo circundante daquilo que tocamos. Em resumo, nossa vida sensorial, mesmo que a curta distância, ou fechada, mantém aquela sensação da percepção direta e da motilidade dos corpos no ambiente imediato. Como essa experiência corporal acional e perceptível difere das experiências mais específica e tecnologicamente mediadas, desempenhará um papel essencial na diferença inicial que eu estou tentando isolar para esta análise.

Tendo localizado uma vez este núcleo central da percepção, a experiência corpórea de um ambiente, será possível apontar igualmente para sua constância e seu alcance. Enquanto eu estou tendo a experiência de tudo, faço-o em formas de percepção corporal, e este é o caso dentro de quaisquer tecnologias que eu possa ocupar. Em um ambiente frio, eu poderia experimentar pelo tato o vento e o frio; porém, se eu tiver "escolhido" para mediar esse frio, vestindo roupa de baixo, eu agora substituo sentir o vento para sentir o calor daquilo que estou vestindo. Nesse caso, o "ambiente" é simplesmente levado para perto e ele passa a ter a textura de um dos muitos casulos humanos empregados em todas as situações não Paraíso. A tecnologia (vestuário), no entanto, transforma este ambiente imediatamente vivenciado; e é esta transformação que deve ser investigada.

O contato de percepção corporal direto com o ambiente conta, por um lado, com a experiência humana mediada não tecnologicamente/tecnologicamente que cria o foco para a entrada na análise das relações humano-tecnologia.

Se o contato perceptivo diretamente corporal com um ambiente, mesmo que limitado, é constante, ele possui o sentido de nossa existência do paraíso não tecnológico. No entanto, é preciso ter cuidado mesmo aqui, para que não pensemos que uma variação tão imaginativa simplesmente capte as nuances necessárias para fazer um contraste entre uma forma de vida tecnológica ou não tecnológica.

As formas de vida culturais, ou melhor, tecnologicamente culturais, as quais circunscrevem todas as nossas sociedades empíricas humanas, são também 
contextuais em termos de formas gerais. Virtualmente todas as atividades humanas implicam cultura material e, por sua vez, isto forma o contexto para nossas percepções mais amplas. Tome, como um caso extremo, o fenômeno da morte.

Os gnus devem ser usualmente entendidos como seres não tecnológicos, ao menos em seu habitat natural. Leões, nesta região, usualmente são predadores e frequentemente capturam as jovens crias dos gnus. A mãe gnu, algumas vezes em conjunto com outros de sua espécie, algumas vezes sozinha, defende seu filhote até que o leão consiga capturá-lo. E, então, geralmente, num rápido momento, a mãe foge e logo estará pastando novamente com o rebanho. Sem especulações muito profundas de como a vaca percebe a morte de seu bezerro, uma espécie de aura fatalista ou de aceitação rodeia esse comportamento. Contrariamente, o chimpanzé, tal como os observadores notaram, pode carregar um jovem morto por dias e inclusive entrar numa óbvia forma de depressão animal ou psicose depois da morte. No entanto, no fim, o jovem é simplesmente abandonado e a vida continua.

No caso dos humanos, no entanto, existem rituais fúnebres, e todos eles, em termos de cultura material, envolvem tecnologias. Até tempos recentes, além disso, era um lugar comum transcultural não apenas ter algumas práticas no que diz respeito ao cadáver, mas também incluir no túmulo uma variedade de artefatos ordinários representados e até mesmo outros seres vivos ou suas representações.

A descoberta no século XX de certas câmaras funerárias imperiais chinesas antigas revelou exércitos inteiros (em cerâmica) representados junto aos mais tradicionais utensílios para a alimentação, itens domésticos, animais de estimação e assim por diante. Locações funerárias neandertais frequentemente contêm roupas, armas, potes, etc. Morte, enquanto materializada nas práticas funerárias, pode bem ser considerada uma passagem. Contudo, longe de ser considerada uma passagem do totalmente familiar (mundano) para o totalmente estranho (não mundano ou supramundano), as práticas parecem evidenciar um tipo de continuidade material.

O que é levado na jornada é o que se usa na vida cotidiana e o que faz parte do círculo das experiências importantes. Isto inclui artefatos, particularmente aqueles que expressam o poder do indivíduo (armas são comuns, mas as joias também são, o que faz a pilhagem de túmulos ser tão tentadora). Algumas vezes até mesmo relações próximas ou seus substitutivos são enterrados. Foram incluídos, seja em pessoa ou em suas representações, outras pessoas que eram as companhias ou esposas ou servos do morto. O enterro de escravos vivos (Egito), 
sacrifício de escravos (Maias), enterro conjunto de esposas (Índia) e sacrifícios de donzelas escravas (Viking) eram muito comuns, bem como as representações de concubinas (Egito) para a viagem. Meu ponto aqui não é demonstrar o chauvinismo masculino extremo no passado (mesmo que os exemplos possam servir para este propósito), mas ilustrar o que pode ser chamado de fronteira variável sobre o que foi considerado junto ao poder, ou poder possessivo, do indivíduo. Em sociedades em que indivíduos são considerados reduzidos ou restritos aos seus autônomos, práticas funerárias raramente incluem mais do que poucos itens privados possuídos. O é, como o fora, a diferença no "corpo" efetivo do indivíduo que é exemplificado. O corpo físico permanece apenas o centro de alguma ampla extensão radiante, que se inclui junto aos paramentos dos artefatos favoritos e seres vivos que pertencem imediatamente a ele. Um comentário final antes de tomar um exemplo menos mórbido: esses enterros indicados anteriormente são de proeminentes, de pessoas poderosas junto às sociedades apontadas. Comuns raramente tinham os mesmos elaborados funerais. A distinção entre as classes é indicada aparentemente algumas vezes pelas práticas funerárias; por exemplo, agora é sabido que o enterro de indivíduos em posição fetal dentre os celtas não era necessariamente um sinal de alguma prática mais antiga. Ele ocorreu algumas vezes contemporaneamente em práticas funerárias mais comuns, diferenciando o status do indivíduo. Essa diferença, enquanto claramente "econômica" no sentido contemporâneo, foi talvez mais indicativa do conteúdo da extensão do "corpo político" do indivíduo assim tratado.

Em contraste às formas de comportamento animais não humanas frente à morte, práticas funerárias humanas implicam aspectos das relações humano-tecnologia. Enquanto eu devo sugerir que a experiência de, e a relação com, artefatos não apresenta uma linha claramente traçada e distinta de demarcação entre humano e animal; entretanto, de fato, a ambiguidade essencial da tecnologia é evidenciada no alcance total da atividade humana, incluindo práticas funerárias.

Se a atividade humana transforma o fenômeno das práticas funerárias e na transformação inclui suas tecnologias, uma ilustração mais feliz pode ser encontrada nas tecnologias culinárias e no fenômeno de alimentar-se. Claude Lévi-Strauss, durante o ponto mais alto de sua popularidade como um teórico antropológico, fez uma forte distinção natureza/cultura como sendo a marca de sua teoria. A distinção geral preferida desta linha era a diferença entre o cru e o cozido (o primeiro ainda permanece sob a aura da "natureza"; o segundo é, claramente, "cultural"). 
Técnicas (mesmo que não imediatamente implicando tecnologias) de preparação de alimentos, em contraste ao simples ato de comer alimento material tal como encontrado, caracteriza uma atividade humana. O conhecimento de quais plantas são comestíveis e quais não são, excluindo a grande familiaridade indígena com as plantas terapêuticas ou tóxicas, é verdadeiramente surpreendente naquelas culturas próximas ao estado do nosso Jardim mitológico. (Este conhecimento é quase sempre perdido pelas formas posteriores de vida cultural que não mais possuem a práxis da caça e coleta ou da agricultura. Aqui está um exemplo preliminar de um estado contra progressivo nas culturas "avançadas".) Este conhecimento é complicado pelo ato de conhecer técnicas para desintoxicar muitas plantas tóxicas. As práticas posteriores usualmente empregam meios tecnológicos (normalmente cozinhar, o que utiliza o fogo, potes, etc.). Tais técnicas e tecnologias tornaram-se gradativamente mais complexas com o desenvolvimento civilizacional. De um simples alimentar-se com mãos e dedos, passando por colheres, até chegar a toda ordem das tecnologias da alimentação (de garfo/faca/colher multiplicados de muitas formas, aos pauzinhos japoneses), as variantes são muitas.

Formas de tecnologias culinárias também são interessantes. As tecnologias que empregam o wok e o vapor do Oriente são estilisticamente e de uma sabedoria técnica diferente dos fornos e pás, ou panelas e caçarolas, feitos na África, que novamente são diferentes dos processos com potes e panelas da Europa. Aqui está um exemplo inicial da multiestabilidade tecnológica.

Esses exemplos, relacionados a qualquer aspecto da ação humana, podem ser multiplicados. Virtualmente toda área da práxis implica uma tecnologia. Desde funerais até nascimento, de comer e trabalhar, o uso de artefatos incorporado numa práxis-padrão demarca o humano no mundo dele ou dela. Para reverter a equação usual, a forma de vida tecnológica é parte e parcela da cultura, tal como cultura, no sentido humano, inevitavelmente implica tecnologias.

Ao olhar para as tecnologias nesse sentido amplo inicial, nós podemos notar que, em contraste ao Jardim não tecnológico, a atividade humana desde tempos imemoriais ao longo da diversidade de culturas sempre foi tecnologicamente incorporada. Isso não é ainda levar em conta das tradições minimalistas comparadas com as maximalistas ou dos desenvolvimentos tradicionais comparados aos de alta tecnologia, que também estão distribuídos diferentemente ao longo dos tempos e das culturas. Isto é ter antecipado como as muitas formas da vida humana são completamente condicionadas materialmente. 
Esse desvio rumo ao Jardim como um contraste imaginativo ao mundo atual das interações humano-tecnologia foi tomado por propósitos heurísticos e sugestivos. O "retorno" para tal Jardim é igualmente nem desejável e nem possível. Dado o conteúdo e a magnitude da população humana da terra, se fôssemos perder nossa capacidade tecnológica amanhã, o resultado da subsequente crise aproximaria, talvez mais dolorosa e vagarosamente, precisamente o provável desfecho de uma guerra nuclear na devastação humana. Os sobreviventes seriam aqueles que de alguma forma encontram a si mesmo nos poucos lugares dos trópicos notados na nossa primeira excursão pelo Jardim. Nesse sentido, o fim do mundo não tecnológico não é terrivelmente diferente em resultado de um final tecnológico, mesmo que o primeiro seja meramente uma possibilidade imaginativa e o segundo algo mais forte. Nós deixamos o Jardim e herdamos a Terra. 


\section{2 \\ Tecnologia e o Mundo da Vida}

A noção de tecnologia que eu desenvolvi até este ponto é a mais ampla possível enquanto ainda mantém uma ênfase sobre sua materialidade. Na metáfora inicial da navegação, tudo o que se pode distinguir é terra e mar. Agora é tempo para indicar mais precisamente quais métodos de navegação serão utilizados para se concluir a travessia.

O termo "mundo da vida" (lifeworld) será reconhecido pelos iniciados em filosofia como sendo o mesmo usado por Edmund Husserl em A crise das ciências europeias e a fenomenologia transcendental (1936). Enquanto eu não devo emprestar este termo e seu significado sem profundas modificações, ele servirá para localizar a investigação dentre as tradições da fenomenologia e de sua correlata origem hermenêutica. Essas tradições, no entanto, não são simplesmente idênticas. Fenomenologia, num sentido inicial e grosso modo, pode ser caracterizada como sendo o estilo filosófico que enfatiza certa interpretação da experiência humana e esta, em particular, concerne à percepção e a uma atividade corporal. Hermenêutica, por outro lado, surgiu a partir das disciplinas da interpretação textual e, posteriormente, um tipo de análise linguística (Continental). Se Husserl permanece como a figura central na fenomenologia, seu jovem colega, Martin Heidegger, foi o desenvolvedor central da hermenêutica fenomenologicamente orientada, ainda que ele também possa ser considerado o fundador da filosofia da tecnologia contemporânea. As conexões entre estas linhas filosóficas não são imediatamente aparentes. A investigação aqui une estas linhas em 
uma única que se propõe de maneira descritiva analisar tecnologia e o mundo da vida. Começando com a fenomenologia das relações humano-tecnologia e então se movendo para a hermenêutica do enraizamento tecnológico-cultural, o primeiro programa é este, e mesmo que desenhado a partir das tradições mencionadas, não se limita às suas formas passadas.

Existe certo risco em abertamente começar com a fenomenologia das relações humano-tecnologia porque, em seu foco experimentalista, a fenomenologia tem sido amplamente mal compreendida como sendo a análise puramente "subjetiva". Mesmo que na recente filosofia norte-americana da ciência tenha aparecido alguns esclarecimentos sobre tais compreensões distorcidas, certo pré-juízo ainda permanece junto às tradições dominantes.

Se for verdade que a filosofia fenomenológica tornou-se a análise da experiência humana, seu entendimento da ideia de vivência não é o mesmo que o entendimento do senso comum nem o das interpretações equivocadas dos padrões da fenomenologia como sendo subjetiva. Eu proponho compreender este problema diretamente por meio da delimitação de vários aspectos da vivência e o seu entendimento fenomenológico.

Na psicologia - disciplina que se poderia pensar intuitivamente ser a mais adequada para questionar a "vivência" - seus termos estão obsoletos. Vivência tornou-se como sendo, redundantemente, experiência subjetiva, e a maneira de acessá-la é por meio da introspecção. O conceito behavior (comportamento) substitui o que vinha sendo experiência; behavior era tido como aquilo que era externo e observável. Recentemente a versão de mundo vivido, na qual uma de suas dimensões é a não externamente observável interioridade, tem voltado nas psicologias conceituais. Mas em outro sentido, a vivência nunca de fato deixou a prática da psicologia. Ela está implícita na própria situação experimental.

Na prática, o psicólogo elabora uma experiência na qual o "sujeito" participa de alguns testes, tarefas ou o que seja. O psicólogo que também é um sujeito em certo sentido observa o experimento, interpreta seus resultados, etc. Mas qual é o status da observação? Ela não é experiência no estrito sentido? Agora, admitidamente, psicologia não é uma disciplina autorreflexiva, e nem o são a maioria das ciências em um sentido temático. Assim, a observação em si de uma experiência é tida funcionalmente como certa, embora existam controles dentre a comunidade de psicologistas para o criticismo de um procedimento experimental e implicitamente para a observação-vivência. Mas é obvio que sem a observação-vivência não pode haver ciência da psicologia. Nem se 
pode permitir a esta observação-vivência ser "meramente subjetiva", para que a psicologia em si não se torne um tipo de relativismo (para cada uma de suas próprias observações).

Uma análise fenomenológica preliminar da situação-vivência pode ajudar a clarificar a noção implícita de vivência de tais funções junto à psicologia. Fenomenólogos defendem que todas as vivências são experiências de alguma coisa. Isto é, vivência é referencial, e aquilo que é referido ou experimentado é alguma coisa que pode preencher o vazio. No caso dos psicólogos observando um experimento, o vazio pode ser:

\section{Psicólogo $\rightarrow$ (sujeito submetido a uma tarefa)}

Se o psicólogo não observa o experimento de fato, então podem ser simplesmente os resultados que serão vivenciados:

$$
\text { Psicólogo } \rightarrow \text { (resultados) }
$$

Em ambos os casos, o psicólogo vivencia o referencial, seja numa observação direta ou numa observação secundária (e o fenomenólogo pode muito bem apontar que a primeira é uma tarefa perceptual informada, e a segunda é um exercício mais explicitamente hermenêutico-perceptual).

A vivência do psicólogo é necessariamente "subjetiva" em certo sentido, mas também é mais que subjetiva, pois possui seu próprio contexto de limitação ou "objetividade". Tais limitações incluem revisão por pares (intersubjetividade), delineamento experimental (restrições de contexto) e assim por diante. O treinado, observação de especialistas, é simplesmente um tipo particular de vivência, mas que certamente não é simplesmente "meramente subjetivo." E a mesma estrutura da vivência de 1 pertence para cada uma das ciências.

Se a psicologia, por suas próprias razões peculiares, decidir reduzir seu objeto de estudo às suas "externas" ou diretamente observáveis dimensões, a física tem sido mais sofisticada no que diz respeito à dificuldade em isolar o objeto. Por exemplo, o "comportamento" dos átomos e seus constituintes não são diretamente observáveis, mas são disponibilizados por meio da mediação tecnológica (instrumental) nas situações de observação. A câmara de bolhas, os aceleradores e os microscópios eletrônicos e computadorizados, todos trazem a mediada ou a presença indireta do microfenômeno, que é de interesse para o

1 Lacuna presente no texto original, o que também ocorre em outras partes. 
físico. Mas o físico, tal como o psicólogo, pode insistir que a experiência envolvida na observação deve ser de um tipo especial. Ela deve ser uma observação treinada e informada, e o observador deve passar por um aprendizado adequado, ainda que todas as experiências permaneçam experimentais, sem o que não poderia haver ciência. A filosofia, e em particular a fenomenologia, toma, no entanto, como seu primeiro fenômeno a estrutura da experiência em si mesma. Mas se a estrutura da experiência tornou-se o tema dominante da fenomenologia, isso ocorreu apenas porque o alcance completo e as múltiplas dimensões de tal estrutura precisam ser examinados. Por essa razão, Husserl inicialmente caracterizou seus passos iniciais como sendo a "ciência das vivências". Tal ciência não pode simplesmente reduzir seus campos a algum aspecto arbitrário do todo. Ambos os aspectos - externos e internos, subjetivo e objetivo - devem ser incluídos. Nesse sentido, a fenomenologia retém uma estratégia não redutivista no que diz respeito ao seu campo de investigação.

Num sentido mais profundo, no entanto, a fenomenologia, no que diz respeito à experiência, não se limita a um paralelismo com a psicologia. Antes disso, ela vai além ao produzir reivindicações ontológicas muito mais fortes. Isto é demonstrado no desenvolvimento subsequente da fenomenologia produzido por Martin Heidegger em Ser e Tempo (1927). O fato de tornar existencialista a ciência do mundo vivido de Husserl foi, de fato, o desenvolvimento do que eu denominarei de ontologia relativista da existência humana. Aqui eu devo apontar que um perfil relativista não é necessariamente um relativismo. Antes, um perfil relativista é um perfil das relações. No caso de Heidegger, trata-se de um perfil das relações humano-mundo, as quais determinam e definem as dimensões da existência humana (Dasein). Ser e Tempo tinha um perfil da espacialidade humana junto ao Mundo, da temporalidade humana junto ao Mundo e das várias estruturas e dimensões das relações humano-mundo.

De fato, eu sugiro como modelo metafórico para entender a fenomenologia precisamente o da ciência relativista. Uma maneira simples de afirmar este modelo é indicar que o primitivo do sistema (a menor ou mais simples unidade) é em si um conjunto de relações:

$$
\text { Eu---relação---Mundo }
$$

E ao passo que eu deva fazer tais relações mais precisas quando o programa a respeito das relações humano-tecnologia iniciarem, eis aqui uma comparação preliminar junto a um exemplo de relativismo bem famoso que pode ser 
utilizado. Trata-se de uma modificação sobre o exemplo de Einstein empregado para ilustrar as observações relativistas.

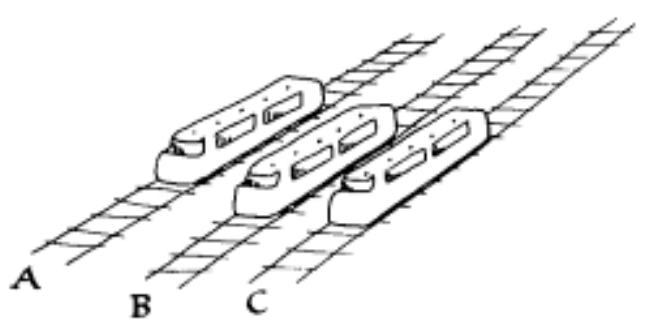

Se existirem três trens em três trilhos paralelos, o movimento observado vai ser relativo: (a) à posição do observador em relação; (b) ao que é observado. Relativo, neste caso, é que aquilo que se observa e a posição de onde se observa e a inter-relação entre ambos também deve ser levada em conta. Assim, se o observador estiver parado no trem $\mathrm{B}$ e notar que o trem $\mathrm{C}$ está se movendo para trás, algumas hipóteses são possíveis: ou o trem $\mathrm{B}$ está parado e o trem $\mathrm{C}$ está se movimentando para trás; ou o trem C está parado e o trem B está se movimentando para frente, fazendo parecer para alguém no trem $B$ que o trem $C$ está voltando para trás; ou que ambos os trens estão em movimento. Colocar observadores nos trens A e C e considerar todas as possibilidades de movimento dos trens pode demonstrar toda a complexidade desta situação, mas em cada caso existe uma "estabilidade" na relação observador-observado.

Também pode notar-se que em tal situação relativista, que toma em consideração igualmente observador-observado (como uma relação), pode também absorver conceitualmente qualquer situação absoluta ou não observacional. Por exemplo, quando ingenuamente perguntamos qual trem está "realmente" se movendo, nós podemos elaborar uma quarta posição de observação: uma torre de observação, D, a qual permite uma visão panorâmica de todo o espaço (Figura 2). Um observador aqui pode não estar sujeito à relatividade dos observadores dentro dos trens e pode dizer qual das hipóteses era "verdade". 


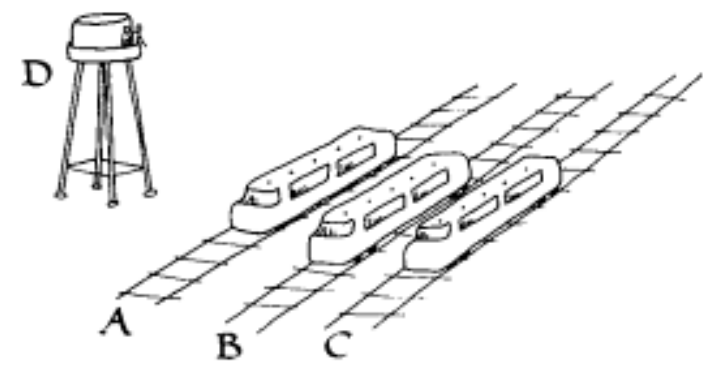

Esta posição privilegiada não escapa do poder absortivo do fato relativístico; no entanto, tomar tal posição como sendo privilegiada é simplesmente separar a relatividade entre o observador e o que é observado. Isso faz o espectro daquilo que é descrito mais compreensivo e mais complexo. A situação agora consiste em trens tal como descrito (em movimento ou não) em relação ao solo (que é tido como algo que não está se movendo), mas isso não elimina a relatividade da situação de forma alguma. A "arbitrariedade" regional de empregar superioridade à posição da torre pode em si ser transcendida para uma situação em que a terra em si é observada a partir de algum ponto mais distante, o que pode demonstrar que o que foi tomado como sendo imóvel, tal como o solo em si, é relativo ao movimento de toda a terra ao longo de sua órbita, e assim ad infinitum. Porém, a constante do observador-observado deve permanecer a mesma não importando qual seja a distância ou posição ocupada.

A perspectiva fenomenológica, tal como a relativista esboçada, sempre toma como primitivo a relatividade do humano no campo da experiência. Nesse sentido, ela é rigorosamente relativista. A relatividade das relações humano-mundo são reivindicadas por fenomenólogos como sendo um aspecto ontológico de todo o conhecimento, de toda a experiência. Negativamente, poderia ser reivindicado que não existe nenhuma forma de "escapar" desta situação relativista, e qualquer reivindicação contrária pode ser apontada como sendo igualmente ingênua ou equivocada. Nesse sentido, a fenomenologia é para todas as filosofias fundacionistas o que a relatividade é para a física newtoniana.

Esses são comentários gerais sobre o modelo fenomenológico de conhecimento e experiência. Para nos aproximarmos da investigação mais específica sobre as relações humano-tecnologia, uma segunda ciência análoga pode ser utilizada. A qualquer coisa mais que possa se juntar à análise das relações humano-tecnologia, pretendo manter o senso de materialidade que são próprios 
das tecnologias. Tal materialidade é correlata à nossa materialidade corpórea, a experiência que temos como sendo com nossos corpos em um ambiente. A ciência análoga aqui poderia ser a ecologia animal.

A ecologia é igualmente relativista, mas num sentido mais concreto e biológico. Ela é o estudo dos organismos em relação aos seus ambientes, no interior de alguns sistemas ecológicos específicos. Falando de maneira breve, um organismo é estudado em relação ao seu campo, seja simples ou complexo. Aqui, novamente, é algo análogo ao modelo da figura do solo. A figura (organismo) inter-relaciona-se com seu solo (meio-ambiente), e o estudo desta interação é a ecologia. Fenomenologia, particularmente no que diz respeito à sua atividade de tornar existencialista a existência corpórea, é um tipo de ecologia filosófica. Mas se trata de uma ecologia com uma diferença: O "organismo" que deve ser estudado não é e não pode ser estudado "a partir do exterior" ou de sobrevoo, porque, neste caso, nós somos ele. A ecologia humana que é fenomenologia é assim, duplamente, existencialista e relativista.

No exemplo einsteiniano, posições imaginárias podem ser assumidas arbitrariamente. Num sentido mais fundamental, no entanto, há sempre uma posição em que um ser finito e corpóreo precisa assumir e de fato ser. De maneira similar, ecologicamente, pode existir uma ampla variedade de estruturas organismo-ambiente, embora existam condições complexas relacionadas a cada uma, as quais devem ser ocupadas. E tal estrutura necessariamente possui seus correlatos corpóreos.

Ao utilizar as analogias destas duas ciências relativistas, pode-se notar que filosofia fenomenológica, mesmo que não eliminando a interioridade ou o aspecto "privado" da experiência humana, em nenhum sentido é limitada a eles. Ao contrário, seus limites são aqueles impostos pelo contexto relativista das relações (eu-mundo) e ulteriormente contrastados pelo reconhecimento explícito que, neste caso, um polo da relação é o que eu sou (junto à relação).

É também junto a esta conjectura que a apropriação possível da relatividade fenomenológica faz contato com a descrição das relações humano-tecnologia. Eu tenho insistido repetidamente que a materialidade das tecnologias se dão na concretude como numa espécie de "hardware" que num sentido mais amplo se conecta com a nossa existência corpórea igualmente concreta. Em sua história, a fenomenologia teve um crescente desenvolvimento existencial, e o termo "existencial" neste contexto se refere à experiência corpórea e ao sensível, uma forma de "materialidade fenomenológica". Tecnologias, nesse sentido, não são 
apenas apropriadas para a análise; elas recaem quase que naturalmente para o centro do debate filosófico.

Tecnologias, ao passo que elas são artefatos (num espectro que vai de simples entidades a todo um conjunto de sistemas complexos), são desenvolvidas, usadas e relacionadas aos humanos de formas distintas. Enquanto ainda existe certa necessidade em classificar as tecnologias como objetos (que é frequentemente o primeiro foco das descrições objetivistas), o que será levado em conta aqui são os conjuntos de relações humano-tecnologia, as relações que podem ser melhor exemplificadas numa forma sugerida de descrição relativista.

Existem algumas vantagens táticas para tal abordagem. Primeiramente, a relatividade fenomenológica evitará o que é considerado como sendo dois resultados extremistas em muito da literatura sobre o tema. Uma posição extrema é a que ultimamente reifica as tecnologias em Tecnologia. Uma versão de tal movimento, já mencionada, é a que absorve a tecnologia na técnica. Técnica, por sua vez, torna-se uma forma de prática e pensamento, que é tão geral que não é capaz de diferenciar entre as relações particulares humano-tecnologia e a sua inclinação para demandas excessivamente metafísicas.

No uso que eu faço pode haver técnicas com ou sem tecnologias. Uma "técnica” sexual não é em si uma tecnologia (embora, num sentido derivado e secundário, se tal técnica é modelada a partir de algum processo mecânico, então haverá uma conexão interpretativa entre as duas). Igualmente, técnicas podem estar intimamente ligadas às tecnologias, particularmente no que diz respeito aos padrões de uso.

A segunda vantagem de uma descrição relativista é a de superar o estado de coisas que argumenta sobre a presumida neutralidade das tecnologias. Interpretações neutralistas são invariavelmente não relativistas. Elas sustentam, com efeito, que as tecnologias são coisas em si, objetos isolados. Tal interpretação se localiza ao extremo oposto da posição de reificação. Tecnologias em si mesmas são concebidas como simples objetos, como tantos outros pedaços de lixo que estão à nossa volta. A arma no adesivo do vidro traseiro claramente, por si mesma, não faz nada; mas numa perspectiva relativista em que a unidade primitiva é a relação humano-tecnologia, torna-se imediatamente óbvio que a relação humano-arma (um humano com uma arma) frente a outro objeto ou outro humano é bem diferente de um humano com uma arma. A relação humano-arma transforma a situação de qualquer situação similar de um humano sem uma 
arma. Ao nível das megatecnologias, pode-se notar que os efeitos transformadores serão similarmente ampliados.

A terceira vantagem tática é a de preservar junto à análise algo do senso dinâmico ou ativo que se obtém nas relações humano-tecnologias. Não apenas as tecnologias são artefatos, mas elas são usadas (bem como são desenvolvidas, descartadas, etc.) em sua função normativa. E, embora o uso possa ser imediato, distante, ocasional ou postergado, a relação humano-tecnologia implica uma práxis humana ou ação. Como uma filosofia, a fenomenologia em si pertence à família das filosofias da práxis surgindo a partir de Hegel, Marx, pragmatismo e, num sentido derivado, do existencialismo. Humanos são o que são em termos da relação humano-mundo, mas essa relação na existência é acional. Igualmente os envolvimentos corpóreos-perceptivos e o desenvolvimento da noção de práxis serão essenciais para a investigação.

Há outra dimensão da fenomenologia que precisa ser mencionada nesta descrição preliminar. Não se trata apenas de um perfil relativista nos aspectos descritos, mas também estrutural. No exame de qualquer gama de relações que o fenomenólogo se comprometa, o que se busca é uma descrição, uma compreensão das estruturas de tais relações. Este será o objetivo mesmo: que as estruturas se mostrem simples e unidimensionais ou complexas e multidimensionais. Tal exame deve revelar igualmente os aspectos variáveis e invariáveis de tais estruturas. As questões aqui serão: quais estruturas relacionais se obtém no que diz respeito às relações humano-tecnologia? Quais são estes elementos diferentes de uma descrição fenomenológica que serão sintetizados? Qual é a dinâmica da atividade corpórea-perceptiva na práxis ativa a ser combinada com a elucidação de tais estruturas relacionais? Essa é a função da noção de mundo da vida. Sua origem, historicamente, vem de Husserl nos últimos dias de sua carreira, mas também pode ter sido a sua resposta ao apontamento inicial e mais histórico e existencial das relações humano-mundo feito por Heidegger. Em qualquer caso, no desenvolvimento husserliano da ideia de mundo da vida, repousam indícios que combinam os elementos necessários para unificar o tema desta investigação.

Superficialmente pode parecer que o objetivo de Husserl em seu contexto próprio é contrário ao foco necessário aqui. A crise nas ciências europeias e a filosofia contra a qual Husserl estava argumentando, em parte, era a mesma que depois teve que se opor ao Positivismo, uma ameaça à ideia do progresso científico racional. Em sua própria resposta, Husserl buscou desenvolver uma teoria do progresso racional isolando os meios em que ciências eidéticas - nas 
quais a matemática e a geometria eram os exemplos primordiais - poderiam surgir a partir de um contexto prévio mais concreto e material. Então, tais ciências eidéticas poderiam ser idealizadas ou tornadas autônomas das condições materiais e, assim, de maneira cuidadosa e qualificada, ser consideradas então como acumulações culturais. Sua análise repousava sobre o desenvolvimento dos graus crescentes do ideal ou abstração.

A respeito disso, há um sugestivo núcleo contendo sua derivação e conceito sobre o mundo da vida que pode ser redirecionado para a investigação acerca da tecnologia. Depois eu devo argumentar mais sobre derivação, mas inicialmente a ilustração que ele fornece no famoso apêndice à Crise, "A Origem da Geometria”, pode abrir o caminho para os aspectos chave da noção de mundo da vida:

É evidente que, na vida das necessidades práticas, certas particularizações de forma se destacaram e que uma práxis técnica sempre voltada para a produção de formas particulares preferidas e para a melhoria delas de acordo com certas direções de gradualidade. O primeiro a ser destacado a partir da coisa-forma são superfícies mais ou menos "lisas", mais ou menos perfeitas superfícies; contornos mais ou menos ásperos, ou bastante "planos"; em outras palavras, linhas mais ou menos puras, ângulos, pontos mais ou menos perfeitos; então, novamente, dentre as linhas, por exemplo, linhas retas são especialmente preferidas; e dentre as superfícies, as superfícies planas, para propósitos práticos, por exemplo, bordas limitadas por superfícies planas, linhas retas e pontos são os preferidos, enquanto superfícies totalmente curvadas são as indesejadas para muitos dos interesses práticos. Assim, a produção de superfícies planas e sua perfeição (polimento) sempre desempenha seu papel na práxis. ${ }^{2}$

Husserl está justamente interessado na origem do pensamento geométrico a partir das atividades práticas. Mundo da vida combina igualmente um perfil genético (histórico) e um estrutural. $\mathrm{E}$ a derivação claramente demonstra, apesar do racionalismo de Husserl, a proximidade com as filosofias da práxis (tais como as de Marx e Dewey) na medida em que algumas espécies de ações subjazem posteriormente em desenvolvimentos mais abstratos.

No exemplo empregado, o qual eu devo chamar de o "exemplo mobiliário", Husserl trai sua escolha usual de coisas familiares bem como a sua estrutura metafísica implícita. Ao nível da atividade prática, coisas são coisas materiais

2 HUSSERL, Edmund. The Crisis in European Sciences and Transcendental Phenomenology; trans, David Carr. Evanston: Northwestern University Press, 1970, p. 375. 
e basicamente vivenciadas em plena (multidimensionais e complexas), e aqui elas são colocadas em prática por um marceneiro. $\mathrm{O}$ emergente geômetra à espreita no marceneiro começa a nascer, selecionando e preferindo alguns aspectos de seu material (bordas, tal como Husserl sugere). Aqui devemos notar que Husserl é crítico e suficientemente ciente de que tal seleção é, de fato, uma escolha e implica que outras trajetórias possam ser tomadas. A escolha do geômetra, no entanto, origina-se na preferência por um conjunto de formas (pontos, linhas retas, superfícies). E ao se concentrar e desenvolver sobre elas, uma nova (e não marceneiro) prática pode ser desenvolvida. (O exemplo de Husserl sempre me pareceu "cozinhado". Fosse o marceneiro construir um navio, por exemplo, suas escolhas de forma seriam muito diferentes; elas incluiriam uma preferência por curvas, curvas compostas, cônicas, em vez de ângulos simples, superfícies e linhas no exemplo de Husserl. Mas esta escolha teria feito a conexão com a origem da geometria mais difícil, de fato, uma vez que, em contraste com a geometria plana, a geometria mais complexa necessária no exemplo para a construção de navios dificilmente poderia ser a geometria primitiva. Historicamente, é claro, a construção naval continuou sem uma ciência geométrica até recentemente na história.)

A práxis geométrica, uma vez derivada e tornando-se autônoma, carrega consigo um novo conjunto de formas de visão. Ela é uma aquisição cultural que pode ser repetida e, assim, uma vez sedimentada na experiência cultural, se torna intuitiva ou tomada como certa. (Aqui outro mal-entendido grotesco da fenomenologia pode ser mencionado. A acusação de que a fenomenologia recai no "mito daquilo que é dado", tal como Wilfred Sellars pode ter feito, é simplesmente falsa. Husserl frequentemente se referre ao que é intuitivamente dado, mas ele se valeu disso inicialmente; isto é, era para servir como um tópico para ser investigado. Contrariamente, intuições, tal como o exemplo do geômetra aponta, são constituídas. Apenas quando já constituídas e feitas familiares é que elas se tornam totalmente intuitivas ou "dadas".)

O problema que emergiu para Husserl foi aquele que agora é visto como sendo dois níveis de práxis: um material e prático (o contexto do marceneiro) e o outro ideal e teorético (o contexto do geômetra). Ambos pertencem, em certo sentido, ao mundo da vida, e ambos podem ser familiarizados com certo padrão praxiológico. Em parte, no entanto, esta tensão surge porque Husserl combinou dois tipos bem diferentes de práxis e fez com que um derivasse do outro. 
A modificação que devo fazer aqui sobre o exemplo e Husserl é no sentido de distinguir dois sentidos da percepção. O que é usualmente tomado como percepção sensorial (o que imediatamente e corporalmente focada na que se vê, se ouve, no momento atual), eu denominarei micropercepção. Mas também há o que pode ser chamado de percepção cultural, hermenêutica, o que denominarei macropercepção. Ambas pertencem igualmente ao mundo da vida. $\mathrm{E}$ ambas as dimensões da percepção estão intimamente conectadas e entrelaçadas. Não existe micropercepção (sensorial-corpórea) sem sua localização junto ao campo da macropercepção e não há macropercepção sem o seu foco microperceptivo.

A relação entre o a micro e a macropercepção não é uma derivação; ao contrário, ela é mais parecida com as figuras da Gestalt em que a micropercepção ocorre de acordo com um contexto hermenêutico-cultural; mas todos estes contextos realizam-se apenas no alcance das possibilidades microperceptivas. A implicação para a noção de mundo da vida será que esta investigação vai ser não fundacionista com algumas claras qualificações que precisam, assim, serem necessariamente colocadas sobre a ideia de acumulações.

Essa modificação sobre as distinções husserlianas tradicionais pode permitir uma descrição clarificante de como o mundo da vida se transforma. $\mathrm{Na}$ medida em que as macropercepções variam radicalmente, a relação para qualquer micropercepção também deve variar, ao menos no contexto do significado. Histórias culturais são histórias variantes, mas elas permanecem focadas na nossa existência corpórea.

Mais imediatamente, esta modificação implica uma análise em dupla face sobre o alcance das relações humano-tecnologia dentre os limites da micropercepção e experiência corpórea; o outro aspecto da análise deve permanecer sobre a hermenêutica cultural que situa nossa vida existencial. Na medida em que a percepção corpórea tem uma estrutura, vou alegar que sua estrutura multidimensional fornece certos contrastes sobre a perceptividade e que ela também possui uma série multiestável de ambiguidade, tal que essa estrutura é compatível com vasta série dos diferentes contextos cultural-hermenêuticos. Dessa forma, a análise deve ser completada tendo em conta o campo último em que tal micropercepção possa ocorrer.

Virtualmente, todo exemplo do intercâmbio entre o humano-tecnologia pode ilustrar esta inter-relação. Tome a seguinte interpretação sobre a estória da raposa e das uvas: a raposa, vendo que as uvas eram muito altas para serem alcançadas pela capacidade de salto de seu corpo, conclui que as uvas eram azedas; 
mas os humanos, inicialmente também incapazes de alcançar ou pular até as uvas, pegam uma vareta e derrubam as uvas, assim não acham ser necessário concluir que as uvas são azedas. Ambos, raposa e humano, no sentido microperceptivo mais estreito, percebem as uvas como sendo comestíveis e desejáveis, mas o contexto tecnológico primitivo tornado possível pela vareta muda o sentido perceptivo das uvas como atingíveis e, com ele, a macropercepção que o humano tem igualmente sobre o objeto da percepção e sobre sua habilidade de obter tal objeto. 


\section{3 \\ MUNDO DA VIDA: PRÁXIS E PERCEPÇÃo}

Do ponto de vista de um humano atual, o mundo da vida sem tecnologia pode ser no máximo uma projeção imaginativa. Ainda que qualquer análise de tal mundo ou mesmo da diferença entre os mundos tecnológicos e não tecnológicos deva começar de tal modo que as tecnologias possam tomar seu lugar próprio no mundo. As dificuldades de não prejudicar o caso em qualquer direção não são sem precedentes nas tradições filosóficas que adotei: a fenomenologia e a hermenêutica. Antes de me voltar aos meus próprios exemplos, olharei brevemente para três análises prototípicas no âmbito desta tradição: o martelo, de Heidegger; o Galileu, de Husserl; e a pena, de Merleau-Ponty.

\section{A. O Martelo de Heidegger}

Martin Heidegger certamente é conhecido como um dos filósofos mais importantes da tecnologia. Já em Ser e Tempo (1927), existem análises prototípicas da experiência tecnológica e suas implicações. Ser e Tempo de fato precede a Crise (1936), de Husserl, e como uma resposta e crítica ao seu antigo colega de trabalho, ele também ajuda a provocar uma virada em sua ênfase tardia acerca da noção de mundo da vida.

O que estava em jogo era a diferença entre as orientações epistemológicas e praxiológicas para a filosofia. Um modo de caracterizar o debate era comparar 
as formas como os humanos conhecem ou interagem com os objetos do conhecimento à sua interação com os objetos em uso ou equipamentos. Heidegger considerava que estes últimos estão mais próximos de nossa experiência comum e também que essas experiências são mais básicas, com formas especificamente tematizadas do conhecimento de objetos derivadas da primeira. "O tipo de operação que está mais próxima de nós, como temos demonstrado, não é uma estrita cognição perceptiva que manipula coisas e as coloca em uso; e isto tem o seu próprio tipo de 'conhecimento."' ${ }^{1}$ Foi para este tipo de conhecimento que o famoso exemplo do martelo foi concebido. A análise foi sobre um martelo de um exemplo de uma oficina tipicamente heideggeriana, muito provavelmente tomada a partir do contexto de um sapateiro. A análise era para ser uma profunda fenomenologia das ações em que ocorrem o ato de martelar em tal oficina. As variantes primárias do exemplo podem ser denominadas o uso normal, o sapateiro ou o marceneiro usando o martelo para colocar pregos em contraste com uma situação anormal em que o martelo acaba sendo quebrado ou está ausente. Dentre estas duas variáveis, Heidegger desenvolve suas operações fenomenológicas. Nesta análise, Heidegger desenvolve sua própria versão da fenomenologia, moldada para a ênfase pragmática. Tomando ferramentas ou equipamentos como coisas básicas encontradas no ambiente circundante, ele aplicou o que já vimos como sendo as características de forma da fenomenologia: primeiro, todos os objetos (neste caso objetos em uso também) são relativos a um contexto. Não existem objetos em si mesmos. Num contexto de objeto em uso, "tomado estritamente, um instrumento nunca 'é. O instrumento só pode ser o que é num todo instrumental que sempre pertence a seu ser." ${ }^{2}$ Este campo em que uma ferramenta é o que pode ser é um campo complexo permeado com "envolvimentos" ou relações transversais; segundo, estas relações transversais possuem o que pode ser chamado de uma "intencionalidade" instrumental, ou referência, definida pelo projeto de trabalho. Instrumentos são "algo para Na estrutura 'ser para, acha-se uma atribuição ou referência de algo para algo.” ${ }^{3}$

Mesmo o simples exemplo de um martelo contempla estas descrições: o marceneiro toma o martelo com o avental cheio de pregos, talvez um pouco de telhas, e atravessa os pregos nelas em um telhado. Aqui o envolvimento do

1 Martin Heidegger, Being and Time, trans. John Macquarrie and Edward Robinson. New York: Harper and Row, 1962, p. 95.

2 Ibid, p. 97.

3 Ibid., p. 97. 
martelo com os pregos, as telhas e o telhado junto a um projeto é suficientemente evidente. E a referência focal também é aparente.

Mas em tais contextos práticos, uma terceira característica complica a análise, porque ocorre a peculiaridade no que diz respeito ao usuário. A ferramenta ou o equipamento em uso se torna o meio, não o objeto, da experiência. "O que está imediatamente à mão se caracteriza por recolher-se em sua manualidade para, justamente assim, ficar à mão". ${ }^{4}$ Este afastamento da tecnologia do âmbito das experiências diretas é o que depois eu denominarei uma relação de incorporação [embodiment relation].

Mesmo se objetos de conhecimento estivessem "simplesmente ali" para inspeção, em contraste à indirecionabilidade dos objetos em uso, a questão de como fazer as situações de uso visíveis deveriam permanecer um problema. A tentativa de Heidegger para fazer isto se dá porum giro "negativo" (como eu denominei) junto à indirecionabilidade. O campo completo de envolvimentos e a referencialidade do contexto de uso pode ser mostrado através da quebra, do mau funcionamento ou da ausência de uma ferramenta.

$\mathrm{Na}$ ocupação, o ente que está mais imediatamente à mão pode ser encontrado como algo que não é passível de ser empregado ou como algo que não se acha em condições de cumprir seu emprego específico. A ferramenta se apresenta danificada, o material inadequado. Em todo o caso, um instrumento está aqui à mão. Mas o que a impossibilidade do emprego descobre não é a constatação visual de propriedades e sim a circunvisão do modo de lidar no uso. Nessa descoberta da impossibilidade de emprego, o instrumento surpreende. ${ }^{5}$

Eu não examinarei todas as sutilezas da análise de Heidegger aqui, mas vou destacar duas características de sua análise, as quais retomarei depois como peculiaridades seletivas. Primeiro, Heidegger é bastante apontado por seus críticos por sua escolha por exemplos comuns a uma oficina. Seus exemplos positivos de tecnologia frequentemente são itens simples, tais como um martelo, neste caso, ou, depois, o farol de um automóvel. Similarmente, no reino dos artigos avaliados positivamente, podem-se encontrar os sapatos de um camponês, moinhos de vento ou templos gregos, enquanto que usinas hidroelétricas no Rio Reno recebem caracterizações negativas. Mais interessante, no entanto, é a derivação igualmente da objetividade e do conhecimento objetivo de certos aspectos do uso de objetos por meio de giros indiretos ou negativos. Depois eu 
devo apontar para aquilo que eu penso ser o resultado dessa coloração implícita das relações humano-tecnologia.

Essa advertência não pretende de forma algum demonstrar que a análise de Heidegger é incorreta. Que num contexto de envolvimentos relacionados a alguma tecnologia pode ser demonstrado por avarias ou mau funcionamento parece realmente claro. De fato, na primeira grave escassez mundial de combustíveis fósseis, a crise da gasolina de 1973, o conjunto de envolvimentos dos automóveis em uma rede muito vasta e complexa de envolvimentos industriais tornou-se igualmente óbvio e assustador. Isso até estimulou algumas reflexões mais sérias sobre a necessidade por fontes de energia alternativa e motivou algumas práticas de conservação em certa medida. No entanto, vou contra-argumentar que tal giro não é a única forma de fazer um determinado contexto ficar aparente.

Retornando à análise, uma razão pela qual o fenômeno de objetos em uso e seus tipos particulares de "conhecimento" podem ser negligenciados, de acordo com Heidegger, é precisamente porque durante o emprego de tais tecnologias o usuário é "absorvido". "O próprio Dasein, no âmbito de seu empenho ocupacional com o instrumento manual, não possui uma possibilidade ontológica em que, de certo modo, a mundanidade se lhe evidencia junto com o ente intramundano da ocupação?”' É esta absorção e a consequente retirada do equipamento em uso, acredita Heidegger, que justifica a rota indireta que ele toma.

Se fôssemos deixar repousar por si mesmos os insights a respeito de nossa absorção em projetos de trabalho e a retirada simultânea da ferramenta vivenciada, as implicações mais amplas de tais relações acionais poderiam ser desperdiçadas. Em última instância, Heidegger argumenta, ainda nos tempos de Ser e Tempo, que o "conhecimento" prático implica questões concernentes à tecnologia para uma interpretação da natureza em si.

A obra no horizonte de sua ocupação não é manuseada somente no mundo doméstico da oficina mas também no mundo público. Com ele, descobre-se a natureza do mundo circundante que, então, se torna acessível a qualquer um. Nos caminhos, ruas, pontes e edifícios, a ocupação descobre a natureza em determinada direção. Uma plataforma coberta leva em conta as intempéries do tempo, as instalações de iluminação pública levam em conta a escuridão. [...] Num relógio, leva-se sempre em conta determinada constelação do sistema cósmico.

6 Ibid,. p. 102. 
[...] No uso do instrumento relógio, manuseado discreta e diretamente, a natureza do mundo circundante também está à mão. ${ }^{7}$

Em suma, implícita em tais contextos tecnológicos está a visão de mundo que Heidegger argumentara depois que acabou por recair no ponto de vista de que o mundo - como um todo - é entendido como um "bem de consumo" para o uso humano.

Isto é dizer também que tais usos "revelam" o mundo. Aqui, bem antes da definição de Kuhn sobre as revoluções científicas como visões de mundo, Heidegger defendeu que tecnologias implicam uma forma de visão de mundo:

Pertence à essência da função de descoberta de cada empenho ocupacional no mundo imediato das obras a possibilidade de descobrir, segundo cada modo de empenho, o ente intramundano evocado na obra. Isso significa: descobri-lo nas referências constitutivas da obra, em vários graus de explicitação e em diferentes envergaduras de aprofundamento de circunvisão. ${ }^{8}$

Assim, no exemplo do martelo encontra-se, potencialmente, a plena entrada a uma filosofia da tecnologia.

\section{B. O Galileu de Husserl}

Nove anos depois de Ser e Tempo, a Crise de Edmund Husserl foi publicado. Neste trabalho o conceito de mundo da vida, complementado com uma ênfase revisada sobre a práxis e a percepção, emergiu. Em "A Origem da Geometria" eu já enfatizei que este Husserl "tardio" voltou-se a um tipo de exemplo mobiliário derivando a ciência da geometria a partir de atividades mais mundanas, tais como mensurações.

Mesmo que não saibamos quase nada sobre o mundo histórico circundante dos primeiros geômetras, uma cosia é certa, como uma estrutura essencial invariável que era um mundo de "coisas" incluindo os próprios seres humanos como sujeitos deste mundo; que todas as coisas necessariamente deveriam possuir um aspecto corpóreo. [...] Além disso, é claro que na vida das necessidades práticas, certas

7 Ibid., p. 101 8 Ibid., p. 101 
particularizações de forma se destacaram e que uma práxis técnica sempre voltada para a produção de formas escolhidas particulares e para a melhoria deles de acordo com certas direções de gradualidade. ${ }^{9}$

Posicionar a origem da geometria a partir de práticas diárias parece ter sido um tipo de concessão à ênfase heideggeriana inicial à práxis, mas esta concessão permaneceu apenas parcial e resultou num conjunto diferente de problemas para a versão husserliana de mundo da vida. Primeiramente, o mundo da vida foi claramente concebido por Husserl para ser um extrato mais básico (fundacional) do Mundo e também mais amplo em seu escopo. Qualquer "mundo" secundário ou especializado, como aquele de qualquer ciência, deve de alguma forma referir-se a este mundo básico. Isto também se aplica a esta derivação de geometria:

A metodologia geométrica de operativamente determinar algumas, e finalmente, todas as formas ideais... volta-se para a metodologia da determinação por topografia e medição em geral, praticando primeiro primitivamente e, em seguida, como uma arte no pré-científico e intuitivamente dado mundo circundante. ${ }^{10}$

A versão de Husserl da práxis neste mundo cultural amplo claramente não foi do tipo accional à moda heideggeriana. Ela foi, antes, o material intuitivo, corpóreo e perceptivo, mundo dos objetos. "No mundo circundante intuitivamente dado... nós vivenciamos 'corpos' não na forma de um corpo geometricamente-ideal, mas precisamente aqueles corpos que de fato podemos vivenciar, com o conteúdo que é o conteúdo atual da experiência." ${ }^{11} \mathrm{O}$ que é pré-científico ainda está imerso em uma caracterização como corpos materiais percebidos. As ciências formais e abstratas, tais como a geometria, portanto, devem afastar-se dessa materialidade para tornar-se o que elas são. Husserl viu isso como um processo de aperfeiçoamento: "Fora da práxis de aperfeiçoamento, de pressionar livremente na direção de horizontes de aperfeiçoamento concebíveis 'uma e outra vez', formas-limite emergem na direção em que a séria particular de aperfeiçoamentos tende." ${ }^{12}$

Esta é a introdução, no início de uma bifurcação entre o mundo da vida pré-científico e o "mundo" científico. Esta bifurcação fará com que o processo

9 HUSSERL, 1970, p. 375.

10 Ibid., p. 27.

11 Ibid., p. 25.

12 Ibid., p. 26. 
de aquisição cultural torne-se difícil para Husserl. A questão vem à tona na crítica de Husserl a Galileu, o introdutor de uma geometria matematizada na ciência inicial.

O Galileu de Husserl pode ser caracterizado a partir de um legado e de sua permanência em duas dimensões de mundo. Por um lado, ele vive, como todos vivem, no mundo da percepção em suas significações pré-científicas, dentre "corpos" incluindo o seu próprio corpo. Por outro lado, Galileu herda uma práxis especial de pensamento geométrico culturalmente adquirida, que ele direciona para um novo uso em sua física. Todo o movimento está, doravante, para ser matematizado e pensado de forma abstrata, distinta das qualidades sensoriais que pertencem aos próprios corpos que estão em movimento e que ainda pertencem em certo sentido ao mundo da vida pré-científico.

O problema orbita em torno da percepção sensorial. Formas, já devidamente subsumidas na geometria antiga, são apenas uma parte do mundo sensorial. Além disso, há aquilo que Husserl chama de qualidades sensoriais plenas (cores, por exemplo). Estas não são facilmente compreendidas sob a práxis geométrica.

\begin{abstract}
A dificuldade aqui repousa no fato de que o material pleno, as qualidades de sentidos específicas que concretamente preenchem o espaço-temporal e formas-aspectos do mundo dos corpos não podem, em suas próprias gradações, serem diretamente tratadas tais como são as formas em si mesmas. ${ }^{13}$
\end{abstract}

Assim, alguns meios devem ser criados para explicar essas qualidades plenas ou então é preciso perceber que o método geométrico é apenas uma práxis especial e limitada relacionada a um aspecto do mundo. A invenção de Galileu, Husserl afirma, é o desenvolvimento de um meio indireto de matematizar o pleno. Galileu deve encontrar um meio de traduzir os fenômenos plenos em fenômenos espaciais, a fim de se tornarem disponíveis para a análise geométrica. E é isso que ele faz.

Conceitualmente, este movimento, bem conhecido tanto em Galileu quanto em Descartes, é uma das primeiras formas de negar aos objetos suas qualidades plenas numa doutrina de qualidades primárias e secundárias. Grosso modo, o objeto em si é puramente uma entidade geométrica, uma res extensa; suas qualidades plenas não são localizadas no objeto, mas no sujeito. Cores são 
"subjetivas". Mas agora, desde que nós vemos a coisa igualmente como sendo extensa e colorida, deve haver alguma maneira de subsumir a cor na análise geométrica. E é aqui que a geometrização indireta começa a tomar forma. Deve haver algum índice de regularidade que, mesmo que não diretamente espacial, possa ser relacionado a alguma mensuração "espacial" direta ou por meio de um processo de tradução.

Agora no que diz respeito à matematização "indireta" deste aspecto do mundo que em si mesmo não é uma forma-de-mundo matematizável: tal matematização é concebível apenas no sentido de que as qualidades sensíveis específicas ("pleno") que podem ser vivenciados nos corpos intuídos estão intimamente relacionados em um tipo peculiar e regulamentado com as formas que essencialmente pertencem a ele. ${ }^{14}$

Nesta perspectiva, não ainda intuitiva, Galileu dramaticamente pavimenta o caminho para a física moderna, que, pensando bem, hoje, raramente são dadas com o procedimento:

O que nós experimentamos na vida pré-científica como cores, calor e peso pertencentes às coisas em si mesmas e casualmente vivenciadas como radiação de um corpo de calor que torna corpos adjacentes quentes, e como indica, é claro, em termos da física, tons-vibrações, calor-vibrações, i.e., eventos puros no mundo das formas. ${ }^{15}$

Muito disso é dado como certo de forma que alunos da graduação podem até mesmo dizer que "enxergam" comprimentos de onda.

Isso quer dizer que uma vez posto em forma de uma visão de mundo, a perspectiva de Galileu torna-se um tipo de macropercepção que pode ser tomada como certa com as possíveis modificações. E é precisamente aqui que a ambiguidade em Husserl atinge o seu próprio ápice. Porque se os novos meios de compreender os fenômenos tornam-se aquisições culturais genuínas, como a investigação sobre as origens por meio de uma práxis torna-se transparente, eles negligenciam o contraste com o mundo da vida fundamental.

Mas agora nós devemos notar algo da maior importância que ocorreu mesmo tão cedo quanto em Galileu: a substituição sub-reptícia

14 Ibid., p. 35.

15 Ibid., p. 36; itálicos meus. 
do mundo matematicamente subestruturado de idealidades para o único mundo real, o que é realmente dado através da percepção, que é sempre vivenciado e experimentável em nosso mundo da vida cotidiano. Esta substituição foi prontamente passada a frente para seus sucessores, os físicos de todos os séculos seguintes. ${ }^{16}$

Parece que Husserl está dizendo que em sua base o mundo da vida é e deve ser o mundo sensorial, baseado nas relações entre as ações humanas e o mundo concreto e material das coisas e seres corpóreos. E estes são intuitivamente e perceptivamente disponíveis para todos. Em seguida, um segundo tipo de "intuicionabilidade" também ocorre como na exemplificada revolução de Galileu, aquele em que certas combinações de perspectivas praxiológicas alcançadas podem tornar possível outra realização intuicionável, uma aquisição cultural como a ciência.

Tal aquisição, no entanto, também é ambígua, porque o que é adquirido pelos próprios meios da matematização, Husserl argumenta, perde um sentido essencial de concretude por negligenciar o mundo da vida fundamental.

Galileu, o descobridor... da física, ou da natureza física, é ao mesmo tempo uma descoberta e um gênio da dissimulação. Ele descobre a natureza matemática, a ideia metódica, ele abre caminho para o número infinito de descobertas e descobridores da física. [Mas] imediatamente e em seguida a Galileu, começa a substituição sub-reptícia da natureza idealizada pela natureza intuída pré-cientificamente. ${ }^{17}$

A aquisição de um novo paradigma esconde o fundamento da dimensão ordinária do mundo da vida.

O Galileu de Husserl, assim, é apanhado entre um pré-científico, mas perceptível mundo da vida e um científico, mas imperceptível mundo de idealidades.

Eu já sugeri que esta anomalia é, a meu ver, causada pela própria reconstrução da origem da ciência de Husserl. Ao fazer do mundo material-sensorial tanto pré-científico e fundacional por um lado, e esvaziando o mundo científico da percepção e da práxis como um "derivado", embora especial, "mundo" por outro lado, Husserl perde a inter-relação entre o que eu estou denominando de micro e macropercepção. 
Tal Galileu não é exclusivo de Husserl, ele é o Galileu da maioria das interpretações que privilegiam uma versão da teoria sobre a práxis. Ele é um Galileu imerso num raciocínio hipotético-dedutivo da visão dominante. É claro que ele também é o Galileu experimental, embora Husserl ignore os elementos praxiológicos desta prática. Este ponto de vista da ciência concentra-se sobre o que e como a ciência "pensa" em vez de sobre o que a ciência "faz".

Ciência e seu modo de ver é agora parte do nosso mundo macroperceptivo. É uma aquisição cultural que situa a estrita percepção corporal que nós retemos, mas que sobrepõe ou não se sobrepõe com o que deve ser, para nós, um mundo pré-científico perdido. O que está igualmente ausente a partir desta análise é a práxis atual da ciência moderna que, desde o seu começo, assenta sua concretização em tecnologias, em instrumentalização. Através dos instrumentos, a ciência em sua forma moderna nunca perde suas percepções. Considerando que Heidegger implicitamente começa a filosofia da tecnologia em relação a estas análises, Husserl ainda não abre a porta para tal filosofia. Nós temos que voltar novamente para Galileu.

\section{A Pena de Merleau-Ponty}

A terceira análise prototípica nesta tradição vem da obra de Maurice Merleau-Ponty. Seu livro Fenomenologia da Percepção (1945) tem a vantagem de ter igualmente Husserl e Heidegger como predecessores. Há um sentido em que Merleau-Ponty se tornou o esteticista perceptual da fenomenologia. Aqui se encontra uma riqueza descritiva muito mais sutil do que qualquer oficina heideggeriana ou mobiliário polido husserliano. Observe o seguinte:

Uma roda de madeira posta no chão não é, para a visão, aquilo que é um corpo em que forças contrárias se equilibram. [...] A visão já é habitada por um sentido que lhe dá uma função no espetáculo do mundo, assim como em nossa existência. [...] O problema é compreender estas relações singulares que se tecem entre as partes da paisagem ou entre a paisagem e mim enquanto sujeito incarnado. [...]O sentir é esta comunicação vital com o mundo que o torna presente para nós como lugar familiar de nossa vida. E a ele que o objeto percebido e o sujeito que percebem devem sua espessura. ${ }^{18}$

18 MERLEAU-PONTY, Maurice. Phenomenology of Perception, trans Colin Smith. New York: The Humanities Press, 1962 , p.52-53. 
Surge a pergunta: esta é uma vaidade estética ou ela exibe a base da consciência pós-moderna de uma percepção suficientemente sutil igualmente para a ciência e para as sensibilidades artísticas? Pois o que está finalmente superado aqui são as bases da ciência cartesiana e as sensações mais estritas da psicologia empirista.

O que Merleau-Ponty acrescenta a este processo de análise prototípica é a correlação estritamente fenomenológica entre o corpo "vivido" e o mundo percebido. A percepção do mundo da vida é a percepção que, microperceptivamente, sempre implica o corpo em ação:

O que importa para a orientação do espetáculo não é meu corpo tal como de fato ele é, enquanto coisa no espaço objetivo, mas meu corpo enquanto sistema de ações possíveis, um corpo virtual cujo "lugar" fenomenal é definido por sua tarefa e por sua situação. Meu corpo está ali onde ele tem algo a fazer. ${ }^{19}$

A existência corporal é acional, é orientada. E está correlacionada com um mundo circundante aberto à ação:

Não é preciso perguntar-se por que o ser é orientado, por que a existencial é espacial [ ...] a coexistência do corpo com o mundo polariza a experiência e faz surgir uma direção. A questão só poderia ser posta se esses fatos fossem acidentes que adviriam a um sujeito e a um objeto indiferentes ao espaço. A experiência nos mostra, ao contrário, que eles estão pressupostos em nosso encontro primordial com o ser, e que ser é sinônimo de ser situado. ${ }^{20}$

A micropercepção de Merleau-Ponty é sempre uma percepção cinestésica:

Meu corpo tem poder sobre o mundo quando minha percepção me oferece um espetáculo tão variado e tão claramente articulado quanto possível, e quando minhas intenções motoras, desdobrando-se, recebem do mundo as respostas que esperam. ${ }^{21}$

E é fora desta sensibilidade para uma correlação corpo-mundo que Merleau-Ponty antecipa um papel diferente para as tecnologias no domínio da percepção 
e da práxis. O corpo vivido ou virtual sendo uma espacialidade corporal vivenciada pode ser "expandida" por meio de artefatos:

Uma mulher mantém sem cálculo um intervalo seguro entre a pena de seu chapéu e os objetos que poderiam estraga-la, ela sente onde está a pena assim como nós senti os onde está nossa mão. Se eu tenho o hábito de dirigir um carro, eu o coloco em uma rua e vejo que "posso parar" sem comparar a largura da rua com a dos para-choques, assim como transponho uma porta sem comparar a largura da porta com a de meu corpo. ${ }^{22}$

Aqui, novamente, naquilo que eu denominarei relação de incorporação, Merleau-Ponty aponta que a percepção pode ser materialmente expandida através do "corpo" de um artefato. A extensão da percepção não é limitada pelo contorno do meu corpo ou pela superfície da minha pele. A descrição torna-se mais precisa no exemplo da "bengala do cego":

A bengala do cego deixou de ser para ele um objeto, ela não mais é percebida por si mesma, sua extremidade transformou-se em zona sensível, ela aumenta a amplitude e o raio de ação do tocar, tornou-se o análogo de um olhar. Na exploração dos objetos, o comprimento da bengala não intervém expressamente e como meio-termo: o cego o conhece pela posição dos objetos, antes que a posição dos objetos por ele. A posição dos objetos está imediatamente dada pela amplitude do gesto que a alcança e no qual está compreendido, além da potência de extensão do braço, o raio de ação da bengala..$^{23}$

Aqui se encontra a base para a percepção à distância, mediada por um artefato, uma tecnologia; e aqui jaz latente a fenomenologia da instrumentalização. Pode-se notar que esta análise complementa Heidegger. No exemplo do martelo, a ferramenta se "distancia"; na pena ou na bengala de Merleau-Ponty, entretanto, o artefato é uma parte do mundo alcançado por meio deste afastamento.

Um segundo aspecto que se encaixa no refinado esquema perceptivo de Merleau-Ponty é a inter-relação entre a percepção sensorial e o seu papel para a cultura. Em seu trabalho tardio O Visível e o Invisível (1961), ele explicitamente fala sobre a cultura "vivenciada": 
É um fato notável que o desinstruído não tem consciência de perspectiva e que demorou muito tempo e muita reflexão para que os homens se tornassem conscientes da deformação perspectiva dos objetos... Eu digo que a perspectiva renascentista é um fato cultural, que a própria percepção é polimórfica, e se ela se tornou euclidiana, isto é porque ele se permite ser orientado pelo sistema... O que eu afirmo é que: existe um informante da percepção pela cultura que nos permite dizer que a cultura é percebida. ${ }^{24}$

Relativo a esta observação de duas diferentes interpretações de ciência por Heidegger e Husserl, pode-se notar que a ciência para Merleau-Ponty poderia ser tal como uma cultura percebida. Aqui está um tipo de macropercepção que informa ou orienta a percepção corpórea em si mesma.

Estas três fenomenologias apontam de maneira distinta em direção à fenomenologia das relações humano-tecnologia. Não se buscou enquadrar estas análises em seu cenário histórico em uma filosofia da tecnologia, mas cada uma aponta para elementos que se tornam cruciais. E enquanto todas as fenomenologias são voltadas à "percepção", a versão da fenomenologia que eu devo esboçar aqui deriva de, mas também se difere de, daquelas de meus reconhecidos tutores. O que resta para o primeiro programa, a fenomenologia das relações humano-tecnologia, é reinserir o papel das tecnologias em todas as dimensões do mundo da vida.

24 MERLEAU-PONTY, Maurice. The Visible and the Invisible, trad. Alphonso Lingis. Evanston: Northewestern University Press, 1968, p. 212. 


\section{4}

\section{Adão e Galileu}

Num exercício imaginativo, retorne para o novo Éden e para o nosso pré-tecnológico novo Adão. O que nosso Adão nu poderia ver e contemplar a olho nu dos céus noturnos? De nossa situação atual nós sabemos que esta questão é duplamente suspeita. Não apenas pedimos isto a partir de nossa perspectiva de mundo tecnologicamente constituída, mas também devemos suspeitar que a própria imaginação de uma percepção “inocente” é, no mínimo, uma abstração.

O céu noturno é um paradigma virtual e uma ambiguidade perceptiva. Se fôssemos imaginar a visão nua de Adão, poderíamos ser tentados a caracterizar tal percepção como uma vastidão sombria, um campo perceptivo escuro com ponto de luz com variação de grau e intensidade e padrões aleatórios. Se o nosso Jardim do Éden é no Hemisfério Norte, haveria certa esbranquiçada, mas amorfa, área que atravessa o meio. Nós poderíamos ir adiante e caracterizar esta visão como uma base microperceptiva à qual poderiam ser atreladas interpretações macroperceptivas. Nosso Adão pré-tecnológico poderia ver em nível de visão microperceptiva.

Mas tão logo nós comecemos nossas variações a partir de nosso tempo cientificamente saturado, mesmo ao nível de uma consciência científica minimamente mediada pelos documentários televisivos, deveríamos suspeitar que tal Adão não existe. Ao contrário, em cada caso de pré-científica, se não pré-tecnológica, cultura, nós encontramos alguma visão sobre os céus mais ricamente descrita. Com efeito, o despojamento de tal micropercepção presumida provavelmente não seria reconhecida por nosso Adão afinal. Onde nós fomos 
de certa forma criticamente precisos, ele poderia dizer que tal linguagem claramente pertence de um modo único à nossa própria tribo, porque certamente ninguém olha para os céus de tal maneira reducionista!

O que nós tomamos como uma visão nua já contém a mesma relação secreta à macropercepção. As histórias da percepção nos ensinam que cada versão da micropercepção já está situada junto a e nunca dissociada do humano e da macropercepção cultural que já a contém. Não existe um simples enxergar; existe apenas um enxergar situado que é igualmente um enxergar como e um enxergar a partir Ainda aqui existem pistas iniciais para o exame fenomenológico.

Qualquer Adão empírico veria os céus como , no âmbito de alguma macropercepção concreta. As cosmologias descritivas antigas tais como aquelas do Oriente Médio tomam nosso céu visível como sendo um domo, escuro à noite, azul durante o dia, mas obviamente "sólido". Não há nenhuma ruptura em seu ser colorido ou em estar a esta ou aquela distância da terra. As luzes deste domo celeste podem ser buracos no domo por meio dos quais os fogos extracelestes aparecem, ou podemos achar que o sol, as demais estrelas ee a lua são viajantes ao longo do domo. Contrariamente, quando estudamos as cosmologias do Oriente Próximo, podemos descobrir que o céu é o aberto. Ele vai indefinidamente além da visão. Ambas essas versões descritivas são microperceptivamente possíveis.

De modo similar, se tomarmos o que inicialmente descrevemos como sendo padrões aleatórios (ou variantes macroperceptivas) de nosso Adão empírico ancestral, nós deveríamos descobrir que existem agrupamentos que também são vistos como sendo . Existem figuras do zodíaco dos gregos e romanos, as cerâmicas de nossos ancestrais norte-americanos, ou a baleia, a foca e o peixe dos povos do Norte longínquo. Cada tribo agrupa as estrelas em padrões, não aleatoriamente, não consistentemente um com outro, ainda assim sempre em grupos. Os agrupamentos, frequentemente, refletem padrões de vida e ações de um grupo de pessoas. Em uma sociedade agrícola, os padrões estrelares são correlatos aos vários ciclos das estações e da reprodução. Se a atividade for a navegação, as estrelas devem ser correlatas às rotas e aos destinos. Questões acerca das distâncias relativas das estrelas para a terra, por exemplo, não estarão apenas ausentes, mas não farão nenhum sentido no âmbito de tais paradigmas culturais.

Ao nível microperceptivo, a ausência de tais questionamentos faz seu próprio sentido. Objetos localizados a grandes distâncias são escorçados. Nós não 
percebemos (microperceptivamente) distâncias relativas entre as estralas, e esta é talvez uma razão pela qual as cosmologias antigas posicionavam as estrelas muito próximas à Terra do que as cosmologias mais recentes o fazem. Os surpreendentes resultados obtidos pelos gregos, que antecipam medições modernas, surgem igualmente de suas crenças matemáticas e de seu uso primitivo de instrumentos de medição. Suas percepções já iam se tornando em parte tecnologicamente mediadas, mas o uso de instrumentalização permanecia altamente restrito. Não havia, de modo algum, tecnologias óticas.

Os antigos observavam dinamicamente, sutilmente. Eles não apenas conheciam os padrões que eram "constelações", mas também mapearam os movimentos das estrelas e de outros corpos celestes de modo muito perspicaz. Agora nós sabemos que eles empregaram amplos e monumentais "compassos siderais", tal como Stonehenge no intuito de elaborar tais mapeamentos. Estes círculos de pedras estavam alinhados para localizar precisamente as posições, indicando os tempos exatos dos solstícios ou do nascente e poente de importantes estrelas e planetas. As tecnologias relativas aos calendários, túneis para observação da localização solar e outros instrumentos eram empregados para o detalhamento de movimentos cruciais aos padrões variáveis da vida diária, tal como os ciclos das estações e os assuntos astrológicos. Não havia percepções puras, embora todas as suas percepções contassem com as observações a olho nu, feitas para se enquadrar nas formas de vida que se estendem para os céus a partir da terra.

O que, agora, é percebido ao passo que nós nos voltamos para nossa própria variação. A criança precoce de hoje pode dizer que os céus são constituídos por galáxias de diversos formatos, espirais ou círculos concêntricos; que existem buracos negros ocultos e estrelas radioativas lá fora; que as estrelas não são todas de um mesmo tamanho, mas que incluem anãs brancas, gigantes vermelhas, ao infinito. Tais descrições, no entanto, não se entrosam facilmente com as visões antigas do céu noturno, mas contrastam com elas. Existe uma distância entre o que é visto olhando para cima numa noite clara distante das áreas urbanas poluídas com luzes artificiais e o que é apresentado para nós em fantásticas fotografias e representações das nebulosas e galáxias. E aqui nós podemos descobrir uma "distância" entre a velha versão do mundo da vida da percepção imediata e do mundo científico que nos distancia do primeiro.

Se fôssemos chegar a esta conclusão, no entanto, nós deveríamos deixar de lado precisamente o fator que contribui para a distância e simultaneamente para a proximidade da instrumentação tecnológica. Isto é assim porque existe 
uma diferença essencial entre nossa visão tecnologicamente incorporada e aquela de nossos antepassados. Nossas percepções não são nuas, mas mediadas. Nós enxergamos através de meios, primeiramente óticos, radioativos, espectrográficos e outras visões tecnologicamente incorporadas (ou ouvimos, ou tocamos). Enquanto existe uma grande distância visível entre a visão a olho nu do céu noturno e a representação dos céus na astronomia contemporânea, tal distância em si é mensurada por meio de nossas tecnologias sensoriais. Isso é o que nos distancia de nosso Adão mítico.

Igualmente a distância e a proximidade do tecnologicamente mediado e da visão nua são importantes. Não melhor do que nossos ancestrais, nós podemos microperceber as distâncias entre as estrelas. Nossa visão do céu noturno, sem o auxílio da ótica, não pode diretamente nos dizer que Rigel está mais próxima ou mais distante da terra do que Polaris; apenas que aquela é mais distante que a outra. Suas distâncias relativas não podem ser percebidas mesmo através de poderosos telescópios. Nós descobrimos as pistas para as vastas distâncias em parte porque o tamanho aparente dos discos estrelares permanecem os mesmos nos telescópios primitivos. No entanto, a lua e os planetas viajantes sofreram breves modificações. Ainda que, macroperceptivamente, nossa imagem seja o que é por meio da instrumentação que nos distancia de todos os Adãos, seus arranjos não são "errados" ou os nossos "certos"; eles são simplesmente incomensuráveis. Ambos são limitados ao relativismo que se liga ao visualizador e à visão, embora numa visão instrumentalmente mediada existam novos fatores.

Não apenas nossas percepções mudaram incomensuravelmente daquelas por meio de nossa instrumentalização incorporada em qualquer grau, mas também a nossa práxis. Apenas vestígios permanecem da ligação do mundo agrícola antigo em nossa visão. Nós suspeitamos que os ciclos das manchas solares podem estar relacionados, em certo sentido, a padrões climáticos de longos períodos. E estes, em contrapartida, aos ciclos de chuva e à estiagem, mas nossas inclinações instrumentais adentram em nossas práxis de maneira descontínua com os mundos dos antigos. Nós procuramos pelas próprias fronteiras, se é que exista alguma, do universo. A busca em si é possível apenas através do desenvolvimento de instrumentos cada vez mais poderosos. Esta inclinação não apenas é possível pela visão tecnologicamente incorporada, mas advém no âmbito do contexto da incorporação instrumental. Nossa episteme é diferente da de Adão, mas existem resquícios de interstícios de intersecção. 
Os interstícios repousam entre os caminhos flexíveis e ambíguos em que as micro e macropercepções estão conectadas. No entanto, por mais complexos e multifacetados que eles possam ser, existem aspectos estruturais discerníveis para a fenomenologia da percepção. Os que serão isolados aqui dizem respeito às diferenças entre as percepções tecnologicamente mediadas e nuas. Iniciarei permanecendo junto ao domínio daquilo que é familiar. Isto inclui o uso habitual de exemplos visuais, os quais ecoam nas várias metáforas que nós temos usado para descrever a ciência como uma "visão de mundo".

A diferença entre o novo Adão e nós mesmos é a diferença entre a micropercepção mediada e não mediada. Não precisamos voltar ao Jardim do Éden; a despeito de nosso próprio mundo tecnologicamente entrelaçado, continuamos tendo percepções não mediadas a nível micro: eu passeio ao ar livre no verão, em direção à praia. Lá, eu me dispo com exceção de um modesto traje de banho; primeiramente, eu sento na areia e me percebo. A sensação tátil da brisa, o calor da areia, o som das ondulações vindo das ondas, a visão dos arbustos nos limites da praia, as árvores plenamente cobertas de folhas ao longo da costa, tudo isto se apresenta para os meus sentidos de maneira não mediada. E chamarei isto simplesmente de (micro) percepção direta da situação. Eu tomo isto como certo. É familiar. E isto usualmente não é examinado. É uma forma fundamental na qual eu vivencio meu ambiente imediato ou mundo circundante. Formalmente denominarei tais percepções diretas ou não mediadas de relações eu-mundo.

Tais relações já incluem uma complexidade multidimensional. O que eu vivencio, qualquer coisa no mundo próximo a mim, é igualmente visto como e visto a partir de. Ondas, árvores, arbustos, areia, todos são "coisas" familiares da experiência, seres ordinários diante dos quais meus sentidos flexíveis possam ser direcionados. Eu não vivencio algo como uma construção destas coisas imediatas; elas já estão lá, sejam o que forem. Mas eu as vivencio no âmbito de um panorama, um campo disposto. As árvores estão do outro lado da enseada, com a árvore de faia à esquerda do bordo sicômoro. A gaivota voa acima do cisne que está nadando diretamente diante de mim. O panorama se estende até as bordas do que eu vejo ao meu redor.

Eu vivencio as diferenças entre o que se destaca no panorama em relação direta com a minha atenção e direção do olhar. Eu sou atraído, por curiosidade, ao caranguejo-ferradura que agora se aproxima lentamente ao limite da praia, acompanhado por seu insistente parceiro. Quando eu estou assim, direcionando 
meu olhar, aqueles itens à distância se tornam menos distintos e mais como campo de fundo ao drama imediato próximo aos meus pés.

Eu posso não estar explicitamente consciente da intencionalidade desta minha mirada ou das relações de forma entre o foco em primeiro plano e o campo de fundo, mas isso pode ser facilmente recuperado numa reflexão. Ademais, eu posso recuperar minha visão dinâmica como sendo simultaneamente uma visão a partir de. Aquele panorama imediato reflexivamente me localiza. O que está diante de mim reflexivamente de volta para um ser-aqui que é concreto, a espacialidade corporal que eu sou; mas este espaço corporal não é distinto. É, também, flexível e multidimensional.

Eu vivencio minha presença como sendo corpórea, um tipo de ambiguidade com a qual eu sinto da mesma forma o que está diante de mim e o que está ao fundo. Meu passo em direção à agora aquecida areia pelo sol repentinamente muda meu foco de consciência para a interface entre os pés e a areia, e eu me encaminho rapidamente para a água para mudar o quente em frio. Mas agora aliviado, eu volto a concentrar-me totalmente nos caranguejos acasalando. Estou imerso no mundo circundante, mas esta imersão é tão flexível e dinâmica quanto o panorama sobre mim. Este é o quiasma, o entrelaçamento da carne sobre o qual Merleau-Ponty falou em suas últimas interpretações a respeito da percepção.

Tudo isto é o interstício que eu compartilho com nosso novo Adão imaginado. $\mathrm{O}$ que ele não compartilha comigo, no entanto, é o mediado, a experiência perceptiva incorporada que eu tenho quando eu deixo o Éden. Pouco de minha vida é vivido nuamente; e quando o é assim vivido, nunca o é muito distante das vestes materiais que são nossa incorporação tecnológica. De fato, meu mundo distante se apresenta para mim durante meus anos médios com certa ambiguidade visual que eu não conhecia em minha juventude. Até mesmo para a praia agora eu levo meus óculos de sol, com meu traje de banho, o que preserva o decoro da modesta civilização tecnologicamente re-vestida em Poquott ${ }^{1}$.

Nem nosso Adão vivenciou a diferença entre seu mundo nuamente percebido ou o nosso. E aqui repousa a pista do que no novo Éden poderia ser a perda da inocência, mas, uma vez sobre a terra, torna-se mais que o conhecimento sobre o bem e o mal. E o conhecimento nasce a partir das diferenças, das variações que guardam os segredos para um mundo igualmente mais e menos inocente do que o de Adão. Mas tal como a própria familiaridade com a nossa

1 Nota do Tradutor: Poquott é uma vila litorânea localizada na cidade de Brookhaven, na costa norte de Long Island, parte da área metropolitana da cidade de Nova Iorque, NY, Estados Unidos. 
dimensão Adâmica pode ser deixada sem exame e sem ser discernida, assim também pode, da mesma forma, a qualidade de nossa relação mediada para com o mundo e a sua diferença da nossa relação nua com o mundo. Analisar ambas as mediações e suas diferenças é adentrar na fenomenologia.

O primeiro conjunto de variações é ótico e pode ser localizado sobre o que pode ser chamado de um continuum ótico. Imagine nosso Adão escalando um promontório do seu reino (jardim) e descobrindo o panorama da selva. Seus correspondentes contemporâneos podem fazer isto de um modo diferente, por exemplo, ao tomar o elevador para os andares mais altos de um arranha-céu e visualizar o skyline urbano através de uma janela de vidro recém-limpa.

Aqui nós temos o que pode parecer, numa primeira análise, uma diferença mínima entre uma visão direta ou nua do mundo e uma visão tecnológica (neste caso ótica) e mediada. Formalmente, nós podemos notar que a janela ocupa uma posição entre o observador e aquilo que é observado. A relação eu-mundo é transformada em eu-janela-mundo. Isto é mais que mudança formal; o modo como o mundo é vivenciado é transformado ontologicamente.

Isto, no entanto, pode não ser imediatamente aparente. De fato, a visão acrítica pode muito bem ser tentada a dizer que o panorama é exatamente o mesmo através da visão mediada pelo vidro incorporado e da visão a olho nu. À primeira vista, o que parece ser impressionante é a própria transparência do meio. $\mathrm{O}$ vidro permite que eu olhe, através dele, o mundo. $\mathrm{O}$ vidro, retomando a terminologia heideggeriana, "se distancia" do objetivo projetado da visão. Pode até ser dito, do modo como eu vejo, que o mesmo ocorre com os óculos. E, e se formalizarmos a relação eu-janela-mundo mais especificamente, podemos bem diagramá-la como sendo

$$
\text { (eu-janela)-mundo }
$$

Aqui os parênteses significam que a janela se distancia de tal modo que é, no máximo, o meio e, claramente, não o objeto da minha visão.

Existe, na maioria das situações deste tipo, certa quantidade de brilho refletido, possivelmente alguma translucidez residual quase imperceptível nas melhores placas de vidro, o suficiente para uma delicada variação entre os dois pontos de vista, revelando que o distanciamento da janela nunca é total. Existe sempre um ligeiro, mas perceptível achatamento da profundidade do panorama, mas, imaginativamente, há várias destas extremamente sutis diferenças entre 
uma tentativa (mas nunca de fato obtida) transparência pura e algum grande grau de translucidez como um continuum em direção ao opaco.

Uma opacidade total não permitiria à nossa experiência visual ser mediada através do vidro. A placa de vidro em si seria transformada de meio para objeto da experiência. Ela seria o término da mirada visual. Apenas quando ela permanece ao menos parcialmente transparente é que pode ser tomada em nossa visão de modo tal que possamos ver através e para além dela. Entre a total opacidade e o mais alto grau de transparência existem muitas outras possibilidades, e estas possibilidades devem todas ser transformações mais agudas sobre qualquer outra forma prévia de ver o mundo com os olhos desarmados. Uma vidraça pintada transforma a coloração do panorama, uma vidraça com polaroide transforma a luz e apresenta relações junto ao panorama, etc. Pode-se imaginar aqui uma variedade não diferente daquelas multiplicidades de estilos de pintura e suas variações sobre a paisagem. A analogia não ocorre sem as nuances do mundo cientificamente e tecnologicamente incorporado no qual habitamos. Ao variar-se a coloração na sombra, ou fazendo as sombras azuis ou verdes em vez de cinzas (tal como os impressionistas na arte), nós aprendemos a enxergar diferentemente. $\mathrm{O}$ mesmo ocorre nas variações científicas contemporâneas com "cores falsas" ou por fotografia infravermelha. Nós aprendemos algo novo do mundo físico por meio de tais diferenças, e há "verdade" em cada variação.

Vamos continuar, no entanto, junto à trajetória que varia apenas no âmbito da transparência incolor. Nossa janela de vidro pode conter algumas pequenas curvas e superfícies desiguais, tal como as velhas janelas de vidro das casas de New England. Em tal caso, nossas visões mediadas ou nuas poderiam variar em distorção. Então, em algum lugar na história do século XI, alguém descobre que certas curvas ampliam o que é visto, e as lentes foram inventadas. Ampliação, uma vez descoberta, sugere uma nova trajetória. Se uma pequena ampliação mostra algo como sendo "maior", o que uma maior ampliação poderia mostrar? Aqui o exame deve seguir lentamente porque há muito que pode ser perdido pelo próprio rubor inicial de uma fascinação com as possibilidades tecnológicas.

O emprego das primeiras lentes foram lentamente adaptadas para o uso mais familiar que fazemos delas hoje, monóculos (século XIII), ou óculos, que no século XX se tornaram lentes de contato e até mesmo lentes implantadas numa incorporação ainda maior. Mesmo no século XIII não havia apenas monóculos, mas mesmo lentes compostas e um tratado sobre lentes (VITELLIO, 1270). Os óculos, que mais tarde pareceriam apenas uma relativamente pequena 
ampliação, demandam uma breve consideração inicial: primeiramente, eles são ainda melhores exemplos da relação (eu-vidro)-mundo do que a placa de vidro. Em uso, nós dificilmente nos damos conta deles; eles se distanciam e se tornam a transparência pela qual nós vemos o mundo. Mas, tal como o martelo de Heidegger, eles podem se tornar notáveis por estarem ausentes, por estarem quebrados, ou por não mais servirem ao propósito tal como a prescrição apropriada. Todos esses casos são uma obstinada obstrução funcional. Então, o significado dos óculos muda de meio a objeto da experiência.

Na capacidade de ampliação dos óculos, há, de certa forma, a "intencionalidade" tecnológica. A ampliação seleciona o panorama em certo sentido, e no processo há uma mudança tanto do tempo quanto do espaço. Minha visão tal como é ampliada enxerga como tal. E quando uma nova prescrição é dada, a pessoa precisa reaprender a usar sua visão através da lente a partir dos pequenos ajustes que foram feitos, e isto pode ser vivenciado mais dramaticamente quando alguém usa lentes muito mais fortes do que as necessárias. Aqui a variação de uma atividade motora normal é bem mais marcada.

Isso ocorre porque toda a nossa visão tal como é também é uma visão $a$ partir de; e a transformação da visão através das lentes muda, mesmo que sutilmente, nosso senso de espacialidade corpórea. O que antes era longe, agora é próximo; e quando a mobilidade é envolvida, isto requer um novo ajuste. A mais radical dessas variações é o bem conhecido experimento de inversão das lentes no qual aquele que vê enxerga o "mundo" de ponta cabeça. São necessários vários dias para que o agente da visão reaprenda sua forma de interagir tal como o mundo pareça estar "certo" novamente, mas ele parecerá.

A fisiologia tem uma dificuldade responsável por este fenômeno. Uma fenomenologia mais orientada pela forma reconhece que eu sou certa constelação de relações junto ao mundo e que esta constelação é aprendida e reaprendida dinamicamente. Estar em pé ou de ponta cabeça são relatividades junto ao contexto da mobilidade corpórea, tal como Merleau-Ponty já apontou.

O espaço corpóreo da visão se aplica até mesmo para situações menos motoras e pode ser notado em observações fixas. Existe até mesmo um sentido no qual nossa descrição usual sobre aquilo que a ampliação faz seja errado. Nós dizemos que o microscópio faz o microscópico "maior", mas isto é apenas em uma relação comparativa entre o que nós vemos com o olho desarmado e o que é visto por meio do microscópio. Colocado de maneira mais fenomenológica, o que muda é o sentido de distância ou proximidade para com o objetivo da visão. 
O paramecium visto através das lentes não é maior ou menor em meu campo visual do que outras coisas que eu coloco perto do meu nariz; mas eu, em um sentido corpóreo parcialmente irreal, estou agora "mais perto" do paramecium. O que eu tomo como meu "real" ou espaço corporal desarmado é transformado através do microscópio. Esta transformação da corporeidade espacial é notável, mas menos dramática no caso dos óculos. Porque os óculos são mais usados para corrigir a visão, para retraduzir o mundo turvo em outro distante e claro, e nós alegremente o aceitamos. Mas a mudança não é sem custo para aquele que não prefere ver o mundo claramente sem eles? Simultaneamente com o novo mundo corrigido, existe sua redução. Existe, por exemplo, o preço muito pequeno de carregar o equipamento em si para nossa mediação: agora eu preciso ter cuidado com os meus óculos ou minhas lentes de contato e com toda a parafernália que os acompanha. Mais ainda, particularmente com os óculos, meu mundo agora me é dado enquadrado, invadido, talvez quase imperceptivelmente, com os reflexos que ocorrem, com a poeira ou com as manchas de água que se acumulam e com a remota consciência de que o mundo visto através das lentes é, mesmo que levemente, modificado. Com lentes de contato, que estão ainda mais próximas do meu corpo, a situação é aprimorada e tais efeitos colaterais como reflexos ou enquadramentos desaparecem, mas, novamente, ao custo de uma nova "invasão" tátil ou pelo contato do meu corpo que as lentes trazem (porções do anteriormente imperceptível pó agora são tacitamente ampliados como irradiações, etc.), ainda que poucas pessoas que necessitem óculos parem de pagar este preço. Mas para cada transformação reveladora existe simultaneamente uma ocultadora transformação do mundo, que é dada através da mediação tecnológica. Tecnologias transformam a experiência, ainda que sutilmente, e esta é uma raiz de sua não neutralidade.

Pode-se suspeitar que se a trajetória rumo a uma maior ampliação é seguida e é latente na própria descoberta da lente, pode-se também esperar encontrar uma maior e mais óbvia estrutura de ampliação/redução à visão incorporada. Pelos nossos padrões, estes instrumentos primitivos foram relativamente pobres; mas eles ilustram ainda melhor o fenômeno da ampliação/redução.

Olhar através de uma lente mais poderosa é obter uma ampliação maior. O objeto visto parece estar mais perto, mais detalhado; minha posição corporal em direção a ela é simultaneamente colocada junto a uma grande sensação de quase proximidade. $\mathrm{O}$ objeto também é trazido mais focado para o centro da minha visão, ainda que esta proximidade seja simultaneamente acompanhada 
por mudanças que reduzem outros aspectos do objeto que é visto. Por exemplo, quanto maior for a ampliação, quanto mais fino for o plano focal, então o senso de profundidade se perde ao passo que a ampliação aumenta. Assim é a extensão e localização do objeto em seu próprio ambiente. Ver a lua através de um telescópio é vê-la mais próxima, mas também é perdê-la em sua posição no céu. Tecnologias de lentes transformam o próprio senso de espaço que eu vivencio, numa modificação significativa igualmente do espaço corporal e do mundo. Ela transforma o "mundo" numa espécie de irreal, achatando-o e estreitando-o. Seu distanciamento é sempre uma forma peculiar de distância-proximidade. Mas nós "esquecemos" disso ao passo que aprendemos a incorporar a tecnologia no âmbito de nossas ações familiares.

A despeito dessa redução, a qual é perceptível, continuamos a seguir a fascinante trajetória da mais dominante dimensão da ampliação da visão incorporada. Virtualmente é possível contemplar a redução em si e aqui repousa outro segredo para a saída de Adão do Jardim: o que a ampliação mostra, ao passo que se torna mais forte, é genuinamente novo, não descoberto. Ser visualmente incorporado através das lentes é adentrar em macro e micromundos que eram anteriormente desconhecidos, e isto se dá tecnologicamente.

Eu estive descrevendo fenomenologicamente a visão tecnologicamente incorporada, a visão do mundo mediada através de variações sobre a ótica, uma ótica simples e até primitiva comparada à diversidade da ótica no final do século XX. Latente nos nossos primeiros movimentos a partir do Éden, já se encontravam diferentes formas de visões de mundo. No âmbito do contexto das simples tecnologias óticas, pode-se reposicionar a figura paradigmática de Husserl usada para a sedimentação da ciência moderna: Galileu.

Nos últimos anos, tem aparecido uma infinidade de livros sobre Galileu, muitos dos quais debatem os assuntos tradicionais sobre a teoria em relação à experimentação. Eu não devo entrar nestes debates, mas, ao invés disto, tomar dois outros temas interpretativos que correspondem ao mundo da vida e à ênfase perceptual desta investigação. Talvez Husserl demonstrou primeiro, antes de Kuhn, como Galileu tornou um novo paradigma da ciência possível.

O Galileu de Husserl descobriu a matematização indireta do universo, mas neste processo também originou o grande esquecimento do mundo da vida, o qual Husserl posiciona à porta do renascimento de Galileu de uma antiga depreciação dos sentidos. Galileu, antes de Descartes, distinguiu entre qualidades primárias, qualidades que estavam nos ou pertenciam aos objetos, e secundárias, 
que estavam localizadas no sujeito ou observador, fazendo assim certas qualidades "objetivas" e outras "subjetivas". Essa doutrina, ainda não inteiramente apagada da ciência sedimentada, é pré-fenomenológica. Onde quer que estejam localizadas, extensão em forma e formas coloridas estão igualmente presentes para a experiência microperceptiva; a organização sistêmica da percepção, porém, tal como as histórias da percepção de Michel Foucault têm demonstrado, é altamente variável. O próprio Galileu fez esta organização epistêmica clara:

Tão logo eu formo uma concepção da substância material ou corpórea, simultaneamente eu sinto a necessidade de conceber que tal concepção possuir limites de alguma forma ou de outra; esta relatividade aos outros, se é maior ou menor; se esta neste ou naquele lugar, neste ou naquele tempo; se está em movimento ou repouso; se esta ou não em contato com outro corpo; se é única, rara ou comum; e nem por qualquer ato de imaginação eu posso dissociá-la de tais qualidades. Mas eu não me encontro completamente compelido a apreendê-la como sendo necessariamente acompanhada por tais condições tal como se deve ser branca ou vermelha, amarga ou doce, sonora ou silenciosa, com odor agradável ou desagradável; e se os sentidos não demonstrarem estas qualidades; linguagem e imaginação por si mesmas jamais chegariam até elas. Desta forma eu penso que estes gostos, cheiros, cores, etc., no que diz respeito ao objeto no qual eles aparentam residir, não são mais do que meros nomes. Eles existem apenas no corpo sensitivo. ... Eu não acredito que exista nada fora dos corpos que excite gostos, cheiros e sons, etc. exceto tamanho, forma, quantidade e movimento. ${ }^{2}$

Aqui nós temos a notória doutrina do sujeito/objeto e das qualidades primárias e secundárias. Hoje é fácil desconstruir esta episteme arcaica, ao ver através dela, como ela era.

Como Husserl viu, é do isolamento de um conjunto de possibilidades perceptivas, aquelas localizadas nas metafísicas geométricas, que se forma a episteme da ciência moderna inicial. Agora é fácil de ver que Galileu não foi muito cuidadoso com a interface entre imaginação e percepção. Ver é de fato ver junto a um campo de algum conjunto de formas correlatas, extensões e corpos, mas apenas quando se volta para as variações imaginativas é que tais formas podem ser modificadas. Na imaginação, o quadrado poderia muito bem ser um círculo ou um amontoado amórfico e caótico de bolhas. A percepção não pode eliminar 
a cor; mas, novamente, quando a imaginação entra em cena, pode-se sempre presenciar algo em cores diferentes das que estão ali. (Eu poderia argumentar, no entanto, que não existe tal coisa como uma imaginação visual incolor, embora o campo de fundo da imaginação visual possa ser colorido por alguma cor distinta). Se isto é assim, então, as variações imaginativas sobre forma de qualquer objeto particular podem ser indefinidamente reformuladas imaginativamente, ainda que qualquer que seja a forma, existe uma forma-presença junto à presentificação visual. E o mesmo se aplica às cores. E mesmo que a cor da coisa varie, ao extremo do aparentemente incolor ou transparente objeto, resta ainda a mesma constância da cor-presença. O fundo, entretanto indistintamente colorido (cinza, sombreado, etc.), permanece uma constante cor-presença. Microperceptivamente, ao menos, nenhuma das qualidades secundárias nunca está ausente como qualidades do pleno. Isola-se, então, extensão geométrica numa abstração especial ou ato redutivo ao qual é dado o status de "preferido", tal como Husserl reconheceu. Assim, Galileu teve que tomar como sendo sua seleção, por um ato de abstração, um conjunto favorito de qualidades e deslocar as outras para, assim, obter o seu "mundo" geométrico.

Galileu substitui, para parte do pleno sensório do mundo da vida microperceptivo, sua seleção de uma abstração do "mundo" geométrico. Este movimento torna possível uma nova aquisição, mas, simultaneamente, encobre outra mais antiga. Se Husserl está certo, como se pode recuperar não o que Galileu diz sobre sua visão, mas sua relação secreta daquela visão que abre caminho para seu novo "mundo"? A resposta, eu asseguraria, repousa numa reinterpretação histórica sensitiva não do que Galileu diz sobre sua teoria, mas sobre o que deve ocorrer ao nível da práxis. Para isto eu troco Galileu de Husserl para Galileu de Derek Price; no Galileu de Price encontra-se a ciência em íntima proximidade ao continuum ótico e suas estruturas fenomenológicas.

Price reforça o papel do telescópio para a práxis de Galileu. Ele nota que, independentemente da ciência como tal, o emprego da lente tinha chegado ao ponto em que as lentes eram fortes o suficiente para que mesmo a diminuição fosse possível. Ele sustenta que existe uma ligação forte e espontânea entre filosofia da ciência e história da tecnologia. Tal ligação é o desenvolvimento atual da instrumentalização:

O arquétipo deste fenômeno é o mais antigo causador de uma ruptura, nomeadamente, o uso do telescópio por Galileu. Sob o ponto de vista da história da tecnologia nós podemos ver que o telescópio se tornou 
possível quando o componente crucial das fortes lentes de diminuição se tornaram comumente disponíveis durante o final do século XVI. A produção de lentes tinha sido um ofício honrado e comum para a fabricação de óculos no final da Idade Média; mas as lentes para pessoas míopes foram fruto de um desenvolvimento tardio, e os óculos com uma capacidade muito forte de diminuição tinham muito pouca utilidade comercial. ${ }^{3}$

O argumento de Price, uma versão sobre o lema histórico de que o motor a vapor tem mais a ver com o desenvolvimento da ciência do que com motor a vapor, demonstra o uso inicial de tais lentes fortes num domínio outro que não a ciência, tal como: "Na Renascença, com a preocupação sobre a perspectiva dos artistas e outras ilusões, sob tal perspectiva os óculos atraíram interesse, desde que eles mostravam o mundo em miniatura como um microcosmo." 4

Isto ecoa a observação de Michel Foucault de que a Renascença estava mais preocupada com o espetáculo do que com a ciência em si. Mas a própria prática de criar perspectivas junto aos óculos primitivos teve que ter sido tomada junto à ciência. O que precisa ser levado em conta é que o modo de ver que era ver através destes óculos é parte de um paradigma familiar ao tempo de Galileu. E o mesmo se aplica à presença das lentes.

$\mathrm{O}$ uso de lentes era comum, um fenômeno tido como certo. Era parte do cotidiano do mundo de Galileu, o macroperceptivo mundo da época. Mais ainda, existe uma relação estrutural, epistêmica, entre a fascinação da Renascença com o microscópio e perspectivas e o mundo geométrico que Galileu ajudou a transformar em uma visão de mundo. A perspectiva renascentista, uma das várias formas para se representar a espacialidade, já era em si "geométrica”. Isto é dizer que tal modo de ver as coisas já era parte do mundo da vida no qual Galileu estava localizado. Não se trata apenas de uma forma de visão, mas uma práxis.

Price observa que o tipo de fascinação com lentes usadas para a produção de poderosas lentes de diminuição foi a base para o uso posterior que Galileu fez dos telescópios. De fato, o primeiro uso não foi totalmente desenvolvido para os propósitos de Galileu. Os primeiros telescópios foram desenvolvidos por fabricantes de lentes flamengos e havia igualmente microscópios e telescópios compostos no tempo de Galileu. Não diferentemente das tecnologias nos

3 PRICE, Derek de Solla. "Notes Towards and Philosophy of the Science/Technology Interaction," in The Nature of Technological Knowledge: Are Models of Scientific Change Relevant? ed. Rachel Laudan. Dordrecht: D. Reidel Publishing Co., 1984, p. 106-107.

4 Ibid., p. 107. 
nossos dias, no entanto, as esperanças comerciais dos desenvolvedores eram primeiramente direcionadas para o melhor uso comercial de seu produto: o militar. Price observa que, "como tecnologistas, os fabricantes de lentes tentaram vender sua invenção como um dispositivo militar ao Pentágono mais rico do seu tempo. Eles estavam equivocados, tal como inventores usualmente estão, sobre a utilidade de seu invento. Isto se deu anos antes do telescópio ser usado para a guerra, mas apenas para a sinalização em vez de servir para a espionagem." ${ }^{5}$

De acordo com Price, nem mesmo Galileu inicialmente fez uso deliberado de seu telescópio para seu propósito eventual. Novamente num vislumbre marcante da versão neomoderna da combinação ciência-indústria-governo:

Quando Galileu duplicou o dispositivo, ele não tinha ideia de que o mesmo seria de muito mais valia para ele próprio do que uma simples forma de ganhar alguma comissão dos patrões Médici. O telescópio de Galileu tinha um campo de visão tão refinado que ver através dele por dois buracos de fechadura em conjunto jardas de distância não seria difícil. ${ }^{6}$

Ainda que ele tenha olhado através dele, mesmo com sua já seletiva visão, a macrovisão da seletividade geométrica e perspectiva, Price argumenta:

Mesmo que provavelmente Galileu tenha visto apenas a Lua em sua primeira noite e que talvez não tenha muito mais do que se divertido ao ver a ilusão de que a Lua parecia como se tivesse montanhas nela ao invés da face de uma na Lua A ideia brilhante o atingiu apenas quando ele olhou novamente alguns dias depois e viu que as sombras das montanhas ilusórias agora pareciam completamente diferentes do modo como pareciam antes. Galileu sabia o suficiente de astronomia para se dar conta que uma conta rápida seria o suficiente para ele calcular o peso daquelas montanhas. Ele levou adiante os cálculos e descobriu que elas eram do mesmo tamanho que as montanhas da terra e isto deu a ele o que em alguns momentos é chamado de "click"; tudo fez sentido. Ele sabia que as montanhas eram reais e não ilusão. Ele sabia que pela primeira vez na história e havia visto algo que não poderia ser atestado pelas experiências comuns dos sentidos. ${ }^{7}$

5 Ibid., p. 107.

6 Ibid., p. 107-108.

7 Ibid., p. 108. 
Em suma, aqui nós descobrimos, por aproximação, a macrovisão seletiva de Galileu e sua nova micropercepção. O domínio das sombras, das medições e dos ângulos dera a Galileu os meios para ver as montanhas da lua em distância similar àquelas da terra. Mas, contrariamente à sua depreciação dos sentidos, foram também as sombras coloridas (que se todas fossem "qualidades secundárias" teriam sido invisíveis?) que tornaram as medições possíveis. A visão, embora já no secretamente favorito "preto e branco" no pensamento da geometria moderna inicial, enquadrava o pleno em uma nova maneira. Aqui se encontra uma mudança dramática de paradigma junto à visão, mas esta é uma mudança paradigmática igualmente perceptiva e que envolve tecnologia. A tecnologia do telescópio possibilitou a mudança da percepção em si.

Price argumenta que aqui repousa a pista para a junção entre filosofia da ciência e a história da tecnologia. Mudanças de paradigmas não são simplesmente apenas revoluções intelectuais. Na minha terminologia, elas são também novas formas nas quais a visão científica pode ser incorporada. Price estende sua argumentação:

A magnitude desta descoberta não pode ser subestimada. Que a Lua tinha montanhas foi uma descoberta importante, mas ofuscada a uma relativa trivialidade quando comparada com a natureza do experimento em si. Galileu concluiu que ele havia manufaturado para si mesmo um conhecimento revelador do universo que fez do seu pobre cérebro mais poderoso que o de Platão, Aristóteles e de todos os Padres da Igreja somados. O princípio da revelação artificial foi o que foi ao ponto de preocupar a Igreja sobre o comportamento para além dos limites da tolerância e do aceitável para um Católico devoto. ... Seu pequeno tubo com lentes vestiram o olho nu, permitindo-o exceder toda a experiência humana anterior. ${ }^{8}$

A saída de Galileu do Éden foi dramática. Ela tomou a forma de uma ciência incorporada tecnologicamente em contraste - e muito além - ao que foi alcançado pela ciência dos gregos antigos. Equipamentos para a medição, incidentais para a ciência grega, vieram a ser um dos fatores centrais num novo conjunto de relações perceptivas do que se tornaria um grande mundo em expansão.

$\mathrm{O}$ que Galileu viu ele não havia previsto e nem buscado. Ele viu um novo mundo astronômico que incluía não apenas as montanhas da lua, mas as fases

8 Ibid., p. 108-109. 
de Vênus, os satélites de Júpiter e as estrelas mais distantes e mais numerosas do que as disponíveis para o olho nu. Price observa, novamente em um ato de antecipação do status moderno do aspecto da propensão da ciência à publicidade, que Galileu imediatamente começou uma campanha para fazer conhecidas as suas novas descobertas. Mas mais importante: o que a revelação artificial de Galileu através da ótica alcançou foi uma forma de fazer da nova ciência mais simples e mais imediata pela via perceptiva do que por meio de cálculos.

Saindo da mudança tecnológica para a científica, vamos considerar a natureza das observações atuais de Galileu e seus efeitos sobre a teoria. Claramente, desde que ele não sabia o que esperar, ele não pode iniciar as suas observações com o propósito de testar a teoria de Copérnico.... [Mas, uma vez vistas,] estas imagens inesperados, de uma inquestionável realidade [percebida], fez-se óbvio quase sem argumentação e certamente sem matemática que o universo era copernicano. ${ }^{9}$

Price salienta o bem-conhecido fato de que, com base na teoria e simplicidade eficiente, Copérnico foi, efetivamente, não mais capaz de dar conta matematicamente do movimento estelar do que Ptolomeu, mas com as novas observações tecnologicamente incorporadas ajudar a resolver este caso. Assim, para além de qualquer coisa que Husserl possa reivindicar, Galileu também alcançou um novo e tecnologicamente mediado paradigma para a visão científica:

Voltando a Galileu, há pouca dúvida de que o retumbante sucesso do telescópio ... compartilha da nova forma de fazer filosofia que se dá pelas revelações artificiais ao invés do poder do cérebro. ... Ele "observou a Natureza nua" e aprendeu a partir da experiência que isto poderia ser feito de novo e de novo. Seu insight foi que o novo auxílio aos seus sentidos poderia ser generalizado para outras experiências; isto mudou o pensamento para a Nova Filosofia da ciência experimental. Isto não foi o teste de teorias, mas a tentativa de novas técnicas para ver o que elas poderiam fornecer, esperando pelo inesperado. ${ }^{10}$

O que Galileu diz sobre seu método de observação é obtido por aquilo que ele $f a z$ na situação observacional. Pelo menos, a descoberta da revelação artificial tão significante quanto a indireta matematização da natureza.

9 Ibid., p.109.

10 Ibid., p. 110. 
Embora não seja tão radical quanto a afirmação de Heidegger, Price enxerga a tendência em enfatizar o teórico sobre as condições materiais como sendo a origem de certas concepções equivocadas acerca da ciência em si. Ele argumenta que o que temos denominado de o modelo nomológico de interpretação assume a função de experimento a ser confirmado pela teoria. Aqui está um exemplo concreto de como a instrumentação ocupa um papel secundário e aplicado junto ao velho paradigma. Price localiza esta tendência a minimizar o papel dos instrumentos como uma característica do tipo específico de episteme associada com a velha filosofia da ciência.

Eu sugiro que esta infeliz posição... evoluiu a partir do que agora me parece uma linha principal equivocada dentro da filosofia da ciência na qual se supõe que a função da experiência científica consiste em testes de hipóteses e teorias. Esta suposição originada num período atípico no início do século XIX quando experimentos com eletricidade e magnetismo eram comuns, e ele continuou a florescer porque aqueles que tiveram sua experiência de ciência obtida em livros ao invés do banco de laboratórios naturalmente consideram a história da ciência como se fosse um empreendimento intelectual, puro e simples. ${ }^{11}$

Price argumenta que é muito mais o processo de revelação artificial que se encontra na articulação entre ciência moderna e tecnologia que cria as condições para subsequentes mudanças de paradigmas.

Cada inovação radical nesta tradição artesanal dá origem não para o teste de novas hipóteses e teorias, mas sim para a prestação de nova informação que afeta o que as teorias científicas devem explicar. Este processo, que eu descrevo como "revelação artificial", está na origem de muitas mudanças de paradigmas, talvez não de todos, mas da maioria. ${ }^{12}$

Em suma, nova instrumentalização proporciona novas percepções, as quais, num contexto kuhniano, vai ser minimamente a fonte de novas possíveis anomalias. Mas mais fortemente, esta nova e agora necessária ligação da instrumentalização entre ciência e tecnologia é em si a extensão da visão científica que vem a ser a forma de todo um novo contexto. 
Este foco sobre o desenvolvimento da instrumentalização, que Price toma como sendo o conector entre a filosofia da ciência e a história da tecnologia, sugere outra nova interpretação do papel da tecnologia na ciência. Se Price está certo, pode-se facilmente ver que não só são alegações epistêmicas negativas de Galileu sobre os sentidos na melhor heurística, mas que sua própria experiência tem uma nova forma em um novo arranjo das próprias qualidades primárias $e$ secundárias como mediadas por tecnologias de observação. Isto leva Price a dizer:

Eu alego uma considerável vantagem sobre a descrição de Kuhn das revoluções paradigmáticas e da interpretação do filósofo da ciência sobre o experimento como sendo um servo para testar teorias. Eu acredito que a história da produção da ciência experimental é o elo perdido entre a história da tecnologia e a da ciência. ${ }^{13}$

O mesmo insight vem de uma fenomenologia da visão incorporada.

O que as instrumentações perceptivas fazem é colocar o observador em todas as novas posições no que diz respeito ao universo, seja aos níveis macro ou micro. $\mathrm{O}$ espanto ocasionado pelas descobertas iniciais de Galileu é recorrente na astronomia. Apenas neste século muitas novas anomalias e variados novos fenômenos têm sido "vistos". Mais ainda, muito da astronomia moderna deve sua profunda penetração a um conjunto de dimensões múltipla-sensitiva adicionado. Radiotelescopia, um ouvido "artificial" instrumental, começou a "ouvir” há algumas décadas algum tipo de atividade estelar nas áreas até então "escuras" ou "vazias" dos céus. Esta revelação artificial é a versão high-tech de uma experiência muito mais ordinária de ouvir algum ruído no escuro, que apenas depois é então visualmente identificado (talvez com a ajuda de uma lanterna). Não é apenas nova teoria que nos separa de nossos antepassados, mas também a nova percepção ampliada que acontece através da incorporação instrumental. Para ancorar o fato inversamente, tire fora toda a instrumentalização da comunidade científica e pergunte se seria possível saber. Seus limites seriam rapidamente reduzidos justamente àquelas admiráveis, mas na melhor das hipóteses, noções especulativas, de nossos antepassados gregos.

A descoberta de Galileu, então, não foi apenas a indireta matematização da natureza, mas também, seguindo a noção de Price, a artificialmente adicionada 
percepção da natureza. Sua percepção, incomensurável em relação a qualquer dos antigos padres da Igreja, estava na vanguarda da nossa tradição da ciência moderna tecnologicamente incorporada que caracteriza o nosso tempo.

Se o foco que está no centro da nova ciência de Galileu é a percepção incorporada por revelação artificial, o campo no qual ela ocorre é no âmbito de um mundo da vida (lifeworld).

Os historiadores Price, Lynn White Jr. e, anteriormente, Lewis Mumford nos deixaram sutilmente muito mais cientes da rápida acumulação das tecnologias "modernas" que, primeiro a Renascença, e depois os primeiros cientistas modernos tomariam como certos. Mas esta consciência também pode ser prenunciada por um atento olhar fenomenológico sobre aquilo que repousa latente na práxis, em macropercepção cultural.

Observe, inicialmente, algo sobre a textura da vida tecnológica do século XVII. A enorme extensão de invenções é impressionante.

Ótica, que levou à percepção astronômica e depois microcósmica dos anteriormente insuspeitados aspectos do universo, começou já no século XI. Tecnologia relativa à ótica era comum em óculos nos idos do século XII, e lentes foram compostas para telescópios e microscópios por volta do século XVII.

Havia maquinaria, mais frequentemente para a madeira do que para o ferro para grandes obras, menores no caso do ferro, que bem antecipa o advento da ciência moderna. As terras baixas foram drenadas; as catedrais foramconstruídas; havia enormes guindastes, elevadores, moinhos de vento e de água, todos comuns a partir do século XIII em diante. Nem devemos esquecer-nos do frequentemente primário emprego das tecnologias, o militar. Canhões apareceram no século XII e eram sofisticados no tempo de Galileu; e rifles enquanto armas de fogo já estavam em uso. Existia até mesmo o taxímetro. Em suma, a textura tecnológica da Europa pós-medieval era impressionante. Era parte da vida cotidiana de, ao menos, todo cidadão urbano.

Ademais, tal textura foi enriquecida pela exploração e pelo comércio, que iniciou antes da descoberta do Novo Mundo por Colombo. Ouro e especiarias afluíam para a Europa durante muitos séculos antes de Galileu ter visto o lustre como um pêndulo. Tal era o relativamente sofisticado tecnológico mundo da vida da alta Renascença. Um olhar sensível para o tempo de Galileu apresenta a impressionante matriz das tecnologias já comuns, mas também sugere que esta infraestrutura disponível adquiriu a forma de vida comum. 
A matriz, no entanto, é muito complexa para demonstrar imediatamente a práxis que se tornaria concentrada no nascimento da ciência. Eu devo me voltar para um campo mais estreito de análises. O que Price chama de revelação artificial e eu denomino visão incorporada tomou forma em muitos lugares. $\mathrm{O}$ visualismo da Renascença, eu sugiro, embora preceda historicamente o uso que Galileu faz dele, já estava bem consolidado como sendo o sentido privilegiado; ele havia se transformado a partir das perspectivas artísticas e teatrais da Renascença na ciência moderna. As "leis da perspectiva” já eram interpretações geométricas de profundidade. Isto era sabido por volta de 1440. E Leonardo da Vinci, que foi muito mais engenheiro do que um cientista teórico, já havia transformado uma velha anatomia tátil em sua anatomia visual e artística. A fascinação não com o microcosmo, mas com a posição de observação sob a perspectiva do voo do pássaro ${ }^{14}$ era virtualmente bem difundida como sendo a perspectiva dominante dos séculos XV e XVI. Em suma, a redução da micropercepção para uma posição preferida de visão já havia começado. Além disso, o modo como os artistas olhavam os espaços geométricos tinha preparado o terreno para a modificação inicial da visão. Galileu pode tomar como sendo verdadeiro na já estabelecida modelagem da percepção.

Para obter um ponto de vista mais preciso, no entanto, examinarei algumas tecnologias especiais, particularmente como elas se relacionam com os sentidos e com a percepção do espaço e do tempo. Começarei com a percepção do tempo e as tecnologias relativas ao relógio e seu papel no mundo da vida.

\section{A. Técnicas do Mundo da Vida: percepção do tempo}

Uma famosa passagem da filosofia do tempo de Santo Agostinho precede a era da cultura do relógio: "O que, então, é o tempo? Se ninguém me pergunta, eu sei; mas se eu tento explicar isso para alguém, então eu não sei." Esta afirmação implica algo como uma forma intuitiva de acesso direto, mesmo que inefável, ao tempo. Ainda que o mundo da vida seja cheio de indicadores da percepção do tempo, que nas culturas modernas são predominantemente relógios.

O relógio é reconhecido há muito tempo como uma importante tecnologia para o Ocidente. O capítulo de Lewis Mumford em Técnica e Civilização sobre "O Monastério e o Relógio" (1934) é provavelmente uma das melhores

14 Nota do Tradutor: Toda perspectiva (cônica ou paralela) que adote o observador muito acima da linha do horizonte como se estivesse a mirar o chão, é chamada de voo de pássaro ou olho de pá-ssaro. 
exposições conhecidas sobre a relação entre a tecnologia e uma forma de vida. Ele argumenta:

\begin{abstract}
O relógio, não o motor a vapor, é a máquina chave para a moderna era industrial. Para cada fase de seu desenvolvimento, o relógio é igualmente o fato marcante e o típico símbolo da máquina: mesmo hoje nenhuma outra máquina é tão ubíqua. Aqui, na gênese das técnicas modernas, apareceu profeticamente a precisa máquina automática que, apenas depois de séculos de esforço posterior, serviu também para provar a consumação final destas técnicas em cada departamento da atividade industrial. ${ }^{15}$
\end{abstract}

A exposição de Mumford primariamente relaciona o relógio a uma mudança do tempo social. Primeiro, no monastério, o relógio regula o movimento social, fazendo-o igualmente melhor ordenado e mais uniforme. Os primeiros relógios usados nos monastérios serviam apenas para dizer as horas. Estas, por sua vez, regulavam as horas de trabalho e devoção dos monges. Mumford nota que isso também mudou nossa percepção de tempo, ao menos em contraste com as culturas que não fazem uso do relógio. Tal mudança aumenta a quantificação. "A aplicação dos métodos quantitativos de pensamento para o estudo da natureza apareceram primeiro na medição regular do tempo; e a nova concepção mecânica do tempo surgiu em parte no âmbito da rotina do monastério."16

O mesmo argumento foi apresentado antes ainda, por Martin Heidegger em Ser e Tempo (1927). Tal como acontece com as ferramentas para ele, tecnologias "levam em conta" a natureza em certo sentido. A plataforma coberta da ferrovia leva em conta o clima chuvoso; a iluminação, da escuridão; e o relógio, dos ritmos do tempo. Tempo, Heidegger aponta, é um fundamento da existência. Ele é baseado no senso humano de finitude, e a contagem do tempo é a contagem sobre aquilo que se pode fazer com o tempo de finitude; também, a temporalidade surge da pré-ocupação. Isto, ele argumenta, define igualmente as culturas que fazem e as que não fazem uso do relógio, mas em ambos os casos o tempo é figurado em relação ao que humanos concretamente encontram no mundo. Nas culturas sem relógio, estes são fenômenos primários tal como o surgir e o pôr do sol e o movimento das estações. Existe uma analogia quase natural entre

15 MUMFORD, Lewis. Technics and Civilization. New York: Harcour, Brace and Co., 1962, p. 14. 16 Ibid., p. 12. 
o movimento natural e o relógio. "E porque a temporalidade na qual o Dasein deve ser tomado em seu tempo é finito, seus dias já estão contados." ${ }^{17}$

Agora nós notamos como Heidegger toma o reino dos equipamentos como sendo aquilo que é próximo da vida cotidiana. O mesmo se aplica aos relógios. Para o jovem Heidegger, relógios são baseados na temporalidade existencial. “Temporalidade é a razão para o relógio. Como sendo a condição para a possibilidade que o relógio é factualmente necessário, temporalidade é como a condição para que possa ser descoberto." ${ }^{18} \mathrm{O}$ tempo de Heidegger, paralelamente ao tempo de Mumford, é também um tempo social. O tempo é intencional de modo que ele é sempre direcionado; é tempo para , tempo-em-relação$-\mathrm{a}$ , tempo para o qual, etc. "Apenas agora, em todo caso, pode o tempo com o qual nos ocupamos ser completamente caracterizado por sua estrutura; ele é datável, mensurado e público; e por ter tal estrutura, ele pertence ao mundo em si." ${ }^{19}$ Nesse sentido, relógios apontam de maneira reflexiva novamente para uma base existencial primitiva.

Relógios, no entanto, uma vez desenvolvidos, transformam a percepção do tempo. Por exemplo, a medição em si se torna uma atividade focal possível. Relógios são a condição para fazer tais medições mais explícitas, mesmo se fundadas sobre a temporalidade existencial. Mas com a emergência da medição que leva em conta sua própria trajetória de possibilidade, relógios também podem, junto ao enraizamento social, abrir o caminho para a separação do tempo social da cultura sem-relógio:

Comparações apontam que, para o Dasein "avançado", o dia e a presença da luz solar não mais possuem aquela função especial tal como possuem para o Dasein "primitivo" sobre o qual a nossa análise do cômputo do tempo natural foi baseada; pelo Dasein "avançado" ter a "vantagem" de mesmo ser capaz de transformar a noite em dia. Similarmente, nós não mais precisamos olhar explícita e imediatamente para o sol e sua posição para determinar o tempo. A própria fabricação e uso de equipamentos de medição permite ler o tempo diretamente por um relógio produzido especialmente para este propósito. ${ }^{20}$

Aqui está a temporal saída tecnológica do Jardim do Éden.

17 Martin Heidegger, 1962, p. 466.

18 Ibid., p. 467.

19 Ibid., p. 468.

20 Ibid., p. 468 
O relógio não apenas muda o que é enfatizado na contagem do tempo, mas é uma aquisição do mundo da vida. Ele torna possível outros movimentos que diferem da percepção da contagem do tempo sem-relógio. Heidegger nota que a natureza é lida diferentemente via relógio: "Nosso próprio entendimento do relógio natural desenvolve-se com a descoberta da natureza e nos instrui assim para novas possibilidades de um tipo de medição do tempo que é relativamente independente do dia e de qualquer observação explícita do céu". ${ }^{21}$ Em termos heideggerianos, o relógio igualmente muda a variável em contagem do tempo (ele torna as medições em si um tema da dimensionalidade temporal) e abre o caminho para um tipo de autonomia que parcialmente distancia da "natureza". Galileu pode tomar ambas estas aquisições como garantidas. Elas já eram parte da forma de vida característica do mundo da vida do século XVII. Lynn White Jr., também apontou como o relógio foi central para a consciência do Ocidente, ainda mais especificamente para o Ocidente Latino. Ele nota que o relógio era assimilado de maneira bastante diferente na práxis cultural no Ocidente Latino em comparação com o Oriente Bizantino:

Em um prédio separado fora da Hagia Sophia, Justiniano colocou uma clepsidra e relógios solares, mas relógios nunca foram permitidos juntos a ou em igrejas orientais; coloca-los lá seria o mesmo que contaminar a eternidade com o tempo. No entanto, tão cedo quanto os relógios mecânicos foram inventados no Ocidente, eles rapidamente se difundiram não apenas para as torres das igrejas latinas, mas também para os seus interiores. ${ }^{22}$

Uma vez que o tempo pode ser percebido através da percepção do relógio, igualmente medidos e distanciados dos "relógios" naturais, tais como o sol ou a estação ou movimentos dos corpos celestes, pode-se também tomar o movimento mecânico como sendo paradigmático. De fato, compreender o movimento celeste como sendo um "relógio" é anacronismo, mas compreendê-lo é ou pode ser uma metáfora para o entendimento focando em si mesmo. E este movimento aconteceu cedo, muito antes da ciência de Galileu:

É nas palavras do grande eclesiástico e matemático Nicolas de Oresme, que morreu em 1382 como Bispo de Lisieux, que nós encontramos primeiro a metáfora do universo como sendo um vasto relógio mecânico

21 Ibid., p. 468.

22 WHITE JR, Lynn. “Cultural Climates and Technological Advance in the Middle Ages”, Viatot 2, 1971, p. 171. 
criado e colocado em movimento por Deus e assim "todas as engrenagens se movem o mais harmoniosamente possível”. Era uma noção com um futuro: eventualmente a metáfora tornou-se uma metafísica. ${ }^{23}$

Natureza em si foi assim lida como sendo um relógio, e sua ontologia assim interpretada, mesmo que o relógio tenha chegado mais tarde à cena. Nicolas foi muito rápido em adaptar sua metáfora-metafísica, desde que relógios com divisões em minutos e a perfeição do relógio mecânico têm sido datados em 1345 e 1370, respectivamente. Pode-se suspeitar que esta rápida fascinação pelo artefato humano esconde uma tentação que ainda persiste no final do século XX. Em nosso tempo, não apenas o universo, mas também nós mesmos somos lidos por meio de nossas tecnologias.

Essas observações preliminares são indicativas do papel difuso do relógio junto ao mundo da vida da ciência nascente. As fenomenologias implícitas da história e filosofia dos relógios podem ser feitas mais explicitamente. Primeiro: ler o tempo através de um relógio substitui o que é lido; lê-se o relógio ao invés dos céus. Mesmo que os ritmos da natureza não sejam totalmente abandonados, eles gradativamente tornam-se um pano de fundo em vez de possuir uma significância primária. Segundo: o tipo de movimento do relógio em si (até os recentes elétricos) toma uma forma diferente, uma forma notada desde o início; o movimento dos primeiros relógios era "irregular", pois se dava por saltos mecânicos. A descrição de Turing sobre uma máquina de estado finito, baseada nos movimentos discretos do relógio, o próprio modelo para o computador, se aplica muito bem para o relógio medieval:

[Máquinas de estado discreto] se movem por saltos súbitos ou cliques de um estado definido para outro. Tais estados são suficientemente diferentes para a possibilidade de confusão entre eles ser ignorada. Falando estritamente, não existem tais máquinas. Tudo realmente se move continuamente. Mas existem muitos tipos de máquinas que podem proveitosamente serem considerados como sendo máquinas de estado discreto. ${ }^{24}$

Relógios medievais progrediram através de mãos que saltavam de um instante para outro, e o mesmo movimento de salto ocorre nas atuais versões a quartzo.

23 Ibid., p. 125.

24 TURING, A. M. “Computing Machines and Intelligence”, Minds and Machines, ed. Alan Ross Anderson. Englewood Cliffs: Prentice Hall, 1964, p. 11. 
Oresme, nos anos 1300, fez a conexão entre os céus e o relógio; outro uso metafórico foi praticado por Galileu. Diz-se que ele usou, para medir o tempo em seus experimentos de aceleração, não um relógio, mas seu pulso. Mas ele já havia feito a conexão entre seu pulso e um relógio: ele lia seu pulso como sendo um relógio, indicando que o digital ou quantitativo já tinha começado sua forma de ler o tempo.

Terceiro: a precisão e regularidade do relógio, a despeito de sua analogia na metáfora da corrida harmoniosa das esferas, também contrasta com os movimentos celestes. De fato, uma vez que a regularidade do relógio se tornou instrumental igualmente nos níveis micro e macroperceptivos da medição científica moderna inicial, a própria descoberta das anomalias celestes se tornou possível. O movimento "perfeito" circular e regular como o de um relógio foi logo descoberto como não sendo o movimento dos céus. A descoberta de Kepler dos movimentos elípticos e as descobertas tardias de perturbações em movimentos planetários são anomalias em contraste com o movimento instrumental sugerido ou de fato instanciado pelos relógios. Aprende-se, nesse sentido, tanto pela diferença entre a "intencionalidade" instrumental quanto pelas similaridades que usualmente dominaram as aquisições iniciais do mundo da vida.

Igualmente, representações discretas e circulares do relógio contando teriam separado o Novo Adão de qualquer percepção monodimensional do Jardim; mas a separação nem é total e nem é sem a possibilidade de algum tipo de recuperação. Pode-se enxergar a olho nu os movimentos do sol e das estrelas, como muitos têm feito no século XX para propósitos especiais, mas uma vez que se deixou o Jardim as formas antigas de se obter conhecimento são mais frequentemente perdidas ou esquecidas. Pouquíssimos de nós "sabem" o que qualquer camponês teria conhecido sobre tempo de semeadura ou ter em conta com a mesma seriedade a passagem das estações. Nossa práxis irreversivelmente foi modificada.

Note, agora, muitos aspectos da percepção do tempo na leitura do relógio: a percepção do tempo através de um relógio é uma percepção hermenêutica. Se "lê" o relógio e, indiretamente através dele, o tempo; mas como todas as leituras, a "intencionalidade" ou a inerente pré-fornecida "interpretação" do tempo já é seletiva. Primeiro, observe que a representação do tempo em um relógio bem como face à sua percepção espacial é temporal. Se fosse possível simplesmente reduzir o movimento temporal como uma característica perceptível em relógios, o já notado estranho ou irregular movimento do tempo poderia muito 
bem ser selecionado. Mas tempo é sempre tempo-espaço, então num sentido mais fundamental a quase espacialidade da representação do tempo não é em si algo como uma distorção total. Quando isto é levado em conta, pode-se perceber que relógios tradicionais representam duas dimensões de tempo - simultaneamente e visualmente.

Uma dimensão é o instante do tempo. Esta é a representação localizada analogicamente na posição precisa das mãos. Em relógios de ponteiro único, aquele instante em si poderia ser considerado algo "amplo" no que a mão poderia ser posicionada em algum clique, sobre ou entre as horas. A outra dimensão é o "vão" ou duração do tempo, que é representado pela face do relógio, seja circular (tal como em algum relógio de água muito antigo) ou seja um círculo parcial ou arco (como nos relógios solares).

Além disso, o instante do tempo em que o ponteiro se encontra é localizado junto ou sobre o campo da representação de duração do tempo. Essas duas dimensões permanecem constantes na evolução dos relógios até recentemente. No entanto, houve refinamentos na evolução dos relógios que apontam para uma trajetória particular. Essa trajetória segue precisamente aquelas tendências já notadas igualmente por Mumford e Heidegger.

Relógios de ponteiro único, que fazem a discriminação entre horas, foram substituídos logo cedo por relógios com dois ponteiros, que depois dividiam ou quantificam o tempo em minutos. Duas coisas aconteceram com este refinamento da medição: não apenas o tempo foi mais finamente quantificado em unidades menores, mas num senso muito sutil, pode-se dizer que os minutos gradualmente se tornaram mais "importantes" do que as mais amplas unidades hora. A trajetória se dá rumo ao instante, fazendo-o mais focal e consequentemente colocando a duração do tempo mais para o segundo pano.

Se se deseja saber "exatamente" que horas são, olha-se para o ponteiro da hora e simultaneamente para o campo do ponteiro do minuto. Pode-se ver num relance, na forma visual familiar, que são dez para as doze. Depois, ainda, um terceiro ponteiro foi adicionado, e uma forma mais avançada de precisão do instante se tornou possível, o segundo. Eu não preciso destacar a importância desta gradual precisão do instante para a práxis da ciência e para a arte das medições, além de indicar que isto é também outra exemplificação da ciência tecnológica tal como ela emerge historicamente.

A trajetória rumo à primazia do instante pode também ser ilustrada em termos do tempo público. A análise do tempo da Revolução Industrial, no qual 
estudos sobre o movimento-tempo se tornaram os próprios exemplares da medição, e tempo digital ou atomizado na práxis da fábrica enfatizaram acerca da percepção e uso do tempo. Pode-se notar uma experiência ainda mais ordinária. Quanto dura o quociente de ansiedade se compará-lo no espaço das culturas com e sem relógio? Tome como exemplo o simples encontro marcado para um almoço. O habitante da cultura sem-relógio talvez concordasse em encontrar o outro "sob a árvore do Baobá quando o sol estivesse alto no céu." O primeiro a chegar não vivenciaria o esperar como uma ansiedade ou se afligiria por um longo período, por horas em alguns casos, porque a sensação do tempo aqui não é apenas focada no instante, mas porque toda a concepção do tempo cultural se perdeu. Contrariamente, o homem de negócios na Trade Tower começará a ficar ansioso em questão de minutos, certamente em muito menos que meia hora, se o seu cliente se atrasar.

O término desta trajetória é alcançado com a introdução do relógio digital ordinário. Agora o instante e com ele a irregularidade do salto de um número para outro foram tão enfatizados que a representação do campo ou da duração do tempo desaparecem totalmente. Logo foi reconhecido que tal dispositivo não se tratou apenas de uma magnificação de alguma dimensão do tempo, mas a eliminação virtual e o deslocamento ou a redução total perceptiva na representação do tempo. Ao rejeitar esta perda, as pessoas optam novamente por modelos de relógios que são tanto digitais quanto analógicos. De passagem, pode-se notar também que o processo de leitura em si muda. Um relógio analógico encaixa-se na forma da percepção visual, pois é lido num relance em que igualmente o instante e o campo são simultaneamente dados. O relógio digital representa apenas o instante, e assim a duração precisa ser inferida, demandando, dessa forma, um diferente processo mental.

As culturas que fazem uso do relógio leem o tempo através do relógio. A percepção do tempo é mediada, percepção hermenêutica. Nós observamos que para a Europa Ocidental esse tempo práxis já foi sedimentado antes da Renascença e do surgimento da ciência moderna. E este é o maior fator das diferenças culturais, particularmente aquele que contrasta com as culturas do relógio solar.

\section{B. Técnicas do Mundo da Vida: percepção do espaço}

Se a ciência de Galileu poderia pressupor o contexto da cultura do relógio em suas sutis transformações no que diz respeito ao tempo, então ela poderia 
assumir uma percepção do espaço tecnologicamente mediada e matematicamente interpretada. Mais uma vez eu sugiro que Galileu foi, de fato, quem apontou tardiamente certas consequências para uma já estabelecida práxis de mundo da vida, embora isto de forma alguma lance dúvidas sobre sua genialidade científica.

O exemplo da percepção espacial aqui é encontrado nas navegações de longa distância. Pelos padrões mundiais, europeus eram navegadores transoceânicos retardatários. Navegadores do Pacífico Sul de fato se espalharam pelo Pacífico um milênio antes mesmo de Leif Ericson; os chineses foram os senhores do comércio do Pacífico Norte e dos oceanos indianos; e os árabes cobriram os oceanos séculos antes de Cristóvão Colombo descobrir o Novo Mundo. Também de maneira precedente às viagens que viriam a preencher nossas histórias, existem evidências de longas viagens acidentais, tais como aquelas nas quais esquimós encalharam na Irlanda em tempos medievais e destroços de galeões romanos recentemente foram encontrados na costa brasileira. Também é provável que muitas migrações pré-históricas aconteceram via barcos. As viagens transoceânicas da Europa moderna se deram relativamente tarde.

Estimulados pela fome por bens que viriam a alimentar o apetite dos europeus desde as Cruzadas, os primeiros navegadores praticaram navegação costeira durante séculos antes de Colombo. Mas navegação costeira é amplamente uma operação feita a "olho". Os navios não precisam se distanciar muito da costa; eles podem ancorar ou aportar em tempo adverso; e eles podem fazer assim uma viagem prazerosa e relativamente segura. Isto não é dizer que técnicas às cegas para certas travessias não existiam; elas podem ser encontradas já nos tempos dos fenícios, gregos e romanos. Mas a navegação transoceânica de longa duração apresenta muito mais problemas difíceis de orientação espacial.

Excluindo-se as lendas, tal viagem primeiramente documentada foi a de Leif Ericson e de seus parentes, os vikings, que descobriram a Groelândia e a Terra Nova e ali desenvolveram suas colônias. Infelizmente, pouco se sabe de tais métodos de navegação utilizados, mas existem algumas dicas de que tão cedo quanto estas viagens uma forma primitiva de mediação tecnológica pode ter sido empregada.

Polaris, a Estrela do Norte, era, sem dúvida, familiar. Para os navegadores do Hemisfério Norte, esta estrela fixa fornecia uma constante não disponível para o Hemisfério Sul. Um segundo fenômeno fortuito é o Polo Norte magnético, que, grosso modo, corresponde à posição espacial de Polaris. Tais pontos fixos podem ser muito úteis para orientação espacial e foram assim usados em 
tempos antigos. Existem dicas de que os vikings podem ter tido um ímã primitivo. Ele pode ter sido um dispositivo de mediação tecnológica. (Os chineses definitivamente tiveram a bússola e fizeram dela central para muito de suas técnicas de navegação.) Tal dispositivo, tal como o relógio, permitia certo distanciamento do fenômeno imediato natural. Por exemplo, num nevoeiro, nem o Sul ou Polaris poderiam ser vistos, e o ímã poderia, assim, prover uma constante pela qual podia se direcionar.

É remotamente possível que os vikings tiveram um dispositivo anteriormente desconhecido por nós, a pedra azul. Os navios vikings têm sido frequentemente descobertos e dentro da desordem encontrada no interior dos cascos estão várias pedras. Grandes pedras deveriam ser, sem dúvida, o lastro. Mas em meio a estas pedras grandes encontram-se um número de pedras planas, em formato de disco, estriadas com linhas paralelas de quartzo ou algum outro mineral. Tem sido sugerido que tais pedras foram usadas na neblina ou em nevoeiros leves para localizar a posição solar da qual eles refletiam efeitos visíveis, mesmo quando o sol não podia ser visto. Um conhecido meu, piloto da Scandinavian Airline System (SAS), afirma ter usado tais pedras azuis para tal propósito e confirma que elas de fato funcionam. Tais auxílios para a navegação poderiam sugerir que os vikings já haviam seguido o que se tornaria a trajetória dominante europeia da navegação tecnologicamente mediada.

Se tomarmos Colombo como nosso exemplo, contudo, esta conclusão é evidente, e é paralela à transformação da percepção do tempo com o relógio, a navegação transoceânica europeia foi para eles igualmente tecnológica e matematicamente mediada. Ele usou cartas de navegação divididas em meridianos similares aos que são usados atualmente. Do século XIII em diante, Portulanos, que eram cartas náuticas das costas demarcadas pelos padrões dos ventos dominantes, já eram familiares. Aqui a perspectiva do voo de pássaro já estava estabelecida, uma prática que contém implicações sutis, mas profundas para a orientação espacial. E Colombo calculou sua latitude por meio de indicações astronômicas e aferiu seu posicionamento em conformidade a isto (medições longitudinais surgiram séculos depois até que relógios marítimos de alta precisão surgiram para mediar estas medições). Este cálculo foi auxiliado por instrumentos como, ao menos, um simples astrolábio. Outros instrumentos de medição também eram comuns, tal como a barquinha ou barca, uma corda com uma prancha na ponta, na qual eram feitos nós para se medir a velocidade. Quando lançada ao mar, a velocidade do navio podia ser calculada com base 
numa medição em uma ampulheta, de acordo com quantos nós eram contados num determinado tempo. "Nós" e "barca" tornaram-se termos da navegação a partir deste dispositivo.

Em suma, Colombo empregou, com base numa práxis familiar, uma série de instrumentos para calcular simplesmente em termos matemáticos a posição onde ele se encontrava. A peculiaridade desta práxis não será evidente até que variações contrárias aos modos de navegação fossem estabelecidas; mas no contexto imediato, basta notar que a forma tecnologicamente mediada da percepção espacial já era familiar um século antes de Galileu e, portanto, era parte do mundo da vida cotidiana, pelo menos, para os navegadores da época.

As tensões sobre o quão distante o Oriente deveria estar vieram à tona não tanto porque indivíduos temiam cair fora dos limites do mundo (todas as pessoas educadas sabiam que a terra era redonda), mas porque o tamanho da terra era seriamente subestimado. Essa crença na pequeneza não foi corrigida durante alguns séculos, mas a crença pode estar relacionada com as prévias subestimações acerca do tamanho dos céus feitas já mesmo antes dos gregos. Eu suspeito que o escorço que pertence à micropercepção desempenhe algum papel neste fenômeno de crença.

Para dizer se Colombo já era "tecnológico" em sua ciência de navegação, ainda resta detectar alguns aspectos sutis do mundo da vida das percepções que pertencem a sua práxis. E há um aspecto muito peculiar que pode ser encontrado nas práxis navegacionais europeias (e depois de todo o Ocidente) no que diz respeito ao da qual, ou posição a partir da qual a localização é determinada. Eu me refiro ao que pode ser chamado de posição do voo do pássaro. Colombo não declara estar posicionado simplesmente "aqui” (a bordo, encarnado, localizado junto às percepções circundantes imediatas). Antes disso, ele "lê" a si mesmo como estando em alguma posição sobre um mapa como se ele estivesse de alguma forma acima do navio no qual estava viajando e julga esta posição a partir de uma perspectiva imaginativa ou desencarnada (disembodied) que, de fato, ele não ocupa.

Eu descrevi o caso deliberadamente dessa forma, porque a premissa da perspectiva do voo do pássaro é tão familiar para nós que automaticamente acompanhamos suas peculiaridades como sendo uma segunda natureza práxica. A situação pode ser mais cuidadosamente analisada se atentarmos para a fenomenologia da leitura de mapas. 
Um mapa ou carta de navegação é literalmente lido de cima. Enquanto ele representa o terreno, tal terreno é visto a partir dos céus. É o mesmo que "ver" a terra a partir de uma posição que eu de fato não ocupo. E porque isto é assim, para fazer a leitura intuitiva de mapas, para constituir a intuição, eu preciso aprender a fazer um salto hermenêutico. Imagine nosso Colombo com um mapa sobre águas desconhecidas (Figura 3).

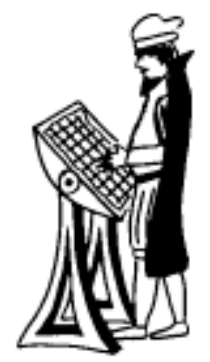

Ele conhece, a partir de experiências anteriores e pela cartografia vigente, os aspectos costais da Europa. Ele navega para o Oeste ao longo de uma latitude de aproximadamente um paralelo, traçando o seu progresso com distâncias estimadas. Mas ele continua a localizar a si mesmo neste gráfico, do alto. Agora, esta é, efetivamente, sua posição de leitura e, nessa medida, a micropercepção é encarnada, mas esta não é sua posição de fato no que diz respeito ao ambiente imediato do oceano. Para estabelecer isso, precisamos correlacionar a posição do voo do pássaro com uma segunda posição encarnada; e isso demanda um ato hermenêutico específico.

A questão pode ser clarificada através de uma série de possíveis variações cartográficas. Mapas precisam não ser elaborados a partir da perspectiva do voo do pássaro. Alguns mapas são simplesmente leituras de direções: "Para alcançar minha casa a partir da universidade, tome a saída do fundo da nossa universidade, vire à esquerda para a Nicolls Road até alcançar o semáforo, então vire à direita para a 25A." Aqui, uma instrução escrita funciona como um mapa. Ou um mapa pode ser desenhado para representar, como se fosse uma foto, uma série de representações perceptivas que podem ser isomórficas no que diz respeito à posição do motorista e da paisagem circundante. Neste caso, eu posso ter instruído o motorista para olhar em sequência para um conjunto de fotos que deu a ele mostrando primeiro a partir da posição do motorista a saída da universidade, depois o semáforo na intersecção, etc. Tal série pode, de maneira 
isomórfica, representar o que pode ser visto a partir do assento do motorista em tal-e-tal estágio da viagem.

Nossos mapas usuais, no entanto, fazem algo mais. Eles estabelecem posições ao requerer uma percepção hermenêutica, e a posição do mapa pode ser "lida" junto a nossa posição perceptiva corpórea. A dificuldade que isto acarreta é óbvia para qualquer um que tenha navegado longe da costa, particularmente em condições obscuras e num território não familiar. O que o mapa revela é retratado a partir do alto - e então se pode traduzir que esta marcação aqui no mapa deve ser aquela torre ali na costa (?). Mesmo que fosse para se ler o mapa a partir da posição de um avião voando à baixa altitude, deveria ainda assim haver mais que um modelo de isomorfismo, mesmo que nós façamos tais atos hermenêuticos em contexto bastante ordinários. O próprio processo de leitura tornou-se uma aquisição de nosso mundo da vida que faz com que um aspecto de nossa própria noção de perspectiva seja habitual.

No caso de Colombo, esta breve descrição deve ser suficiente para demonstrar que a localização já estava geometricamente estabelecida; e que o estabelecimento de tais localizações demandam percepções hermenêuticas; e que junto a este contexto hermenêutico, a instrumentalização é usada para mediar as percepções. Este é o paralelo prático para as técnicas da Renascença no que diz respeito à perspectiva e à geometrização. Colombo e da Vinci foram, afinal, contemporâneos. Esta práxis já era comum um século antes de Galileu utilizá-la em um novo contexto. Ela era parte do mundo da vida que ele pode assumir e tomar como certo.

\section{Artefatos e tecnofatos}

Nossas ações são incorporadas nas múltiplas formas em que interagimos com nossas tecnologias e as pressupomos, ainda que esta multiplicidade permaneça perceptiva e praxiologicamente ambígua. O que existe sobre os artefatos que empregamos? A junção humano-tecnologia apresenta uma ambiguidade enigmática. Imagine que existe, sobre minha mesa de centro, uma pedra em forma simétrica. Ela é de forma ovalada com uma das pontas mais afiada que a outra, achatada por ter sido lascada, de forma que uma marca afiada corre por toda a circunferência. Meus convidados chegam; e depois da primeira rodada de drinques, alguém pega a pedra e pergunta: "O que é isto?" 
O artista que está na festa toma a pedra e pronuncia que ela é um objet toruvé (um objeto escolhido aleatoriamente considerado esteticamente agradável). É uma espécie de objeto artístico. O escritor, que nota que a brisa está agora agitando as páginas da revista sobre a qual a pedra estava colada, rebate dizendo que a pedra é meramente um contrapeso para papel, um objeto prático. Mas o antropólogo zomba deles, e com deduções como as de um detetive afirma que ela é, na realidade, um machado de mão acheuliano. Ele nota não apenas que o objeto é formatado apropriadamente, mas que objetos deste tipo são uma parte familiar ao conjunto de ferramentas da Idade da Pedra, encontrados desde as margens do Rio St. Acheul na França até o Rio Vaal na África do Sul.

A dificuldade latente a este questionamento é genuína. O que é o objeto? O objeto é ou pode ser qualquer das coisas denominadas, ou pode se tornar algo a partir da forma como for usado. Isto, também, é uma ambiguidade essencial às tecnologias. Sendo um objeto, o machado de mão acheuliano pertence a um variado número de contextos de uso; mas o antropólogo replica: ele foi projetado para ser um machado de mão, e assim tem sido tomado por décadas pelos classificadores no campo.

Todavia, outro convidado informado menciona ter lido um artigo em uma recente edição da Revista de História Natural sobre este mesmo machado. Parece, depois de décadas de noções aceitas sobre o seu uso projetado que existe uma anomalia para o machado de mão, a circunferência afiada teria sido certamente perigosa para o usuário. E em uma pequena mudança de forma, o autor propôs que talvez o "machado" era de fato um projétil, que servia para ser lançado como um disco. Empregando uma boa prática científica contemporânea, o autor do artigo pediu para que arremessadores de discos profissionais lançassem o objeto e assim constatou que a parte pontuda e afiada tocou o chão primeiro em 31 de 45 arremessos! Uma nova interpretação sobre o uso projetado começa a tomar forma.

O que nós temos neste exemplo poderia ser reconhecido pela literatura humanista como sendo o correspondente antropo-arqueológico de uma falácia intencional. Em círculos literários, faz tempo, muito antes de deixar de ser moda, que se parou de procurar pelas "intenções" de um autor em uma estória escrita; de fato, tem sido argumentado que sequer é possível fazer isto. Neste caso, as intenções do designer são procuradas, mas permanecem em questão. De modo similar, em qualquer bom exercício interpretativo (hermenêutico), o humanista viria a reconhecer que enquanto existirem intenções, a estória pertence a um 
diferente contexto e é possível para múltiplos contextos. Então, do mesmo modo, acontece com a pedra. As intenções do designer desempenham apenas um pequeno papel para a subsequente história do artefato. Afinal, foi a intenção de Nobel, com a invenção da dinamite, que ela fosse usada para a mineração e em benefício da humanidade. Design, na história da tecnologia, usualmente ocupa uma posição secundária junto à multiplicidade de usos, poucos dos quais foram intencionais no momento de seu lançamento.

Até mesmo em um nível mais profundo, esta multiplicidade de usos revela uma pista fenomenológica inicial que precisa ser seguida. Não existe a "coisa-em-si”. Existem apenas coisas em contextos, e contextos são múltiplos. Pode-se facilmente voltar para o nosso ex-machado de mão e ir além, imaginando a pedra numa estória primal de caçadores da Idade da Pedra, escondendo-se junto aos juncos dos antigos rios, agora emergindo como um grupo da "artilharia” bombardeando ou apedrejando um rebanho de antílopes ou um bando de gansos. Agora podemos localizar a pedra em inumeráveis contextos. Eu poderia tê-la utilizado como uma pedra angular em alguma de minhas lareiras em Vermont; os meus vikings poderiam tê-la colocado no porão do navio, como um lastro; ou alguém poderia tê-la cimentado, com a ponta para cima, ao longo do topo das cercas de pedra, tal como os europeus faziam.

A ambiguidade dos objetos acheulianos é a ambiguidade da tecnologia em geral. Existe outra razão por não começar com um objeto como sendo objeto. Um objeto tecnológico, qualquer que ele seja, torna-se o que ele "é" por meio de seus usos. Isto não dizer que as propriedades técnicas dos objetos são irrelevantes, mas é dizer que tais propriedades em uso tornam-se parte da relatividade humano-tecnologia. E nem isto é negar que existe um tipo específico da história para o desenvolvimento das propriedades técnicas.

Técnicas animais são frequentemente o uso temporário de simples objetos encontrados (espinhos, gravetos, etc.) e este é, sem dúvida, o caso dos primeiros humanos. Mas gravetos não permanecem gravetos. Eles se tornam lanças, e neste processo há uma formatação e manufatura em artefatos tecnológicos. Os aborígenes australianos regularmente arrancavam as longas e retas hastes de certas plantas para suas lanças, mas em seguida eles prendiam pontas de madeira endurecida pelo fogo nas extremidades das lanças, usando colas e rejuntes vegetais. Eles começaram a transformar a qualidade simplesmente "encontrada" em tais objetos. 
Transformações mais complexas ou de alta ordem também começaram a ocorrer no passado, mas foram aceleradas nos contextos atuais de alta-tecnologia. O que eu chamarei de tecnofatos é um objeto no qual a matéria em si tenha sofrido níveis de transformação. Plásticos, agora onipresentes, simplesmente não ocorrem na natureza. (Embora substâncias similares possam ser aproximadas ao plástico. Eu lembro-me de ter visto pisos pretos e brilhantes nas tradicionais cabanas em forma de colmeia dos zulus, e notado o quanto estes materiais se pareciam com o plástico. Quando eu perguntei como eles eram feitos, a resposta foi "formigueiro e esterco de vaca.")

Uma vez que a trajetória tecnológica tenha começado, artefatos e tecnofatos se tornaram gradativamente diferenciáveis dos produtos naturais. Mas isto também é um sinal da entrada na relatividade humano-tecnologia. Mesmo as propriedades técnicas adquirem uma significância no contexto do uso. Pedra, uma vez formatada, adentra na práxis. A dureza se torna dureza para ponta afiada, ponta afiada para . Assim o que é "natural" na pedra se torna artifactual junto à relatividade.

Se a ambiguidade do objeto é um lado do problema, então o outro lado é que virtualmente qualquer objeto pode se tornar finalmente uma tecnologia, se puder ser trazido junto à variedade da práxis humana. E se nosso machado de mão pode ter sido ou pode ter se tornado um objeto em uso em uma variedade de contextos, o inverso também é o caso. Qualquer contexto de uso também pode utilizar qualquer número de artefatos ou tecnofatos. Se o martelo de Heidegger pode ser usado como um martelo (seu propósito projetado), mas também como a arma de um assassino, um objeto de arte, um contrapeso, etc., então qualquer número de itens pode ser usado para martelar, incluindo o machado de mão acheuliano.

Esta ambiguidade de objetos em contextos de uso é abundantemente ilustrada nas histórias de transferências tecnológicas. A roda de oração hindu (um moinho de vento que é uma máquina de oração autômata, que faz com que a oração vá para os céus toda vez que o vento gira a roda), de Lynn White, tornou-se uma fonte de energia para drenar as terras baixas holandesas. Os conquistadores espanhóis bastante cientes usaram sinos de aves (pequenos sinos de bronze utilizados na falcoaria) e espelhos, ambos projetados para diferentes propósitos, como bugigangas para o comércio e a fascinação dos indígenas da América Central e do Caribe. Quando o objeto é transferido, seu uso pode ser bem diferente daquele de seu contexto cultural prévio. 
Todas estas ambiguidades podem ser notadas antes de uma fenomenologia mais rigorosa das relações humano-tecnologia. O propósito de tal fenomenologia, no entanto, é reduzir a abertura notada junto à ambiguidade para uma análise estrutural que atravessa e representa a variedade de possibilidades que ocorrem dentro da ambiguidade essencial da tecnologia. 


\section{5 \\ Programa Um: A Fenomenologia DA TÉCNICA}

A tarefa da fenomenologia das relações humano-tecnologia é descobrir os vários aspectos estruturais daquelas relações ambíguas. Para realizar esta tarefa, devo começar com o foco sobre os aspectos experimentalmente reconhecíveis que estão centrados sobre os modos como somos corporalmente engajados com as tecnologias. O começo será junto aos vários modos nos quais "eu-enquanto-corpo" interajo com meu ambiente por meio das tecnologias.

\section{A. Técnicas incorporadas}

Muito da ciência moderna obteve sua nova visão de mundo por meio das tecnologias óticas, e o processo de incorporação é igualmente muito antigo e mais difuso. A incorporação da práxis através das tecnologias é em última instância uma relação existencial com o mundo. É algo que os humanos possuem sempre, desde que deixaram as percepções nuas como as do Jardim.

Anteriormente, de uma maneira mais sugestiva, já apontei alguns aspectos da incorporação visual das tecnologias óticas. A visão é tecnologicamente transformada através de tais óticas. Mas enquanto o fato de que a ótica transforma a visão possa estar claro, as variáveis e invariáveis de tal transformação ainda não estão precisas. Esta se torna a tarefa para uma fenomenologia estrutural mais 
rigorosa da incorporação. Eu devo iniciar por descrever a partir de alguns aspectos anteriormente mencionados na fenomenologia preliminar das técnicas visuais.

Junto à estrutura da relatividade fenomenológica, as técnicas visuais precisam primeiramente ser localizadas junto à intencionalidade do ato de ver.

Eu vejo - através dos artefatos óticos - o mundo

Este ato de ver é, em qualquer variação, ao menos minimamente distinto de uma visão direta ou nua.

\section{Eu vejo - o mundo}

Eu chamo este primeiro conjunto de relações existenciais tecnológicas junto ao mundo de relações de incorporação, porque neste contexto de uso eu tenho as tecnologias dentro da minha experiência de um modo particular pela via de perceber através de tais tecnologias e por meio da transformação reflexiva da minha percepção e dos meus sentidos físicos.

No uso que Galileu faz do telescópio, ele incorpora sua visão através do telescópio. Assim:

\section{Galileu-telescópio-Lua}

De forma equivalente, o uso de óculos incorpora a tecnologia dos óculos:

Eu-óculos-mundo

A tecnologia está de fato entre o observador e o observado, numa posição de mediação. Mas o referencial da visão, ao qual a vista é direcionada, é "por outro lado" a ótica. Enxerga-se através da ótica. Isto, no entanto, não é o suficiente para especificar esta relação como sendo um tipo de incorporação. Isto porque é preciso primeiramente determinar onde e como, junto ao que será descrito como sendo um continuum de relações, a tecnologia é vivenciada.

Existe um sentido inicial no qual este posicionamento é duplamente ambíguo. Primeiro, a tecnologia precisa ser tecnicamente capaz de se deixar ver através dela; precisa ser transparente. Usarei o termo técnico para me referir às características físicas da tecnologia. Tais características por ser designadas ou elas podem ser descobertas. Aqui as disciplinas que tratam de tais características são informativas, embora indiretamente, para a análise filosófica per se. Se 
o vidro não é suficientemente transparente, ver através não é possível. Se ele é suficientemente transparente, próximo ao que quer que seja "puro" para que a transparência possa ser empiricamente alcançável, então se torna possível incorporar tal tecnologia. Esta é a condição material para a incorporação.

Incorporar, enquanto é uma atividade, também possui uma ambiguidade. Ela precisa ser aprendida ou, em termos fenomenológicos, constituída. Se a tecnologia é boa, isto normalmente é fácil. A primeira vez que coloquei meus óculos, vi então o mundo agora corrigido. Os ajustes que eu tive que fazer não eram tipicamente irritações focais, mas ajustes marginais (tal como o ajuste o reflexo e algumas pequenas alterações na motilidade espacial). Mas uma vez assimilados, a relação de incorporação pode ser mais bem descrita como uma na qual a tecnologia se torna maximamente "transparente". Isto é, tal como foi, levando em conta minha própria experiência de percepção corporal. Assim:

$$
\text { (eu-óculos)-mundo }
$$

Meus óculos tornaram-se parte do modo como eu ordinariamente vivencio meus arredores; eles "se retiram" e sequer são notados, afinal. Eu tenho então incorporado ativamente as técnicas da visão. Técnica é a simbiose do artefato e do usuário junto à ação humana.

As relações de incorporação, no entanto, não são todas restritas às relações visuais. Elas podem ocorrer em qualquer dimensão dos sentidos ou da micropercepção. Um aparelho de audição faz isto para a audição, e a bengala do cego pela mobilidade tátil. Observe que nestas tecnologias corretivas se obtém os mesmos aspectos estruturais da incorporação tal como no exemplo visual. Uma vez aprendidos, bengala ou aparelho de audição "se retiram" (se a tecnologia é boa e aqui nós temos uma pista experimental para o aperfeiçoamento das tecnologias). Eu ouço o mundo através do aparelho de audição e sinto-o (e ouço-o) através da bengala. A junção (eu-artefato)-mundo se dá através da tecnologia e é trazida para perto por ela.

Tais relações através das tecnologias não são limitadas seja para as tecnologias simples ou complexas. Vidros, ao passo que eles são sistemas projetados, são muito mais simples que aparelhos de audição. Mais complexos ainda que estes dois dispositivos monosensórios são aqueles que desempenham a motilidade do corpo-todo. Uma destas tecnologias comuns é a direção automotiva. Embora dirigir um automóvel compreenda mais que relações de incorporação, é prazeroso e frequentemente está associado com relações de incorporação. 
Vivencia-se a estrada e os arredores através da direção do carro, e o movimento é a atividade focal. Em carros esportivos sofisticados, por exemplo, pode-se ter um sentimento mais preciso da estrada e da tração sobre ela do que nos carros maiores e mais antigos dos anos 1950. Incorpora-se o carro também em atividades tal como o estacionamento paralelo: quando bem incorporado, sente-se em vez ver a distância entre os carros, e o sentido da carroceria é "ampliado" para os parâmetros do "corpo" do motorista. E embora estas relações de incorporação demandem maiores e mais complexos artefatos e empreguem de alguma forma um mais longo e complexo processo de aprendizagem, o aprendizado tátil sobre o corpo que se está a apreender é percepção-corporal.Aqui está a primeira pista para o sentido polimórfico da extensão corporal. A experiência de uma "imagem corporal" não é fixa, mas maleavelmente extensível e/ou reduzível em termos do material ou das mediações tecnológicas que possam ser incorporadas. Eu restringirei o termo incorporação, no entanto, àqueles tipos de mediação que podem ser assim vivenciadas. O mesmo polimorfismo dinâmico pode também ser localizado na experiência não mediada ou direta. Pessoas treinadas nas artes marciais, tal como o caratê, aprendem a sentir os vetores e trajetórias dos movimentos do oponente junto ao espaço de combate. O espaço próximo em torno de seu corpo material é modificado.

As relações de incorporação são um tipo particular de contexto de uso. Elas são tecnologicamente relativas em um duplo sentido. Primeiro, a tecnologia deve "enquadrar" o uso. De fato, junto ao reino das relações de incorporação pode-se desenvolver um conjunto bem específico de qualidades para o design no que concerne a obtenção do requisito tecnológico "se afastar". Por exemplo, ao manusear materiais altamente radioativos a distância, braços e mãos mecânicos que são desenvolvidos para pegar e derramar tubos de vidro no interior do compartimento blindado devem fornecer um "feedback" de um senso de toque delicado para o operador. O mais próximo da invisibilidade, transparência e extensão do próprio sentido de alguém que esta tecnologia possa proporcionar, melhor. Note que o design perfeito não é aquele relacionado à maquina em si, mas à combinação da máquina com o humano. A máquina é aperfeiçoada junto a um vetor corporal, moldado para as percepções e ações humanas.

E quando tais desenvolvimentos alcançam grande sucesso, eles podem fazer surgir certa romantização da tecnologia. Em muito da literatura antitecnologia existe um nostálgico chamado para uma volta às simples ferramentas tecnológicas. Em parte, isto pode ocorrer porque ferramentas de longo desenvolvimento 
são excelentes exemplos da expressividade corporal. Eles são igualmente diretos em termos acionais e imediatamente vivenciados, mas o que se perde é que tais relações incorporadas podem tomar qualquer direção. Igualmente o motorista do carro esportivo junto aos limites da pista de corrida e o motorista do trator de esteira destruindo uma floresta podem ter a satisfação das poderosas relações de incorporação.

Existe ainda um profundo desejo que pode surgir da experiência das relações de incorporação. É o desejo duplo de que, de um lado, há a vontade pela transparência total, incorporação total, para que a tecnologia verdadeiramente possa "se tornar eu". Se isso fosse possível, seria o equivalente a não ter nenhuma tecnologia, a transparência total seria meu próprio corpo e sentidos. Eu desejo o face a face que eu viria a vivenciar sem a tecnologia. Mas esta é apenas uma face do desejo. O outro lado é o desejo de ter poder, a transformação que a tecnologia torna disponível. Apenas ao usar a tecnologia é que o meu poder corporal é aprimorado e ampliado pela velocidade, através da distância ou por qualquer uma das outras formas nas quais a tecnologia muda minhas capacidades. Tais capacidades são sempre diferentes das minhas capacidades nuas. $\mathrm{O}$ desejo é, no mínimo, contraditório. Eu desejo a transformação que a tecnologia proporciona, mas eu a quero em certo sentido que eu possa basicamente não sentir sua presença. Eu a quero de uma forma que ela se torne eu. Tal desejo, da mesma forma que secretamente rejeita o que as tecnologias são, omite os efeitos transformadores que são necessariamente ligados às relações humanos-tecnologias. Este desejo ilusório equivale a ser a favor e contra as tecnologias nas interpretações sobre elas.

O desejo é igualmente a fonte dos sonhos utópicos e distópicos. A tecnologia atual ou material sempre carrega consigo apenas uma parcial ou quase transparência, com o seu preço para a extensão ou ampliação que as tecnologias proporcionam. Ao ampliar as capacidades corporais, a tecnologia também as transforma. Nesse sentido, todas as tecnologias em uso não são neutras. Elas mudam a situação básica, de maneira sutil, todavia minimamente; mas este é o outro lado do desejo. O desejo é simultaneamente um desejo para a mudança da situação para habitar a terra ou mesmo para ir além da terra enquanto algumas vezes inconsciente e secretamente desejando que este movimento possa ser sem a mediação tecnológica.

A direção do desejo aberto pelas incorporações tecnológicas também possuem seus golpes positivos e negativos. Instrumentalização nas atividades do 
saber, notavelmente na ciência, é a extensão gradual da percepção para novos reinos. O desejo é ver, mas enxergar é enxergar através da instrumentalização. Negativamente, o desejo pela pura transparência é o desejo de escapar das limitações da tecnologia material. É um platonismo que ressurge numa nova forma, o desejo de escapar da nova extensão corporal da união tecnológico. No desejo resta a contradição: o usuário igualmente deseja e não deseja a tecnologia. $\mathrm{O}$ usuário quer o que a tecnologia dá, mas não quer os limites, as transformações que um corpo tecnologicamente expandido implica. Há uma ambivalência fundamental diante da própria criação das nossas ferramentas terrestres.

A ambivalência que pode surgir a respeito das técnicas é a reflexão do tipo sobre a ambiguidade essencial que pertence às tecnologias em uso. Mas esta ambiguidade, eu argumentarei, possui sua própria forma distintiva. As relações de incorporação apresentam uma estrutura essencial de ampliação/redução que tem sido apontada nos exemplos sobre a instrumentalização. As relações de incorporação simultaneamente ampliam ou amplificam e reduzem ou colocam de lado o que é vivenciado através deles.

A visão das montanhas da lua, através de todo o poder transformacional do telescópio, retira a lua de seu conjunto na expansão dos céus. Mas se nossas tecnologias servirem apenas para replicar nossa experiência corpórea imediata, elas seriam de pouca valia e, por fim, de pouco interesse. Alguns exemplos absurdos podem ser apresentados aqui:

Numa anedota humorística, o professor irrompe para dentro de seu clube e anuncia que ele acaba de ter inventado uma máquina de leitura. A máquina faz escaneamento das páginas, as lê e então as reproduz perfeitamente. (A estória aparentemente foi escrita antes da invenção da fotocopiadora. Tais máquinas, pode-se dizer, são "máquinas de leitura perfeitas" de fato.) O problema, como o inocente pode notar, foi que esta máquina nos deixa precisamente com o problema que tínhamos antes de sua invenção. Ao serem reproduzidos através da "leitura" mecânica, todos os livros do mundo meramente apenas nos deixam na biblioteca.

A variante sobre a capa invisível do rei pode funcionar também. Imagina a invenção da roupa perfeitamente transparente através da qual nós podemos tecnologicamente vivenciar o mundo. Podemos ver através dela, respirar através dela, cheirar e ouvir através dela, tocar através dela. De fato, ela não produz nenhum efeito, apenas é perfeitamente invisível. Quem se proporia a usar tal roupa (mesmo se o presumível usuário pudesse encontrá-la)? Apenas ao perder alguma 
invisibilidade, ficando com uma coloração translúcida, é que essa peça passaria a ser vestível e mais interessante. Pois aqui, ao menos, a moda teria sido inventada, mas ao preço de perder a total transparência ao tornar-se aquilo através do qual nos relacionamos a um ambiente.

Tais estórias pertencem à imaginação extrapolada da ficção, que se coloca em contraste até as relações mínimas de incorporação atuais, que em suas dimensões materiais simultaneamente ampliam e reduzem, revelam e escondem.

Nas atuais relações humano-tecnologia do tipo de incorporação, as estruturas transformacionais podem também ser exemplificadas por variações: nas tecnologias óticas, eu já demonstrei como significações espaciais mudam em observações através da lente. Toda a formatação muda. Quando o aparente tamanho da lua muda, junto a ele a aparente posição do observador se transforma. Relativisticamente, a lua é trazida para "perto"; e de maneira equivalente, esta distância-proximidade ótica se aplica igualmente para a aparência da lua e meu senso de posicionamento corporal. Por exemplo, com mais e mais ampliação, o bem familiar fenômeno de profundidade, instrumentalmente mediado como sendo um "plano focal", também muda. A profundidade é reduzida em aproximações óticas.

Um fenômeno relacionado ao uso de um instrumento ótico é que ele transforma as significações espaciais da visão de uma maneira instrumentalmente focal. Mas minha visão sem a instrumentalização é uma visão totalmente corpórea, eu vejo não apenas com meus olhos, mas com todo o meu corpo em uma experiência sensorial unificada das coisas. Em parte, isto se dá porque há uma notável irrealidade para a aparente posição do observador, a qual apenas diminui com os hábitos adquiridos por meio da prática com o instrumento. Mas o instrumento ótico não pode transformar tão facilmente todo o panorama sensorial. O senso focal que é ampliado através do instrumento é unidimensional.

Aqui talvez seja a ocasião (embora eu não esteja sugerindo a causa) para certa interpretação dos sentidos. Historiadores da percepção têm observado que, nos tempos medievais, não apenas a visão não era o sentido supremo, mas som e cheiro podem ter tido papéis bastante reforçados na medida em que a interpretação dos sentidos prossegue. Ainda na Renascença e ainda mais exageradamente no Iluminismo, ocorreu uma redução à visão como sendo o sentido favorito, e junto à visão, certa redução da visão. Este favoritismo, no entanto, também carrega implicações para os outros sentidos. 
Uma destas implicações foi que cada um dos sentidos era interpretado como sendo claro e distinto dos outros, com apenas alguns aspectos podendo ser reconhecidos mediante tal sentido. Tal interpretação dificultou os primeiros estudos em eco localização.

Em 1799, Lazzaro Spallanzani fazia experimentos com morcegos. Ele notou não apenas que eles podiam localizar alvos de comidas no escuro, mas que eles também podiam fazer isto com os olhos vendados. Spallanzani perguntou-se se os morcegos poderiam guiar-se por seus ouvidos no lugar de seus olhos. Experimentos posteriores, nos quais os ouvidos dos morcegos eram tapados, demonstraram que de fato eles não poderiam guiar-se sem os ouvidos. Spallanzani supôs que ou os morcegos poderiam localizar objetos através da audição ou que eles possuem algum sentido sobre o qual os humanos nada sabiam. De acordo com a doutrina de separar sentidos e a identificação das formas e objetos apenas através da visão, George Montagu e Georges Cuvier virtualmente jogaram Spallanzani para fora da profissão.

Isto não é sugerir que tal interpretação da distinção sensorial ocorreu apenas devido simplesmente à familiaridade com as tecnologias óticas, mas a experiência comum da visão aprimorada por meio de tais tecnologias foi ao menos a prática padrão do tempo. Tecnologias auditivas estavam para chegar depois. Quando as tecnologias auditivas se tornaram comuns, foi possível detectar a mesma estrutura de ampliação/redução na experiência humano-tecnologia.

O telefone usado atualmente recai em uma relação de incorporação auditiva. Se a tecnologia é boa, eu ouço você através do telefone e o aparato "se retira" para a posição de fundo:

$$
\text { (eu-telefone)-você }
$$

Mas como um instrumento monossensório, sua presença fenomênica é a presença da voz. A presença ordinária multidimensional do encontro face a face não ocorre, e eu devo no máximo imaginar aquelas dimensões através das quais sua voz gesticula. Também, tal como o telescópio, as significações espaciais são modificadas. Há aqui uma versão auditiva da distância-proximidade visual. Faz pouca diferença se você está geograficamente perto ou longe, nem mesmo se você está ao norte ou ao sul, e nada diz respeito a nada, mas apenas a sua relação corporal para com o instrumento. Sua voz retém sua parcialmente irreal distância-proximidade, reduzida de toda dimensionalidade das situações perceptuais diretas. Esta distância telefônica é diferente tanto dos encontros imediatos 
face a face quanto da distância visual ou geográfica normalmente existente. Sua distância é a distância mediada com suas próprias significações identificáveis.

Enquanto meu conjunto de variações primárias está para ser localizado e demonstrar a invariância da estrutura de ampliação/redução para qualquer relação de incorporação, também existem efeitos secundários e importantes notados nas histórias da tecnologia. Na primeira vez que se fez uso do telefone, os usuários estavam fascinados e intrigados pela sua transparência auditiva. Watson ouviu e reconheceu a voz de Bell, mesmo que o instrumento imprimisse um alto nível de ruído à mensagem. Em suma, a fascinação ligada à ampliação, à amplificação e ao realce. Mas, contrariamente, pode existir um tipo de esquecimento que igualmente está ligado à redução. O que é revelado é o que excita; o que está oculto pode ser esquecido. Aqui se encontra um segredo para as trajetórias tecnológicas no que diz respeito ao seu desenvolvimento. Existem relíquias latentes que acontecem por meio das invenções.

Tais relíquias são evidentes o suficiente na história da ótica. A ampliação fornece o fascínio. Embora houvessem períodos de tempo com pouco progresso técnico, esta fascinação emerge de tempo em tempo ao ponto de chegar às lentes compostas nos dias de Galileu. Se alguma ampliação mostra o novo, abrindo para aquilo que anteriormente era detectado de maneira muito precária ou não detectado, o que uma ampliação maior pode fazer? Em nosso próprio tempo, a explosão de tais variantes sobre a ampliação é fascinante. Aprimoramento do elétron, melhoria da imagem computadorizada, escâneres internos CAT e NMR, telescópio "big-eye", a lista contemporânea da ampliação e dos instrumentos visuais é bastante longa.

Estou aqui me restringindo àquilo que pode ser denominado uma trajetória horizontal, isto é, tecnologias óticas que trazem vários micro ou macrofenômenos para a visão por meio das relações de incorporação. Ao restringir os exemplos a tais fenômenos, um aspecto estrutural das relações de incorporação pode ser apontado no que diz respeito à relação com a macropercepção e seu contexto adâmico. Enquanto o que pode ser visto mudou drasticamente, o Novo Mundo de Galileu foi agora ampliado pelo fenômeno astronômico nunca suspeitado e pelo microfenômeno ainda sendo descoberto e que permanece uma constante fenomenológica forte em como as coisas são vistas. Todas as lentes e tecnologias óticas do tipo sendo descritas forneceram o que está para ser visto junto ao espaço corporal e às distâncias normais. O macroscópico e o microscópico aparecem iguais junto à distância-proximidade. O "tamanho da imagem" 
de uma galáxia ou de uma ameba é o mesmo. Tal é a condição existencial para a visibilidade, o correspondente para condição técnica, que os instrumentos fazem as coisas visualmente presentes.

A presença mediada, no entanto, deve ajustar-se, ser aproximada para posição corporal e visão atuais. Assim existe uma referência junto ao contexto instrumental com minhas capacidades face a face. Isto permanece primitivo e central junto ao novo contexto de mediação. A teoria fenomenológica sustenta que para cada mudança naquilo que é visto (o objeto correlato), existe uma mudança perceptível em como (o correlato experimental) a coisa é vista.

Nas relações de incorporação, tais mudanças mantêm igualmente um equivalente e uma diferença das situações não mediadas. O que permanece constante é o foco corporal, a referência reflexiva volta para minhas capacidades corporais. O que é visto precisa ser visto a partir do meu campo visual ou junto dele, a partir da distância aparente na discriminação no que diz respeito à profundidade, etc., pode ocorrer, tal como nas relações face a face. Mas o conjunto do que pode ser trazido junto a esta proximidade é transformado por meio do instrumento.

Vamos imaginar por um momento o que nunca de fato foi um problema para a história da instrumentalização: Se o "tamanho da imagem" tanto da galáxia quanto da ameba é o "mesmo" para o observador usando o instrumento, como nós podemos dizer que um é macroscópico e outro é microscópico? A "distância" entre nós, humanos, e estas duas magnitudes eram, como Pascal notou, as mesmas que aquelas com as quais os humanos foram interpretados como estando entre o infinitamente grande e o infinitamente pequeno.

O que ocorre através da mediação não é um problema porque nossa construção da observação pressupõe a espacialidade de nossa práxica ordinária. Nós manuseamos o paramecium, colocando-o numa placa e então sob o microscópio. Nós apontamos o telescópio para o lugar indicado no céu e, antes de olhar através dele, notamos que a distância é, ao menos, aquela do domo cósmico. Mas em nosso experimento imaginário, o que seria se nosso humano estivesse totalmente imerso em um mundo tecnologicamente mediado? Aqui o problema pode se tornar mais difícil. Mas em nossa distância de Adão, é precisamente a presumida diferença que faz possível vermos igualmente a olho nu $e$ mediatamente e, assim, sermos capazes de localizar a diferença que nos posiciona ainda mais distantes de qualquer Jardim. É porque mantemos esta espacialidade ordinária que nós temos o ponto reflexivo de referência com o qual fazemos nossos juízos. 
A reflexividade noética ou corpórea implicada em toda visão também pode ser constatada de uma forma ampliada no período de aprendizagem da incorporação. O telescópio de Galileu tinha um campo pequeno, o qual, combinado com o fato de que era inicialmente empunhado, fez com que fosse muito difícil localizar qualquer fenômeno particular. O que deve ter sido notado, no entanto, mesmo se não houve comentários sobre isto, foi o exagerado senso de movimento corporal vivenciado por meio da tentativa de fixá-lo em um corpo celeste, e mais, pode-se aprender rapidamente algo sobre o próprio movimento da terra na tentativa de se usar tais telescópios primitivos. A despeito da aparente posição fixa das estrelas, o telescópio empunhado apresentava claramente o movimento da terra nos céus. Este efeito de ampliação se dá junto à experiência da própria visão corporal do observador.

Este ponto de referência corpóreo e ativo guarda certo privilégio. Toda experiência se refere a ele de uma maneira recuperável e tida como certa. A condição corporal da possibilidade para enxergar é agora duplamente indicada pela própria situação na qual a experiência mediada acontece. As relações de incorporação continuam a localizar tal privilégio do meu ser aqui. A simbiose parcial que ocorre nas tecnologias incorporadas bem projetadas guarda aquela mobilidade que pode ser chamada de expressiva. As relações de incorporação constituem uma forma existencial de todo o conjunto do campo do humano-tecnologia.

\section{B. Técnicas hermenêuticas}

O martelo de Heidegger em uso apresenta uma relação de incorporação. Ocorre por meio dele uma ação corporal junto ao ambiente. Mas quebrado, perdido ou em mau funcionamento, ele cessa de ser o meio da práxis e se torna objeto obstrutor para o projeto do trabalho. Infelizmente, esta derivação negativa da objetivação de Heidegger carrega junto consigo um bloqueio contra o entendimento de uma segunda relação existencial humano-tecnologia, o tipo de relação que eu denominarei hermenêutica.

O termo hermenêutica tem uma longa história. Em seu sentido mais amplo e mais simples, significa "interpretação", mas num sentido mais específico refere-se à interpretação textual e, assim, acarreta leitura. Eu manterei ambos os sentidos e tomarei a hermenêutica para significar uma ação interpretativa especial junto ao contexto tecnológico. Este tipo de atividade demanda modos especiais de ação e percepção, modos análogos ao processo de leitura. 
Ler é, certamente, a leitura de ; e em seu contexto ordinário, o que preenche o intencional branco é o texto, algo escrito. Mas toda escrita emprega tecnologias. Escrita é um produto. Historicamente, e mais antiga que a revolução provocada por tecnologias cruciais como o relógio e a bússola, a invenção e o desenvolvimento da escrita foram, certamente, ainda mais revolucionários que o relógio ou a bússola no que diz respeito à experiência humana. Escrever transformou a própria percepção e o entendimento que temos da linguagem. Escrever é a forma da linguagem tecnologicamente incorporada.

Atualmente há um debate em moda sobre a relação entre a fala e a escrita, particularmente na filosofia continental. Um lado argumenta que a fala é primária, tanto historicamente quanto ontologicamente, e outro, a Escola Francesa, inverte esta relação e afirma em favor da primazia da escrita. Eu não preciso aqui entrar neste debate a fim de observar a diferença tecnológica que existe entre o discurso oral e o processo materialmente conectado da escrita, ao menos em suas formas mais antigas.

A escrita é inscrição e apela para um processo de escrever em si, empregando um amplo conjunto de tecnologias (desde o estilo para a escrita cuneiforme até os processadores de palavras para a academia contemporânea), e outras entidades materiais sobre as quais a escrita é gravada (desde as placas de argila à impressão computadorizada). A escrita é a linguagem tecnologicamente mediada. Com base nisso, muitos aspectos das técnicas hermenêuticas podem ser destacados. Eu tomarei o que pode parecer à primeira vista um desvio para o âmbito de um conjunto das relações humano-tecnologia pela via de uma fenomenologia da leitura e escrita.

$\mathrm{O}$ ato de ler é uma atividade perceptiva especializada e práxis. Ele implica meu corpo, mas em certos modos distintivos. Num ato ordinário de leitura, particularmente do tipo longo, o que é lido é colocado diante ou de alguma forma sobre os olhos do leitor. Nós lemos num contexto imediato a partir de alguma forma miniaturizada da perspectiva do voo do pássaro. O que é lido ocupa uma extensão junto ao centro focal da visão, e eu estou ordinariamente em alguma forma de posição confortável. Se o objeto correlato, o "texto" no sentido mais amplo, é um mapa, como nos exemplos da navegação, o que é representado guarda um isomorfismo representacional com os aspectos naturais da paisagem. $\mathrm{O}$ mapa representa o terr(ou mar)eno e assim tal como os aspectos são isomórficos, há um tipo de "transparência" representacional. O mapa de um modo peculiar "refere-se" para além de si mesmo ao que é representado. 
Agora, no que diz respeito às relações de incorporação previamente descritas, tal representação isomórfica é igualmente similar e dissimilar ao que deveria ser, em uma larga escala, da posição de observação (ao nível do voo do pássaro). Isso é similar quando as formas no mapa são representações reduzidas ou aspectos distintivos que podem ser diretamente ou tecnologicamente mediados nas percepções incorporados ou face a face. O leitor pode comparar essas similaridades. Mas a leitura de mapas é também diferente no que, durante o ato da leitura, o foco perceptivo é o mapa em si, um substituto para a paisagem.

Eu usei deliberadamente o exemplo da leitura de mapa por vários propósitos. Primeiro, o isomorfismo "textual" da representação possibilita a este primeiro exemplo das técnicas hermenêuticas continuar próximas, ainda que diferenciadas, do isomorfismo perceptual que ocorre nos exemplos óticos. A diferença é ao menos perceptual no que se enxerga através da tecnologia ótica, mas agora se enxerga o mapa como fim visual, o artefato "textual" em si.

Algo muito mais profundo acontece, no entanto, quando o isomorfismo representacional desaparece em um texto impresso. Não há isomorfismo entre a palavra pintada e o que ela "representa", embora exista algum tipo de "transparência" referencial que pertence a esta nova forma tecnologicamente incorporada de linguagem. É aparente a partir do exemplo do mapa que o mapa em si se torna o objeto da percepção enquanto simultaneamente se refere em si mesmo àquilo que não é imediatamente visto. No caso do texto impresso, no entanto, a transparência referencial é distintamente diferente das percepções tecnologicamente incorporadas. Transparência textual é transparência hermenêutica, não transparência perceptual.

Historicamente, a transparência textual não era nem imediata e facilmente obtida. A "tecnologia" da escrita fonética, que agora é cada vez o padrão universal, se tornou o que é por meio de uma série de variantes e como um processo de experimentação. Uma forma antiga de escrita era a pictográfica. A escrita era ainda algo como o exemplo do mapa; a pictografia guardava certo isomorfismo representacional com o que era representado. Depois, uma escrita ideográfica mais complexa (tal como a chinesa) foi, com efeito, uma forma mais abstrata de pictográfica.

Calígrafos têm mostrado que mesmo a escrita fonética inicial seguia um processo gradual de formalização e abstração a partir de uma base pictográfica (Figura 4). Letras frequentemente representavam certo animal, a primeira sílaba de cujo nome fornecia o som para a letra num simultâneo som e letra. 
Configurada em tal fonética antiga a escrita foi assim algo como o modo que o alfabeto continua sendo ensinado para as crianças. "A de Abelha". Pessoas mais educadas têm familiaridade com a forma mista de escrita, hieroglífica. Embora a escrita seja pictográfica, nem todas as pictográficas continuam a mesma para a entidade descrita; algumas representam som (fonemas).

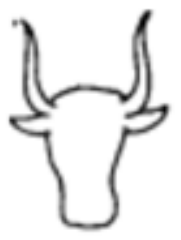

ApIs Egfipcio

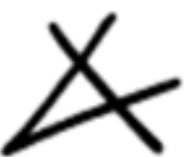

ALEPH Fenicio

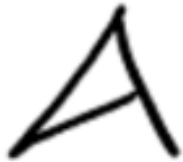

ALPHA

GREGO-

JONICO

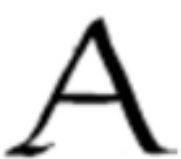

A

Um exemplo transcultural interessante deste movimento de uma estritamente pictográfica para uma formalizada e transformada ideografia escrita ocorre com a escrita chinesa. O mesmo movimento a partir das relativamente concretas representações nas pictografias ocorre por meio de abstrações abreviadas, mas em uma direção diferente, não fonética e ideográfica. Assim, para a escrita fonética há uma dupla abstração (da pictografia à letra e então reconstituindo um pequeno alfabeto finito em palavras faladas representadas), considerando que a duplicada abstração da escrita ideográfica não reconstitui as palavras como tal, mas em forma de conceitos.

$\mathrm{Na}$ escrita chinesa mais antiga no período da "Linguagem Casco da Tartaruga" (por volta de 2000 a.C.) e mesmo em alguns casos durante a posterior "Linguagem do Metal" (2000-500 a.C.), se alguém é familiar aos objetos tal como eles acontecem na cultura chinesa, ele pode facilmente detectar a representação pictográfica envolvida. Por exemplo, como se pode ver na Figura 5 que a ideográfica para barco de fato representa de maneira abstrata os barcos do tipo Sampan dos canais de rios (ainda em uso). De modo similar, na ideográfica para portão (Figura 6) pode-se ainda reconhecer o exclusivo portão tipicamente oriental no desenho. As variantes modernas relacionadas, mas mais abstratas têm claramente perdido aquele instante do isomorfismo representacional. 


\section{BARCO}

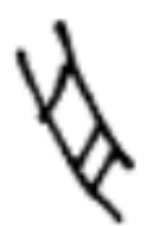

2000 A.C.

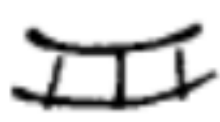

500 A.C.

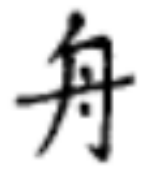

MODERNo

\section{PORTÃo}

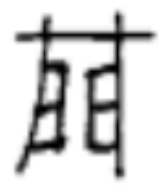

2000 A.C.

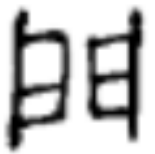

500 A.C

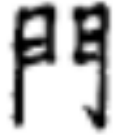

MODERNo

Implícitas a estas transformações estão as mudanças tanto da técnica quanto das tecnologias relacionadas. Sergei Eisentein, o cineasta sensível a tais tecnologias da imagem, apontou justamente para tais transformações que surgem a partir da invenção da tinta nanquim e pincel:

Mas então, ao final do terceiro século, o pincel é inventado. No primeiro século (a.C.) após o "feliz evento" o papel. E, finalmente, no ano 220 a tinta nanquim. Uma reviravolta completa. Uma revolução no desenho. E, depois de ter sofrido no curso da história não menos que quatorze diferentes mudanças no estilo de caligrafia, o hieróglifo cristalizado em sua presente forma. Os meios de produção (pincel e tinta nanquim) determinaram a forma. As quatorze reformas fizeram sua caminhada. E como resultado:
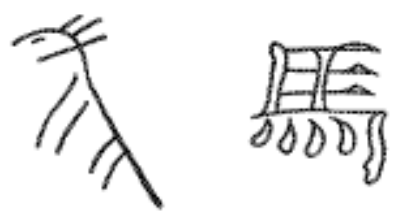

No hieróglifo do rampante em chamas ma (o cavalo) é impossível reconhecer os aspectos do querido cavalo pateticamente pouco robusto em seu traseiro no estilo de escrita de Ts’ang Chieh, tão bem conhecida a partir dos antigos bronzes chineses. ${ }^{1}$

1 EIRESTEIN, Sergei. Film Form: Essays in Film Theory, ed. and trans. Jay Leyda. New York: Harcour, Brace and World, 1949 , p. 29. 
Se este é um retrato acurado da evolução da escrita, ele segue parecido com a trajetória husserliana sobre a origem da geometria. A trajetória foi do mais concreto para os mais altos níveis de abstração, até que virtualmente toda "semelhança" às origens desaparecessem. Nesse sentido, a escrita apenas lentamente se aproximou da fala.

Uma vez obtida, como qualquer outra aquisição do mundo da vida, a escrita pode ser lida e compreendida em termos de sua transparência linguística única. A escrita tornou-se uma técnica hermenêutica incorporada. Agora as descrições podem tomar uma forma diferente. Aquilo a que se refere é referido pelo texto e refere-se a algo através do texto. O que agora se apresenta é o "mundo" do texto.

Isto não é negar que toda linguagem possui sua forma única de transparência. Referência para além de si mesma, a capacidade de deixar algo tornar-se presente por meio da linguagem, pertence também ao âmbito da fala. Mas aqui o fenômeno passa a ser centrado sobre a nova incorporação da linguagem na escrita. Ainda mais tematicamente, a preocupação é com os modos nos quais a escrita como uma "tecnologia" transforma as estruturas experimentais.

A transparência linguística é o que faz presente o mundo do texto. Assim, quando eu leio Platão, o "mundo" de Platão se faz presente. Mas esta presença é a presença hermenêutica. Ela não apenas ocorre através da leitura, mas toma sua forma no contexto interpretativo das minhas habilidades linguísticas. Seu mundo é linguisticamente mediado, e enquanto as palavras podem extrair todo tipo de fenômenos imaginativos e perceptuais, é por meio da linguagem que tal fenômeno ocorre. E enquanto tal fenômeno pode ser contundentemente rico, ele não se apresenta tal como o mundo.

Nós tomamos este fenômeno da leitura como certo. Trata-se de uma aquisição sedimentada no mundo da vida literário e assim segue despercebido até que a reflexão crítica isole seus aspectos salientes. O mesmo acontece com a ampla variedade de técnicas hermenêuticas que nós empregamos.

O movimento das relações incorporadas para as do tipo hermenêuticas pode ser muito gradual, tal como na história da escrita, com diferenciações sutis ao longo do continuum humano-tecnologia. As séries de variantes amplas sobre as tecnologias legíveis vão marcar o ponto. Primeiro, um exemplo francamente explícito de uma tecnologia de leitura: imagine-se sentado no interior em um dia frio. Você olha para fora pela janela e nota que a neve está soprando, mas você está bem aquecido em frente ao fogo. Você pode claramente "ver" o frio no fértil sentido da percepção de Merleau-Ponty, mas você de fato não o 
sente. É claro, você pode ir para o lado de fora. Você terá, então, uma verificação completa face a face do que tinha visto.

Mas você pode também ver o termômetro pregado na videira e ler que está $-2^{\circ} \mathrm{C}$. Você poderia "saber" agora o quão frio está, mas você ainda não o sentiria. Para manter o sentido pleno de uma relação de incorporação, algum isomorfismo também deve ser mantido junto à sensação de frio sentida, neste caso tátil, para se passar pela experiência face a face. Pode-se inventar tal tecnologia; por exemplo, algum material condutivo poderia ser colocado através da parede para que, assim, o "calor" negativo, que no caso é frio, pudesse ser sentido pela mão. Mas não é isto que o termômetro faz.

Em vez disso, você lê o termômetro e, no imediatismo da sua leitura, você sabe hermeneuticamente que está frio. Há uma instantaneidade para tal leitura, tal como já é uma intuição constituída (em termos fenomenológicos). Mas você não deve deixar de notar que perceptivamente o que você tem visto é o marcador e os números, o "texto" do termômetro. E este texto hermeneuticamente apresentou sua referência de "mundo", o frio. ${ }^{2}$

Tal imediação constituída nem sempre está disponível. Por exemplo, embora eu tenha frequentemente vivido em países onde centígrados substituem fahrenheit, ainda preciso traduzir de minha linguagem intuitiva familiar para uma menos familiar num ato hermenêutico autoconsciente deliberado. Imediatismo, no entanto, não é o teste para verificar se a relação é hermenêutica. A relação hermenêutica imita a percepção sensorial na medida em que também é uma espécie de vendo como ___ _ mas é uma visão referencial, que tem seu foco perceptual imediato vendo o termômetro.

Agora vamos deixar a situação mais complexa. No exemplo citado, o observador tem tanto a incorporação (vendo o frio) como o acesso hermenêutico ao fenômeno (lendo o termômetro). Suponha que a casa foi hermeticamente isolada, sem janelas, e o único acesso ao clima fosse por meio do termômetro (e qualquer outro instrumento que possamos incluir). O caráter hermenêutico da relação torna-se mais óbvio. Eu agora claramente tenho que saber como ler a instrumentação e a partir desta leitura ter conhecimento para apossar-me deste "mundo" ao qual se está referindo.

2 Esta ilustração é minha versão de uma versão similar elaborada por Patrick Heelan em sua noção mais totalmente hermeneutizada da percepção no HEELAN, Patrick. Space Perception and the Philosophy of Science, Berkeley: University of California Press, 1983, p. 193. 
Este exemplo tomou sua forma atual nas usinas nucleares. No incidente de Three Mile Island, o sistema de força nuclear era observado apenas através de instrumentação. Parte do atraso que quase causou a explosão foram equívocos na leitura dos instrumentos. Não havia face a face, nem acesso independente para o reator ou para muito da maquinaria envolvida, e nem poderia ter.

Uma análise intencional desta situação contém a posição de mediação da tecnologia:

eu-tecnologia-mundo

(engenheiro-instrumentos-reator)

O operador tem instrumentos entre ele ou ela e o reator nuclear. Mas aqui uma diferença essencial emerge entre as relações de incorporação e hermenêutica que é imediatamente percebida, é o painel do instrumento em si. Ele se torna o objeto da minha micropercepção, embora no sentido especial da transparência hermenêutica, leio o reator através dele. Esta situação demanda uma formalização diferente:

$$
\text { eu-(tecnologia-mundo) }
$$

Os parênteses agora indicam que o foco perceptual imediato da minha experiência é o painel de controle. Eu leio através dele, mas esta leitura é agora dependente de uma conexão semiopaca entre os instrumentos e o objeto referencial (o reator). Esta conexão pode agora tornar-se enigmática.

Nas relações de incorporação, o que possibilita a minha simbiose parcial com a tecnologia é a capacidade da tecnologia tornar-se perceptivamente transparente. Nos exemplos óticos, as artes de fabricação das lentes e vidros devem atingir este fim para que o uso incorporado se torne possível. Enigmas que podem ocorrer no que diz respeito ao uso incorporado transparente podem ocorrer desta forma junto ao parênteses das relações de incorporação:

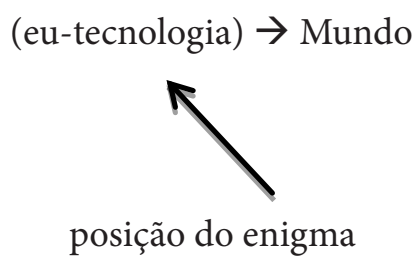


(Isto não é negar que, uma vez estabelecida a transparência, fazendo assim a micropercepção clara, o observador deva ainda falhar, particularmente ao nível macroperceptivo. Para o momento, no entanto, eu adiarei este tipo de problema interpretativo.) Seria uma simplificação demasiada da história de fabricação das lentes se problemas desta ordem não foram reconhecidos. Não apenas era difícil de olhar pelo instrumento de Galileu, mas ele era bom apenas para certo "alcance médio" de visão, em termos astronômicos (ele apresentou os planetas e no máximo alguns de seus satélites). Ao passo que os telescópios se tornaram mais potentes, níveis, problemas com efeitos cromáticos, efeitos de difração, etc., passaram a ocorrer. Tal como Ian Hacking apontou:

A ampliação é inútil se ela amplia dois pontos distintos em um grande borrão. É preciso esclarecer os pontos em duas imagens distintas. ... É uma questão de difração. O exemplo mais conhecido de difração é o fato de que as sombras de objetos com fronteiras nítidas são nebulosos. Esta é uma consequência do caráter ondulatório da luz. ${ }^{3}$

Muitos destes exemplos podem ser encontrados na histórica da ótica, problemas técnicos que tiveram que ser resolvidos antes que houvesse qualquer alcance extenso às relações de incorporação. De fato, muitas das barreiras para o desenvolvimento da ciência experimental podem ser encontradas em tais limitações na capacidade instrumental.

Aqui, no entanto, a tarefa é localizar a dificuldade paralela na nova relação emergente humano-tecnologia. A localização do problema técnico nas relações hermenêuticas repousa no conector entre o instrumento e o referencial. Perceptivamente, o terminus visual do usuário (ou outro) se dá sobre a instrumentalização em si. Ler um instrumento é algo análogo a ler o texto. Mas se o texto não se refere corretamente, seu objeto referencial ou seu mundo não podem estar presentes. Aqui é a nova localização para um enigma:

3 HACKING, Ian. Representing and Intervening. Cambridge: Cambridge University Press,1983, p. 195. Hacking desenvolve uma história excelente e sugestiva sobre o uso dos microscópios. Seu foco, no entanto, é sobre as propriedades técnicas que foram resolvidas antes que os microscópios pudessem ser úteis para as ciências. Heelan e ele, no entanto, com Robert Ackermann, estão entre os pioneiros que tratam da percepção e instrumentalização nos instrumentos. Cf. também o meu Technics and Praxis (Dordrecht: Reidel Publishers, 1979). 


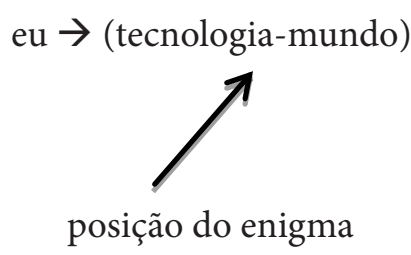

Enquanto o colapso pode acontecer em qualquer parte desta relação, a fim de trazer para fora a distinção graduada emergente entre incorporação e relações hermenêuticas, uma breve patologia dos conectores pode ser notada.

Se não houver nada que impeça minha condição de percepção direta em relação à instrumentalização (no exemplo de Three Mile Island, as luzes permaneceram acessas, etc.), problemas interpretativos ao ler um "texto" se comportando de maneira estranha ocorrem ao menos de início; mas o enigma técnico também pode ocorrer junto à relação texto-referencial. Como o operador pode dizer se o instrumento está com defeito ou é aquilo mesmo que o instrumento se refere? Alguma forma de opacidade pode ocorrer junto ao polo referencial-tecnológico da relação. Se houver alguma forma independente de verificar qual aspecto está apresentando defeito (o retorno às relações face a face sem mediação), tal pane pode ser facilmente detectada. Tais ocorrências são igualmente razões para a redundância instrumental. Mas nos exemplos em que tal verificação independente não é possível ou é inoportuna, a opacidade deverá continuar.

Vamos tomar uma simples conexão mecânica como caso incerto. Ao trocar as marchas do meu barco, há uma alavanca na cabine que, quando empurrada para frente, engata a marcha para frente; para cima, o neutro; e para trás, a ré. Por meio dela, eu posso sentir ordinariamente a mudança de marcha na transmissão (incorporação) e reconhecer a simples significação hermenêutica (para frente significa ir para frente) como sendo imediatamente intuitiva. Certa vez, no entanto, ao chegar às docas ao final da temporada, eu desengatei a marcha para frente, mas o propulsor continuou a dirigir o barco para frente. Eu rapidamente puxei para trás, mas o barco continuou. A significância hermenêutica havia falhado; e enquanto eu também sentia a diferença na forma como a alavanca de marchas se comportava, eu não descobri a não ser depois que o fecho que mantinha a alavanca conectada estava corroído, impedindo assim qualquer mudança que fosse. Mesmo neste nível pode haver opacidade junto a relação objeto-tecnologia.

O propósito desta patologia, de alguma forma prematura das relações humano-tecnologia, não é o de lançar uma luz negativa sobre as relações hermenêuticas 
em detrimento às relações de incorporação, mas, ao contrário, indicar que existem localizações diferentes em que as relações perceptiva e humano-tecnologia interagem. Normalmente, quando as tecnologias trabalham, a relação tecnologia-mundo pode manter sua transparência hermenêutica única. Mas se a relação eu-(tecnologia-mundo) estiver longe o suficiente do continuum para identificar a relação como sendo do tipo hermenêutica, a interseção das relações corporal-perceptual junto à tecnologia muda.

Tecnologias que podem ser lidas demandam uma extensão das minhas capacidades hermenêuticas e "linguísticas" através dos instrumentos, enquanto a leitura em si guarda sua localização perceptual corpórea como sendo a relação com ou em direção à tecnologia. O que está imergindo aqui é a primeira sugestão de uma emergência da tecnologia como sendo um "objeto", mas sem a conotação negativa heideggeriana. De fato, o tipo de capacidade especial como a do "texto" é a condição para a transparência hermenêutica.

A transformação tornada possível pela relação hermenêutica é a transformação que ocorre precisamente por meio das diferenças entre o texto e aquilo a que ele se refere. O que é necessário é o conjunto particular das percepções textuais claras que "reduzem" para o que é imediatamente legível. Para volta ao exemplo de Three Mile Island, um problema descoberto foi que o design do painel instrumental em si estava com defeito. Ele não incorporou seus mostradores e indicadores de uma forma facilmente legível. Por exemplo, no design do painel instrumental do avião, muita atenção tem sido dada ao reconhecimento de padrões, que ocorrem como sendo uma forma perceptual. Assim, em aviões com quatro motores, os quatro mostradores que indicam RPM serão coordenados de forma que um simples relance vai indicar qual dos motores, se algum deles estiver, se encontra fora de sincronização. Tal design técnico leva em conta as estruturas perceptuais.

Há uma segunda precaução no que diz respeito ao foco sobre os conectores e a patologia. Em todos os exemplos que eu usei até este ponto, as técnicas hermenêuticas envolveram conexões materiais. ( $\mathrm{O}$ termômetro emprega uma propriedade física da mola bimetálica ou do mercúrio em uma coluna; o painel instrumental da usina nuclear emprega conexões mecânicas, elétricas ou outros tipos de conexões materiais; a alavanca de marchas, uma conexão mecânica simples.) Se a leitura não emprega nenhum tipo de conexão material, pode-se observar que sua referencialidade é essencialmente diferente, ainda que nem todas as conexões tecnológicas sejam estritamente materiais. A fotografia 
guarda um isomorfismo representacional junto ao objeto, ainda que não esteja "materialmente" conectada com seu objeto; trata-se de um início mínimo de ação à distância.

Eu tenho usado exemplos contemporâneos ou pós-científicos, mas as relações não materiais hermenêuticas não são obtidas apenas a partir de humanos contemporâneos. Como relações existenciais, elas são tão "antigas" quanto a humanidade pós-Éden. A antropologia e a história das religiões desde muito tempo tem familiaridade com uma ampla variedade de práticas xamânicas que recaem no padrão das técnicas hermenêuticas. No que pode parecer à primeira vista um conjunto um tanto chocante de exemplos, note as várias técnicas de "leitura" empregadas no xamanismo. A leitura das entranhas de um animal, ou lançar ossos, ou marcas corporais são todas técnicas hermenêuticas. O padrão das entranhas, ossos, ou o que quer que seja tomado para referir-se a algum estado de coisas, instrumentalmente ou textualmente.

Não apenas estamos próximos aqui de uma associação familiar entre magia e origens da tecnologia sugeridas por muitos escritores, mas estamos, de fato, próximos a uma ampla práxis hermenêutica em uma definição intercultural. Por essa razão, a própria estranheza da prática precisa ser criticamente examinada. Se o lançamento de ossos é tomado como uma forma "primitiva" de diagnóstico médico, a qual desempenha um papel no xamanismo, pode-se concluir que esta é, de fato, uma forma precária de relações hermenêuticas. O que podemos estar deixando passar, no entanto, é que toda a formatação do que está sendo diagnosticado pode diferir radicalmente desta outra cultura para a nossa.

Pode muito bem ser que como uma forma focada de diagnóstico sobre alguma doença corporal específica (apendicite, por exemplo), o diagnóstico vai falhar. Mas já que um importante elemento do xamanismo é o diagnóstico amplo, utilizado principalmente como forma de localizar certos problemas comuns ou sociais, ele pode funcionar melhor. A ênfase muitas vezes descontextualizada da medicina ocidental sobre um corpo presumivelmente "mecânico" pode negligenciar precisamente o contexto que o xamã tão claramente reconhece. Toda a forma de mundo é diferente e diferentemente focada, mas em ambos os caos existem exemplos de relações hermenêuticas.

No nosso caso, o próprio sucesso da medicina ocidental sobre certas doenças se deve à introdução de tecnologias às relações hermenêuticas (febre/termômetro; pressão arterial/esfigmomanômetro, etc.) O ponto é que estas relações 
hermenêuticas são um lugar comum nos grupos sociais tradicionais e ancestrais e nos nossos, mesmo que eles sejam diferentemente organizados e praticados.

Ao continuar a análise de intencionalidade que tenho seguido, pode-se agora ver que as relações hermenêuticas alteram o continuum das relações humano-tecnologia-mundo. Relações hermenêuticas mantêm a posição geral de mediação das tecnologias junto ao contexto da práxis humana frente ao mundo, mas elas também alteram as variáveis junto à relação humano-tecnologia-mundo. Um formalismo comparativo pode ser sugerido:

\section{Relações gerais de intencionalidade Humano-tecnologia-mundo}
Variante A: relações de incorporação (eu-tecnologia) $\rightarrow$ mundo
Variante B: relações hermenêuticas eu $\rightarrow$ (tecnologia-mundo)

Enquanto cada componente da relação mundo junto à correlação, as formas gerais das variantes são distinguíveis. Também não são estas questões sobre como as tecnologias são simplesmente vivenciadas.

Outro conjunto de exemplos do âmbito dos instrumentos óticos pode ilustrar ainda outra forma pela qual as intencionalidades instrumentais podem seguir novas trajetórias. Pode-se dizer que relações estritamente de incorporação operam melhor quando existe igualmente uma transparência e um isomorfismo entre o perceptual e a ação corporal junto à relação. Eu tenho sugerido que a trajetória para o desenvolvimento, em tais casos, pode ser comumente horizontal. Tal trajetória não apenas acompanha maiores níveis de ampliação, mas também envolve todas as dificuldades de natureza técnica que possibilitarão o que está para ser visto como sendo uma visão direta. Mas nem todas as óticas seguem esta estratégia. A introdução da hermenêutica possibilita abrir a trajetória rumo ao que denominarei direções verticais, possibilidades que dependem deliberadamente de transformações hermenêuticas.

Pode-se dizer que o telescópio e o microscópio, ao ampliar a visão enquanto a transformam, permanecem tecnologias análogas. O aprimoramento e a ampliação tornados possíveis por tais tecnologias continuam visuais e transparentes 
para a visão ordinária. A lua continua reconhecível como lua, e o micróbio, mesmo que previamente não se suspeitasse de sua existência, continua sob o microscópio reconhecido como um ser pertencente ao continuum animado. Aqui, tal como a capacidade de ampliar se torna o fenômeno em primeiro plano para o fenômeno em segundo plano da redução que necessariamente acompanha a ampliação, assim a similitude do que é visto com a visão ordinária continua central para as relações de incorporação.

Nem todas as tecnologias óticas mediam tais percepções. Progressivamente, no "alfabeto" visual da relação hermenêutica, variações deliberadas podem ocorrer aumentando as diferenças anteriormente indiscerníveis:

1. Imagine o uso de óculos para corrigir a visão, tal como observado acima. O que se procura é o retorno à visão o máximo possível para a percepção ordinária, não distorcer ou modificá-la em nenhum extremo, seja em direções micro ou macroperceptivas. Mas agora, para paisagens cobertas de neve ou para o sol refletido na água, ou para o deserto, nós modificamos as lentes colorindo-as ou polarizando-as para diminuir o brilho. Tal variação transforma $o$ que é visto em algum nível. Quer dizer que a lente polarizada remove o brilho ou "escurece" a paisagem, o que se percebe agora é claramente diferente daquilo que pode ser visto através dos óculos sem tal tingimento. Esta diferença é uma pista que pode abrir uma nova direção teleológica para a investigação.

2. Agora digamos que em algum lugar, em algum tempo, alguém observa que certos tipos de tingimentos revelam resultados inesperados. Tal é que uma técnica muito mais complexa usada hoje em fotos infravermelhas de satélites. (Para o momento, ignorarei o fato de que parte deste processo é a relação hermenêutica e incorporada combinadas.) Se a foto é da península da Baja Califórnia, ela continuará reconhecível em sua forma. Geograficamente, qualquer profundidade e representação de altura etc., permanece, mas varia em uma direção diferente de qualquer visão ordinária. As fotos infravermelhas destacam a diferença entre vegetação e não vegetação para além dos limites de qualquer fotografia colorida isomórfica. Esta diferença corresponde, num exemplo análogo, a algo como a pictografia. Simultaneamente, ela deixa certas estruturas análogas ali e começa a modificar a representação em uma "representação" diferente, não percebida.

3. Versões muito sofisticadas das ainda representativas mas não ordinárias formas do reconhecimento visual ocorrem nas novas tecnologias termográficas 
e computadorizadas empregadas pelos militares e pela polícia. Imagens noturnas que evidenciam a radiação de calor de uma pessoa ainda se parecem com uma pessoa mais com regiões inteiramente diferentes do que se destaca e do que recua. Em observações de alta altitude, "sombras quentes" no terreno podem indicar um avião que recentemente teve suas turbinas acionadas em comparação a outros que não tiveram. Aqui, tecnologias visuais levam para a visibilidade o que não era visível, mas de maneira distinta numa forma agora perceptível.

4. Se agora tomar-se um passo muito mais largo em direção à espectroscopia astronômica, pode-se ver a aceleração deste desenvolvimento. A figura espectroscópica de uma estrela já não "se assemelha" de forma alguma à estrela. Não há ponto de luz, não há tamanho da esfera, e de modo algum isomorfismo espacial, há meramente a faixa das listras coloridas do arco-íris. O leitor leigo não saberia que isto é a imagem de estrela de forma alguma, o leitor precisaria conhecer a linguagem, o alfabeto, os quais codificaram a estrela. $\mathrm{O}$ astrônomo-hermeneuta conhece a linguagem e "lê" os visuais "ABCs" de um modo que conhece a composição química da estrela, sua composição interna, em vez de sua forma ou configuração externa. Nós estamos aqui na presença de uma relação hermenêutica mais completa, a estrela mediada não apenas instrumentalmente, mas em uma transformação tal que nós devemos agora ler tematicamente o resultado. E apenas o leitor informado pode fazer a leitura.

Permanece, é claro, a referência à estrela. O espectrógrafo é de Rigel ou de Polaris, mas a individualidade da estrela agora se faz presente hermeneuticamente. Aqui nós temos o começo de uma transformação especial da percepção, a transformação que deliberadamente aumenta as diferenças em vez das similaridades em ordem de obter o que era previamente ignorado.

5. Mesmo que ainda o espectrógrafo seja uma transformação mais radical da percepção, ele pode, também, ser alterado por uma analogia hermenêutica ainda mais radical para a transformação digital que se encontra incorporado na práxis quantitativa preferida da ciência. O "alfabeto" matemático da ciência é claro, a matemática que separa a si mesma por meio de ainda outro passo hermenêutico da percepção incorporada.

Existem muitas formas nas quais esta transformação pode e de fato ocorre, a maioria delas curiosamente envolvendo um ato particular de tradução que 
frequentemente fica incógnito. Para manter o exemplo o mais simples possível, deixe-nos assumir a "tradução" mecânica ou eletrônica. Suponha que nosso espectrógrafo é lido por uma máquina que prefere não o espectro do arco-íris, mas um conjunto de números. Aqui nós chegaríamos à realização hermenêutica definitiva, a transformação do próprio análogo a um dígito. Mas neste processo de hermeneutização, a "transparência" para o objeto referido torna-se enigmática. Aqui uma interpretação mais explícita e mais temática deve ocorrer.

Relações hermenêuticas, particularmente aquelas que utilizam tecnologias que permitem transformações verticais, se distanciam do isomorfismo perceptual. É a diferença entre o que é mostrado e como algo é mostrado que é informativa. Numa relação hermenêutica, o mundo é primeiramente transformado num texto, que por sua vez é lido. Existe potencialmente tanta flexibilidade junto às relações hermenêuticas quanto existe nos vários usos da linguagem. Emmanuel Mounier reconheceu inicialmente precisamente esta relação analógica com a linguagem:

A máquina, enquanto implemento, não é a simples extensão material de nossos membros. Ela é de outra ordem, um anexo para a nossa linguagem, uma linguagem auxiliar para a matemática, um meio de penetração, dissecação e revelação do segredo das coisas, suas intenções implícitas, suas capacidades inexploradas. ${ }^{4}$

Por meio das relações hermenêuticas podemos, por assim dizer, ler nós mesmos junto a qualquer situação possível sem estar lá. Na ciência, em contraste à literatura, o que é importante é a leitura resguardar algum tipo de referência ou transparência hermenêutica para com o que está lá. Talvez esta seja uma razão para o desejo constante de reverter o que é lido de volta para o que pode ser percebido. Nesta reversão, a ciência contemporânea tecnologicamente incorporada frequentemente tem derivado o que pode ser chamado tecnologias de tradução. Eu menciono duas nesta passagem:

(a) Processos digitais têm se tornado comuns junto ao domínio perceptual. O advento das imagens do espaço provam que tal processo é uma dupla tradução. A fotografia da superfície de Vênus é tecnologicamente análoga à visão humana. É ao menos o campo de exibição da superfície, incorporando as várias imagens possíveis e contrastes que seriam vistos instantaneamente na forma visual, mas

4 MOURNIER, Emmanuel. Be Not Afraid, trans. Cynthia Rowland. London: Rockcliffe, 1951, p. 195. 
este resultado holístico não pode ser transmitido desta maneira pelas tecnologias atuais. Assim, a imagem é "traduzida" em um código digital, que pode ser transmitido. A "visão" do instrumento é decodificada numa série de dígitos que são radiograficamente transmitidos para um receptor; então eles são recodificados em um padrão diluído e ampliados para reproduzir a fotografia obtida de milhões de quilômetros de distância. Seria virtualmente impossível para alguém ler os dígitos e dizer o que era para ser visto; apenas quando o texto linear dos dígitos estiver retraduzido novamente na expansão de forma visual instantânea pode-se ver que as rochas sobre Vênus são ou não iguais àquelas sobre a lua. Aqui a analogia da percepção e da linguagem são igualmente utilizadas para ampliar a visão para além da terra.

(b) O mesmo processo é utilizado acusticamente em gravações digitais. Novamente, o processo de dupla tradução é utilizado e o som é reduzido para a forma digital, reproduzido através da gravação, e traduzido novamente em uma forma audível.

Processos digitais e análogos confundem-se em certas configurações. Fotografias transmitidas como pontos de preto em um fundo branco e remontados dentro de certos limites são perceptivamente formatadas; nós vemos Humphrey Bogart não apenas como um simples mosaico de pontos. (O pontilhismo faz o mesmo na pintura, embora em cores. A assim chamada poesia concreta emprega o mesmo cruzamento, colocando as palavras do poema em um padrão visual e então o poema pode ser igualmente lido e visto como um padrão visual.)

Tais processos de tradução e retradução são claramente transformações do fenômeno da forma perceptiva em analogias da escrita (processos de tradução e retradução periódicos são claramente transformações do fenômeno da forma perceptual em analogias dos padrões de escrita junto à "linha", por assim dizer), que são então retraduzíeis em formas perceptuais.

Eu tenho sugerido que o movimento a partir das relações de incorporação para as relações hermenêuticas ocorrem junto ao continuum do humano-tecnologia. Assim como existem complicações, casos de fronteira ao longo do continuum entre totalmente cabeludo e homens calvos, existem as mesmas diferenças não tão dramáticas aqui. Eu tenho destacado algumas destas diferenças ao acentuar as distinções corpórea-perceptuais que ocorrem entre as relações de incorporação e hermenêuticas. Isso possibilitou que as diferenças em transparências perceptuais e hermenêuticas se destacassem. 
Restam ainda duas confusões possíveis que precisam ser clarificadas antes de darmos o próximo passo na fenomenologia da técnica. Primeiro, há um sentido relacionado no qual a percepção e a interpretação estão entrelaçados. A percepção já é primitivamente interpretativa, igualmente nas suas micro e macrodimensões. Perceber já é algo "como" ler. Ainda que a leitura seja também um ato especializado que recebe igualmente uma definição futura e elaboração junto aos contextos literários. Tenho afirmado que uma das diferenças distintivas entre relações de incorporação e hermenêuticas envolvem uma posição perceptiva, mas, em amplo sentido, a interpretação permeia igualmente a ação de incorporação e a hermenêutica.

Uma segunda confusão proximamente relacionada implica o duplo sentido no qual uma tecnologia pode ser usada. Ela pode ser usada simultaneamente igualmente como algo através do qual se vivencia e como algo que está relacionado com alguém. Enquanto isto é assim, a dupla relação toma forma numa incorporação diferente daquelas próprias das relações hermenêuticas. Voltando às simples relações de incorporação ilustradas pelo exemplo de se usar os óculos, focalmente, minha experiência perceptiva encontra seu alvo direcional através das lentes, finalizando o meu olhar sobre o objeto da visão; mas como um fenômeno marginal, eu estou simultaneamente consciente (ou posso ficar consciente) da forma como meus óculos repousam sobre o dorso do meu nariz e sobre a hélice da minha orelha. Nesse sentido marginal, estou consciente dos óculos, mas o fenômeno focal é a transparência perceptual que os óculos possibilitam.

Nos casos de transparência hermenêutica, esta dupla função é subitamente alterada. Agora eu preciso ler cuidadosamente os indicadores junto ao núcleo do meu campo visual e prestar atenção neles. Mas minha leitura é simultaneamente uma leitura por meio deles, embora agora o terminus da referência não seja necessariamente o objeto perceptual, e nem esta, estritamente falando, perceptivamente presente. Enquanto o tipo de transparência é distinto, o propósito da leitura continua sendo o de obter transparência hermenêutica.

Ambas as relações, no entanto, em seu melhor, ocorrem junto à práxis aquisitiva familiar do mundo da vida. A visão perceptiva apurada precisa ser aprendida e, uma vez adquirida, ocorre como sendo familiar ao ato de enxergar em si. Para o leitor maduro e crítico, a transparência hermenêutica de algum conjunto de instrumentos é tão clara e imediata tal como o exame visual de alguma espécie. A peculiaridade da transparência hermenêutica não repousa em alguma realização deliberada e nem num esforço de interpretação (embora na 
aprendizagem de algum texto novo ou linguagem, este esforço se faça aparente). Isto é o porquê da práxis que cresce junto ao contexto hermenêutico manter o mesmo senso de espontaneidade que ocorre nos simples atos de mobilidade corporal. Mesmo assim, uma presença mais distintiva da tecnologia surge no exemplo. Minha consciência do painel instrumental é igualmente forte e centrada mais focalmente do que a consciência de borda sobre a armação dos óculos, e esta consciência mais distinta é essencial ao uso otimizado da instrumentação.

Em ambas as relações, de incorporação e hermenêutica, no entanto, a tecnologia permanece aquém da plena objetividade ou de outra forma. Ela continua o meio através do qual algo mais se faz presente. A caracterização negativa que possa ocorrer em patologias extremas pode retornar. Quando a tecnologia na posição de incorporação se quebra ou quando a instrumentalização na posição hermenêutica falha, o que permanece é um obstrutivo, e desta forma negativamente derivado, objeto.

Tanto nas relações de incorporação e hermenêutica, enquanto agora distinguidas, permanecem as relações existenciais básicas entre o usuário humano e o mundo. Existe o perigo de que meu agora-constante e seletivo uso da instrumentalização científica possa distorcer o impacto total da dimensão existencial. Antes de ir adiante junto ao continuum humano-tecnologia-mundo, devo rapidamente examinar um conjunto bem diferente de exemplos instrumentais. A instrumentalização neste caso será a instrumentalização musical.

No sentido mais geral, deveria ser fácil ver que o uso de instrumentação musical, nas performances, recai nas mesmas configurações que as dos instrumentos científicos:

\section{eu-instrumento musical-mundo \\ eu-instrumento científico-mundo}

Mas o contexto praxiológico é significativamente alterado. Se a práxis científica ou de produção de conhecimento for contrastada pela necessidade de se ter um terminus referencial junto ao mundo, a práxis musical não é tão limitada. De fato, se há um terminus, ele é a referência não tanto para alguma coisa ou região do ambiente, mas para a produção de um evento musical junto ao ambiente. O "objeto musical" é qualquer fenômeno de som que ocorra através da performance sobre o instrumento. Os sons musicais são produzidos, criados. Enquanto que no desenvolvimento da instrumentação científica a precaução 
sobre o fenômeno que poderia ser uma afetação do instrumento em vez de seu referente, estão para ser evitados ou reduzidos o quanto for possível, a própria descoberta e o aprimoramento de tais artefatos instrumentais podem ser um fenômeno positivo na produção musical. Existem significantes e interessantes diferenças nestes dois contextos relativos à práxis, mas, para o momento, devo restringir-me ao conjunto de observações sobre as similaridades nas estruturas de intencionalidade tanto da instrumentação científica quanto musical.

Deveria ser óbvio que o amplo uso de instrumentação musical recai facilmente no padrão da relação de incorporação. O músico escolhe o instrumento (tendo aprendido como incorporá-lo) e expressamente produz a música desejada:

músico-instrumento-som

Nos casos de incorporação, o instrumento fazendo o som será parcialmente simbioticamente incorporado:

$$
\text { (músico-instrumento)-som }
$$

Segundo, a anteriormente notada estrutura de ampliação/redução também ocorre aqui. Se nosso músico é um trombonista, o "zumbido" que a vibração de seus lábios produz pode ser ouvido sem qualquer instrumento, mas, uma vez ampliado e transformado através do trombone, se dá como um som musical distinto para o conjunto humano-instrumento. De maneira imediatamente similar, ao menos junto ao complexo da instrumentação contemporânea, pode-se detectar que nada é uma restrição para o som humano tal como pertencente ao contexto musical contemporâneo. Isomorfismo para o som humano, enquanto historicamente desempenhando um significante papel cultural, agora ocupando apenas uma dimensão do som musical.

Esta história, no entanto, é interessante. Têm existido tendências na história musical do Ocidente para restringir junto a ou até mesmo para desenvolver precisamente de acordo com formas variáveis horizontalmente. A restrição do som musical às vozes humanas reais (certas seitas menonitas não permitem qualquer tipo de instrumentação musical, e todos os hinos cantados são feitos a cappella) é uma forma desta tendência. Instrumentação que imite ou de fato amplifique os sons vocais e seus alcances é outro exemplo: sopros, trombetas, órgãos (até mesmo para as pausas dos órgãos que são análogas às vozes usuais) todos são instrumentos antigos que frequente e deliberadamente seguem um 
tipo de isomorfismo vocal. A música medieval era usualmente duplamente delimitada. Não apenas a música deveria manter-se junto ao alcance da similitude humana, mas até mesmo as harmônicas normativamente controladas e linhas de canto foram religiosa e culturalmente determinadas. Depois, pode-se detectar um modelo muito mais vocal, uma música muito mais italiana (Renascença até o Barroco) em contraste ao mais instrumentalmente orientado modelo de música germânica.

O modelo valorativo implícito da voz humana também foi refletido na história musical do Ocidente pela classificação dos instrumentos de acordo com sua expressividade, com aqueles instrumentos que se pensava serem os mais expressivos como o violino, por exemplo, serem classificados mais alto do que aqueles mais distantes do modelo vocal.

A diferença entre as relações de incorporação e hermenêuticas aparecem também junto a este contexto. Enquanto as relações de incorporação no sentido existencial mais geral não necessita ser estritamente delimitado pelo isomorfismo, as variações hermenêuticas ocorrem muito rapidamente junto ao espectro musical. O piano apresenta pouco isomorfismo vocal; ainda que quando tocado, ele recai numa relação de incorporação, é expressão do estilo individual e realização de quem executa a performance, etc. Mais adiante o continuum, nas músicas produzidas por processo de computação claramente ocorrem muito mais completas junto ao alcance das relações hermenêuticas, em alguns casos com a emergência da geração de um som aleatório muito próximo ao senso da alteridade, que vai caracterizar o próximo conjunto de relações onde a tecnologia emerge como outro.

Música instrumental, como técnica, pode seguir tanto na direção de incorporação ou hermenêutica. Ela pode desenvolver sua instrumentação igualmente em trajetórias horizontal ou vertical. Em qualquer direção existem transformações tecnológicas claramente reconhecíveis. Se o modelo ocidental "biônico" da música primitiva foi a voz, na música andina ele foi o canto do pássaro (tanto em melodia quanto em qualidade sonora produzida pelas flautas de sopro de madeira). Contrariamente, a instrumentação da percussão (música de bateria e comunicação) foi, desde o início, um movimento no sentido vertical e assim numa direção mais hermenêutica. Esta exploração da possibilidade de explorar as árvores em direções vertical e horizontal pertence ao reino tanto da práxis musical quanto da práxis científica, mas se dá sem nenhuma referência ao mundo natural. 
O resultado do desenvolvimento tecnológico nas técnicas musicais é também sugestivamente diferente do que resulta na práxis científica. $\mathrm{O}$ "mundo" produzido musicalmente por meio de todas as prefigurações técnicas não é aquele sugerido tanto pela nova filosofia da ciência ou pela filosofia da tecnologia heideggeriana. A analogia próxima à noção de reserva disponível (fonte de recursos) que o "mundo" musical pode alcançar é aquele reino de todos os sons possíveis que possam ser alcançados e/ou transformados musicalmente. Mas os recursos acústicos da técnica musical são utilizados por meio do senso criativo do tocar o que permeia a práxis musical. O "objetivo musical” é o objeto criado, mas sua criação não é delimitada pelos mesmos imperativos da práxis científica, ainda que a materialização do som musical através da instrumentação mantenha-se uma forma de ação tecnológica plenamente humana.

O que pode ser vislumbrado neste desvio para a instrumentação musical é que enquanto as estruturas humano-tecnologia são paralelas com aquelas encontradas junto à instrumentação científica, o "mundo" criado não implica de forma alguma a mesma redução para o que tem sido considerado como sendo a visão ocidental peculiar da dominação da natureza. Aqui, então, há uma abertura para a possibilidade de uma trajetória diferente de desenvolvimento.

\section{Relações de alteridade}

Para além das relações hermenêuticas existem as relações de alteridade. As primeiras indicações de tais relações, as quais eu devo caracterizar para ou junto à tecnologia, já tem sido sugerida de maneiras diferentes a partir e junto aos contextos de incorporação e hermenêutico. Junto às relações de incorporação, em que a tecnologia é invasiva antes de ser um facilitador da percepção e extensão corpórea junto ao mundo, a objetividade da tecnologia teria necessariamente surgido de forma negativa. Junto às relações hermenêuticas, no entanto, surge certa positividade diante da objetividade das tecnologias instrumentais. O foco corpóreo-perceptivo sobre o texto instrumental é a condição de sua própria transparência hermenêutica peculiar. Mas o que há no senso positivo ou presencial das relações com tecnologias? Em quais sentidos fenomenológicos a tecnologia pode ser outro?

A análise aqui pode parecer estranha para alguém limitado à descrição das perspectivas objetivistas, pelo fato de que em tais descrições as tecnologias, enquanto objetos, usualmente vêm primeiro antes de vir depois. O problema para 
uma descrição fenomenológica é que os objetivistas são não relativistas e assim perdem ou submergem o que é distintivo sobre as relações humano-tecnologia.

Uma descrição objetivista ingênua pode preferir iniciar com alguma tentativa de circunscrever ou definir as tecnologias por suas características objetivas. Então, o que eu tenho chamado de propriedades técnicas das tecnologias pode se tornar o foco. Alguma combinação das propriedades físicas e materiais pode ser tomada para servir como elemento de definição. (Esta é uma tendência inerente das posições nomológicas-padrão tais como as de Bunge e Hacking). A definição irá comumente servir a um propósito secundário ao ser estipulativa: apenas aquelas tecnologias que são obviamente dependentes junto às práticas produtivas científicas contemporâneas e industriais ou fortemente relacionadas a elas é que contarão.

Isto é negar que as descrições objetivistas têm suas próprias forças distintivas. Por exemplo, muitas destas descrições reconhecem que os produtos tecnológicos ou "artificiais" são diferentes dos objetos simplesmente encontrados ou dos objetos naturais. Mas a submergência da relação humano-tecnologia continua oculta, desde que objetos possam adentrar junto à práxis e ambos tenham o seu material e, assim limitado, alcance de usabilidade técnica junto às relações. E nem isto é negar que as descrições objetivistas dos tipos de tecnologias, tipos de organização ou tipos de propósitos projetados devam ser considerados. Mas o foco neste primeiro programa continua a derivação fenomenológica do conjunto das relações humano-tecnologia.

Há uma tática por trás do fato de eu colocar as relações de alteridade por último na ordem focal das relações humano-tecnologia. A tática é projetada, por um lado, para lograr a tendência na qual sucumbiu Heidegger e seus seguidores mais ortodoxos em ver a alteridade da tecnologia apenas em seus aspectos negativos ou através de derivações negativas. O exemplo do martelo, que continua paradigmático para esta abordagem, é um exemplo que deriva a objetividade a partir do mau funcionamento. A tecnologia quebrada, ausente ou defeituosa pode ser descartada. Ao ser uma obstrução ela pode tornar-se sucata. Sua objetividade pode ainda ser clara, mas apenas parcialmente. A sucata não é um objeto focal de uso das relações (exceto em certas situações limitadas). Ele é mais ordinariamente um fenômeno de fundo, o qual foi colocado fora de uso.

E, por outro lado, também não desejo recair numa descrição objetivista ingênua que iria simplesmente concentrar-se sobre as propriedades materiais da tecnologia como sendo um objeto do conhecimento. Tal descrição submergiria 
a relatividade da análise da intencionalidade, a qual eu desejo preservar aqui. $\mathrm{O}$ que é necessário é uma análise dos sentidos positivos ou presenciais nos quais os humanos se relacionam com as tecnologias como relações para ou com tecnologias, a tecnologia-como-outro. É neste sentido que se inclui o termo "alteridade".

Filosoficamente, o termo "alteridade" é emprestado de Emmanuel Levinas. Apesar de Levinas manter-se fiel às tradições da fenomenologia e hermenêutica, seu distinto trabalho, Totalidade e Infinito, foi "anti-heideggeriano". Naquele trabalho, o termo "alteridade" vem a significar a diferença radical colocada para qualquer humano por outro humano, um outro (e o outro em última análise, Deus). Extrapolando radicalmente a partir da ênfase da tradição sobre a não redutibilidade do humano nem sua objetividade (na epistemologia) ou como sendo um meio (na ética), Levinas posiciona a alteridade dos humanos como sendo um tipo de diferença infinita que é concretamente expressada em um encontro ético, face a face.

Eu devo manter, porém modificar, este sentido radical levinasiano da alteridade humana ao voltar-me para uma análise das relações humano-tecnologia. Como e em que medida as tecnologias se tornam outro, ou, ao menos, quase outro? No cerne desta questão repousa todo um conjunto de séries de interpretações bem-reconhecidas, porém problemáticas, das tecnologias. De um lado repousa o problema familiar do antropomorfismo, a personalização dos artefatos. Este alcance do antropomorfismo pode ser alcançado a partir de sérias analogias artefato-humano até de triviais e inofensivas afecções por artefatos.

Um exemplo das sérias analogias encontra-se incorporado em muito da pesquisa sobre Inteligência Artificial. Caracterizar a "inteligência” do computador como sendo análoga à humana é recair num tipo de antropomorfismo peculiar contemporâneo, contudo, sofisticado. Um exemplo do antropomorfismo trivial é encontrar alguém "afeiçoado" por algum tipo peculiar de tecnofato, tal como um cuidado excessivo por um automóvel que se deseja que continue andando e que possa ser caracterizado por termos deliberadamente bastante antropomórficos. Similarmente, em culturas antigas ou não ocidentais, o papel de sacralidade atribuído a artefatos exemplifica outra forma deste fenômeno.

O objeto religioso (ídolo) não apenas simplesmente "representa" algum poder perdido, mas é dotado com o sagrado. Sua aura de sacralidade está espacialmente e temporalmente presente junto ao alcance de sua eficácia. O devoto tribal vai defender, sacrificar por e zelar pelo artefato sagrado. Cada uma destas ilustrações contém as sementes de uma relação de alteridade. 
Uma abordagem menos direta ao que é distintivo nas relações de alteridade humano-tecnologia pode talvez abrir melhor o campinho para a análise fenomenologicamente relativística. Meu primeiro exemplo vem a partir da comparação de uma tecnologia a um animal "utilizado" em algum contexto prático (embora possivelmente esportiva): o cavalo espirituoso e o carro esportivo animado.

Cavalgar um cavalo espirituoso é encontrar um vivido animal outro. Em seu contexto pré-humano ou nãohumano, o cavalo possui uma vida que lhe é própria junto ao ambiente que possibilita esta forma de vida. Uma vez domesticado, o cavalo pode ser "utilizado" como sendo um "instrumento" da práxis humana, mas apenas para um grau e de uma maneira diferente das tecnologias em contrapartida; neste caso, o carro esportivo "animado".

Existem, é claro, analogias que podem a princípio destacar-se. Igualmente cavalo e carro dão ao cavaleiro/motorista um ampliado senso de poder. A velocidade e a experiência da velocidade alcançada em cavalgar/dirigir são extensões profundas das minhas próprias capacidades. Alguns aspectos proeminentes das relações de incorporação podem ser encontrados analogamente em cavalgar/dirigir. Eu vivencio a trilha/estrada por meio do cavalo/carro e conduzo/dirijo a entidade mediadora diante do caminho. Mas existem igualmente proeminentes diferenças. Não importa quão bem treinados, nenhum cavalo apresenta a mesma "obediência" que o carro. Tome o mau funcionamento: no carro, o defeito "resiste" aos meus comandos, eu piso no acelerador e, devido a um afogamento, não há as respostas que eu espero. Mas a resistência animada do cavalo espirituoso é mais que uma falha mecânica de resposta, a resposta é mais que mau funcionamento, ela é desobediência. (Os cavaleiros mais experientes, de fato, preferem os cavalos espirituosos sobre os mais passivos, o que pode mais perto aproximar-se de uma obediência mecânica.) Esta vida do outro em um cavalo pode ser levada muito adiante, ele pode viver sem mim no ambiente adequado; ele não precisa da intervenção deística ou que se ligue a ignição para ser "animado". O carro não vai intimidar-se com o coelho surgindo no caminho, não mais do que os cavalos obedecerão ao "comando" do motorista para bater no muro de pedra quando ele estiver muito embriagado para dar-se conta. $\mathrm{O}$ cavalo, quando aproximado a certos aspectos da situação de incorporação mediada, nunca participa totalmente da relação no sentido em que uma tecnologia o faz. Nem o carro jamais atinge o senso de animação que pode ser encontrado cavalgando. Ainda que a analogia seja tão profundamente incorporada em nossas consciências contemporâneas (e talvez a falta de experiência suficiente 
com cavalos ajude) que nós possamos ser tentados a enfatizar as similaridades aos invés das diferenças.

Por um lado, o antropomorfismo no que diz respeito à tecnologia e, por outro, o contraste da montaria com a primeira aproximação a um tipo único de alteridade que as relações para a tecnologia mantêm. Alteridade tecnológica é uma quase alteridade, mais forte que a mera objetividade, mas mais fraca que a alteridade encontrada junto ao reino animal ou humano; a derivação tecnológica precisa, entretanto, focar-se sobre os aspectos experimentais positivos delineando esta relação.

Ainda em outro fenômeno familiar, vivenciamos tecnologias na forma de brinquedos desde a infância. Um amplo exemplo transcultural é o do pião. Antes de ser colocado em uso, o pião pode ser encontrado como um objeto desequilibrado junto a certa simetria de design (mesmo os primeiros piões se aproximavam do mais dos designs funcionais mais puros de otimização, etc.), mas uma vez "deisticamente" animados através do movimento da vareta ou do puxão da corda, o agora pião girando parece ter ganhado vida por si próprio. Sobre sua extremidade (ou "pé"), o pião parece desafiar seu desequilíbrio e a própria gravidade. Ele traça imprevisíveis movimentos ao longo de seu caminho. Ele é um objeto de fascinação.

Note que uma vez que o pião é posto para girar, aquilo que foi comunicado através de uma relação de incorporação agora o excede. O que faz dele fascinante é a propriedade de quase animação, a própria vida. Ademais, evidentemente, uma vez "automático" em seu movimento, os movimentos do pião podem ter adentrado em toda uma nova série de contextos possíveis. Ele pode entrar numa competição de piões no qual o meu (apropriadamente identificado) me representa. Se eu-sendo-o-pião obtenho sucesso em derrubar os outros piões, então este jogo de hermenêuticas teve o pião vencedor para mim. Similarmente, se eu tomar seu movimento quase autônomo para ser meu preditor hermenêutico, posso adentrar num contexto de adivinhação no qual o caminho traçado e o ponto eventual de parada indicam alguma sorte. Ou, adentrando no campo da instrumentação científica, eu posso transformar o pião num giroscópio, usando sua constância de direção junto a sua raia agora sobcontrole como sendo uma bússola melhor que a magnética. Mas em cada um destes casos o pião pode tornar-se o centro focal da atenção como sendo o quase outro ao qual eu posso me relatar. $\mathrm{O}$ objeto de fascinação não precisa carregar uma incorporação e nem uma transparência hermenêutica referencial. 
Do pião antigo ao contemporâneo, compare brevemente a fascinação que ocorre junto aos videogames. No uso atual dos videogames, é claro, as dimensões de incorporação e de relação hermenêuticas estão presentes. O controle que incorpora habilidades de coordenação de mãos e olhos proporciona a extensão do jogador junto ao campo apresentado. O campo em si apresenta algum contexto hermenêutico (usualmente algum minimundo "invasivo" ou algum tipo análogo de esportes), mas este contexto não se refere para além de si mesmo junto a uma referência mundana.

Somando-se a estas dimensões, no entanto, há um senso de interagindo com alguma coisa outra que não eu, o competidor tecnológico. Na competição há uma espécie de diálogo ou permuta. Isto é a quase animação, a quase alteridade da tecnologia que fascina e desafia. Eu preciso derrotar a máquina ou ela vai me derrotar.

Em cada um dos casos mencionados, aspectos da alteridade tecnológica se fizeram aparentes. A quase alteridade, a quase autonomia que aparece no brinquedo ou no game é a variante sobre as tecnologias que tem fascinado os pensadores ocidentes ao longo dos séculos, o autômato.

As tecnologias gregas mais sofisticadas (e similarmente, as chinesas) não aparecem em contextos práticos ou científicos tão frequentemente quanto nos contextos de jogo ou teatrais. (Contextos bélicos, é claro, sempre têm empregado tecnologias avançadas.) Junto a esses contextos, autômatos foram inventados. A partir da redescoberta de tratados de Heron da Alexandria sobre pneumática e hidráulica (que já haviam sido empregados no século II a.C. para propósitos humorísticos), os construtores renascentistas começaram a construir vários autômatos. As aplicações de Heron foram coisas como abrir automaticamente portas de templos e pássaros artificiais que cantavam através de apitos de vapor. Nas construções renascentistas, os autômatos se tornaram mais complexos, particularmente nos sistemas de fontes:

O jardim de águas da Villa d'Este, construído em 1550 em Tivoli, nas cercanias de Roma, para o filho de Lucrécia Borgia (é o mais conhecido). O declive da colina foi usado para suprir fontes e dezenas de grutas em que imagens motorizadas-pela-água se movem, jorram e encenam... O Chateau Merveilleux de Hellbrunn... é cheio de imagens de homens e mulheres os quais as fontes ligam e desligam inesperadamente ou, 
operando no intrincando e muito surpreendente teatro de fantoches, movidos pelo poder da água. ${ }^{5}$

O alcance para os autômatos foi posteriormente desenvolvido num número de direções que vão desde máquinas musicais, das quais o Deutsches Museum em Munique tem uma grande coleção, ao pato automatizado de Vaucanson que grasna, come, bebe e excreta. ${ }^{6}$ Muito depois, técnicas de automação foram usadas em contextos mais práticos, embora versões de teares parcialmente automatizados para a confecção têxtil começaram a aparecer no século XVIII (Vaucanson, o fabricante do pato automatizado, inventou o cilindro furado que precedeu o sistema de cartão perfurado do tear de Jacquard).

Nem o relógio pode ser excluído deste vislumbro sobre a fascinação pelos autômatos. Os movimentos dos céus, da marcha da vida e morte e as figuras animadas nos relógios europeus foram outros objetos de fascinação que parecem mover-se "autonomamente". Os aspectos superficiais da automação, o semblante do animado e da similitude do humano e do animal permanecem o foco para os questionamentos ainda mais sérios com os autômatos. O que é mais "parecido" conosco parece ser o centro da fascinação e fazer da alteridade mais quase animada.

A fascinação pode esconder o que é redutivo nas seletividades tecnológicas. Mas ela também pode esconder, duplamente, uma segunda dimensão da intencionalidade instrumental, sua possível direção dissimilar, a qual pode frequentemente provar, em longo prazo, a trajetória mais interessante de desenvolvimento. Ainda que a semelhança usualmente aparente estar no primeiro plano.

Foi esta semelhança que começou a ser uma preocupação para a filosofia moderna (séculos XVII e XVIII). A famosa dúvida de Descartes também utiliza da inclinação popular pelos autômatos. Procurando provar que é a mente sozinha e não os olhos que conhecem as coisas, ele argumenta:

Donde desejaria quase concluir que se conhece a cera pela visão dos olhos e não pela tão-só inspeção do espírito, se por acaso não olhasse pela janela homens que passam pela rua, à visa dos quais não deixo de dizer que vejo homens da mesma maneira que digo que vejo a cera; e,

5 Burke, 1978, p. 106

6 Ibid., p. 107. 
entretanto, que vejo desta janela, senão chapéus e casacos que podem cobrir espectros ou homens fictícios que se movem apenas por molas?.?

Este argumento eu posso ser enganado por um robô inteligentemente concebido tem uma história excessivamente longa, mesmo junto aos precintos, faz filosofias analíticas contemporâneas.

Se Descartes fosse um contemporâneo dos atuais desenvolvimentos nas tentativas de imitação dos movimentos animais e humanos por autômatos, ele talvez repensasse sua ilustração. Não só autômatos movidos por mola, mas também os autômatos computadorizados mais sofisticados parecem mecânicos. Estes autômatos computadorizados mais sofisticados têm dificuldades de manobrar da forma como os seres vivos movimentam-se. Tal como Dreyfus apontou e como seria confirmado por muitas correntes de pesquisa, movimento corporal é talvez mais difícil de imitar do que certas atividades "mentais", como as de cálculo.

Seguir apenas a inclinação em direção à similitude, no entanto, é reduzir o que pode ser aprendido de nossas relações com as tecnologias. O corrente estado da arte nas pesquisas em Inteligência Artificial, por exemplo, enquanto sendo parcialmente libertadas de seu estado fundamentalístico inicial, continua primariamente dentro da meta de criar similaridades com a inteligência humana ou modelar o que se acredita serem analogias à nossa inteligência. Ainda que possa bem ser que as diferenças que emergem da experimentação computadorizada possa ser mais informativa ou, ao menos, tão informativa como as similitudes.

Existem o que eu devo chamar de intencionalidades tecnológicas que emergem a partir de várias tecnologias. Vamos nos engajar numa pseudocartesiana, construção imaginativa de um robô humanoide, junto aos limites das tecnologias facilmente combináveis e disponíveis, com o intuito de notar as estruturas de similaridade/diferença que podem ser apresentadas. Eu devo começar com as tecnologias de "percepções" dos equipamentos sensoriais: E se o robô tivesse que ouvir? O inventor, talvez limitado por um orçamento humanista, pudesse instalar um microfone omnidirecional por orelhas. Nós podemos dar uma olhada no que nosso robô poderia "ouvir" ao adicionar uma fita cassete para servir como uma "memória" gravada de sua "audição". O que é ouvido poderia mostrar-se como sendo estruturado muito diferentemente, como uma forma muito diferenciada da intencionalidade daquilo que qualquer ouvinte humano poderia escutar.

7 DESCARTES, René. Meditações Metafísicas, Segunda Meditação, \$14. São Paulo: Nova Cultural, 1991. 
Assumindo que nosso robô frequenta uma aula universitária numa grande sala e está sentado, tal como um estudante tímido poderia estar, próximo ao fundo. Dados os limites da tecnologia mencionada, o que seria ouvido falharia no aspecto de possuir o padrão de primeiro plano/segundo plano da audição humana ou da eliminação seletiva do ruído que até audições ordinárias apresentam. A memória auditiva do robô, recuperada, revelaria algo muito mais como um mundo auditivo de dados sensoriais ao invés do mundo ao qual estamos acostumados. A voz do professor ou professora, assim gravada e junto aos baixos limites talvez detectáveis, seria constantemente abafada sob os ruídos e sons de fundo que são seletivamente disfarçados pela audição humana. Para outros propósitos, precisamente esta intencionalidade tecnológica diferentemente estruturada pode bem ser útil e informativa. Tal seletividade auditiva diferente pode, talvez, oferecer pistas deste amortecimento arquitetural dos sons precisamente porque o que é reprimido na audição humana se destaca. Em suma, existe "verdade" a ser encontrada igualmente na similaridade e na diferença que as intencionalidades tecnológicas revelam.

Um efeito similar pode ser notado no que diz respeito à visão do robô. Fossem seus olhos feitos com equipamentos de televisão e a memória para gravar o que foi visto mostrada numa tela, nós notaríamos, novamente, a planicidade de seu campo visual. $\mathrm{O}$ fenômeno da profundidade seria enormemente reduzido ou até desapareceria. Embora nós tenhamos nos acostumado com este campo plano ao assistir televisão, é fácil voltar a ficar consciente sobre a falta de profundidade entre o arremessador e o rebater no jogo de beisebol mostrado na tela. A forma tecnológica da intencionalidade difere significativamente de seu correspondente humano.

A fascinação com a similitude humana ou animada junto ao reino das relações de alteridade é já outra instância dos tipos de fascinação permeando nossas relações com tecnologias. O deslumbramento de Galileu com aquilo que ele viu através do telescópio, foi, com efeito, a localização da similitude junto ao uso incorporado. A ampliação foi a ampliação da capacidade visual humana e permaneceu junto ao alcance do que era familiarmente visível. A trajetória horizontal da ampliação que pode mais e mais ampliar a visão é a trajetória junto a uma práxis já familiar.

Com os exemplos de fascinação com os autômatos, a fascinação também permanece junto ao reino do que é familiar, agora numa forma de fenômeno espelho para humanos e a tecnologia. De todos os animais no reino da terra, 
parece que os humanos são aqueles que podem prolongar esta fascinação mais intensamente. Paul Levinson, numa análise da história das tecnologias midiáticas, argumentou que existem três estágios pelos quais cada tecnologia passa. O primeiro é o da tecnologia como um brinquedo ou novidade. A história da tecnologia do filme é instrutiva:

Os primeiros criadores de filmes não foram artistas mas pensadores... A meta deles ao fazer um filme não era a de criar beleza, mas a de demonstrar uma curiosidade científica. Uma pesquisa sobre os primeiros “diálogos" como em $O$ Cantor de Jazz, primeiros esforços em animação tais como os desenhos Laugh-O-Gram da Disney, e de fato a suposta estreia do filme cinematográfico em Fred Ott's Sneeze dão suporte [a esta tese] por si próprios. ${ }^{8}$

A mesma observação pode ser feita sobre muitas invenções. Mas uma vez que tomadas mais seriamente, novidades podem ser transformadas num segundo estágio, de acordo com Levinson: aquele da tecnologia como sendo um espelho da realidade. Isto também ocorre na história do filme. Seguindo as curiosidades iniciais do início da indústria do filme, a introdução da apresentação dos Lumieres das "atualidades" foi fascinante, em parte, precisamente pelas seletividades ampliação/redução que as tecnologias do filme produziram por meio de intencionalidades de filme únicas. Exemplos podem ser tão mundanos quanto "trabalhadores deixando a fábrica, a refeição de um bebê e o famoso trem adentrando a estação.” O que fez de tais verdades cinematográficas tão dramáticas foram "neste caso, um trem real se dirigindo para uma estação real, sob um ângulo tal, que a audiência podia quase acreditar que o trem estava indo em direção a eles". ${ }^{\prime}$

Este espelho da vida, como a automação, não é isomórfico junto experiência não 'tecnológica, mas é transformado tecnologicamente junto aos vários efeitos que exageram ou aumentam tais efeitos enquanto, simultaneamente, reduzem outros. Levinson é bastante explícito em sua análise acerca das formas que as tecnologias recém-introduzidas também ampliaram este desenvolvimento:

O crescimento dos filmes, de artifícios a replicadores, foi aparentemente em grande parte dependente de novos componentes tecnológicos... O filme de "brinquedo" exibido para indivíduos que espiavam junto a cinetoscópios individuais; mas a "realidade" do filme alcançou as

8 LEVINSON, Paul. “Toy, Mirror and Art: The Metamorphosis of Technological Culture," in Philosophy, Technology and Human Affairs, ed. Larry Hickman. College Station: Ibis Press, 1985, p. 163.

9 Ibid., p. 165. 
audiências das massas, que assistiam a realidade-substituta em grupos nos teatros. A conexão entre as massas e a realidade simulada, frequentemente, não foi acidental. Diferente da percepção das novidades, que é inerentemente subjetiva e individualizada, a percepção da realidade é fundamentalmente objetiva, processo de grupo. ${ }^{10}$

Embora a progressão da análise aqui se mova das relações hermenêuticas e de incorporação para as de alteridade, a interjeição dos exemplos de filme ou cinema é de sugestivo interesse. Tais tecnologias são transicionais entre fenômenos hermenêuticos e de alteridade. Quando eu primeiro introduzi a noção de relações hermenêuticas, empreguei o que pode ser chamado de tecnologia "estática": escrita. As longas e agora antigas tecnologias de escrita resultaram em textos fixos (livros, manuscritos, etc., todos eles, evitando-se a decadência ou destruição, se mantêm estáveis em si mesmos). Com o filme, o "texto" permanece fixado apenas no sentido de que se pode repetir, tal como um texto escrito, a visão e audição do texto cinematográfico. Mas o modo de apresentação é dramaticamente diferente. Os "caracteres" são agora animados e teatrais, diferentemente dos caracteres fixos do alfabeto ou do texto escrito. O "mundo" dinâmico do texto-cinema, enquanto retém muitos dos aspectos funcionais da escrita, também agora captura o semblante do tempo real, ação, etc. Ele continua algo para ser "lido" (visto e ouvido), mas o objeto correlato necessariamente parece mais "vívido" do que seu texto escrito análogo. Este fato, ingenuamente vivenciado pelas atuais gerações de viciados em televisão, é indubitavelmente um aspecto nos problemas que emergem entre o hábito de assistir televisão o estado das habilidades de leitura. James Burke apontou que "a maioria das pessoas nas nações industrializadas avançadas gastam mais tempo assistindo televisão do que fazendo qualquer outra coisa fora o trabalho." ${ }^{11} \mathrm{O}$ mesmo balanço de utilização do tempo também se apresentou em entrevistas junto a estudantes. As horas gastas assistindo televisão entre estudos universitários, nacionalmente, são iguais ou excedem àquelas despendidas para fazer tarefa ou preparação extraclasse.

Filme, cinema ou televisão podem, em suas dimensões hermenêuticas, referir-se de modo único ao "mundo". A forte resposta negativa à Guerra do Vietnã foi claramente devida, em parte, à virtualmente inevitável "presença" da guerra 
na sala de estar de virtualmente todo mundo. Mas filmes, como tecnologias legíveis, são também apresentações, o terminus focal da situação perceptiva. No sentido emergente, eles são as formas mais dramáticas de urgência perceptual nas quais o apresentado teve suas próprias características conferindo a quase alteridade. Ainda que o engajamento com o filme normalmente continue a ser uma forma de engajamento com o outro. Mesmo com a raiva que surja a partir de um ultraje sobre atrocidades civis ou o pathos vivenciado em assistir epidemias de fome na África, as emoções não direcionadas para o monitor, mas, indiretamente, através dele, em formas mais apropriadas de ações políticas ou de caridade. Nesta extensão há contida uma referência hermenêutica para onde quer que seja em vez de para o instrumento tecnológico. Sua quase alteridade, a qual também está presente, não é totalmente focal no caso de tais tecnologias de mídia.

Um exemplo de colapso de alta tecnologia, no entanto, fornece ainda outra sugestão para a emergência do fenômeno de alteridade. Processadores de palavras tem se tornado tecnologias familiares, frequentemente fortemente apreciados por seus usuários (incluindo muitos filósofos que afetuosamente defendem suas escolhas, professando conhecimento sobre as habilidades relativas de suas máquinas e programas, etc.). Ainda no colapso, este relacionamento quase amoroso revela, também, seu quase ódio no lado oposto. Qualquer forma de "pane" pode ocorrer, particularmente se alguma razoavelmente ampla seção do texto estiver envolvida, ela ocasiona frustração e até mesmo raiva. Então, também, os programas possuem suas idiossincrasias, que permitem ou não permitem certos movimentos; e outra forma de competição humano-tecnologia pode emergir. (Dominar, no mais alto sentido, provavelmente vem de aprender a programar e assim oprimir a inteligência prévia da máquina. "Hackear"torna-se a competição tipo-jogo na qual todo um sistema é a alteridade correlata.) Relações de alteridade podem ser notadas emergindo num amplo domínio das tecnologias de computação que, enquanto falhando seriamente em imitar as encarnações corporais, mesmo assim apresentam a quase alteridade junto aos limites da linguística e, mais particularmente, dos comportamentos lógicos. Ultimamente, é claro, em qualquer disputa que apareça, suas fontes repousam opacamente também junto a outros humanos, mas também junto ao tecnofato transformado, que agora desempenha em si um papel mais óbvio junto à rede relacional global.

Eu tenho sugerido que o computador é um dos mais fortes exemplos de tecnologia que pode ser posicionado junto às relações de alteridade. Mas sua alteridade continua uma quase alteridade, e sua utilidade genuína continua 
pertencendo às bordas de suas capacidades hermenêuticas. Ainda a despeito disso, a tendência a fantasiar sua quase alteridade em uma alteridade autêntica é difusa. Romantizações, tal como as imagens do emotivo e falante "Hal" do filme 2001: Uma Odisseia no Espaço, logo teme que o "poder cerebral" dos computadores possam em breve substituir o pensamento humano, temores de que decisões políticas ou militares não vão apenas ser informadas por, mas também tomadas por computadores, são todos sintomas que revolvem em torno do posicionamento de alteridade para a tecnologia.

Essas romantizações são correspondentes da alteridade com os já previamente notados sonhos que anseiam pela incorporação total. Fosse o tecnofato genuinamente um outro, ele poderia, ou não, ser tecnológico. Mas mesmo como um quase outro, a tecnologia fica aquém de tal totalização. Ela retém seu papel único no continuum das relações humano-tecnologia como sendo o mediador da transformação, mas como um mediador reconhecível.

$\mathrm{O}$ anseio pela realização do desejo ocasionado pelas relações de incorporação, o desejo pela transparência tecnológica total que ainda significaria eu, ao mesmo tempo em que me são ofertados os poderes que o uso da tecnologia disponibiliza, tem aqui sua fantasia opositora, e esta nova fantasia possui a mesma contradição interna: ela reduz ou, neste caso, extrapola a tecnologia naquilo que não é uma tecnologia (no primeiro caso, as transformações mágicas estão em mim; neste caso, junto ao outro), e, ao mesmo tempo, deseja o que não é idêntico a mim ou ao outro. A fantasia serve para efeitos transformacionais. Ambas as fantasias, com efeito, negam que tecnologias desempenhem os papéis que elas exercem no continuum humano-tecnologia das relações; ainda que seja apenas sobre a condição de que haja alguma diferenciação detectável junto à relatividade que são as formas únicas nas quais as tecnologias transformam a experiência humana que possam surgir.

A despeito da tentação em aceitar a fantasia, o que a quase alteridade das relações de alteridade faz, demonstra que humanos podem se relacionar positivamente ou presencialmente junto às tecnologias. Com respeito a isto e neste nível, tecnologias emergem como entidades focais que podem receber múltiplas atenções humanas, dado as diferentes formas do outro. Por esta razão, uma terceira formalização pode ser empregada para distinguir este conjunto de relações:

$$
\text { eu-tecnologia-(-mundo) }
$$


Eu coloquei os parênteses justamente para indicar que nas relações de alteridade pode existir, mas não precisa existir, uma relação através da tecnologia para o mundo (embora possa ser bem esperado que a utilidade de qualquer tecnologia irá, necessariamente, ocasionar apenas como uma referencialidade). O mundo, neste caso, pode continuar contexto ou segundo plano, e a tecnologia pode emergir em primeiro plano e quase outro focal com o momentaneamente eu me engajar.

Esta separação da tecnologia de seu contexto de uso ordinário é também o que possibilita que a tecnologia recaia nos vários engajamentos desengajados que constituem tais atividades tal como jogos, arte ou esportes.

O primeiro itinerário fenomenológico ao longo das focais e diretas relações humano-tecnologia podem agora ser considerados completos. Eu tenho argumentado que os três conjuntos de relações distinguíveis ocupam um continuum. Em um extremo estão aquelas relações que aproximam as tecnologias ao quase $e u$ (relações de incorporação). Aquelas tecnologias que eu posso tomar junto a minha experiência, as quais através de suas semitransparências permitem que o mundo possa ser feito imediato e, assim, entram junto à relação existencial que constitui meu self. No outro extremo do continuum estão as relações de alteridade nas quais a tecnologia se torna quase outro, ou tecnologia "como" outro às quais eu me relaciono. Entra elas repousa a relação com tecnologias que tanto media quanto ainda assim complementa minha percepção e relação corporal com as tecnologias, as relações hermenêuticas. As variantes podem ser assim formalizadas:

Relações Humano-tecnologia-Mundo

Variante 1, Relações de Incorporação

(Humano-tecnologia) $\rightarrow$ Mundo

Variante 2, Relações Hermenêuticas

Humano $\rightarrow$ (tecnologia-Mundo)

Variante 3, Relações de Alteridade

Humano $\rightarrow$ tecnologia-(-Mundo) 
Embora eu tenha caracterizado os três tipos de relações humano-tecnologia como pertencentes ao continuum, existe ainda o sentido no qual os elementos junto a cada tipo de relação são diferentemente distribuídos.

Existe uma razão entre a objetividade da tecnologia e sua transparência no uso. No extremo apogeu da incorporação, uma presença de fundo da tecnologia pode ainda ser detectada. Similarmente, mas com uma razão diferente, uma vez que a tecnologia tem emergido como um quase outro, sua alteridade continua junto ao domínio da invenção humana por meio da qual o mundo é alcançado. Junto a todos os tipos de relações, a tecnologia se mantém artifactual, mas é também sua própria formação artifactual que permite as transformações que afetam a terra e a nós mesmos.

Todas as relações examinadas até agora têm sido também relações focais. Isto é, cada uma das formas de ação que ocorrem por meio destas relações tem sido marcada por uma autoconsciência implicada. Os engajamentos através, com e para as tecnologias ficam junto ao estrito núcleo da práxis. Tal ênfase, enquanto necessária, não esgota o papel das tecnologias nem de suas experiências. Se as atividades focais são centrais e em primeiro plano, há também fenômenos secundários e em segundo plano que não são menos neutros do que aqueles no primeiro plano. É por esta razão que uma incursão final nesta fenomenologia da técnica precisa ser empreendida. Tal incursão precisa ser um exame das tecnologias de segundo plano e junto aos horizontes das relações humano-tecnologia.

\section{Relações de segundo plano}

Com as relações de plano de fundo, esta inspeção fenomenológica sofre uma virada, em vez de atender-se as tecnologias em primeiro plano para focar-se naquelas que permanecem em segundo plano ou se tornam um tipo de ambiente tecnológico próximo em si. É claro, existem tecnologias descartadas ou fora de uso, que em um senso extremo ocupam a posição de segundo plano na experiência do lixo humano. Destas, algumas podem ser recuperadas junto aos não usos, mas focais contextos, tais como nos museus tecnológicos ou nas transformações em arte do lixo (junk art). Mas a análise aqui aponta para tecnologias especificamente em funcionamento que ordinariamente ocupam as posições ou campo de fundo.

Primeiro, vamos atender para certas tecnologias individuais desenvolvidas para operar máquinas de segundo plano automáticas e semiautomáticas, que 
são tão universais hoje que são boas candidatas para esta análise. No contexto mundano do lar, sistemas de iluminação, aquecimento e resfriamento e todo o conjunto de equipamentos semiautomáticos são bons exemplos. Em cada caso, há alguma necessidade para um instante de intrusão deística ao programa ou colocar a maquinaria em movimento ou em sua tarefa. Eu ajusto o termostato; então, se a maquinaria for de alta tecnologia, o sistema aquecedor/resfriador vai operar independentemente de uma ação contínua. Ele pode empregar mudanças de tempo-temperatura, sensores externos para ajustar-se ao clima em variação, e outras operações cibernéticas. (Enquanto isso possa funcionar bem no contexto do lar, eu permaneço entretido no estado ainda primitivo de arte no complexo acadêmico que eu ocupo. Leva cerca de dois dias para o sistema ajustar-se às súbitas mudanças climáticas do outono e primavera, fazendo assim do escritório, que na verdade possui janelas que podem ficar abertas, uma raridade altamente desejável.) Uma vez operando, a tecnologia funciona como uma presença de fundo dificilmente detectável; por exemplo, na forma de barulho de fundo, tal como quando o aquecedor aciona. Em operação, porém, a tecnologia não chama nenhuma atenção focal.

Note duas coisas sobre esta relação humano-tecnologia: a atividade da máquina no papel da presença no segundo plano não é apresentada como o que eu denominei de transparência e nem de opacidade. O "afastamento" desta função tecnológica é fenomenologicamente distinto como um tipo de "ausência". A tecnologia está, por assim dizer, "posta de lado". Ainda que como uma ausência presente, ela mesmo assim se torna parte do campo vivenciado do habitante, um pedaço do ambiente imediato.

De alguma forma mais elevada sobre a escala das tecnologias semiautomáticas estão os aparelhos que demandam por explícitas e repetidas intervenções deísticas. A máquina de lavar, secar, micro-ondas, torradeira, etc., todos demandam por programação repetida e então pelo trato com os produtos processados (roupa, comida, etc.). Ainda assim, como nos sistemas automatizados, as máquinas semiautomáticas permanecem no segundo plano enquanto em funcionamento.

Em ambos os sistemas e equipamento, no entanto, pode-se detectar pistas para as formas nas quais as relações de segundo plano compõe a textura do ambiente imediato. No lar elétrico, existe virtualmente um constante zumbido de um tipo ou de outro, que é parte da textura tecnológica. Ordinariamente, este "barulho branco" pode passar despercebido, embora eu esteja sempre tranquilo 
de que ele permanece parte de uma consciência de borda, tal como quando hóspedes visitam minha casa na montanha em Vermont. O comentário inevitável é sobre o silêncio da floresta. De uma só vez, a ausência de ruídos de segundo plano torna-se notável.

Texturização tecnológica é, por certo, muito mais profunda que a camada de ruído no segundo plano que sinaliza sua ausência presente. Antes de voltar-se para futuras implicações, uma tentação que poderia ocorrer através da seleção muito estreita dos exemplos contemporâneos precisa ser evitada. Pode-se pensar que apenas, ou predominantemente, o mundo contemporâneo da alta tecnologia utiliza e vivencia tecnologias de segundo plano. Isto não é o caso, mesmo no que diz respeito às tecnologias automáticas ou semiautomáticas.

O espantalho é um dispositivo antigo "automatizado". Seu mimetismo de um humano, com roupas tremulando ao vento, é um espantador de corvos específica e automaticamente desenvolvido, criado para operar na ausência dos humanos. De modo similar, no Japão antigo existiam espantadores de cervos automáticos, feitos com tubos de bambu, girando em espiral e colocados de forma que uma queda d'água ou corrente de ar pudesse vagamente preencher os tubos. Quando ele estava cheio o suficiente, o dispositivo se movimentaria e sua outra extremidade bateria em um tambor produzindo um som; o barulho espantava para longe qualquer cervo e os afastava da pilhagem. Nós já notamos o papel que a automatização desempenha nos rituais religiosos (rodas de oração e representações de adoração concebidas para funcionar continuamente).

Interpretados tecnologicamente, existem alguns exemplos bem-humorados de "automação" que podem ser encontrados nas antigas práxis religiosas. $\mathrm{O}$ moinho de vento orador hindu "automaticamente" envia suas preces quando o vento sopra; e nos antigos templos sumérios havia ídolos com grandes olhos nos altares (os deuses), e na frente deles existiam estátuas menores, com olhos grandes, que representavam adoradores humanos. (Seu equivalente contemporâneo pode ser a piada na qual o professor ou a professora deixa a sua aula gravada numa fita para a classe, a qual os estudantes também podem "automaticamente” ouvir, ao deixar seus próprios gravadores para gravar a gravação do mestre).

Enquanto nós não conceituamos frequentemente tais dispositivos antigos desta forma, parte do propósito de uma análise existencial é precisamente levar em conta a identidade ou função e a "antiguidade" de todas estas relações existenciais. Isto não é de forma alguma negar as diferenças de contexto ou variações 
de grau de complexidade presentes nas versões de automação contemporâneas, quando comparadas às antigas.

Outra forma de relação de segundo plano é associada com as várias modalidades de tecnologias que servem para isolar humanos de um ambiente externo. Vestuário é um caso limite. Roupas claramente isolam nossos corpos da temperatura, vento e outros fenômenos extremos do clima que poderiam tornar-se perigosos para a vida; mas o vestuário vivenciado é um caso limite com as relações de incorporação, pelo que nós, de fato, sentimos o ambiente externo através das roupas, ainda que de um modo particularmente atenuado. As roupas não são desenvolvidas, na maioria dos casos, para serem "transparentes" do mesmo modo que os exemplos instrumentais anteriores eram. Antes disto, porém, são feitas para possuir certa opacidade, sem restringir o movimento. Ainda que as roupas sejam parte de uma consciência de borda na maioria de nossas atividades diárias (Eu não estou aqui, obviamente, me dirigindo a aspectos da roupa enquanto moda).

Um exemplo melhor de uma relação de segundo plano são as tecnologias de abrigo. Embora abrigos possam sem encontrados (cavernas) e assim participar inalterados da práxis humana, a maioria deles é construída, tal como é a maioria dos artefatos tecnológicos; mas uma vez construídos e seja como forem designados para isolar ou tendo em vista o clima externo, eles se tornam mais que fenômeno do campo do segundo plano. Aqui, novamente, as culturas humanas apresentam um continuum fantástico do minimalismo às estratégias maximalistas no que diz respeito a esta versão de quase segundo plano.

Muitas culturas tradicionais, particularmente nas áreas do Hemisfério Sul, praticam uma tecnologia de abrigos abertos, possivelmente com um teto primário para proteger da chuva e do sol. Tais pessoas frequentemente consideram desagradáveis tais itens como janelas e particularmente janelas de vidros. Eles não desejam ser isolados dos elementos. No outro extremo estão as estratégias maximalistas, com os desejos mais extremos para converter as tecnologias de abrigo num sistema virtual de suporte à vida, autônomo e isolado. Eu devo chamar isto de casulo tecnológico.

Um exemplo contemporâneo de um quase casulo são os submarinos nucleares. Sua tripulação vive no interior, e a embarcação é desenvolvida para manter-se no mar por períodos prolongados, mesmo submersa por longos períodos de tempo. 
Existem sofisticados sistemas para reciclagem de resíduos, água e ar. O contato com o mundo exterior, obviamente importante neste caso, se dá inicialmente através de monitoramento por dispositivos hermenêuticos igualmente sofisticados (sonar, rádio de baixa frequência, etc.). Todas as tarefas ordinárias acontecem no interior do casulo. Uma projeção multibilionária para um abrigo-casulo num grau muito mais elevado é a estação espacial para vida em longo termo, agora em debate.

Parte do propósito central de uma estação espacial é o de vivenciar ao criar-se um miniambiente, ou "terra" artificial, que poderia ser totalmente tecnologicamente mediada. Ainda que as casas high-tech suburbanas contemporâneas apresentem aspectos similares. Totalmente automatizadas para a temperatura e umidade, estruturas comprimidas para o ar, algumas com vidros que se ajustam à luminosidade, todos esses lares partilham da mesma trajetória de autocontenção. Mas enquanto estas ilustrações são unicamente texturizadas com alta tecnologia, restam ainda, tal como antes, exemplos diferentemente contextualizados mas similares no passado.

Espaços totalmente isolados frequentemente têm sido associados aos rituais e práxis religiosa. A kiva das passadas culturas nativas do Sudoeste americano era cavada fundo no solo, sem janela e ficava virtualmente selada. Era o espaço para importantes iniciações e sociedades secretas, que se reuniam em tais casulos antigos para seus próprios propósitos. O recinto evidencia diferentes tipos de totalização.

O que é comum para todo o grupo de exemplos apontados até aqui é a posição ocupada por tais tecnologias, posição de segundo plano, a posição de uma ausência presente com sendo uma parte, ou um campo total, de tecnologias imediatas.

Em cada um dos exemplos, o papel de segundo plano é um papel de campo, não usualmente ocupando uma atenção focal, mas mesmo assim condicionando o contexto no qual seus habitantes vivem. Existem, é claro, grandes diferenças a serem detalhadas em termos dos tipos de contextos em que tais tecnologias de segundo plano operam. Colapso, novamente, pode desempenhar um papel indicativo significativo para demonstrar tais diferenças.

As implicações envolvidas da sociedade contemporânea high-tech são muito complexas e frequentemente tão interligadas tal que caem em grande perturbação quando a tecnologia em segundo plano falha. Em 1985, Long Island foi assolada pelo Furacão Glória, resultando em massiva destruição das linhas de 
energia. A maioria das áreas ficou sem energia elétrica por, pelo menos, uma semana, e, em alguns casos, duas. A eletricidade teve que ser substituída por tecnologias antigas (lanternas, velas, lampiões de querosene), e os suprimentos para cada um deles se tornaram escassos imediatamente. Minha suspeita é de que se olhar para as estatísticas de nascimentos no tempo apropriado depois desta mudança radical nos hábitos noturnos, se revelarão os mesmos saltos que de fato ocorreram durante os blecautes dos primeiros anos em New York.

De modo similar, com a falha da refrigeração, os hábitos alimentares têm de mudar temporariamente. $\mathrm{O}$ exemplo pode ser expandido indefinidamente; a compra em massa de grandes geradores por compradores universais manteve uma companhia de Minnesota em produção plena por vários meses depois, no intuito de estarem preparados para a "próxima vez". Em contraste, enquanto os mesmos efeitos a curto prazo eram sentidos durante os constantes blecautes de 1985, eu estava em Vermont na minha casa de veraneio, que é iluminada por lâmpadas de querosene e até refrigerada por um refrigerador a querosene. E estava simplesmente alheio aos massivos distúrbios até que o Sunday Times chegasse. Aqui está uma diferença entre um sistema antigo, fora da malha e um contemporâneo, em rede.

Apesar de sua posição como relações de campo ou de segundo plano, tecnologias aqui apresentam muitas das mesmas características transformacionais encontradas nas relações prévias explicitamente focais. Diferentes tecnologias estruturam ambientes diferentemente. Eles exibem formas únicas de não neutralidade por meio de formas diferentes nas quais elas estão interligadas com o mundo da vida humano. Tecnologias de segundo plano, não menos que as tecnologias focais, transformam as formas da experiência humana e, precisamente porque elas são ausências presentes, podem exercer efeitos mais sutis indiretos sobre a forma como o mundo é vivenciado. Também existem envolvimentos com círculos amplos de conexão e seletividades de ampliação/redução que podem ser descobertas nos papéis das relações de plano de fundo; e, finalmente, as variedades de estratégias, das minimalistas às maximalistas, continuam tão abertas a esta dimensão das relações humano-tecnologia como cada uma das outras.

\section{E. Fenômeno horizontal}

Os limites desta primeira análise estão agora ao alcance da mão. Com os aspectos de campo e indiretos das relações de segundo plano, também se indica 
o fenômeno horizontal, que marca as fronteiras da fenomenologia. (Deve-se notar que o termo "horizonte" na fenomenologia é um conceito-limite. Diferentemente da expressão comum "expandir os horizontes", tal possibilidade não existe aqui. O horizonte é o limite além do qual a investigação cessa de apresentar suas características internas e, como uma viagem pelo mar, o horizonte sempre permanece aquela fronteira distante entre o céu e o mar ou terra e mar. Ele nunca fica mais próximo.)

Horizontes, no entanto, podem ser indicados num número de formas no que diz respeito ao extremo fenômeno de borda. Eles são de um uso importante e indicativo aqui, sendo que tal menção deve ser feita ante de se mover para o segundo programa. Em toda a análise precedente, a experiência da tecnologia sempre foi tal que existia alguma diferença experiencial recorrente entre o que é vivido e o vivente. Todas as transparências têm sido notadas como sendo quase transparências, todas as alteridades como quase alteridade, e até mesmo as ausências presentes dos fenômenos de segundo plano são pelo menos indiretamente recuperáveis.

Tal posicionamento das tecnologias como pertencentes a um continuum de relações, que aponta para propriedades artefactuais essenciais junto à práxis humana, tem sido um constante achado em todas as variações. Ainda que a questão das extremidades, além do que não tem recuperação, onde talvez as tecnologias deixem de serem tecnologias, continua intrigante. Eu devo tentar localizar tal fenômeno junto ao espectro das fenomenologias explícitas que eu tenho seguido.

No caso das relações de incorporação, existem incorporações que caem "abaixo" de recuperação? Tecnologias de incorporação são tomadas junto às experiências pessoais, mas permanecem distintivas, ao menos na borda ou eco fenômeno, como outra que não eu mesmo. Mas o que dizer sobre o desejo secreto de ter a tecnologia se tornando eu? Tais desejos são aproximados nas trajetórias biônicas das tecnologias contemporâneas. Um exemplo de fronteira é o dente obturado. Embora haja pouca dúvida de que algo está sendo "adicionado" à minha boca durante o procedimento dental e há um período de acomodação no qual vivencio a estranheza da cobertura, depois de um tempo o dente se torna quase que totalmenteincorporado. Mesmo ainda aqui, permanece uma consciência menos distinta recuperável da diferença na textura, a sensação de quente ou frio, e o fato de o dente ficar mais escorregadio, aspecto que demanda por gomas de mascar especiais que não ficaram grudadas. Mas a artifactualidade 
da cobertura é, de fato, um extremo de recorrer como sendo uma relação. Ela se aproxima de "ser eu".

São menos os implantes que, segundo reportam os usuários, são vivenciados como sendo um diferente modo de ser o seu próprio corpo. Articulações do quadril de aço inoxidável e teflon permitem ao previamente debilitado caminhante a recuperar a caminhada próxima do normal, mas as diferenças discerníveis permanecem uma consciência de borda do indivíduo bionicamente transformado. Ainda que tais implantes protéticos possibilitem um "ser junto ao mundo" como sendo um ser corporalmente modificado.

Tais transplantes mecânicos ainda não alcançaram a extremidade do fenômeno horizontal. Um ainda mais extremo conjunto de exemplos emerge das transformações químicas, o que eu devo chamar de tecnologias ingeríveis. A história das pílulas de controle de natalidade é instrutiva neste caso. As primeiras usuárias das pílulas reportaram dois resultados: elas de fato sentiram mudanças no corpo, naquele período dores foram sentidas de forma diferente; e algumas vezes houve outros efeitos colaterais, tais como uma pequena náusea. Mas tal como na fascinação com as transformações de ampliação previamente notadas de todas as novas tecnologias, a maioria de tais efeitos colaterais foi reprimida em favor da exaltação acerca da habilidade de envolvimento em relações sexuais livre de preocupações, próximo ao"natural", livre de gravidez.

Depois, efeitos colaterais atrasados foram associados com a pílula (em alguns casos, pressão sanguínea elevada, preocupações com o câncer, etc.), mas isto podia ser no máximo indiretamente vivenciado. A pílula, uma vez ingerida, operava como uma espécie de relação de segundo plano interna do tipo mais extremo de borda. Como ocorre com todas as tecnologias ingeríveis, o "eu sou aquilo que eu como" é um fenômeno que coloca a maioria dos efeitos à distância ou eles ocorrem com certo atraso.

Este caso específico, no entanto, é instrutivo de um modo diferente. As tecnologias ingeríveis são tecnologias no final das contas? Elas são claramente produtos tecnológicos (da indústria química) e são claramente entidades tecnologicamente transformadas; porém, ao passo que elas são absorvidas junto ao nosso próprio corpo, elas, muito mais próximas do que nossos exemplos prévios artefactuais, são profundamente incorporadas.

Ainda mais ambiguamente, a questão da tecnologia biológica deve ser levantada neste horizonte extremo. Eu me refiro aqui não aos assuntos populares que circulam em torno de se a vida animal, por meio de manipulação genética, 
pode ser ou não patenteada, mas a reflexividade literal que agora as tecnologias biológicas podem ter sobre a transformação da vida corporal humana em si. A transformação genética apresenta os mesmos aspectos estruturais transformadores que as outras relações humano-tecnologia apresentam, mas na medida em que como resultado genético se torna o que nós somos, ela cai, pelo menos, abaixo do nível da análise contrastante existencial tomada aqui. E isto não é dizer, no entanto, que uma análise hermeneuticamente estruturada é evitada.

Com técnicas biológicas, alcançou-se uma nova fronteira entre tecnologia e vida em que os horizontes da natureza e da artificialidade são embaraçados. Ainda enquanto a habilidade em manipular material genético, mais precisamente por meio da identificação de genes particulares ou sequências (uma façanha tornada possível pela habilidade instrumental de ampliar os microníveis do ser, porém, condicionada por uma possibilidade essencial de tecnologia), tais técnicas biológicas também são antigas. A criação de plantas e animais, hibridismo e outras manipulações de produtos selvagens são tão antigos quanto a civilização e ocorrem independentemente em muitas partes do mundo.

Para além disso, o emaranhamento da fronteira dos produtos vivo/artificial é antecipado nas mudanças de postura e nos usos frente às plantas e aos animais domésticos. Elas se tornam claramente "seres de uso" sob o controle humano e para o uso humano.

Os horizontes pertencem às fronteiras do campo ambiental vivenciado. Como os "limites" do campo visual, eles situam o que é explicitamente presente, enquanto sendo um fenômeno em si mesmo, os horizontes recuam. E onde quer que nós nos refiramos a um tipo de horizonte interno (as bordas da incorporação) ou as extremidades do horizonte externo (a forma definitiva de texturização que uma cultura tecnológica específica pode tomar), o resultado é o tipo de uma "atmosfera". Isto não significa que os elementos, particularmente em termos de fenômeno social, não possam ser identificados. Por exemplo, em situações contemporâneas, um fenômeno atmosférico é o medo vago ou a ansiedade relatada com a possibilidade de uma ameaça nuclear. Este medo é sentido por crianças e por seus pais e atravessa todas as culturas industrializadas, pelo menos. Ele é parte da textura da cultura tecnológica que possui um poder ampliador destrutivo definitivo e universalizável. Mas este fenômeno do medo atmosférico social é o efeito de algo a mais: do sonho da totalização tecnológica que marca um dos aspectos maximalistas das culturas tecnológicas. 
Há um número de formas em que o medo nuclear pode ser historicamente analisado. Obviamente, a destruição do inimigo tem sido um objetivo humano tão antigo quanto a humanidade. Igualmente óbvio, nunca foi possível até o século XX atualizar este objetivo universalmente. Mas o potencial, seja instantâneo (ataque massivo entre as superpotências) ou lento (inverno nuclear), em eliminar as espécies é possível apenas para o presente e para o futuro. O problema inerente de uma solução universal totalizada é igualmente óbvio, ele é autorreflexivo e se aplica tanto para o assassino quanto para o assassinado. A necessidade política em preservar tais meios universalmente genocidas de "defesa" toma a forma das tentativas em negar a autorreflexividade. Governantes precisam encontrar meios para convencer populações de que haverá sobreviventes (o inverno nuclear será apenas um outono, etc.).

Ainda que o medo atmosférico nuclear seja o oposto do que as utopias do século anterior previam, que uma cultura tecnológica, uma vez totalizada, seria capaz de resolver todos os problemas básicos sociais tais como fome, doenças, um padrão de vida decente, um intercâmbio pacífico entre as nações. Se tais esperanças forem reduzidas ao simples sistema utópico no final do século XX, elas ainda assim jorram a partir das mesmas fontes místicas que os medos atuais.

\section{F. Eva e a espaçonave}

Talvez o que é necessário ao término deste primeiro itinerário é outra variação fictícia: imaginar a mais extrema maximização da tecnologia, a partir do outro extremo do continuum que se inicia na imaginação de um Éden não tecnológico. Esta projeção precisa primar pela cultura tecnologicamente totalizada. Os problemas de ate mesmo se imaginar tal estado de existência são paralelos àqueles encontrados junto ao sonho da inocência tecnológica no princípio, para o que devemos projetar de nossa situação presente na qual existe apenas a presunção da totalização.

Ainda que existam pistas para a trajetória da totalização precisamente a partir deste presente, aimaginação, do tipo ficção científica, deveria encontrar componentes tecnologicamente totalizados para cada dimensão da situação existencial dos seres humanos no mundo previamente inspecionado.

Para Mundo, nós teríamos que ter um "mundo" artificial, ou um ambiente autocontido, que fosse totalmente autônomo junto a algum complexo de condições tecnológicas. Embora não sejamos mais hábeis em apontar para tal "mundo" 
artificial do que nós somos capazes de encontrar algum Éden atual, o conceito de casulo tecnológico é a instância para tal trajetória. Ele é mesmo parte de nossa tradição ficcional e agora uma parte de nosso debate econômico (quantos bilhões nós estamos dispostos a gastar em tal experimento?). No presente, tal situação seria temporariamente um quarto e claramente seria altamente dependente de estações terráqueas, mas o sonho é pela totalização, ainda que as aproximações para tais minicasulos já sejam atualmente os veículos recreativos, os ambientes construídos totalmente controlados e até mesmo certos tipos de condomínios em que nós já habitamos. Isolados o máximo possível do clima (ao menos que ele seja agradável), o mundo artificial projetado é apenas uma extensão das condições presentes. Ele também é um reflexo dos desejos do presente.

Primeiramente, esta projeção, de certo modo irônica, poderia ser utilizada para esconder alguma forma de romantismo natural, uma forma que frequenta até mesmo as mais amplas fantasias espaciais de muitos filmes e séries televisivas. Ao passo que o enredo focal e os efeitos visuais são todos de espaçonaves high-tech projetadas, seres alienígenas, etc., o tema muito frequentemente é a busca por uma terra perdida ou uma nova terra. $\mathrm{O}$ romantismo também pertence aos pensamentos utópicos. Mas este não é ponto; antes, desejo destacar como até agora nós fomos bem-sucedidos em de fato construir aproximações às totalizadas, ou ao menos, maximizadas culturas tecnológicas, e o resultado é necessariamente substituir as regiões dominantes de ameaça e problemas da "natureza" para precisamente uma "cultura" tecnológica.

Nos últimos anos, a tríplice "Challenger", Bhopal e Chernobyl tornou-se quase um símbolo desta substituição do fenômeno de ameaça. Cada colapso foi sentido e assumido como um evento peculiar do final do século XX. Bhopal e Chernobyl, de longe as maiores catástrofes em termos de impacto humano, tornaram-se equivalentes aos maiores desastres naturais passados, tais como furacões ou maremotos, devastando o mundo com seus artefatos. Medos de colapsos em larga escala tornaram-se medos de sociedades tecnologicamente texturizadas.

Esses eventos, que foram notícias no mundo inteiro, são indicativos de um sutil, mas claramente substituto, ou ao menos um equivalente, das maiores ameaças de desastres naturais do passado. A mesma mistura de uma ampla e instantânea comunicação, mesmo para o interenvolvimento entre a mídia e os eventos, ocorre nos estranhos movimentos arcaicos/contemporâneos em muito do terrorismo internacional. Restauradores do fundamentalismo religioso, cujas rixas agora se espalham junto aos arsenais contemporâneos e são tornados públicos 
pela mídia contemporânea (de fitas cassetes que espalham o fundamentalismo islâmico por baixo das notícias controladas na mídia do Xá à articulação do terrorismo publicitário, à necessidade por cobertura televisa instantânea). Isso, também, é parte do processo de substituição.

Nem toda articulação, no entanto, é simbolizada pelo colapso. Junto às mesmas tragédias estava a internacionalização por atendimento médico, com experts americanos em transplantes de medula óssea ajudando pacientes soviéticos e com estrelas do rock motivando um vasto e global programa de transporte de alimentos para vítimas famintas na Etiópia. A interconexão da mídia e os eventos aqui é tão próxima quanto nos exemplos negativos anteriores.

Se o casulo tecnológico é o microcosmo para um mundo artificial no sonho de uma cultura tecnológica totalizada, seus outros componentes também recebem tratamento imaginativo. Se o casulo é o substituto para um mundo amplo, então os habitantes precisam submeter-se a um tratamento similarmente extrapolado.

Quando nós nos voltamos para exemplos das novas Evas tecnológicas que habitam nossas espaçonaves-casulos na forma de ficção científica do cinema ou televisão, elas são frequentemente híbridas ou imitações (androides ou robôs inteligentemente planejados, tal como Descartes imaginou, para serem tomados por humanos).

O ser biônico, seja mulher ou homem, é um ser concebido com novos membros tecnológicos, que diferentemente de todos os membros existentes, aprimoram a fraqueza das partes substituídas. Tais imagens de híbridos, mais potentes e mais perfeitos que os seres prévios meramente biológicos, são reflexos precisamente do sonho tecnológico previamente notado. Os seres biônicos tornaram-se uniões perfeitas de tecnologia e vida, de forma que eles simplesmente são e vivenciam a si próprios como superseres. A tecnologia deixou de ser uma tecnologia e tornou-se um (mais perfeito) humano.

Robôs e androides fictícios, no entanto, são réplicas quase perfeitas ou semblantes de humanos, embora muitos enredos eventualmente os revelem como sendo máquinas espertas cartesianas, usualmente com algum defeito oculto. Estas entidades, que neste esquema seriam ainda mais alteridades que os atuais tecnofatos, começam a revelar a parte inferior do medo que é direcionado ao objetivo do sonho em si mesmo. E se nós fossemos hábeis de fato em igualar ou exceder a nós mesmos por meio de nossas próprias invenções? Iriam nossas invenções então achar que nós não temos serventia ou, pior, deveríamos servir a elas? 
Tome a imaginação do aperfeiçoamento tecnológico numa direção diferente. E se nós fossemos tecnologicamente capazes de duplicar um ser humano, incluindo todas as fraquezas e verrugas? Não estaríamos nós na situação da máquina de leitura perfeita? Qual o sentido haveria em ser uma duplicata tecnológica perfeita de algo não tecnológico? No máximo, tal invenção satisfaria os impulsos de cópia do designer, como uma falsificação perfeita as do falsificador.

Mas se o androide fosse simultaneamente tanto humano e transformado, então ele poderia ser de interesse. E aqui as variedades ficcionais abundam: o perfeito escravo humano, ou o perfeito amante humano, ou o perfeito humano enquanto pessoa forte, etc. Ainda aqui, novamente, nós alcançamos a contradição do sonho no qual o desejo é igualmente ter e não ter uma tecnologia, com sua artifactual e seletiva essência. Nenhuma Eva humana jamais desejaria ser uma "esposa obediente"

Embora as variações fictícias mencionadas tenham sido direcionadas aos outros que possam coabitar junto ao casulo, o que foi revelado são aplicações em uma maneira similar a possíveis totalizações tecnológicas do self. Que Eva na espaçonave voluntariamente se submeteria a uma transformação tecnológica total? A resposta é, na vida contemporânea, um tanto ambígua. O uso de esteroides por atletas é aparentemente bastante comum a despeito dos riscos conhecidos (degeneração posterior dos músculos, alta pressão sanguínea, aumento do risco de paradas cardíacas). O uso de cirurgia cosmética, incluindo implantes, é elegante. Num nível muito mais antigo, os usos humanos de tudo, desde maquiagem para máscaras iniciadoras e sacrificações são transformações instrumentalmente aplicadas do corpo humano. Ainda que nenhuma destas práticas se aproxime da variação totalizada, para além dos acima provavelmente triviais propósitos, poucos Adãos ou Evas se submeteriam de bom grado a transplantes de coração, fígado ou protéticos, exceto quando a perda da vida ou de mobilidade os ameaçasse.

Que devemos parar com a falta de totalização não é em si estranho; o que é estranho é a persistência do sonho moderno cartesiano do perfeccionismo dos autômatos inteligentemente desenvolvidos como um substituto para os seres humanos.

\section{G. Sonhos de totalização}

Junto a este primeiro itinerário através das relações humano-tecnologia parece haver uma vasta anomalia. Por um lado, um exame das relações 
humano-tecnologia revela uma profunda continuidade nas formas que os humanos têm vivenciado suas tecnologias. Estas relações existenciais se aplicam igualmente para antigas e modernas, simples e complexas tecnologias. Enquanto que uma fenomenologia estrutural visa invariantes, isto é tal como deveria ser; ainda que esta ênfase sobre a igualdade deixe algo de fora particularmente no que diz respeito ao que aparece ao contemporâneo como sendo a vasta diferença entre todas as sociedade tradicionais e não industriais e nós mesmos.

Em parte, esta impressão é parte de uma tática deste primeiro programa na análise humano-tecnologia. Eu tenho tentado demonstrar que existe uma continuidade que compreende igualmente a história e as culturas humanas para além dos propósitos extravagantes daqueles que dissociariam a nós de nossos passados e de nossos pares. Ainda que desprezar a disjuntura entre as culturas maximalistas de hoje e aquelas minimalistas ou menos que minimalistas formas de vida, seria também uma distorção.

Não que sugestões sejam escassas no que diz respeito a estas diferenças. Tal tema, seguido estreitamente, mas propositadamente aqui, tem sido a ênfase sobre as disjunções que agora são possíveis por meio da instrumentação moderna. Ciência moderna, na minha visão, é distintivamente diferente de todas as ciências antigas em virtude de sua incorporação em instrumentação, sejam do tipo hermenêutico ou de incorporação, por terem feito possíveis visões do universo que tanto imaginativamente e perceptivamente excedem e se diferem de todas as cosmologias antigas. Alfred North Whitehead fez a mesma observação:

A razão para nós estarmos em um nível imaginativo mais alto não é porque nós temos uma imaginação melhor, mas porque nós temos melhores instrumentos. Na ciência, a coisa mais importante que aconteceu nos últimos quarenta anos foi o avanço no design da instrumentação. ...um instrumento fresco serve o mesmo propósito que uma viagem ao exterior; ela mostra coisas em combinações incomuns. O ganho é mais do que uma mera adição; ele é uma transformação. ${ }^{12}$

Esta transformação é a qualidade de disjunção que começa a ocorrer com o surgimento da ciência moderna, mas que foi enormemente acelerada apenas em tempos mais recentes.

Uma segunda pista para a disjunção entre tempos antigos e contemporâneos repousa nas formas como os sonhos de totalização são atualizados nas 
culturas maximalistas de hoje e nas minimalistas de ontem. De fato, humanos terem se tornado uma força geológica virtual através das tecnologias ampliadas dos tempos recentes é o assento de uma de nossas preocupações distintivas contemporâneas. Se os produtos industrializados são a maior causa do recentemente descoberto buraco na camada de ozônio na Antártida como se suspeita, se a eliminação de um número de espécies de pequenos animais ameaçados pela destruição das florestas tropicais (uma porcentagem grosseiramente equivalente em número às grandes espécies de animais extintas do passado), se a chuva ácida criando poluição ameaça as florestas nas mais altas altitudes do Hemisfério Norte, então nós temos razões para esta preocupação.

Ainda que a intensidade do impacto humano através da tecnologia no mundo atual seja claramente de uma magnitude maior que em qualquer tempo histórico, ele não é sem precedente. J. Donald Hughes, num livro notavelmente pessimista, Ecology in Ancient Civilizations, argumentou que a despeito de diferenças culturais, cada uma das civilizações circundando o Mediterrâneo produziu os mesmos resultados de (a) desmatamento, (b) pastoreio excessivo de ovelhas e cabras, e (c) erosão irreversível resultando (d) no clima árido de hoje ao longo de toda a bacia do Mediterrâneo.

Este resultado é similar quando falamos dos gregos, hebreus, romanos, fenícios ou de qualquer outro dos progenitores de nossa civilização antiga europeia. Ecologicamente falando, Hughes fornece um contraponto antirromântico à glorificação de Heidegger do templo grego:

Aqueles que olham para o Parthenon, aquele símbolo incomparável das realizações de uma civilização antiga, normalmente não enxergam sua configuração mais ampla. Atrás da Acrópole, as descobertas e secas montanhas de Ática mostram seus ossos rochosos contra o azul do céu mediterrâneo, e as ruínas do mais luxuoso templo construído pelos gregos antigos são circundadas pelas mais vastas ruínas de um meio-ambiente que eles devastaram ao mesmo tempo. ${ }^{13}$

Ainda mais antigas são as implicações dos humanos para as extinções dos grandes mamíferos do final da Era do Gelo. Ou, para voltar para um exemplo mais recente e não ocidental, extinções similares de todas as grandes aves sem asas na maioria das ilhas do Pacífico ocorreram com a expansão ao oeste dos navegadores polinésios de quem falei anteriormente. Tais resultados não são 
claramente os únicos efeitos seja de nossos ancestrais culturais ou de nossas histórias, mas repousam profundamente nas estruturas de possibilidade do humano.

Tais trajetórias emergem a partir dos sonhos de totalização sugeridos aqui? Novamente, a resposta precisa respeitar a ambiguidade cultural. Para completar este primeiro itinerário, desejo contrastar o que devo chamar dois sonhos diferentes de totalização. Devo tomar como meus exemplos nossa própria cultura maximalista e contrastá-la com uma das culturas tecnologicamente mais minimalista por mim conhecida, a do interior dos aborígenes australianos.

Para propósitos ilustrativos, apenas porque encontrei profundas falhas em tal interpretação, devo assumir que aqueles críticos do nosso desenvolvimento histórico estão corretos em caracterizar a tendência dominante de nossa cultura Tecnológica (com “T” maiúsculo) como sendo aquela cujo sonho de totalização é gerado para trazer a natureza em si sob o controle da cultura. Se o propósito da tecnologia é controlar a natureza ou torná-la disponível para os propósitos humanos, então, interpretações tais como aquela de Lynn White Jr., que viu na história do Ocidente uma busca por poder emergindo a partir da consciência religiosa (subjugar e dominar a terra), ou esta de Heidegger, que viu o revelador poder da tecnologia moderna como tendo revelado o mundo como sendo uma fonte de "matéria-prima" (minha tradução de Bestand), estão corretas.

Se um deles toma as culturas aborígenes do interior em contraste às do litoral, pode parecer que aqui se encontra uma exceção à direção precisamente tomada por nossas histórias. Assim tomado, o exemplo é impressionante: primeiro, deve-se notar que os ancestrais dos aborígenes chegaram ao menos 40.000 anos atrás, tal como evidenciado por artefatos encontrados no Sul da Austrália; segundo, eles ficaram amplamente isolados de invasões externas e migrações (uma exceção aparentemente ocorreu no Norte por volta de três mil anos atrás quando o dingo foi introduzido; esta introdução não neutra de um cachorro selvagem conduziu à extinção do lobo marsupial, um dos poucos predadores marsupiais). Assim, os aborígenes, pode-se dizer, são uma das culturas continuamente isoladas por mais tempo no mundo.

Que eles sobreviveram afinal em tais condições áridas é impressionante, mas para terem sobrevivido de tal forma que sua cultura primária pode ser caracterizada pelo que nós podemos chamar de "atividades de lazer" é ainda mais notável. Nesse contexto, deve-se notar que pouquíssimas horas do dia são gastas juntando ou preparando comida. Muito mais tempo, relativamente, é gasto em suas versões de tempos de argumentação filosófica, de contar estórias e 
argumentar sobre o sistema mítico-religioso que se destaca por sua complexidade. Atividades de celebração tomam muito do tempo cultural comum. Casamentos, funerais e festivais sazonais duravam semanas como foi notado no tempo dos primeiros exploradores europeus. Atividades artísticas também foram destacadas, tanto em sua forma visual quanto auditiva. As pinturas em "raios- $\mathrm{X}$ " em Arnheim Land e a música Didgeridoo são hoje valorizadas pelos habitantes da nossa cultura pós-moderna.

Esta cultura milenar foi claramente uma das culturas tecnológicas mais minimalistas, não que faltassem artefatos materiais por perto, pois havia coleções de armas, incluindo a invenção dos bumerangues retornáveis e não retornáveis, lanças (pré-Idade da Pedra, as pontas eram de madeira endurecida), dispositivos para lançamento de lanças que aumentavam o poder das armas, fundas, etc., mas não o arco e a flecha encontrados virtualmente em todo o mundo em outras culturas antigas.

E se o repertório de caça dos homens deve ser igualado por um conjunto igual de tecnologias no lado da atividade feminina da coleta (e esta era o fonte de comida mais importante), então as cestas avançadas, adaptadas para carregar ovos de Emu, escavação e outras ferramentas também podem ser destacadas.

Junto à prática religiosa havia máscaras e uma ampla variedade de artefatos estético-religiosos, incluindo as famosas pinturas de pele e desenhos nas cavernas que eram representações "raios-X" de animais, ainda que o espectro seja mínimo em qualquer comparação a qualquer outro conjunto de ferramentas ou objetos manufaturados de outras pessoas não migratórias.

O conhecimento "técnico", no entanto, era vasto e complexo, particularmente no que diz respeito às fontes de alimento. Assim que comecei a estudar esta cultura, fiquei tentado a especular que um axioma central cultural podia bem ter sido: "Tudo é potencialmente comida; a única questão é como fazer isto acontecer." Os aborígenes descobriram ou inventaram processos de desintoxicação que algumas vezes tem três passos, em contraste ao processo de muitas outras culturas que são simplesmente técnicas de aquecer por fervura, assar ou imergir. A variedade das fontes de comida incluía cerca de trinta variedades de pães feitos de relva e sementes de ervas selvagens, iguarias de morcegos assados apanhados por crianças e as escassas larvas de inseto wiitchetty (uma larva de uns dez centímetros de comprimento que habitam os sistemas de raízes das árvores wittchetty). A larva é encontrada ao bater-se o calcanhar do pé de alguém ao longo da base da árvore e ouvir aos sons dos buracos por eco localização. 
Contos foram ditos sobre o espanto dos aborígenes quando os primeiros europeus tentaram cruzar os desertos centrais da Austrália. Muitos destes morreram de sede, dessecação e exposição. A resposta aborígene foi a de admirar-se, afinal como numa terra com tanta fartura alguém poderia ser tão estúpido. Para água, por exemplo, tudo o que se precisava fazer era encontrar a rachadura no chão de terra seca de uma localização apropriada e cavar cerca de sessenta centímetros até encontrar uma rã envolvida por uma membrana e, assim, cercada por água aguardando pelas próximas chuvas (o que pode significar vários anos de espera), beber a água, e comer a rã de brinde!

Aqui, então, é uma cultura minimalista que necessariamente aprendeu a lidar com um ambiente hostil. Para a cultura obter sucesso, no entanto, existem preços a serem pagos. Um segundo axioma, depois de maximizar o comestível, deve ser um direcionado a minimizar o crescimento populacional. Aqui, como esperado, há meios que podem ser encontrados: um meio incomum é uma forma de "controle de nascimento dos machos" na prática do ritual de subincisão nos adolescentes machos nos ritos da puberdade. Subincisão consiste em um buraco permanente feito na parte de baixo da base do pênis por meio do uso de um espinho inserido durante a cerimônia de iniciação. Subsequentemente, um "homem" de verdade terá que segurar este buraco quando urinando para marcá-lo como um homem. Um efeito colateral inesperado é que haverá um número limitado de espermas escapando durante o intercurso, diminuindo, assim, efetivamente, a contagem de esperma e também diminuindo a probabilidade de inseminação. É claro, medidas mais drásticas também podem ser tomadas para manter a população baixa. Associada com a crença de que nenhum casal deveria ter mais do que duas crianças (que poderiam assim ser carregados numa fuga; uma terceira teoricamente teria que ser deixada para trás), há evidência de outro método de controle de natalidade familiar no Pacífico Sul: infanticídio.

Tais preços são improváveis de serem pagos por aqueles de nós que habitam nossas próprias culturas. Similarmente, expectativa de vida, tolerância aos climas extremos e coisas do gênero não estão prestes a ser negociados por nós pela sobrevivência em tal forma de vida. E a resposta intercultural definitiva também parece ser visível bem como dentre os aborígenes de hoje, é uma cultura amplamente subsumida junto às bordas de uma cultura dominante europeia que já conta com dois séculos de duração.

Eu não disfarçarei certa admiração pela aprendizagem humana e adaptabilidade que os aborígenes exemplificam, particularmente em relação ao que eu 
chamaria de sistema ético-religioso que funcionava como um conservacionista ético. Duas crenças simples indicam como tal ética funcionava. Uma regra relata-se à proibição contra matar qualquer animal junto de seu território sagrado. O contexto para esta regra é explicado em termos não suscetíveis de serem acreditados por nós. Ele inclui elementos do totemismo, no qual os animais célebres pertencem a um grupo de parentesco (embora o relacionamento próximo entre humanos e animais é uma matéria que vai se tornando uma questão mais interessante em nosso próprio tempo).

A forma como esta regra conservativa funciona é clara. Animais podem ser comidos, mas apenas dentro de limites. De forma que isso deriva que um território sagrado é precisamente o território de reprodução e a fonte de água para o animal. Em tempo de secas severas ou em tempo de acasalamento, o animal precisa ser poupado, mesmo em condições extremas, mesmo ao ponto de que algo da tribo precise ser sacrificado em prol do animal. Dessa forma, o balanço das populações humano/animal é assegurado, assegurando, por sua vez, o futuro.

Uma segunda regra similar, novamente baseada em crenças totêmicas, diz respeito aos animais raros não utilizados ou utilizáveis. Sanguessugas, por exemplo, não podem ser mortos desnecessariamente. E a razão dada é que sanguessugas pertencem à grande série de relacionamentos que caracterizam o mundo aborígene: eles são parte do ecossistema intimamente ligado. Tal entendimento possui um significado funcional profundo num delicado ambiente de deserto. Ele é moldado em termos pré-científicos, mas é "contemporâneo" no que diz respeito a soar como um entendimento ecológico. ${ }^{14}$

O ponto aqui, no entanto, não é recomendar substituir a cultura aborígene pelas nossas, nem simplesmente romantizar o modo minimalista de vida exemplificado por aquela cultura; antes, é fazer o contraste com nossa cultura no que diz respeito ao papel relativo desempenhado pelas tecnologias. Não é simplesmente a ausência de tecnologias complexas que faz duas culturas diferentes, mas o que pode ser chamado de duas radicalmente diferentes formas nas quais o mundo é revelado. $\mathrm{O}$ aborígene também segue o sonho de totalização, mas um sonho diferente, o sonho do Dreamtime.

O Dreamtime é a "natureza" trazida junto à "cultura" de uma forma diferente do entendimento heideggeriano de matéria-prima. Ainda que toda a natureza

\footnotetext{
14 Uma discussão mais completa sobre a especificidade da ética aborígene pode ser encontrada em BENNET, David H. "Inter-Species Ethics: A Brief Aboriginal and Non-Aboriginal Comparison" Discussion Papers in Environmental Philosophy, No. 7, Australian National University, 1985.
} 
seja "levada em conta" no Dreamtime, por meio de estórias que fazem dos elementos da paisagem espaços sagrados. Assim, o promontório é "onde a goanna sonha” num longo e complexo conto que é contado e que também exemplifica alguns valores morais e tribais. Os caminhos das águas são "onde a grande cobra vagava” em algum outro conjunto de contos similares. O Dreamtime é tomar o mundo da natureza não tecnológico junto a esta cultura, ainda que isso seja uma tentativa de totalização, o modo do mundo revelado.

Funcionalmente, tal modo de revelar o mundo, particularmente quando considerado sobre mais de 40.000 anos de história destes povos, fez pouco para modificar o atual meio-ambiente. E ele foi história cultural que não desenvolveu a fascinação por invenções artefactuais que se mostra em nossa própria história.

Então, ao final deste primeiro itinerário, ao menos, existe, da mesma forma, uma igualdade em nossas trajetórias em sonhar com totalidade e uma profunda diferença. O sonho de tomar a natureza tecnologicamente para o interior de uma cultura é apresentado como pertencente à história, à nossa história. $\mathrm{O}$ enigma que aparece nesta junção é que nossa própria história distintiva parece ser a atualmente dominante. A cultura aborígene hoje é vestigial no sentido de que, com exceções isoladas, os métodos antigos não são mais transmitidos, ao menos não em suas formas originais. Mesmo a vibrante religio-arte dos povos precisa agora enquadrar-se num contexto que a reposiciona num intercâmbio transcultural, para ser considerada como uma commodity de arte não mais pertencente ao seu relacionamento Dreamtime. Mas este é o destino de virtualmente todas as culturas tradicionais deste tipo.

Existe, então, uma única e maciça trajetória para a ascensão da cultura de alta tecnologia e sua consagração como sendo a cultura mundial? Se assim for, os Marcuses, Jonas e Elluls viriam a ser os profetas para os nossos tempos. 


\section{6 \\ Programa Dois: Hermenêuticas CULTURAIS}

O primeiro programa desta análise seguiu uma ênfase mais estritamente fenomenológica sobre as experiências humanas com tecnologias. Com o segundo programa, hermenêutica cultural, uma mudança de perspectiva se faz necessária. Aqui a questão orbita em torno dos modos nos quais as culturas incorporam tecnologias. Eu tenho usado o termo "tecnologia" num sentido amplo, equivalente a certos aspectos da cultura material. Desde o princípio, tecnologia em seu conjunto é vista como pertencente de forma muito íntima às nossas culturas. E também não faltaram variações culturais nos exemplos anteriores. Ao final, eu apresentei o espectro desde as culturas tecnológicas mais maximalistas até as formas mais minimalistas de tal incorporação.

Ao nível cultural, no entanto, acontece mais do que os simples números e tipos de relações humano-tecnologia. Eu tenho sustentado que na medida em que há um número limitado de tipos de relações humano-tecnologia que seguem estruturas existenciais humanas, todas as culturas exemplificam a gama completa de tais relações (invariavelmente), embora as misturas sejam claramente altamente variáveis. Aqui o foco será em variações não consoantes, buscando os padrões que são inerentes na diversidade cultural.

Novamente a história e antropologia da tecnologia serão utilizadas, bem como variáveis imaginativas. E o meu propósito, tal como no primeiro programa, é sugerir uma estrutura diferente de interpretação, uma que possa oferecer 
uma nova perspectiva para algumas das questões contemporâneas, agora sendo tratadas como cultura tecnológica. $\mathrm{O}$ conjunto mais amplo de tais questões gira em torno da noção de uma trajetória geral da história tecnológica: o advento do domínio ocidental originado na ciência e tecnologia seria um "destino" para toda a terra? E seria tal trajetória singular? Correlacionadas a estas questões estão aqueles sobre a "autonomia" da tecnologia. Nós podemos "controlar" a tecnologia? Ou ela nos controla? A tecnologia teria se tornado Tecnologia com sua própria autonomia e saído de controle tal como um Frankenstein?

Em resposta a cada uma destas preocupações atuais sobre a tecnologia, eu proponho uma mudança de perspectiva e, com ela, a reelaboração destas questões. Tal é a tarefa de uma hermenêutica cultural. Eu devo continuar esta investigação junto à tecnologia e ao mundo da vida, e agora com uma primeira mudança no foco sobre o campo macroperceptivo dentro do qual os nossos envolvimentos corporais acontecem. A primeira investigação concentra-se no fenômeno de transferência tecnológica.

\section{A. Transferência tecnológica: tecnologias como instrumentos culturais}

Em 1930 os primeiros pioneiros australianos adentraram nas terras elevadas de Nova Guiné à procura de ouro. Eles ignoravam totalmente o fato de que aquelas terras eram povoadas por quase um milhão de outros humanos organizados em múltiplas tribos e que nunca haviam avistado homens "brancos" antes. Os australianos chegaram equipados com câmeras e gravaram alguns destes primeiros encontros (imagens que seriam depois incorporadas num documentário para a televisão, que foi complementado por entrevistas com as pessoas que ainda viviam e que se lembravam daqueles eventos).

Para os habitantes de Nova Guiné, cujo mundo pensava-se ser o único mundo, a visão destas pálidas figuras foi espantosa e eles interpretaram-nos como sendo ou espíritos que retornaram dos mortos ou divindades de algum "outro" mundo. (Este padrão de respostas foi notado em vários encontros entre culturas, seja nos antigos e modernos e, via de regra, sempre dá aos invasores uma vantagem inicial.) Apenas depois de seguir os recém-chegados e observá-los por várias semanas é que eles descobriram que eles eram, de fato, mortais. Um australiano foi avistado fazendo suas excreções matinais, e suas fezes foram 
averiguadas como tendo o cheiro propriamente "humano", concretizando assim um novo entendimento. Deuses, afinal, não urinam, defecam ou fornicam!

Tais dejetos não foram os únicos itens curiosamente inspecionados pelos tribais: cada pedaço de rejeitos e artefatos foram inspecionados. Facas de aço que foram presenteadas, ao modo transcultural clássico, foram recebidas com entusiasmo, bem como os machados de aço. Mas, curiosamente, a primeira resposta para o rifle foi ambígua. Em um dos filmes gravados, um prospector demonstrou o poder do rifle. Ele atirou num porco (de muito perto, atirando no focinho não mais do que centímetro da cabeça do animal); e enquanto o tiro em si causou certo espanto, a capacidade de matar o porco a tal distância aparentemente não foi impressionante. Apenas depois, quando os prospectores passaram a ser vistos como sendo humanos é que seus artefatos foram entendidos como desejáveis e valendo uma incursão. Tal incursão foi organizada com desastrosos mais previsíveis resultados: muitos papuásios foram mortos pelo poder de fogo do rifle. Depois deste evento, os rifles eram entendidos como armas poderosas, posses de alto valor.

Se a assimilação imediata de facas e machados de aço é compreensível e se o exemplo das armas permanece parcialmente ambíguo, mais curioso foi a resposta às latas de sardinha ovais deixada para trás pelos australianos. Elas foram imediatamente arrebatadas pelos papuanos como objetos partes de um tesouro e prontamente transformadas em peças centrais do elaborado adorno de cabeça que usavam em ocasiões especiais. A lata de sardinha foi colocada no centro da testa, uma posição ocupada anteriormente pelas grandes conchas que tinham forma semelhante.

Uma análise padrão, esboçada com base em algumas ideias heideggerianas, é o suficiente para explicar os exemplos do machado e da faca de aço. Essas ferramentas foram imediatamente entendidas por suas formas e funções para serem inseridas numa práxis já existente. $\mathrm{O}$ que a análise econômica e cultural padrão acrescentará é que, ao receber o machado e a faca de aço, o papuásio está recebendo mais que um mero artefato. Ele está potencialmente recebendo um conjunto de relações culturais, neste caso, as relações que criarão uma situação de dependência junto à cultura na qual está adentrando. ("Cuidado com os australianos que trazem um presente"?)

Da mesma forma como não existe tal coisa como "um" equipamento, também não há um equipamento sem que ele pertença a algum conjunto de valores e processos culturalmente construídos. À medida que o machado e a faca de 
aço se tornam mais desejáveis e que o seu modo de produção não está disponível para o papuásio, os novos objetos devem ser obtidos por alguma forma de troca, cujas histórias são múltiplas e conhecidas o suficiente para serem citadas aqui. Porém, além de agora juntar-se em um novo conjunto de intercâmbios interculturais, deve-se também notar que o contexto do objeto anteriormente familiar, neste caso, facas e machados de pedra, também mudam seu valor e posição junto à cultura. Quaisquer que sejam os aspectos, as crenças e os rituais envolvidos, a fabricação de ferramentas de pedra está destinada a desaparecer assim que os equipamentos entram em desuso.

Um empréstimo semelhante por parte dos nativos de Poluwat, navegadores do Pacífico Sul, ilustra melhor a mudança perceptiva-cultural que acompanha essas transferências de tecnologia. Esses nativos navegavam com base nos padrões de ondas, sem o uso da bússola

Uma vez que se familiarizaram com a bússola, esses navegadores adotaram amplamente o seu uso, primeiramente porque a bússola era um objeto de fascinação, antes de ser algo necessariamente útil. A bússola conferia prestígio. No entanto, uma vez que foi adotada e utilizada para um de seus propósitos, que era orientar um curso reto, tornou-se possível deixar de lado (des-aprender) as mais difíceis percepções sobre as ondas, as quais eram parte de um complexo processo de iniciação em maricultura. A complexa rede de envolvimentos à qual a bússola pertence na navegação ocidental, isto é, os referentes matemáticos ao complexo de direções (focado num esquema polar), latitude e longitude, etc., nunca foi adotada pelos nativos Poluwat. A bússola, portanto, tem um "ser" diferente no uso em Poluwat do que em seu uso ocidental.

Voltando aos papuásios, os dois exemplos citados tornam-se compreensíveis junto às primeiras aproximações da práxis existente, desde que não entendamos que a práxis dever ser modelada unicamente com base em considerações econômicas e de eficiência. O exemplo da lata de sardinha tornando-se adorno incorpora um novo artefato em uma práxis de "moda" preexistente. Tal práxis, por sua vez, incorpora em seu contexto de significância o status e a identidade do portador de formas não necessariamente muito distantes das nossas próprias intencionalidades de moda.

O exemplo do rifle também se torna compreensível, embora de uma maneira ligeiramente mais difícil, se for entendido como estando relacionado a uma práxis já familiar. A guerra e o assassinato de inimigos eram bem conhecidos pelos papuásios, mas a forma e função do rifle não eram familiares como 
tal. Somente quando se tornou aparente que esta nova arma poderia ser usada à distância (algo como uma lança) é que seu valor pôde ser visto. A função, pelo menos, tornou-se perceptível assim que seu contexto de uso foi plenamente demonstrado.

A adaptação de uma tecnologia transferida depende, em primeiro lugar, pelo menos de ser capaz de encaixar-se numa práxis preexistente. Mas mesmo quando adaptada, o contexto de significações pode diferir radicalmente em relação ao tipo sedimentado de práxis na cultura receptora. Não é preciso ir para os exemplos culturais mais exóticos para tomar nota desde fenômeno.

Os trabalhos de Lynn White Jr., Joseph Needham e Daniel Boorstin têm documentado amplamente as transferências tecnológicas históricas que demonstram tais disjunções transculturais na nossa própria história. No seu "Cultural Climates and Technological Advance in the Middle Ages", White aponta para o que ele entende como a fome de poder e aplicação prática no Ocidente Latino, contrastando com um contexto muitas vezes mais meditativo tanto no Grego como no Extremo Oriente. Essa transferência ocorre nos novos usos que os empréstimos foram colocados quando transportados para o Ocidente.

O exemplo previamente citado das rodas de oração indianas tecnologicamente transferidas e tornando-se moinhos de vento no Ocidente é também um exemplo de duas incorporações culturais diferentes. No Ocidente, já acostumado a ver a natureza como um recurso utilizável, muito antes do que foi creditado por Heidegger, o poder do vento foi adaptado a uma variedade de usos energéticos, como bombear água, moer grãos, serrar madeira. White aponta que os países islâmicos, como o Irã e o Afeganistão, também inventaram um moinho de vento, mas apesar da óbvia necessidade do poder para a irrigação, essas fontes de energia nunca foram transferidas das fontes locais de uso para outras terras islâmicas e assim não se tornaram o que elas foram para a Europa. ${ }^{1}$

White igualmente traça a história e o desenvolvimento do que devia ter se tornado os contrafortes de voo das grandes catedrais góticas de arco ogival (Índia, segundo século) com uma migração mais gradual para o Oeste rumo a uma igreja em Monte Cassino (1071), até a sua adaptação para as alturas inauditas demandadas em Cluny (1088). No entanto, o que viria a ser o apogeu da construção de catedrais também deve seu passado a um empréstimo, substituído em uma diferente expressividade na Europa. ${ }^{2}$

1 WHITE JR., Lynn, 1971, p. 176.

2 Ibid, p. 183-85. 
O desejo cultural para expressar o poder é claramente posto na ordem para a construção do Duomo em Florença: "A República Florentina, que se eleva sempre acima da concepção dos juízes mais competentes, deseja que um edifício seja construído, tão magnífico em sua altura e beleza que superará qualquer coisa da mesma espécie produzida nos tempos dos gregos e romanos em seu apogeu de poder".

Em cada um destes exemplos, uma "tecnologia” foi transferida, mas há também um sentido, na medida em que há um conjunto duplo de envolvimentos contextuais em que "uma" tecnologia não é o que foi transferido.

O duplo contexto é este: primeiro, há o envolvimento do artefato dentro de seu contexto de uso imediato. Ele "é" o que é em relação a este contexto. $\mathrm{Na}$ medida em que tais contextos, particularmente nos níveis mais simples, podem ser generalizados em relação às culturas, uma transferência é uma questão relativamente simples (machados e facas de aços pelos de pedra). É menos assim se o contexto dos envolvimentos instrumentais forem complexos, particularmente implicando algum processo hermenêutico específico aprendido (o exemplo da bússola). Em cada caso, o artefato torna-se tecnologicamente o que "é" em relação ao grau e tipo de transferibilidade com que as respectivas culturas se sobrepõem na prática. Aqui a sobreposição pode ser mínima.

Mas, em segundo lugar, há também a justaposição de contextos culturais maiores, que podem não sobrepor-se. E o artefato "ê" o que é também em relação a este campo cultural. Há, portanto, um sentido em que o "moinho de vento" como moinho de vento não foi transferido. Os meros aspectos técnicos da roda de oração não se tornam um moinho de vento até serem reconstituídos dentro do novo contexto cultural. Este contraste foi observado por estudos de Joseph Needham de um conjunto desenvolvido de tecnologias na China em comparação com a Europa: pólvora e fogos de artifício contrastam com os mesmos materiais utilizados no cerco e na guerra.

A tentação pode ser forte aqui para saltar a uma conclusão sem contexto de que a "tecnologia" como tal é "neutra", mas assume seu significado dependente de diferentes "usos". Mas tal conclusão permanece no máximo como uma espécie de abstração desincorporada. A tecnologia é apenas o que é em algum contexto de uso. Mesmo as tecnologias descartadas, seja nos museus da ciência e da indústria, as ruínas de uma paisagem, ou reutilizado em uma construção de bricolagem, continuam a indicar a sua "utilidade" perceptível. 
Nesse contraste de tecnologias transferidas entre culturas, começam a surgir pistas sobre os mais altos níveis de complexidade tecnológica. Considerando que a fenomenologia anterior poderia, e corretamente, reduzir sua análise às experiências de tecnologia humana (experiências em que tanto as tecnologias simples como as complexas podem cair em formas de incorporação simples ou relações hermenêuticas facilmente aprendidas) no fenômeno da transferência de tecnologia, quanto mais complexas as tecnologias, tanto mais difícil de efetuar uma transferência. Eu não estou aqui determinando que tecnofatos complexos não são introduzíveis. Pelo contrário, precisamente porque são muitas vezes facilmente introduzíveis, surgem os problemas mais profundos da transferência de tecnologia.

Se os objetos transferíveis com facilidade em anos passados de exploração eram facas e machados de aço acrescidos por sinos de falcoaria e contas, espelhos e assim por diante, no neocolonialismo de hoje os objetos de fascínio mais desejáveis são relógios de pulso, rádios e televisores, calculadoras e computadores. Essas transferências repetem de forma mais contemporânea algumas das características vistas antes.

$\mathrm{O}$ rádio e o relógio carregam características particularmente fascinantes. O relógio, mesmo num contexto cultural sem contagem de tempo e sem relógio, transforma-se num badulaque admirado. Seus movimentos e sons são fascinantes. Como uma pulseira, é também um objeto de moda de prestígio. A práxis da moda em que se encaixa um relógio é praticamente universal. O rádio ainda mais. Ele pode transmitir sons já familiares ao destinatário. Nunca esquecerei a primeira vez que ouvi um pregador Xhosa entoar na rádio africana.

Os novos artefatos, ao mesmo tempo em que implicam infraestruturas complexas de alta tecnologia cultural para a sua produção, ainda não transcendem, neste nível, a simples transferência de objeto-uso da práxis. Assim, pode haver um fluxo de artefatos e tecnofatos que ainda não transformam massivamente as culturas. No transporte aquático, por exemplo, enquanto a vela tem sido muitas vezes substituída pela potência do motor e as variedades de poder são altamente variantes, desde os motores de popa até os "barcos de cauda longa" do Sudeste Asiático, que usam motores automotivos para desempenho de alta velocidade, os tipos de artesanato que são utilizados ainda são os artesanatos da região; e as cargas e os carregamentos foram pouco alterados desde tempos anteriores. Ao passo que isto ainda caracteriza a prática, aqueles que defendem "tecnologias apropriadas" podem ter um ponto. A interface cultural, entretanto, 
ocorre em dois níveis: o nível de envolvimento instrumental, que como temos visto tem muitas sobreposições nos níveis diários, e o nível mais complexo de valores culturais mais elevados e sua complexidade associada. Pode fazer pouca diferença imediata se um relógio de pulso é usado como um objeto de moda, mas se ele transporta com sucesso em sua esteira a transformação de uma sociedade inteira em uma sociedade regulada pelo relógio com seu tempo social associado, então um grande problema está envolvido.

É necessário aqui um exemplo mais complexo no qual as "mesmas" tecnologias estão incorporadas de forma diferente em desenvolvimentos aproximadamente equivalentes da cultura. Um exemplo brilhante disso relaciona-se mais uma vez com aquela invenção primordial, o relógio, e a forma como o tempo é percebido e usado. Já vimos o exemplo ocidental através de Mumford e Heidegger e a forma como o relógio se tornou um instrumento para regular o tempo social e uma descrição da própria natureza. Daniel Boorstin forneceu um exemplo diferente, a forma como os relógios foram incorporados na história chinesa antes da era moderna.

A civilização chinesa antiga era, em seu contexto surpreendentemente sofisticada e, ao contrário da maioria das civilizações antigas, altamente desenvolvida em seu conhecimento de astronomia ou fenômenos "celestiais". Como em muitas outras civilizações antigas, os movimentos celestes anunciaram muito mais do que movimentos mecânicos das estrelas e dos planetas. Um exemplo universal próximo da astronomia antiga é alguma versão da astrologia em que os movimentos celestiais são pensados (hermenêutica) relacionados aos processos existenciais. A astronomia chinesa era suficientemente precisa para que a previsão mais antiga de um eclipse fosse registrada em 1361 a.C. O instrumento hermenêutico que registra e reflete esses movimentos é o calendário. E, como veremos, é um calendário preciso, que, por sua vez, se relaciona com o primeiro relógio chinês.

Esse relógio, supostamente inventado pelo astrólogo imperial Su Sung, em algum momento, pouco depois de 1077 (não muito diferente de uma data da invenção dos primeiros relógios mecânicos na Europa) não era para contar as horas, mas para definir o calendário astrológico para uma necessidade imperial:

O próprio Imperador tinha uma necessidade especialmente íntima por um calendário cronometrado. Para cada noite, o Imperador, em seu aposento para dormir, tinha que saber os movimentos e as posições 
das constelações em cada momento, precisamente à maneira que o relógio celeste de Su Sung tornou possível.

Quando Su Sung construiu seu relógio imperial, o Imperador tinha que atender a um amplo número de esposas e concubinas de várias categorias [...] incluindo uma imperatriz, três consortes, nove esposas, vinte e sete concubinas e oitenta e uma concubinas assistentes. Sua rotação no dever, tal como descrito no Registro dos Ritos... é a seguinte:

As categorias mais baixas vêm primeiro, as mais altas vêm em último lugar. As concubinas auxiliares [...] dividem o sofá imperial nove noites em grupos de nove. As concubinas... são distribuídas três noites em grupos de nove. Às nove cônjuges e às três consortes são permitidas uma noite a cada grupo, e a imperatriz, sozinha, uma noite. No dia quinze de cada mês, a sequência é completa, após o que se repete em ordem inversa. ${ }^{4}$

Um trabalho complexo para os cronometristas, clamando claramente pro um relógio!

Após esse pico de desenvolvimento e uso do relógio, no entanto, o relógio foi abandonado na China e reintroduzido muito mais tarde pelos jesuítas na época de Galileu. Mas novamente, enquanto o relógio se tornou a máquina para os jesuítas, sua reintrodução permaneceu ligada à curiosidade relativa aos autômatos (outra característica de curiosidade quase universal entre as culturas). Logo começou um fluxo de relógios baratos da Europa para a China, onde permaneceram em grande parte como objetos de arte.

Em suma, o relógio “e’” o que é em relação à sua matriz cultural incorporada que, na China até os tempos modernos, permaneceu muito diferente da do Ocidente. Um breve vislumbre de alguns desses valores contrários pode ser instrutivo: (1) A centralização oficial no cargo do Imperador mantinha todos os calendários como propriedade da casa imperial. (2) Os imperadores foram mantidos ocultos do público e, enquanto poderosos como decretadores, isolados da vida pública. (3) A manutenção do calendário relacionava-se com as características astrológicas importantes, como previsões sociais, particularmente

4 BOORSTEIN, Daniel J. The Discoverers. New York: Vintage Books, 1985, p. 76. Este livro é uma obra admirável sobre a históriadas invenções tecnológicas e o papel que elas desempenham, não apenas no Ocidente, mas também em culturas mundiais. 
focadas nos confins imperiais. Enquanto o relógio foi mantido para este contexto, ele também foi isolado.

Cada um desses fatores contrasta diretamente com a introdução latino-ocidental do relógio que foi pública, cronometrada e socialmente adaptada. Aqui, então, é um exemplo de uma tecnologia claramente importante que "é" o que é dentro de um contexto cultural. Deve-se notar que, como um dispositivo hermenêutico, um relógio tem claramente um conjunto multidimensional de possibilidades, que, por sua vez, pode caber facilmente em um número de estruturas culturais, multiestáveis. Nesse sentido, o relógio é um exemplo paradigmático da ambiguidade essencial, embora não neutra, da tecnologia. E nos exemplos que acabamos de assinalar, enquanto o artefato foi transferido, quase se poderia dizer que a "tecnologia" não fora. Ou, no que persiste num análogo de um dispositivo hermenêutico para um texto, o "texto" foi transferido, mas certamente era lido diferentemente. Somente quando todo o processo de leitura é também transferido é que o relógio poderia tornar-se a "mesma" tecnologia.

O exemplo do relógio chinês reverbera de maneira interessante com o exemplo anterior de Papua-Nova Guiné. O relógio chinês é um exemplo de uma resistência cultural bem-sucedida a uma "cultura de relógio" ocidental, pelo menos, até os tempos modernos e até que a estrutura da sociedade chinesa e da própria cultura mudou. Mas também é uma diferença entre estilos de civilizações. A cultura tribal que, ao aceitar o machado de aço, aceita inadvertidamente um conjunto de relações de dependência (como os "cultos de carga" de Papua-Nova Guiné, que são religiões tentando atrair magicamente aviões para a terra trazendo seus bens aos praticantes), realmente obtém mais do que um simples machado de aço.

Entre as extremidades de resistência bem-sucedida à cultura-tecnologia e sua contrapartida de aceitação rápida, estão as adaptações aproximadas nas quais as tecnologias ("apropriadas") selecionadas são adaptadas sem maiores ou totais desfigurações de culturas indígenas (exemplos do Sudeste Asiático). Estou aqui a ler a situação para ser empiricamente mista e não, como alguns intérpretes teriam feito, a marcha desimpedida da cultura ocidental de alta tecnologia sobre e apesar de toda a resistência cultural. 


\section{B. Neocolonialismo como a falha da transferência}

O puro poder e a concentração do poder tecnológico e científico nas nações de alta tecnologia do Hemisfério Norte é, evidentemente, um fato indiscutível. Mas também é um fato ambíguo. Ele aponta para uma relação muito mais profunda entre tecnologia e cultura e o encaixe do primeiro no segundo. O que não é transferido com êxito é precisamente a infraestrutura necessária para o desenvolvimento autônomo (de tais tecnologias), no entanto tal desenvolvimento é avaliado.

Em um levantamento do desenvolvimento da ciência e da tecnologia por um grupo dirigido por Aaron Segal, o contraste entre a pesquisa e o desenvolvimento no "primeiro" e no "terceiro" mundo é indicado para demonstrar as disparidades entre estes mundos. A medição de tais fenômenos não é uma tarefa simples, mas as estatísticas brutas são pelo menos indicativas da presença ou não da infraestrutura.

A constelação dos países que possuem tais estruturas autônomas claramente inclui Canadá e Estados Unidos na América do Norte e URSS; apenas em algum sentido os países do Leste Europeu; certamente a Europa Ocidental, mas apenas o Japão, plenamente, na Ásia (com a Coréia e a Índia como potências num alcance menor e a China com um médio poderio), e as exceções isoladas de Israel e África do Sul e a Austrália e Nova Zelândia no Pacífico Sul. Todos os demais - aproximadamente 150 países - possuem ao menos algum desenvolvimento parcial de alguma infraestrutura ou são dependentes de infusões dos países anteriormente mencionados.

Os países citados são responsáveis por $97.1 \%$ de todos os investimentos mundiais em pesquisa e desenvolvimento e têm associados a tal desenvolvimento $87.4 \%$ de todos os cientistas e engenheiros do mundo. Isto deixa os demais 150 países não mencionados com apenas $2.9 \%$ dos demais investimentos financeiros e apenas $12.6 \%$ do rol de cientistas e engenheiros disponíveis para o desenvolvimento infraestrutural. Eu vejo isto como um fracasso massivo em transferir justamente aqueles aspectos da cultura que dariam suporte ao desenvolvimento futuro das tecnologias de ponta. ${ }^{5}$

Não estou aqui me comprometendo a avaliar se esse fracasso é uma coisa boa ou ruim. Estou observando que o que é retratado como a marcha bem-sucedida

5 SEGAL, Aaron. Learning by Doing: Science and Technology in the Developing World. Boulder: Westview Press, 1987, p. 2-3. 
da cultura tecnológica não é aquilo que, às vezes, é apresentado como se fosse. Somente sob a perspectiva de uma missão ocidental pré-comprometida é que a ausência de tal infraestrutura poderia ser interpretada como uma "falta” (como é assim interpretada por aqueles que defendem a plena transferência cultural-tecnológica).

E mesmo quando um país se compromete publicamente com a tecnologização, os resultados são, na melhor das hipóteses, parciais. A Índia é um exemplo interessante de um país do Terceiro Mundo fortemente empenhado em criar sua própria infraestrutura de ciência e tecnologia: primeiro, a Índia é um dos melhores exemplos de um colonialismo "bem-sucedido", se por isso se entende que muitos dos valores positivos do poder colonial foram incorporados aos valores do país depois da independência. Não só a Índia se tornou um Estado-nação socialdemocrata independente com uma burocracia em grande parte baseada na Grã-Bretanha, mas até mesmo sua linguagem nacional funcional permanece em inglês. E durante cem anos (1850-1950), pelo menos, a ciência e a tecnologia ocidentais fizeram parte dessa presença colonial. Os observatórios astronômicos extremamente impressionantes construídos em 1724 em Nova Deli e Jaipur, que continham instrumentos monumentais capazes de medir eventos astronômicos importantes com a precisão de segundos, foram, no entanto, primariamente motivados pelo desejo de ter os instrumentos astrológicos mais precisos possíveis.)

No tempo de sua independência, a Índia encontrava-se também seguindo os caminhos contraditórios desenhados por seus mais proeminentes fundadores, Gandhi e Nehru. Como Briejn Gupta aponta:

O primeiro [objetivo] foi atender ao desafio das expectativas crescentes do povo indiano em suas necessidades materiais e sociais mais fundamentais, como alimentos, abrigo, saúde e trabalho. O outro tem sido eliminar ou, pelo menos, diminuir as relações industriais e tecnológicas dependentes "coloniais" ou "satélites" com os países avançados do Norte e assim afirmar maior autonomia econômica e política no sistema internacional. Para sua tristeza, a Índia descobriu que a ciência e a tecnologia apropriada para o primeiro fim não são a ciência e tecnologia adequadas para alcançar o segundo objetivo. ${ }^{6}$

6 GUPTA, Brijen apud SEGAL, 1987, p. 189. 
A direção gandhiana, caso tivesse prevalecido, teria mantido mais da cultura pré-moderna da Índia:

Com força intransigente, Gandhi se opôs ao que ele chamou de "anglicismo mímico", isto é, roupas ocidentais, vida burguesa ocidental, igualitarismo ocidental e desejo ocidental de obter riqueza e melhorar indefinidamente seu padrão de vida... Então ele pregou... Ramarajya, o reavivamento da antiga comunidade autônoma de aldeia onde as pessoas permaneceriam pobres, mas não na pobreza, porque não aspiravam a consumir mais que pudessem produzir na aldeia ou obter em troca da próxima aldeia. ${ }^{7}$

Aparentemente, um passeio pelo interior da Índia mostra que a vida na aldeia, com ou sem a aceitação de ser pobre, está próxima da regra na realidade, mas, ao mesmo tempo, tem havido um compromisso governamental maciço com o ideal Nehru de modernização tecnológica.

Este ideal, incorporando engenharia pesada, institutos de pesquisa científica e energia elétrica, ainda caracteriza o impulso principal da política indiana contemporânea. Os avanços foram enormes por meio de medidas de multiplicação: (1) Desde a independência em 1948, com uma base de 1,1 milhões de rupias em Pesquisa e Desenvolvimento (PD) até os 1.044,9 milhões em 1984 (medição mais recente), e de uma base 0,23\% do PIB em investimento em PD para $0,83 \%$ de um PIB maior em 1983, notam-se multiplicadores não encontrados em qualquer nação ocidental. ${ }^{8}$ (2) O número de pessoal envolvido em atividades de PD cresceu na mesma curva exponencial. Do minúsculo número de graduados de 188 em 1950, a Índia produz hoje cerca de 2200 graduados (1985, a estatística mais recente) a partir de suas próprias fontes. Ainda assim, estes números são claramente muito pequenos, considerando o tamanho do país (700 milhões de habitantes).

No entanto, a ironia é que isso é "superprodução", dada a infraestrutura que apoia a pesquisa em prol da alta tecnologia. Hoje, a Índia é efetivamente um "exportador" de recursos humanos em ciência e tecnologia. Gupta, apontando para essas conquistas, observa:

A Índia ainda não foi transformada em uma comunidade tecnologicamente orientada... Há um desemprego maciço de pessoal técnico e

7 Ibid., p. 192.

8 Ibid., p. 199-200. 
científico, com aproximadamente $12 \%$ dos recém-licenciados incapazes de encontrar emprego produtivo no prazo de três anos após sua graduação. Esta situação seria pior se o governo não fosse o empregador de aproximadamente $65 \%$ de todos os graduados de engenharia. ${ }^{9}$

A Índia é um “exportador” em outro sentido também. Quando estive na Índia em janeiro de 1988, soube que todos os graduados do Instituto de Tecnologia de Bombaim (um dos mais prestigiosos dos seis institutos da Índia, modelados em uma versão de graduação do MIT) nas áreas de engenharia elétrica, informática e engenharia material foram bem-sucedidos ao ingressar em faculdades de pós-graduação nos Estados Unidos. A expectativa era que, se dez por cento desses estudantes retornassem à Índia, a taxa de sucesso seria boa. E o que pode não ser percebido neste cenário é que os Estados Unidos se tornaram uma nação "importadora” em relação à engenharia no nível de pós-graduação.

A Revista Science analisou por algum tempo a situação nas faculdades americanas de engenharia. Uma grande enquete foi realizada no outono de 1985, e as conclusões foram sintetizadas no "O Impacto dos Estudantes Estrangeiros na Formação em Engenharia nos Estados Unidos”:

As respostas fornecidas pelos professores e pessoas envolvidas com as engenharias indicam que os estudantes pós-graduandos estrangeiros têm assumido um papel importante nas Faculdades de Engenharia nos Estados Unidos, dado à escassez de pós-graduandos norte-americanos. Os estudantes estrangeiros foram vistos não apenas como substitutos necessários aos estudantes americanos, mas geralmente também como substitutos satisfatórios. ${ }^{10}$

Atualmente, mais de $60 \%$ dos estudantes de engenharia (na minha universidade, $83 \%$ ) e mais de $35 \%$ dos professores-assistentes são estrangeiros, com um grande número destes vindos da Ásia, incluindo a Índia. (Uma razão para a escassez de estudantes de engenharia de pós-graduação dos Estados Unidos está relacionada aos altos salários disponíveis para os bacharéis graduados. Nossos jovens impacientes aparentemente querem uma gratificação mais imediata.) Informalmente, não difícil de encontrar nossos gestores das universidades admitindo que se não fosse pelos estudantes estrangeiros, muitas destas faculdades de

9 Ibid., p. 205.

10 Science, 3 de abril, 1987, p. 36. 
pós-graduação teriam dificuldades. Nós precisamos destas “importações” para manter o nosso próprio establishment.

No contexto aqui, contudo, estes fenômenos são indicadores do fracasso da transferência tecnológica para os países do terceiro mundo mesmo neste caso, num país que adotou oficialmente uma posição pró-ciência e tecnologia. Evidentemente, de modo contrário, a política é um sucesso. O engenheiro imigrante (e doutor e cientista) mantém nossa própria cultura tecnológica prosperando. O número crescente de coautores com sobrenomes indianos na literatura científica é o indicativo do sucesso reverso.

O que não está sendo transferido é o que pode ser chamado de componente-chave da cultura tecnológica, a infraestrutura científica-tecnológica. Para as nações desenvolvidas, esta infraestrutura abarca a educação científica como parte de sua cultura. Educação científica pode ser concebida como uma ferramenta cultural da alta tecnologia. Aqui, novamente, Heidegger foi presciente. Em seu "A questão da Técnica", ele argumenta a partir de uma inversão do modelo usual de entendimento da relação entre ciência e tecnologia. Para Heidegger, é a tecnologia moderna que é "ontologicamente" a origem da ciência moderna. Num contexto mais restrito que este, Heidegger argumenta que a física (a ciência paradigmática fundacional) é a "ferramenta" da tecnologia como abertura de mundo predominante encontrada no Ocidente.

Primeiro, a ciência moderna torna-se ciência tecnológica no previamente notado sentido de ser instrumentalmente incorporado:

É dito que a tecnologia moderna é algo incomparavelmente diferente de todas as tecnologias prévias porque ela é baseada sobre a física moderna como uma ciência exata. Enquanto isto, nós temos entendido mais claramente que o inverso mantém-se também verdadeiro: a física moderna, enquanto experimental, é dependente dos aparatos tecnológicos e do progresso na produção dos aparatos. ${ }^{11}$

Conceitualmente, também, a física moderna desempenha um papel como um instrumento da visão tecnológica:

A maneira de representar da ciência moderna persegue e aprisiona a natureza como uma coerência calculável de forças. A física moderna não é a física experimental porque aplica o aparelho ao questionamento

11 HEIDEGGER, Martin. “The Question Concerning Technology,” Basic Writings, ed. David F. Krell. New York: Harper and Row, Publishers, 1977, p. 295-96. 
da natureza. O inverso é verdadeiro. Como a física, de fato, já como teoria pura, coloca a natureza para se exibir como uma coerência de forças calculáveis, antecipadamente, ordena suas experiências precisamente com o propósito de perguntar se e como a natureza se reporta quando criada dessa maneira. ${ }^{12}$

Este modo de conceber, ou este modo de ter a natureza revelada, o que, para Heidegger, constitui a visão de mundo da cultura tecnológica: "Porque a essência da tecnologia moderna repousa em enquadrar, a tecnologia moderna precisa empregar a ciência exata da física. Ao assim proceder, surge a ilusão deceptiva de que a tecnologia moderna é ciência da física aplicada." ${ }^{13}$

O que Heidegger viu é que a ciência (neste caso, a física) desempenha o papel de instrumento conceitual dentro do contexto mais amplo de um modo de natureza reveladora, tomado como matéria-prima. Mas a mesma relação se mantém de outra forma dentro da matriz cultural. Uma condição de suporte para uma cultura de alta tecnologia é uma educação científica intensiva como parte da infraestrutura, que apoia o empreendimento. Este fator crucial separa os desenvolvimentos do primeiro e do terceiro mundo. Assim como a infraestrutura geral está ausente, tão especialmente é a intensidade da educação científica, que é importante como um motor cultural.

Um indicador dessa intensidade pode ser encontrado nas múltiplas facetas de uma preocupação com a educação científica dos órgãos oficiais cujos interesses estão estimulando a ciência. Dentro do orçamento da National Science Foundation (NSF), por exemplo, há uma rubrica de US\$ 139 milhões para a educação científica. E embora esta seja uma pequena parte do orçamento global de quase 2 bilhões de dólares da NSF, essa rubrica é maior do que todo o orçamento do National Endowment for the Humanities (US\$ 137 milhões). Fora deste programa da NSF há o emprego de publicidade muito direcionada para a ciência e educação de ciências, incluindo chamadas na televisão durante a programação infantil de sábado de manhã. Da mesma forma, na mídia, praticamente todos os jornais têm uma coluna de ciência. Hoje a televisão é inundada com documentários científicos produzidos com os últimos avanços técnicos e, mais uma vez, a maioria da programação infantil têm regularmente programas como "Mr. Wizard". Para o jornalismo científico, escrita técnica e outras necessidades, existem programas voltados para manter a educação científica e suas

12 Ibid., p. 303.

13 Ibid., p. 304. 
realizações à vista do público. Tudo isso faz parte de uma intensidade acima e além do currículo educacional, que apresenta componentes pesados de ciência do jardim de infância até a faculdade.

Embora possa ser que a publicidade científica americana seja mais intensa do que a de outros países industrializados, dentro da própria educação, a educação científica continua a ser uma parte importante de todos os países tecnologicamente orientados. Há uma competição virtual sobre realizações comparativas. Os maiores escores de matemática e ciência das crianças na Europa e na Ásia desenvolvida, especialmente no Japão, estimulam os apelos à reforma educacional nos Estados Unidos. O medo de ficar para trás nesta competição também pode ser visto em uma campanha de publicidade recente para computadores domésticos. Apenas alguns anos atrás, sob um programa do Conselho de Nova Iorquek para as Humanidades, um tema que relacionava as humanidades com a tecnologia, o discurso mais popularmente utilizado estava sob um título inventado por um dos convidados: "Pac Man e Eu: Crianças na Era do Computador". Associações de Saúde Mental em todo o estado reuniam as famílias todas as noites para debater este tópico, com os pais comparecendo em grande número, em grande parte em resposta à propaganda de televisão, então popular, que falava sobre temores de "Johnny" ficar para trás se seus pais não se apressassem em comprar um PC.

Estas vinhetas são apenas indícios da atmosfera cultural em que a ciência e a educação científica mantêm um foco central na e para a juventude. O objetivo agora é muitas vezes chamado de "alfabetização tecnológica", mas é principalmente uma tentativa de promover o pensamento quantitativo em todas as áreas. Tal é o programa no "New Liberal Arts" patrocinado pela Fundação Sloan. Este programa, voltado para as faculdades de artes liberais de elite (na crença de que se adotarem tal currículo, as outras faculdades seguirão o exemplo), introduz o pensamento quantitativo e a relevância tecnológica em cursos tão diferentes quanto o de composição musical (computadores), história e artes.

Todos esses esforços são parte do processo de aculturação projetado dentro das culturas tecnológicas. Sem esses esforços concentrados, faltariam os pontos de vista que permitem e fomentam a cultura. E este esforço educacional representa um contraste tão grande entre os contextos do primeiro e do terceiro mundo ao mesmo modo como a diferença anteriormente mencionada em dólares investidos em Pesquisa e Desenvolvimento e no número de pesquisadores cientistas e engenheiros. A educação científica é um equivalente contemporâneo 
à iniciação tribal, pelo menos em termos culturais. Sem essa dimensão da cultura mais ampla, a transferência de tecnologias complexas que interligam e formam sistemas continuará a ser difícil. Essas tecnologias permanecem o que elas "são" em relação à forma como elas se tornam incorporadas nas culturas; sem a preparação cultural, a transferência continua frustrada.

Tudo isso é reconhecido, em certo sentido, pelos países de médio alcance que gostariam de "saltar" para um desenvolvimento tecnológico mais elevado. Um instrumento frequentemente usado para este propósito, talvez o instrumento do paradigma "cultural", é a televisão. Como o rádio e o relógio, uma televisão é facilmente introduzida, apesar de a televisão ser uma das mais complexas tecnologias de alta tecnologia do nosso tempo. Seus envolvimentos instrumentais incluem sistemas de eletricidade, um sistema de satélites espaciais (para países do terceiro mundo), algum sistema de distribuição e produção, seja governamental ou industrial, bem como a complexa tecnologia do próprio conjunto. No entanto, cultural e perceptivamente, a televisão é uma tecnologia "simples", na medida em que o que a tela apresenta é fácil e culturalmente percebida. Um dos exemplos mais simples são os desenhos infantis: com um mínimo ou nenhum diálogo, os personagens e os enredos são facilmente aprendidos, e meu filho de dois anos de idade conhece os vídeos "Winnie the Pooh" de trás para frente, com antecipações, citações de diálogos, etc. Uma tecnologia contrastante é a pequena calculadora. Embora este dispositivo seja pequeno, portátil e, uma vez fabricado, praticamente autônomo de qualquer sistema de entrega, é um dispositivo hermenêutico que precisa de um nível de "conhecimento de leitura", isto é, de matemática, para ser colocado em seu uso "adequado". Mais uma vez, meu filho de dois anos de idade sabe muito bem como apertar os botões e fazer os números aparecerem. Mas ele não "percebe" o significado projetado e utilizando a ambiguidade essencial de usos múltiplos do dispositivo muitas vezes o mantém em seu ouvido e imita um telefone portátil. Isto quer dizer que Mark já compreende a ambiguidade das tecnologias na medida em que elas podem (pelo menos, para o mundo imaginativo da criança) encaixar-se em uma multiplicidade de usos. A calculadora em si não pode determinar nem os seus usos, nem os contextos nos quais será feita a adaptação. Poder-se-ia exibi-lo como um fenômeno perceptivo interessante, mas é duvidoso que tal fascínio duraria muito tempo. Mesmo se a televisão se encaixar em um contexto diferente nos países em desenvolvimento e nas sociedades do Hemisfério Norte (onde está 
presente no lar), ela está presente como um foco comum e pode ser encontrada em praticamente todas as aldeias indianas em uma casa pública.

A televisão é um instrumento cultural em um duplo sentido. Trata-se de um exemplo concreto de uma tecnologia transferida, trazendo consigo um contexto de envolvimentos que as altas tecnologias têm com sistemas mais amplos, e é também um instrumento cultural na programação e no conteúdo, propriamente ditos. Isto a torna explicitamente um instrumento cultural, que deve ser reconhecida de forma igualmente explícita. O fenômeno de "Dallas" é instrutivo: primeiro, esta novela é praticamente internacional e transcultural, no que diz respeito a todos os países já industrializados. É tão popular na África do Sul quanto na classe média da América e consegue até atrair uma audiência demasiadamente grande para agradar os gurus da cultura francesa, motivando assim os franceses, na moda típica gaulesa, para criar sua própria versão mais "francesa" da série.

No entanto, estas são pequenas variações nas transferências da cultura tecnológica, uma vez que a maioria das culturas de alta tecnologia já são altamente "ocidentalizadas" (o Japão talvez seja o contraexemplo mais enigmático e interessante para uma afirmação muito grande sobre a aculturação neste nível.) A transferência de tecnologia-cultura no contexto de culturas que rejeitam firmemente muitos valores ocidentais se torna um problema mais sério.

Os países islâmicos são especialmente interessantes a este respeito. Por um lado, a maioria desses países está em fase de desenvolvimento médio e está se esforçando para a modernização tecnológica. Por outro lado, elementos culturais cruciais estão em conflito com os do Ocidente. O papel e a posição das mulheres são particularmente sensíveis e dizem respeito imediatamente à programação internacionalmente disponível (via satélite). O papel da privatização, purdah, e outros papéis importantes para as mulheres em contextos muçulmanos resistem às transferências culturais através da televisão? Esta é uma questão altamente debatida no Paquistão, por exemplo. Richard Reeves, em um de seus mais fascinantes e perceptivos diários no New Yorker, considerou o Paquistão um país comprometido com a modernização e a islamização. Através desta dupla meta, muitas vezes crucial, estavam as atitudes tradicionais em relação às mulheres. Talvez os pontos de vista do falecido General Zia, quando perguntado o que ele não queria com a modernização, respondessem: "O que não queremos é que nossas mulheres sejam forçadas a sair de sua privacidade, isso é o 
que não queremos." ${ }^{14}$ Quando questionado sobre o papel das mulheres em uma sociedade modernizada, Zia continuou dizendo: “Temos mulheres engenheiras. O Islã dita que as mulheres não podem ser deixadas fora do mainstream... Mas não vamos forçar nossas mulheres para fora às ruas. Encorajamos as mulheres a serem ativas dentro dos parâmetros do Islã." ${ }^{15}$ Zia ecoava os sentimentos de muitos dos elementos mais conservadores dentro da própria sociedade. Reeves observou que mesmo o diagnóstico médico em muitas áreas rurais permitia apenas que os homens relatassem os sintomas de suas esposas, sem permitir que nenhum médico masculino tivesse contato com a mulher enferma. Outro funcionário chegou mesmo a afirmar que uma razão subjacente à suspensão do anterior Presidente Bhutto estava relacionada com esse valor tradicional: "Por que Bhutto foi realmente enforcado?... Porque ele criou mulheres muito altas". ${ }^{16}$ É claro, mais tarde, o Paquistão viria a ser o primeiro país com uma mulher primeiro-ministro (Sra. Bhutto). E enquanto ela usa roupas tradicionais, o véu da purdah saiu de moda e o que se usa agora são roupas mais modernas. Mas o atual avivamento do fundamentalismo islâmico é o indicador da resistência contracultural a tais transferências.

Não estou aqui sugerindo que "novelas" e outros programas de televisão populares são um resultado cultural necessário da tecnologia de televisão. Embora possam ser ácidos para certos tipos de puritanismo cultural, a novela como tal não está em questão. $\mathrm{O}$ que está em jogo é uma questão cultural mais profunda: o pluralismo da transculturalidade, que constitui a não neutralidade última da cultura televisiva. Voltarei a esse tema em outro contexto.

\section{C. "Controlando" a tecnologia}

Agora já foi delineada a conjuntura em que a pergunta popular sobre o controle da tecnologia pode ser colocada ou, melhor, reformulada. Colocando a tecnologia dentro de um contexto cultural, as duas dimensões da ambiguidade estrutural essencial da tecnologia podem ser reaproximadas. Ao nível de uma fenomenologia, parte dessa ambiguidade essencial já era vista. A dupla ambiguidade de (a) qualquer artefato tecnológico que pode ser colocado em múltiplos contextos de uso, equilibrado por $(b)$ qualquer intenção tecnológica que pode

14 Richard Reeves no The New Yorker, 01/10/1984, p. 50.

15 Ibid., p. 68.

16 Ibid., p. 51. 
ser preenchida por uma gama de tecnologias possíveis, introduz certa indeterminação a todas as direções humano-tecnológicas.

Além disso, ao nível fenomenológico, esta ambiguidade estruturada foi obtida independentemente da simplicidade ou complexidade da tecnologia, pelo menos como possibilidade humana. As torres medievais do castelo que já foram usadas como escadas às ameias posteriormente foram mais frequentemente utilizadas para servirem de depósitos ou latrina. Da mesma forma, nos debates recentes sobre as usinas nucleares, veem-se abandonos que levam à conversão ou ao estabelecimento dos maiores "museus" do mundo de tecnologias abandonadas. O outro lado da ambiguidade em que muitas tecnologias diferentes podem servir para os mesmos propósitos inspira e extrapola a corrida armamentista com armas ilimitadas imaginadas para as variedades humanas de destruição. A gama infinita de possibilidades aqui, infelizmente, alimenta a demanda praticamente inesgotável por novos programas militares-industriais.

Ao nível de uma hermenêutica cultural, este problema torna-se mais complexo, mas não sem o aparecimento de padrões. Na medida em que as tecnologias são instrumentos culturais e na medida em que são vistos como especificamente incorporados nas matrizes culturais, também começam a ser reveladas formas mais elevadas de cultura-tecnologia. Este fenômeno origina a presente questão sobre o "controle" da tecnologia.

Dada esta dupla complexidade, agora vista igualmente nos níveis fenomenológico e hermenêutico, a primeira resposta à questão de se a tecnologia pode ser controlada deve ser uma resposta negativa. A razão pela qual a tecnologia não pode ser "controlada" se deve ao fato da questão ser colocada de maneira equivocada. Ou pressupõe que as tecnologias são "meramente" instrumentais e, portanto, neutras, ou pressupõe que as tecnologias são totalmente determinadoras e, portanto, incontroláveis. Ambas as extremidades estão presentes nos debates atuais, mas ambas não contemplam o aspecto das relatividades humano-tecnologia e a cultura-tecnologia que reconstituiriam o debate.

Reformular a questão, agora no contexto da integração das tecnologias nas culturas, é ver que a questão do controle da tecnologia é análoga à questão: as culturas podem ser "controladas"? Esta reformulação revela o grau de complexidade necessário para a sua resposta. Poucas, exceto pelos megalomaníacos historicamente associados a resultados desastrosos, responderiam rapidamente positivamente a essa reformulação. Há mesmo uma boa razão para ver a preocupação do século XX pelo "controle" da tecnologia como o equivalente 
contemporâneo da obsessão do século XIX pelo "controle" da natureza. Nenhuma das perguntas, em minha opinião, é posta corretamente.

Retrospectivamente, mesmo nos casos mais simples, a questão do "controle" permanece mal colocada. Na loja de ferramentas, por um momento, substituímos o martelo heideggeriano por um torno, na medida em que o contexto ferramenta-humano é constituído como uma relação em que o usuário "controla" o cinzel, é o torno e o seu giro do cabeçote que fornece o contexto que definem os movimentos do usuário junto ao torno. Entrar em qualquer relação humano-tecnologia é sempre tanto para "controlar" quanto para "ser controlado". Uma vez que a noção de tecnologia no conjunto é levantada, particularmente na medida em que as tecnologias estão inseridas em complexos culturais, a questão do "controle" torna-se ainda mais sem sentido.

Trajetórias do desenvolvimento tais como a ampliação na ótica tem sido descritas como resultado de "intencionalidades" instrumentais. Ainda que no nível hermenêutico, também se pode notar que tais trajetórias nem sempre foram seguidas, dependendo do campo cultural mais amplo e mais complexo. A própria questão do controle toma sua forma junto a uma metafísica implícita, porém ultrapassada do determinismo. Assim como o debate do determinismo social versus o determinismo cultural é rejeitado aqui, então se deve ter conta que as tecnologias em uso não determinam, como tal.

No entanto, elas não são simplesmente neutras. As tecnologias, ao fornecerem uma estrutura para a ação, formam intencionalidades e inclinações junto às quais os padrões de uso tomam a forma dominante. Isso também pode ser visto no nível fenomenológico. Em uma atividade altamente familiar aos filósofos, observe os seguintes exemplos de tal "inclinação" nos usos variantes de três instrumentos de composição: a caneta de tinteiro, uma máquina de escrever e o processador de texto.

Neste exemplo, considere ( $a$ ) a atividade de edição, $(b)$ a velocidade da composição e $(c)$ a sutileza de estilo. Eu fiquei familiarizado com o uso da antiquada caneta quando meus dois filhos mais novos entraram em uma escola primária em Paris. A arte de escrever com canetas de penas foi ensinada a eles como o fora para meus avós, com cópia cuidadosa, instrução estrita e papel alinhado. Fiquei fascinado pela uniformidade do resultado. Depois que as crianças iam para a cama, eu também comecei a escrever com a caneta. A princípio, o que se destaca é a lentidão do processo de escrita (eu compus, em seguida, com uma máquina de escrever). Mas eu também descobri que, enquanto os processos 
mentais de alguém acontecem bem à frente do tempo da escrita real, a edição (mental) poderia tomar forma enquanto o processo estava em curso. Pode-se formular ou reformular uma frase várias vezes antes da conclusão. Sendo que reescrever era realmente doloroso, e fosse o objeto para ser descrito em letra composta, isso demandaria recomeçar sempre, desde que não houvesse nenhuma simples rasura.

Depois de alguma experiência, acompanhada por outro fenômeno, o fascínio com a aparência real da escrita, cuja rotulação poderia ser muito bonita, pois as curvas e os diversos traços poderiam alcançar a qualidade estética, redescobri a "arte" desta escrita. Eu não poderia afirmar que o uso da pena e do tinteiro "determinou" que eu escreva no estilo das belleslettres, mas a propensão ou inclinação certamente lá estavam.

Contrastando essa experiência de escrever com a da máquina de escrever (que era manual), podia-se ver que a proporção da velocidade do pensamento para a aparência em si das palavras no papel foi consideravelmente reduzida. Já a edição, ainda que dolorosa, não era tanto assim. E uma abordagem cortar/colar foi muito boa para os rascunhos. Não era necessário estar preocupado com a caligrafia do texto, já que isso era predeterminado pela máquina. Novamente, o estilo não estava sendo "determinado", embora a beleza das letras fosse agora eliminada e, assim, junto com ela, uma das características das belas letras. Dada a velocidade da composição, pode-se argumentar que um padrão de estilo mais jornalístico ou mais próximo à fala era o mais provável "centro gravitacional" para esse modo de composição. Ainda assim, é na melhor das hipóteses uma ligeira inclinação e poderia ser tão variada quanto a autodisciplina do escritor.

O processador eletrônico introduz uma estrutura instrumental e um conjunto de possibilidades diferentes e é agora o instrumento favorito de muitos acadêmicos. O que se destaca aqui é a transformação do processo de edição. Se tornar muito fácil do que com as tecnologias predecessoras, dada a possibilidade de reescrever e de mover blocos inteiros de sentenças ao longo do texto. Ainda que a velocidade da composição seja apenas pouco aumentada em relação às máquinas de escrever elétricas, ela é ligeiramente aumentada com o eletrônico em comparação com o teclado elétrico de máquinas de escrever mais antigas.

Precisamente porque o processo de edição é fácil, a composição agora oferece uma tentação focal. A facilidade de reescrever torna-se uma maneira de ver todo o projeto como mais maleável e, portanto, não permanente. Michael Heim aponta algo semelhante em seu Electric Language. Ele argumenta que o 
computador implica uma noção totalmente diferente do trabalho, da composição e da linguagem em uma revolução que não é diferente do movimento da cultura oral para a alfabetizada. O processamento de texto também encoraja o reaparecimento do que eu chamo de "tomo germânico", o altamente comentado e documentado livro erudito agora tornado mais fácil pelos vários programas de rodapé favorecidos por estudiosos já inclinados a isso. Bruce Lee, editor da William Morrow and Co., descreveu na Newsday, 29 de janeiro de 1989, que "cerca de $80 \%$ do tempo é provável que eu receba um manuscrito que é mais longo do que o comprimento contratado do livro. De fato, desde que os processadores de texto surgiram, manuscritos de livro dobraram em comprimento... Uma razão é a facilidade em se fazer anotações.")

Em nenhuma destas variações a tecnologia "determina” o estilo ou o tipo de composição, mas ela "inclina” para algumas possibilidades simplesmente em virtude de qual parte da experiência escrita é facilitada e qual se torna difícil (aqui retorna a estrutura ampliação/redução). Projetam-se tais inclinações dentre muitos usuários, o resultado fica próximo de ser previsível no nível social em larga escala.

O que situa este fenômeno completamente, contudo, é o contexto cultural. Modos de escrita isolados e especializados são os que resistem a todas essas inovações tecnológicas, a cópia das Torás nas tradições ortodoxas, por exemplo, ainda é feita em pergaminho e com caneta de pena. Ironicamente, enquanto as subculturas religiosas se mantêm vivas, alguns de seus praticantes hoje operam as mais altas tecnologias de imagem, computação e negócios eletrônicos na cidade de Nova Iorque, fato que aponta para o ecletismo tecnológico, pelo menos! No entanto, a diferença entre o pergaminho e o computador não é sempre confortável, mesmo dentro do ecletismo:

Quando o projeto para computadorizar o comentário sobre a lei judaica estava em andamento na Bar Ilan University em Israel, os programadores se depararam com um enigma. As leis judaicas proíbem que o nome de Deus, uma vez escrito, seja apagado ou que o papel em que foi escrito seja destruído. Poderia o nome de Deus ser apagado do monitor de vídeo, dos discos, das fitas? Os rabinos ponderaram a questão dos programadores e finalmente determinaram que esta mídia não era considerada escrita; eles poderiam ser apagados. ${ }^{17}$

17 HEIM, Michael. Electric Language: A Philosophical Study of Word Processing. New Haven: Yale University Press, 1987, p. 192. 
Se a questão de "controlar" a tecnologia é mal concebida, como eu tenho argumentado aqui, isto não significa ignorar os tópicos cruciais apontados naqueles debates. Existem tópicos sérios sobre se tecnologias devem ou não devem ser desenvolvidas (existe uma questão política sobre o desenvolvimento tecnológico implicada aqui). O tipo e o grau de avaliação de tecnologia atualmente praticados são claramente demasiado mínimo e primitivo, bem como muito controlado por precisamente aqueles que precisam ser "controlados". Se o exemplo de avaliação de risco é ele próprio o maior exemplo de pensamento quantitativo, existe aqui uma forma mais nova e mais sutil de conflito de interesses regulatórios. As próprias agências, cujas práticas devem ser avaliadas, insistem em que os termos de avaliação sejam tecnocráticos em sua forma. Por sua vez, o estilo de avaliação torna-se modelado sobre o mais quantitativo da variação teórica ética e política do utilitarismo.

Há questões cruciais relacionadas com o debate sobre "controle" que gira em torno de conflitos entre a conservação dos habitats naturais (florestas tropicais, ambientes oceânicos, etc.) e o desenvolvimento de recursos, quais as formas de tecnologia precisam de subsídio (alternativas de produção de energia), tecnologias correlatas ao trabalho (intensivo versus não intensivo, particularmente entre países desenvolvidos e em desenvolvimento), etc. Entretanto, em um sentido profundo, embora essas questões sejam cruciais, elas também são primordialmente políticas em urgência e forma e situam-se dentro do campo cultural mais amplo. Na medida em que tal é o caso, esses debates são medianos e devem engajar uma cidadania, esperançosamente, bem instruída e informada, nem tecnologicamente analfabeta e nem hipnotizada pela mistificação da "expertise". No entanto, nenhuma dessas questões de nível intermediário atinge diretamente os valores culturais mais profundos e amplos que situam todo o campo dos debates.

Poderia gostar-se de dizer que estes valores culturais são questões filosóficas, o que de fato são, mas precisamente porque são, são também as menos suscetíveis de "controle". Pode ser fácil para o filósofo ver que uma metafísica da natureza como bem de consumo é uma metafísica pobre para melhorar a conservação até mesmo dos “museus sobre a natureza", mas não é uma questão fácil mudar a sensibilidade cultural difundida ao longo de toda uma tradição.

A crítica da dominação ocidental da natureza por meio da ciência já tem sido um longo tema da crítica filosófica, recentemente incorporado pelo criticismo 
feminista deste fenômeno. ${ }^{18}$ Precisamente porque os papéis macho/fêmea são parte da estrutura cultural, profundamente entrincheirados e há muito estabelecido, é difícil mudar estes padrões. Depois de décadas de ataque, permanece que, sociologicamente, as ciências naturais, junto com a engenharia, continuam predominantemente províncias masculinas, resistentes às mudanças de recrutamento e ainda mais resistentes às profundas mudanças conceituais mesmo em relação à triste história da metáfora da violação ou da sedução da "amante Natureza” (frases que ocorreram em um dos discursos de aceitação do prêmio Nobel do ano passado!). Parece mais fácil acomodar homens de culturas ainda mais dominadas pelos homens do que os nossos dentro desse quadro institucional (isso faz parte da história de sucesso em relação a muitos novos emigrantes) do que atrair ou acomodar mulheres nesse mesmo estabelecimento.

\section{Incorporação da cultura-tecnologia como multiestabilidade}

A ambiguidade estruturada, porém essencial, da tecnologia foi trazida à tona e, com ela, o fenômeno de variantes culturais incorporadas. Com este impulso positivo de análise, eu também tentei mudar as perspectivas e a ordem do dia em alguns debates. Este foi o aspecto negativamente crítico da análise. Rejeitar a forma como questões críticas foram levantadas sobre a tecnologia, embora valiosa, deixa em suspensão a possibilidade de uma contratese positiva. Tal tese é necessariamente mais especulativa e teórica do que precedeu esta conjuntura, mas a base essa tese esteve implícita todo o tempo. Posso afirmar a tese de forma abstrata: negativamente, tenho argumentado que não existe uma trajetória única ou unificada para a "Tecnologia" (com o "T" maiúsculo), que as tecnologias nesse sentido não são "autônomas", e que o próprio conceito de "controle" é mal colocado. Positivamente, tenho argumentado que as tecnologias são não neutras e, essencialmente, estruturalmente, ambíguas. Na relação com humanos e humanos em cultura, as tecnologias transformam a experiência e suas variações. Além disso, tenho argumentado que, no nível complexo de uma hermenêutica cultural, as tecnologias podem ser variantemente incorporadas, a "mesma" tecnologia em outro contexto cultural se torna uma tecnologia "diferente".

18 Sobre isto, ver especialmente o livro de HARDING, Sandra. The Science Question in Feminism.Ithaca: Cornell University Press, 1986. 
Agora é tempo de colocar um nome sobre aquelas estruturas ambíguas e descrever o que eu tomo como sendo sua forma ou formas. O nome, seguindo a estratégia perceptualista que eu escolhi para esta estrutura cultura-tecnologia é multiestabilidade. Seu modelo vem diretamente da fenomenologia da percepção e da polimorfia que a percepção evidencia. ${ }^{19}$

O exemplo perceptual mais simples que eu uso frequentemente para ilustrar esta polimorfia é a desconstrução fenomenológica do famoso Cubo de $\mathrm{Ne}$ cker favorecido pelas psicologias da percepção (Figura 7). Merleau-Ponty também analisou esta ambiguidade do cubo de Necker no seu livro Fenomenologia da Percepção. Minha análise, contudo, é mais desconstrutiva no que as variações vêm a ser muito mais extensas e variáveis do que aquelas permitidas por Merleau-Ponty.

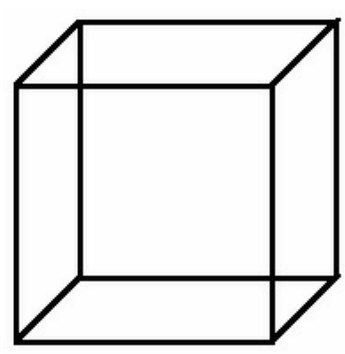

Primeiramente, o cubo Necker é um objeto perceptivo ambíguo, essencialmente biestável, no qual (a) a parte mais alta da figura é vista como o canto distante de sua face superior, mas através de um interruptor gestáltico "espontâneo", (b) a parte superior é vista como o canto próximo da sua face superior, com uma segunda estabilidade tridimensional. Essas duas variações podem alternar entre si no olhar do espectador, num conjunto de alternâncias distintas umas das outras, exclusivas, porém relacionadas como aparições tridimensionais de um cubo.

Um exemplo similar de um interruptor gestalt de multiestabilidades tem sido usado por Thomas Kuhn, em A Estrutura das Revoluções Científicas, para descrever o fenômeno de mudanças de paradigma em modos de visão científica. Mas Kuhn, como na maioria das psicologias, retém apenas o exemplo de uma biestabilidade como suficiente ou sugestivo para tais mudanças de visão.

A fenomenologia vai muito mais longe à análise da multiestabilidade perceptiva. Seu objetivo é examinar as variações exaustivamente para mostrar

19 Ver meu livro anterior Experimental Phenomenology.Albany: SUNY Press, reprinted 1986. Lá, eu esboço uma teoria muito mais completa da multiestabilidade visual da qual aqui derivei apenas alguns exemplos sugestivos. 
características estruturais ou invariantes. Com essa busca de estruturas-possibilidades em mente, tal análise desconstrói ainda mais tais objetos multiestáveis. Só tomarei parte dessa desconstrução aqui para definir o quadro de estruturas multiestáveis, neste caso, dentro da percepção visual.

Para fazer isso, empregarei um dispositivo cultural para fazer as variações aparecerem dentro de um contexto perceptual ao mesmo tempo sensorial (microperceptual) e ainda situado por uma "cultura" (macroperceptual) em uma história. Suponha que, em vez de tomar o objeto como o desenho já familiar e sedimentado de um cubo, eu lhe diga que é realmente uma representação de um inseto estranho em um buraco. (Ver a Figura 8). O contorno de seis lados em torno do inseto é o contorno do buraco. O paralelogramo no centro deste desenho é o corpo do inseto; as linhas remanescentes que se projetam para fora do paralelogramo são as pernas do inseto. Normalmente, após um par de tentativas, esta nova gestalt da figura ocorre facilmente e pode ser vista como uma variação bidimensional sobre o desenho ambíguo.
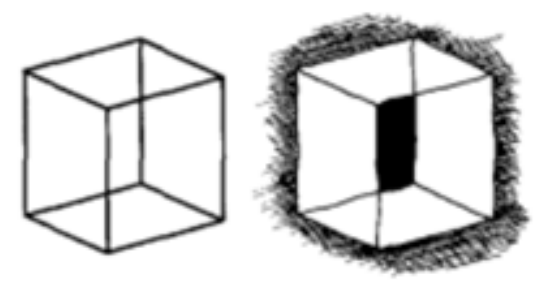

Nem uma desconstrução fenomenológica permanece satisfeita com esta triestabilidade recentemente estabelecida sobre o que antes era tomado como uma figura biestável. Uma nova micro e macroconfiguração através de outra história pode estabelecer uma segunda variante tridimensional alternativa e exclusiva da variação "cubo". Neste caso, o cubo deve ser tomado como uma "gema" curiosamente cortada, na qual o paralelogramo é a faceta da pedra transparente mais próxima do visualizador (veja a Figura 9). O contorno de seis lados é o contorno da gema, mas agora as formas em torno do paralelogramo atingindo os limites externos da gema são as facetas, em grau tridimensional para o limite da borda mais distante. Aqui, então, é uma segunda forma tridimensional, não consoante com a forma do cubo em absoluto, mas claramente tridimensional. 


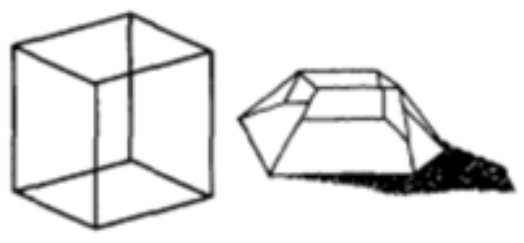

Até agora, os "segredos" da desconstrução começam a mostrar-se. Se uma reversão do cubo é possível, não deveria uma reversão da gema também ser possível? Isso é facilmente estabelecido em um novo conto: a gema está agora sendo olhada de baixo; a faceta do paralelogramo central é considerada "mais distante" do espectador do que o contorno delimitado da gema, que é considerado "mais próximo". Assim, uma variante de reversão na segunda forma tridimensional é atingida.

Tal multiestabilidade perceptiva complexa é um dos resultados de uma fenomenologia da percepção que tem implicações consideráveis para qualquer psicologia da visão, embora raramente seguida. Minha sugestão aqui é que essa multiestabilidade também pode ser vista nas relações humano-tecnologias e ainda mais fortemente nas complexidades da gestalt tecnologia-cultura. Para cimentar este ponto, voltarei aos exemplos de navegação que segui e, ao mesmo tempo, desenvolver uma variação histórico-antropológica sobre as técnicas de navegação e extrapolar imaginativamente o desenvolvimento tecnológico.

Nós notamos logo cedo como a navegação ocidental tomou sua forma numa hermenêutica matemática e num sistema instrumento-incorporado por meio dos quais sua forma dominante empregada naquilo de "ler" posições existenciais.

Atualizando essa trajetória, pode-se ver que, no final do século XX, tanto a hermenêutica matemática quanto o uso da instrumentação se desenvolveram ainda mais. O submarino nuclear carrega com ele a maquinaria de navegação que tem mostras complexas de leituras digitais. Estas são aprimoradas por instrumentos que, por sua vez, estão relacionados hermeneuticamente com as posições dos gráficos. Na ação, o navegante, com poucas exceções, não "percebe" onde ele está até quanto "lê" onde de fato se encontra em virtude do aprendizado do quadro instrumental, que se tornou sedimentado e familiar em uma práxis detalhada. 
Os conjuntos contrastantes de práxis de navegação, que são uma estabilidade cultural diferente, são aqueles desenvolvidos pelas escolas relacionadas a antigos navegadores do Pacífico Sul. Historicamente, começando bem antes das viagens de Leif Ericson e séculos antes de Colombo, a maioria das principais ilhas do Pacífico tinha sido habitada, e foram realizadas viagens de interconexão entre aquelas ilhas distantes. A dificuldade desta tarefa de navegação era consideravelmente mais complexa do que aquela que os navegadores ocidentais enfrentavam e em que as massas de terra eram muito menores e, consequentemente, mais difícil de encontrar, e as distâncias e espaçamento dentro do Pacífico eram maiores. Contudo, esses navegadores primitivos ligavam todo o Pacífico e povoavam até mesmo ilhas isoladas, como a Ilha de Páscoa e o Havaí.

Com respeito à tecnologia, os primeiros exploradores europeus notaram com espanto tanto o tamanho e a sofisticação, mas especialmente as velocidades dos viajantes do Pacífico. Os multicascos, que em versões de alta tecnologia já quebraram praticamente todos os registros de navegação e que têm velocidades que correspondem a muitas embarcações, foram altamente desenvolvidos e capazes de longas viagens oceânicas com um número considerável de passageiros e os suprimentos para sustentá-los durante estas longas travessias. Essas embarcações poderiam facilmente ultrapassar e superar a lenta, porém pesada embarcação europeia que transportava cargas da mesma época. (Continua a ser uma anomalia interessante na história da tecnologia da vela que, embora os europeus reconhecessem a tecnologia superior, nunca a adaptaram aos seus próprios propósitos: uma tecnologia que não se transferiu até os tempos contemporâneos que acabamos de mencionar).

O que não foi tecnologizado, no entanto, foi a práxis de navegação do polinésio e da maioria dos outros navegadores do Pacífico Sul. Instrumentos não foram usados, um fato difícil de aceitar por intérpretes ocidentais até tempos muito recentes. Quando eu estive em Taiti em 1985, descobri um tratado sobre a vela, indicando que, até meados dos anos cinquenta, os intérpretes ocidentais estavam "insistindo" em que os instrumentos deviam ter sido usados. O exemplo dado foi o de uma concha com dois furos perfurados na parte superior. $\mathrm{O}$ pesquisador descobriu que os sons que o vento fazia ao atravessar esses furos variavam com a velocidade, e assim ele concluiu que este deve ter sido um indicador de vento primitivo. Na verdade, era simplesmente o pendente de um colar de conchas; os buracos eram para o cabo. 
Em vez disso, o sistema de navegação do Pacífico poderia ser chamado de um sistema sofisticado e matizado merleau-pontiano de micro/macropercepção. Primeiro, nele a posição real do corpo do navegante torna-se a constante fixa: a bordo, não se disse que alguém estava indo para Poluwat; um deles disse: "Poluwat se aproxima". Em todo o quadro descritivo, a relatividade da posição corporal em relação aos pontos de referência (raramente abstrata, quase sempre ilhas aprendidas, fenômenos de onda, estrelas, etc.) foi consistentemente mantida. Essa relatividade perceptiva é perfeitamente consistente e precisamente descritiva. Embarcado, uma ilha cresce cada vez mais, já que parece ter que pressupor alguma posição mais ideal ou não incorporada a partir da qual se diz "Estou me aproximando, Poluwat", que é a posição tão familiar para nós que a tomamos como certa. Da mesma forma, pontos de referência, a partir da posição do navegador, movem-se. Assim, havia uma linguagem descritiva para as formas como as ilhas se moviam em relação umas às outras e para os caminhos das estrelas e os outros fenômenos naturais que eram perceptualmente "lidos" como o sistema de referências de navegação.

Ilhas ou massas de terra foram descobertas por outros complexos naturais significativos percebidos. Muito antes de avistar-se uma ilha real, sua presença poderia ser detectada por $(a)$ nuvens estacionárias sobre as ilhas em contraste com as nuvens movendo-se simultaneamente movidas pelos ventos alísios; (b) pássaros que voltam ao poleiro à noite, com diferentes espécies indicando, através das suas distâncias desde a ilha, as distâncias aproximadas para a terra; (c) refração de padrões de marulho que "se curvam" quando se aproximam de uma massa terrestre. E uma infinidade de outros fenômenos bem conhecidos, mas difíceis de aprender.

Uma das "leituras" perceptivas mais sutis tinha a ver com padrões de ondas. Direções de curso eram tomadas a partir do ângulo da embarcação para os padrões de marulho dominante, e um curso poderia ser mantido durante o dia e a noite pela sensação da embarcação para com o marulho. Mesmo em tempestades locais, este "acorde" de marulho dominante poderia ser detectado na presença de mares localmente confusos.

À noite, em vez de uma bússola, trilhas de estrelas foram anotadas e organizadas hermeneuticamente. $\mathrm{O}$ sistema de referências foi dinâmico no sentido de que a Estrela Polar fixa não é visível a partir de áreas subequatoriais em grande parte do Pacífico. Em vez disso, os paralelos e as configurações de estrelas em 
ascensão foram seguidos e incorporados em canções que gravavam mnemonicamente as fórmulas para as diferentes viagens do repertório. ${ }^{20}$

Aqui, então, havia um sistema de navegação altamente complexo, mas não instrumentalmente mediado, pragmático e comprovadamente bem-sucedido, de forma relativista, usando constantes dinâmicas e perceptivamente hermenêuticas. É mesmo anacrônico chamar isso de processo de "leitura", já que os navegadores eram pré-letrados. O sistema era praticamente não matemático, exceto para a contagem diurna e noturna, mas claramente nenhuma geometria relacionada ao número foi usada. O sistema manteve-se culturalmente estável, até mesmo em forma vestigial, até o presente (viagens usando o sistema foram reproduzidas por havaianos estimulados pelos antropólogos que descobriram os sistemas, mais notavelmente David Lewis da Australian National University). ${ }^{21}$ Era uma contraposição à navegação ocidental.

Novamente, o propósito aqui, apesar da grande admiração que tenho por este sistema, um sistema que não aprendi, exceto parcialmente e em minhas próprias práticas de navegação, não é romantizar a navegação polinésia. É apontar uma conquista cultural não ocidental, mas sofisticada que, enquanto permaneceu isolada, manteve-se um modo prático e bem-sucedido de orientação de longo alcance e que contrasta em seus elementos-chave com o nosso sistema matematicamente mediado por instrumentos, igualmente estável e bem-sucedido. Pretendo com isto exemplificar um paralelo ao da multiestabilidade do cubo, neste caso como duas variantes do desejo humano de uma orientação de longa distância através de mares que se estendem para além dos horizontes imediatos. Trata-se de um exemplo de multiestabilidades culturais diferentes.

Histórica e antropologicamente, esses dois sistemas em épocas mais antigas poderiam ser vistos como dois sistemas equivalentes, um "tecnológico", o outro não. Mas, existencialmente e em relação à percepção e à matriz cultura-tecnologia, pode-se imaginar uma trajetória tecnológica que se encaixaria na práxis polinésia. Na medida em que o sistema é "merleau-pontiano" em virtude da posição real do corpo em relação aos referentes, a incorporação tecnológica

20 Práticas observacionais e instrumentais da astronomia antiga e navegação estão particularmente bem descritas em AVENI, A. T. “Tropical Archeoastronomy”, Science, 10 de julho de 1981, Vol. 213, p. 4505. Arqueoastronomia é uma das muitas disciplinas híbridas surgindo a partir dos interesses da ciência e das humanidades nas práxis passadas.

21 David Lewis, ele próprio um navegador fervoroso, tornou os modos de navegação do Pacífico Sul conhecidos através do seu We the Navigators (Honollulu: University of Hawaii Press, 1972) e depois de um modo mais popular na National Geographic, bem como em reproduzir as viagens em televisão pública. Um estudo muito detalhado da navegação puluwateana foi feita por Thomas Gladwin em East is a Big Bird (Cambridge: Harvard University Press, 1970). 
de tal sistema dependeria pesadamente das relações de incorporação para realçar, estender ou ampliar a percepção sensório-corporal.

Tal sistema, por exemplo, seria auxiliado por instrumentos que permitem ao navegador ver através de nevoeiros ou situações obscuras. As telas em alguns aviões, que mostram as configurações da pista para o piloto sentado, são exemplos atuais contemporâneos de tal instrumentação. Exibições visuais que fazem a mesma coisa a partir da "posição de gráfico", frequentemente favorecida em nossos próprios sistemas, não. Por exemplo, no sistema LORAN (Long Range Navigation), um sistema de sinal de radar popular entre os marinheiros, os últimos dispositivos totalmente matematicamente hermenêuticos mostrando posições por meio de números em uma tela de vídeo foram recentemente aprimorados por meio de displays mostrando um gráfico com um ponto de luz indicando a posição do navio no gráfico. Este último desenvolvimento não só tem a vantagem da instantaneidade da gestalt da visão, como substitui um passo no processo de leitura: a transferência de informação digital para informações analógicas em um gráfico. Mas para o nosso sistema polinésio, esta versão de um processo hermenêutico perceptivo deve fazer a sua referência à posição corporal real do navegador. Teria, portanto, de contar com um visor "lateral" em vez de um visor superior.

Poderíamos imaginar tais instrumentos e, na verdade, gostaria de tê-los: por exemplo, um localizador de profundidade que mostraria em três dimensões, perceptivamente, a configuração de fundos rasos em relação à posição real do barco; o visor de nevoeiro-difuso mencionado anteriormente; ou, extrapolando ainda mais imaginativamente, uma exibição sobre o horizonte das ilhas próximas. Em suma, o sistema polinésio poderia ter uma incorporação instrumental, uma forma de realização que se relaciona com seu foco perceptivo e relatividade.

Isso seria, em certo sentido, uma tecnologia diferente, ou, pelo menos, uma tecnologia com uma trajetória diferente, uma tecnologia apropriada ao sistema e à estrutura da estabilidade cultural polinésia. Mas, neste momento, algo parece "estranho" precisamente porque, uma vez que descobrimos a multiestabilidade, já estamos em uma posição que transforma a multiestabilidade em si.

A transformação pode ser sugerida voltando ao desenvolvimento desejado de equipamentos de navegação imaginados. Se um sistema é bom, por que não dois? Ou, melhor, por que não ter sistemas redundantes e sobrepostos? Por exemplo, um dos problemas que nossas próprias traduções hermenêuticas duplicadas enfrentam entre exposições de gráfico e posições incorporadas reais 
têm a ver com a correlação de marcos. De uma posição incorporada, aquela espiral está à esquerda da torre de rádio. Mas são estes os dois pontos indicados no gráfico, ou estou em outro lugar com uma marcação semelhante? Já o display duplicado em um console, antes de um display apenas, pode ser ainda melhor do que um ou outro. Mas aparte dos instrumentos imaginados que poderiam melhorar a situação, há um sentido mais profundo em ver que esta duplicação de sistemas é precisamente onde nós estamos!

Nomear um fenômeno multiestável já é reconhecê-lo por sua ambiguidade e múltiplas dimensões. Retorne ao desenho de cubo/inseto/gema: uma vez que o espectador é capaz de agarrar facilmente e com sucesso cada uma das gestalts das variantes e, mais, discernir a multiplicação irreversível de uma trajetória em tal desconstrução com sua relação aos fenômenos relacionados, o mesmo espectador não pode simplesmente retornar para a visualização ingênua previamente tomada como literal. Aqui há uma mudança irreversível de sentido que transforma o Jardim da percepção ingênua em outra coisa. Se o mesmo se aplica às matrizes de cultura-tecnologia, deve haver, no entanto, uma transformação semelhante desta multiestabilidade mais complexa. Isso também é um fenômeno que está diante de nossos olhos, mas que precisa de algo de uma hermenêutica fenomenológica para tornar-se aparente.

Na maior altitude, se a cultura tecnológica é uma forma de ver, então se torna importante que possamos descrever qual é a forma dessa visão. Mas, ao mesmo tempo, eu tenho argumentado que a cultura tecnológica não é simplesmente uma coisa. Nem é uniforme e nem tem sua progressão alcançada ao longo do globo, que é o que seus detratores temem ou o que seus proponentes almejam. Se se deseja também uma forma de ver ou implicar a não neutralidade tecnológica, como também já discuti, então é igualmente importante que as seletividades resultantes sejam identificadas.

Para iniciar este processo, voltarei, de forma mais especulativa, ao fenômeno da transferência de tecnologia como relacionado aos tipos de culturas que observamos.

\section{E. As variedades da experiência tecnológica}

A presente marcha da cultura de alta tecnologia através do globo é um fato sobre o qual os críticos e os defensores concordariam. Um resultado desta marcha é a decrescente habilidade das culturas tradicionais ("primitivas") a resistir 
a mudanças radicais ou a uma possível extinção cultural. Estas culturas são as mais vulneráveis ao impacto da tecnologização.

Embora seja lamentável que essa classe especial de culturas tradicionais esteja desaparecendo, os exemplos anteriores também mostraram que existe uma gama média bastante grande de culturas que fizeram adaptações de compromisso, com as tecnologias modernas afetando apenas partes selecionadas (embora raramente partes "escolhidas", deve-se admitir) e deixando grandes aspectos dessas culturas intactas. Historicamente, tem ocorrido alguns casos em que se oferece resistência, ou se esquece ou se ignora os intercâmbios interculturais envolvendo tecnologias incorporadas. A recusa de incorporar relógios na cultura chinesa antes dos tempos modernos e o fracasso total em seguir a trajetória sugerida da construção naval de casco múltiplo pelo Ocidente são apenas dois exemplos predominantes.

O que estou sugerindo é uma categorização grosseira de respostas culturais a tecnologias levadas a cabo por fontes estrangeiras para grupos indígenas: (1) há o que eu chamarei de "monoculturas" dos tipos tradicionais, que virtualmente, qualquer que seja a resposta que eles apresentem, virtualmente sempre serão oprimidos pelo grupo que entra; (2) há adaptações intermediárias de compromisso que implicam o uso de tecnologias selecionadas na cultura indígena, ou essas tecnologias podem ser adaptadas a um novo contexto cultural ou apenas uma parte de seu papel anterior pode ser aceita; (3) há culturas que podem resistir com sucesso à maioria dos elementos das tecnologias do grupo de entrada, embora sejam raras as exceções à maioria das trocas culturais; e, finalmente, (4) há culturas que adotam, às vezes até mesmo com entusiasmo, o que há de novo no grupo de entrada e se modificam em alguma aproximação da forma cultural deste grupo.

O conjunto de exemplos anteriores insinuou cada uma dessas categorias. Se começarmos em ordem inversa, é claro que o Japão, em períodos históricos diferentes, exemplificou tanto a resistência (3) como a adaptação voluntária (4) à cultura de alta tecnologia e, na superfície, até mesmo muitos de seus acervos ocidentais. Mas é uma adaptação, já que os componentes da universidade e da indústria são bastante diferentes dos seus homólogos ocidentais (operando pela competição e intenso elitismo na universidade e pelo consenso corporativo e relações de grupo na indústria). Mas grande parte do setor privado continua sendo tradicionalmente japonês. Anteriormente, antes da abertura do país ao 
Ocidente, o Japão foi bem-sucedido por um longo tempo, em termos históricos, em resistir praticamente a toda influência ocidental significativa.

Ambos estes períodos, entretanto, são marcados por algum grau do chauvinismo cultural, um ingrediente, eu diria, essencial tanto à resistência quanto à plena aceitação das influências estrangeiras. Uma sociedade deve ter certeza de si mesma para rejeitar ou aceitar o que é genuinamente "outro" do que a si próprio. Essa característica certamente marcou o sentido japonês de cultura durante o período de resistência e, de maneira diferente, hoje.

$\mathrm{O}$ mesmo ingrediente pode ser visto em outro exemplo menos familiar para nós. Boorstein descreve que uma das proezas da navegação chinesa teria sido a descoberta, do ponto de vista chinês, da maior parte dos litorais até a própria porta da Europa, através de uma série de viagens marítimas cujo objetivo principal era simplesmente proclamar a superioridade de civilização chinesa.

Estas viagens ocorreram de 1405 a 1433, quando foram, tal como tantos reveses na história chinesa, simplesmente canceladas, e a China fechou-se para o mundo exterior por outro longo período de isolamento. Mas durante a vida do ambicioso Imperador Yung Lo, as expedições lideradas pelo eunuco Cheng Ho foram feitas para proclamar ao mundo a superioridade das realizações de Sua Majestade:

Estas expedições (1405-1433), as mais vastas até então vistas em nosso planeta, alistaram uns trinta e sete mil em suas tripulações, em flotilhas contando com trezentos e dezessete navios. Navios de tamanho variando entre os maiores, o navio do tesouro com nove mastros, com 444 pés de comprimento, com um raio de 180 pés, passando pelo navio dos cavalos, navio de abastecimento, navio de boleto, até os menores, o navio de combate, que contava com cinco mastros e media 180 por 68 pés. ${ }^{22}$

Se Colombo tivesse sido tão financiado! Ou enviado para o mar em navios tão grandes! Nossa própria história de meio século mais tarde poderia muito bem ter sido diferente. Seu navio principal, o Santa Maria, era menor que o menor navio de Ho. Da mesma forma, a tecnologia chinesa de construção naval era de um tipo superior para os tempos:

22 BOORSTEIN, 1985, p. 190. 
Os ocidentais também notaram a notável construção que impediu a água, em uma parte do casco, de inundar todo o navio. Anteparos, uma série de divisórias verticais que dividem a preensão do navio em compartimentos para impedir a propagação da inundação ou do fogo... Este projeto deu a força e a elasticidade que tornaram possível os navios de vários andares que deslumbraram os visitantes do exterior com sua galeria de popa alta pendendo, a partir do qual foi suspenso um leme gigantesco com uma lâmina de 450 metros quadrados... É claro, ele usou a bússola e talvez outros instrumentos direcionais, juntamente a elaboradas cartas de navegação mostrando rolamentos de bússola detalhada. ${ }^{23}$

Estas expedições chegaram a todo o Sudeste Asiático, toda a costa indiana, até o Golfo Pérsico, com base em notícias recentes. No Pacífico, as expedições visitaram Ryukyu, Brunei; e no Oceano Índico, Bornéu e Zanzibar. Mas o que era mais incomum estava na finalidade e no tipo de viagem que foram projetados, simplesmente proclamar a superioridade da nova dinastia de Ming como a cultura a mais elevada do mundo:

As viagens provaram que técnicas rituais e não-violentas de persuasão poderiam extrair tributos de estados remotos. Os chineses não iriam estabelecer suas próprias bases permanentes dentro dos estados tributários, mas sim esperavam transformar "o mundo inteiro" em admiradores voluntários do único centro da civilização. ${ }^{24}$

É uma pena que essa generosidade, mesmo se motivada pelo chauvinismo e técnica cultural, não durou. Foi cancelada pelo imperador sucessor e, mais tarde, até mesmo a construção de navios e viagens além das águas chinesas foram declarados crimes de pena capital. Mas, no curto período de sua vida, o Estado Chinês enviou mensagens, presentes e emissários para os cantos mais distantes ao sul do globo e obteve, em constante retorno, o reconhecimento de que era, por definição, o único estado verdadeiramente civilizado. ${ }^{25}$

No contexto atual, estou sugerindo que somente o que poderia ser chamado de culturas equivalentes com respeito ao poder, à complexidade e ao mencionado senso de autocerteza, provavelmente serão capazes de rejeitar ou adotar com alacridade o que é encontrado dentro de um intercâmbio transcultural do 
tipo que ocorreu durante as viagens de descoberta, tanto de leste a oeste quanto do oeste a leste. Embora ainda ignoremos a história asiática, é, pelo menos, evidente que as culturas milenaristas da Ásia tiveram uma viabilidade diferente daquelas da primeira categoria de culturas, as que eu denomino de monoculturas.

Exemplos de monoculturas que citei até agora incluem os aborígenes do interior da Austrália, os inuítes e os tasaday, aos quais podemos acrescentar qualquer número de grupos desaparecidos de tribos sul-americanas no Brasil ou no Peru. Algumas características semelhantes ou genéricas marcam a situação de uma monocultura. Em primeiro lugar, é marcada por algum grau relativamente elevado de isolamento cultural ou isolamento que protege sua integridade cultural. $\mathrm{O}$ caso mais extremo citado foi o aborígene, com dezenas de milhares de anos de isolamento.

O isolamento relativo do inuíte do Ártico foi semelhante; e em contextos tropicais, o isolamento pesado da selva é outra forma desta separação necessária de muitos e repetidos contatos interculturais. Tal isolamento fornece uma espécie de barreira natural que cria um habitat ou ambiente regional dentro do qual a monocultura pode elaborar sua fórmula de sobrevivência e equilíbrio. O modo como essas culturas conseguiram entrar em harmonia com seus ambientes, muitas vezes duros ou áridos, é o que atinge o admirador preocupado do final do século XX.

Naturalmente, aqueles que alcançam esse delicado equilíbrio são mais conhecidos do que aqueles que fracassaram. Para obter uma imagem mais clara, no entanto, as falhas ou falhas próximas também devem ser observadas. Seus ossos, incluindo o neandertal, e artefatos são o material de nossas paleontologias e arqueologias e são os predecessores da atual safra de extinções culturais, que, é certo, estão mais intimamente ligados às forças sociais do que naturais.

Contudo, as monoculturas são pequenas, estritamente controladas pela população por alguma combinação de controles culturais e naturais, e são, em certo sentido, raridades na história. Nem todos tiveram tais histórias ou mantiveram-se em condições escassas. Mais comuns são os movimentos expansionistas ou, muitas vezes, autodestrutivos, resultando em catástrofe. A queimada na agricultura é destrutiva e pode esgotar um ambiente rapidamente, a menos que a população se mantenha muito pequena. A desertificação, uma tendência previamente observada na Bacia do Mediterrâneo e hoje desenfreada na África Central, também é ambientalmente destrutiva. Em nenhum desses casos a alta tecnologia é a variável que causa o problema (com a notável exceção da tecnologia 
médica, que promove menores taxas de natalidade e morte e o prolongamento de mais pessoas idosas em uma população, circuitando assim a dura intrusão do ambiente natural a uma população humana).

Indiretamente, é claro, pode-se argumentar com mais força sobre os efeitos negativos da cultura de alta tecnologia nas culturas moribundas ou sob stress do Terceiro Mundo ou subculturas dentro dos interstícios da cultura industrial. A eliminação de terras anteriormente cultiváveis, a destruição dos habitats selvagens, a exploração de países pobres para tudo, desde o despejo de resíduos até a utilização do trabalho, são males que poderiam ser citados como pelo menos associados à infraestrutura econômica da cultura tecnologizada; mas aqui também estes não são fenômenos novos e nem pertencem unicamente às culturas do Hemisfério Norte.

O que torna a situação mais terrível e difundida é a maior ampliação de poder e maior impacto das tecnologias de hoje em comparação com as do passado. A introdução do arpão explosivo em navios modernos movidos a vapor proporcionou à pesca de baleia uma amplitude ainda maior em contraste com a indústria americana do século XIX e levou quase à extinção um dos maiores mamíferos do mundo.

Cada um destes fatores, no entanto, é indireto em comparação com o efeito ácido da cultura de alta tecnologia em habitats humanos tradicionalmente isolados ou desconhecidos que foram violados. O "outro" apareceu e nenhuma cultura pode ser uma monocultura no sentido de que elas podem ser o único "povo". Neste sentido, a tecnologia permitiu que os seres humanos contemporâneos "herdassem" toda a terra. Não no sentido meramente físico, mas cultural e é incorporado através dos vários artefatos, particularmente os da comunicação, que ligam toda a terra em uma rede. As próprias condições da existência monocultural foram violadas. Nem mesmo algumas tentativas atuais de criar o que equivale a "museus de cultura" funcionarão no sentido de salvar estas monoculturas. A condição para a estabilidade de uma monocultura é análoga à de um habitat para uma espécie especializada. Se este habitat é destruído, seja geográfica ou culturalmente, a condição para a monocultura é removida e ela ou morre ou adapta-se. Isto é apreciado e compreendido pelo o que eu chamo de "museu de cultura", ou seja, o movimento entre alguns antropólogos que gostariam de preservar tais habitats, por mais irreal que isso possa ser na situação atual. (O irrealismo relaciona-se mais com a falta de um impulso ambiental concentrado e poderoso dirigido às variedades de conservação do que a uma 
avaliação negativa, que precisaria de uma profunda conversão cultural para se tornar efetiva).

Por mais plausível que este esquema de quatro categorias seja para a classificação de agrupamentos de tecnologia cultural, falta-lhe a concretude tanto para tornar persuasivo um modelo multiestável como para reformular as questões que tenho criticado em relação ao controle da tecnologia. Voltarei, portanto, a um conjunto de exemplos da história recente para sugerir outra linha de argumentação.

Tenho insinuado que as tecnologias de comunicação contemporâneas são tão poderosas como o são por causa do múltiplo conjunto de dimensões que elas incarnam. Elas podem ser tecnologicamente complexas, podem ou não podem ser estreitamente ligadas a um conjunto igualmente complexo de envolvimentos instrumentais, e ainda assim permanecerem hermeneuticamente simples e virtualmente interculturalmente disponíveis com breves processos de aprendizagem hermenêutica implicados.

Os exemplos que citarei têm a vantagem também de mostrar alguns dos problemas com o "controle" de formas de incorporação da cultura-tecnologia. A ditadura é a forma de governo que mais fortemente tenta controlar as culturas e, inevitavelmente, procura controlar os meios de comunicação. Isto é mais facilmente alcançado em casos de tecnologias complexas, centralizadas ou de malha estreita. Os jornais de grande produção ou de televisão (até os dias do satélite) são os mais suscetíveis ao controle do governo, mas nenhum governo é totalmente bem-sucedido. Este também é um exemplo do fracasso da totalização. Um dos meios da derrota do controle total ocorre através do que hoje são os meios de comunicação de alta tecnologia, mas descentralizados, que podem comunicar-se pelo subterrâneo a uma população dissidente. Um exemplo notável desses meios foi o uso do minicassete durante a Revolução Iraniana. Embora o governo do Xá tenha sido relativamente bem-sucedido no controle da grande mídia, a propaganda e a comunicação de discursos revolucionários aconteceram, no entanto, através da distribuição das fitas pequenas e facilmente ocultas para tocadores de cassetes. Esta mesma indefensabilidade de um grande complexo de comunicações foi historicamente precedida por outro exemplo semelhante na indústria da música.

Durante décadas, a música popular foi controlada por um pequeno número de grandes gravadoras ligadas, por sua vez, a uma cadeia de estações de rádio. A música pop foi escrita virtualmente por fórmulas e divulgada através 
de jockeys de disco nas cadeias cativas. Quando pequenos gravadores de fita portáteis se tornaram disponíveis, no entanto, gravações amadoras de música folclórica, pequenos grupos e outras músicas anteriormente não convencionais começaram a circular. Isso foi bem-sucedido o suficiente para transformar toda a situação econômica dos "majores", tanto que as novas empresas formadas e os estilos de música preferidos se tornaram muito mais diversificados ao que havia sido através do sistema anterior. E embora um novo conjunto de "majores" agora tem re-dominado o campo, o resultado claramente é que uma variedade maior de estilos de música popular ainda sobrevive ("country western", "swing", muitas variedades de "rock", um dos estilos proliferados da revolução "clássica”, etc.).

Embora exista uma analogia na distribuição entre o exemplo iraniano e as revoluções da música, há também uma desanalogia. O novo regime fundamentalista que finalmente conseguiu derrubar o Xá, por sua vez, procurou controlar a mídia, agora com sua nova mensagem. Embora exista uma analogia na distribuição entre o exemplo iraniano e as Revoluções da Música, há também uma desanalogia. O novo regime fundamentalista que finalmente conseguiu derrubar o Xá, por sua vez, procurou controlar a mídia, agora com sua nova mensagem. Embora a tentativa de controle deste novo regime permaneça paralela com a recaptura do complexo de distribuição de música pelos militares, é diferente no que diz respeito ao aspecto de que qualquer expansão resultante da variedade não é aparente. Aqui, ao menos em princípio, outra pista sugerida a respeito da emergente não neutralidade cultural da tecnologia contemporânea pode começar a ser avistada.

Essa pista, sustento, está no padrão pluricultural essencial que a tecnologia contemporânea torna possível. É, no entanto, uma inclinação, não uma determinação de tecnologia, como os graus de restrição contra um resultado pluricultural continua a ilustrar. Mas um padrão pluricultural também é não neutro.

O que os sistemas totalitários mostram é que governos fortes e controlados centralmente podem ser bem-sucedidos na manutenção de um sistema dominante/recessivo de comunicações. Na medida em que as visões recessivas não podem ser totalmente suprimidas, elas podem e existirão como mediadas pelas minitecnologias variáveis que permitem a distribuição ao lado de muitas das maxitecnologias que permanecem controladas. $\mathrm{O}$ conjunto atual de tecnologias de publicação eletrônica, gravadores de cassetes e câmeras de vídeo está proporcionando oportunidades para a expressão de minorias descentralizadas. Recentemente, por exemplo, à alegação frequentemente repetida de que há brutalidade 
policial, uma reivindicação quase sempre difícil de provar e geralmente descartada por conselhos de revisão, foi dada uma nova versão através do uso de uma câmera de vídeo durante uma disputa sobre um toque de recolher na cidade de Nova Iorque. Os resultados foram tão dramáticos que o comissário da polícia agiu prontamente para demitir e reorganizar pessoas de alto escalão na cadeia de comando. Da mesma forma, os potenciais da televisão para as decisões apertadas em eventos esportivos estão mudando o papel e a posição dos árbitros.

O que os sistemas não totalitários mostram ainda mais claramente é a possibilidade positiva de resultados pluriculturais. A televisão, agora com capacidade multicanal, permitiu que o espanhol - o que por muito tempo tem sido uma segunda língua "não oficial" nos Estados Unidos - se tornasse um importante meio de expressão através de vários canais em espanhol. Há canais menos difundidos em coreano, japonês e outras línguas que não pertencem ao mainstream indo-europeu.

Se, contudo, um resultado pluricultural tem sua própria forma, sua própria característica de não neutralidade, é importante mostrar o que esta trajetória inclinada apresenta. Por essa razão, voltarei mais uma vez a um conto imaginativo.

\section{F. A revolução culinária de Adão e Eva}

Retornemos pela terceira vez ao jardim imaginário não tecnológico de nosso par primordial imaginado. Neste cenário não tecnológico, a cena culinária necessariamente teria que ser um pouco como o que segue: em primeiro lugar, não pode haver nenhuma transformação tecnológica de alimentos. Assim, ao modo de Levi Strauss, o "cru" será a única possibilidade cultural; o "cozido", uma vez que envolve fogo, ferramentas e, pelo menos, um conjunto mínimo de tecnologias, é deixado de lado.

Isso nos deixa com o que pode ser chamado de "Núcleo da Cozinha do Jardim." Tal núcleo incluirá, pelo menos, frutas e vegetais crus, aqueles que podem ser digeridos e utilizados sem transformação. Será assim consideravelmente mais restrito do que a dieta aborígene, que incluiu alimentos tóxicos transformados. Poderia conter preparações do tipo do sushi de peixe cru e carne. Haveria nozes e coisas do gênero. Tal dieta, embora provavelmente saudável, seria, para o paladar moderno (exceto para o fundamentalista do "alimento natural"), chata.

Para que o exemplo não seja considerado demasiado frívolo, note que as cozinhas estão completamente tecnologicamente preparadas e culturalmente 
embutidas em práticas que contam com longas histórias de tradição. As revoluções anteriores incluíram primeiramente o uso do fogo, o protótipo do nosso próprio churrasco; mais tarde, com panelas, as fervuras; e ainda mais tarde, com fornos, os assados. O falecido James Feebleman certa vez apontou que fornos e fogões são "estômagos" tecnologicamente externalizados, uma observação em consonância com a "incorporação."

Além disso, como observado anteriormente, desenvolveram-se tradições distintas de ambas as cozinhas e as tecnologias através das quais essas cozinhas foram preparadas. À medida que a arte culinária se tornou mais civilizada, surgiram indústrias inteiras relacionadas à porcelana, aos utensílios de cozinha, etc., que envolviam redes complexas de processos metalúrgicos, fornos e sistemas de distribuição (a arqueologia mediterrânea é repleta de urnas de óleo e vinho da região). A cozinha é, de fato, um excelente exemplo de distribuição e evolução tecnológica de uma forma multidimensional.

Vamos, no entanto, trazer o conto até o presente novamente. Suponha que nós trazemos a nosso par algumas das variedades multiculturais da culinária que foram introduzidas em nossas próprias terras somente nas últimas décadas. Em primeiro lugar, o que já foi "O Dia do Príncipe Espaguete” proliferou em cozinhas regionais italianas. (Como eu escrevo isso de uma Canônica nas colinas sobre Florença, posso verificar a solidez desta proliferação. Alimentos italianos do Norte são diferenciados dos alimentos do Sul da Itália; Toscana, da Sicília.) Na comida chinesa, uma vez que apenas o "chop suey" era o mais importante dos alimentos não ocidentais para os americanos, a escolha agora deve ser feita entre Hunan, Sichuan, Mandarim, etc. A estas diferenciações mais finas deve ser adicionado todo o espectro de tradições culinárias mais recentes e menores, como vietnamita, tailandês, afegão, indiano em todas as suas variedades, etc. Há mesmo uma curiosa virada contracultural ou contracontrole na recente história culinária. Praticamente toda nova conquista neocolonial ou movimento opressivo traz em seu rastro uma forma de "vingança cultural" culinária. Desde os dias do movimento dos direitos civis, com a popularidade do "alimento da alma”, para o surgimento hoje do alimento etíope, cada interesse de um grupo de objetos ou de pessoas testemunha uma cozinha vir à tona.

Há inovação que brota do desenvolvimento pluriculinário. A nouvelle cuisine mistura elementos da cozinha francesa e oriental, a comida do Oriente Médio adota hoje técnicas da cozinha light, etc. Uma vez que o nosso casal primal prove e torne-se aculturado para esta variedade de cozinhas, eu apostaria que 
o retorno ao Jardim se tornaria indesejável e provavelmente irreversível. Mas a pluricultura culinária é um efeito do pós-Jardim, tecnologicamente herdado do mundo.

Este conto de não neutralidade culinária é um análogo do que considero uma das principais trajetórias da cultura contemporânea, ligada ao mundo, de alta tecnologia. Esta pluriculturalidade é agora uma aquisição do mundo da vida contemporâneo e, como tal, é uma característica permanente desse mundo da vida. Não é neutro, no entanto, em vários aspectos. Primeiro, como uma aquisição, serve como um impedidor de retorno à monoculturalidade do Jardim. Toda pluriculturalidade é ácida para a monoculturalidade. Segundo, enquanto a pluriculturalidade permite a persistência de uma variedade de "culinárias" no exemplo, tradições culturais no sentido mais amplo implicam que nenhuma pode ser considerada simplesmente como "verdadeira", a única "pessoa real", etc. Pode ser uma escolha deliberada de, ou escolhendo deliberadamente a, cultivar um em vez de outro tal tipo de alimento, é agora uma escolha autoconsciente e, portanto, parcialmente arbitrária. E terceiro, esta escolha será submetida a testes e revisões constantes. Se o processador de texto tornar impossível a noção de um texto "final", a pluricultura torna obsoleta uma única tradição privilegiada.

A forma do mundo da vida contemporânea como pluricultural é também ácida aos "núcleos" modernos e pré-modernos, "fundações" ou outras integrações finais e absolutas ou mesmo unificadas. A pluricultura como uma forma tecnológica do mundo da vida é claramente pós-moderna num sentido limitado. (Eu usarei pós-moderno num sentido de alguma forma técnico não inteiramente relacionando-o com o seu uso presente. "Pós-modernismo" na filosofia seria pós-cartesiano, pós-kantiano, pós-fundacionalista. Na cultura tecnológica, poderia ser emergente pós-industrial.) E porque é assim, as nostalgias latentes dos profetas da distopia tecnológica são tanto certas quanto erradas em relação ao futuro da cultura tecnológica.

Se eu estou certo sobre esta forma de multiestabilidade, então as previsões de uniformidade analítica (Marcuse), da vitória da técnica (Ellul) e até mesmo do mundo puro do pensamento calculista (Heidegger) estão erradas. Haverá diversidade, mesmo mais diversidade, dentro do conjunto de tecnologias e suas múltiplas ambiguidades, num futuro próximo.

Contudo, a menos que se sinta erroneamente uma vertente utópica inconsistente, é bom sublinhar que toda a não neutralidade mantém a ambiguidade essencialmente nem positiva nem negativa. Se todas as tecnologias e agora, aqui, 
uma sugestão de um conjunto de tecnologias forem seletivamente transformativas, deve-se supor que ele se aplica ao único exemplo culinário parcialmente imaginativo.

Em sua narração talvez demasiado imaginativa, o conto negligencia outros aspectos das tendências culinárias contemporâneas. Poderia ser que essas múltiplas cozinhas todas preparadas com carinho por qualquer chef com longos estágios ou jovens empreendedores aspirantes permaneçam sob os sinais dos últimos estágios do artesão qualificado que foi arruinado pela desqualificação da Revolução Industrial? Esse processo também é claramente evidente. De cada grande e pequena cidade da cultura tecnológica mais maximalista (os Estados Unidos), os "arcos duplos" ${ }^{26}$ aparecem agora também a apenas um quarteirão da Escadaria da Praça da Espanha em Roma e, com as variedades relacionadas de fast-foods, em grande parte do mundo desenvolvido.

Tais cadeias de fast-food são o epítome dos processos agora computadorizados da linha de montagem pioneiros nos dias de Ford e de Taylor. Não há trabalhadores chefs qualificados, são todos desqualificados, e se pode aprender as etapas do processo de forma rápida e fácil. Os empregados são desde as pessoas que vivem nas periferias aos adolescentes e, mais recentemente, os idosos tornam-se as principais fontes de trabalho para as cadeias de fast-food. O mercado também é interessante na medida em que, na Europa em particular, a operação de fast-food tornou-se o "ponto de encontro" para a juventude na moda. Jeans, comida americana e rock-and-roll são os pontos de fascínio em um complexo que serve como um novo "machado de aço" ou "relógio de pulso" para a cultura juvenil como análogos aos exemplos anteriores. Em Bacheretto, a aldeia toscana a partir da qual este livro está sendo escrito, o pequeno bar da aldeia, para onde devo viajar todas as semanas para fazer a chamada de escritório necessária, está constantemente cheio de adolescentes sentados diante do canal "MTV", ouvindo canções como "French Kissin in the USA."

Admito que os distópicos mencionados poderiam tomar essas observações e, dado o que eu particularmente suspeito, seja um elitismo escondido combinado com a nostalgia de algum folclore do passado, tivessem um rampante com esta tendência. Não se pode negar que o fenômeno de uma cultura juvenil combinada com a cultura popular é um fato importante da civilização de alta tecnologia. Além disso, é interculturalmente internacional e reage imediatamente de Tóquio a Nova Iorque a Moscou. Voltarei a esta vertente do presente novamente. 
A cultura pop-jovem, no entanto, é apenas uma das pluriculturas que pode ser tomada no meio do espectro pós-moderno de outras tradições. Pode ser uma forma contemporânea única de cultura, mas não é exclusiva e, em alguns aspectos, é limitada precisamente por sua vinculação a uma faixa etária.

O exemplo culinário, tanto em suas formas imaginativas quanto empíricas, não se encaixa no modelo de multiestabilidade que esbocei. Cada variante culinária, como as variações perceptuais no cubo, tem sua aparência distintiva e, na medida em que é genuinamente distintivo, é exclusivo ou alternativo às outras variantes. Na medida em que as cozinhas são mais complicadas do que os perfis do exemplo visual, há possíveis misturas, inovações únicas e similares que podem ser desenvolvidas além dos limites do exemplo do cubo. Isso, entretanto, é um argumento para mais e não menos diversidade "culinária".

Sugeri também que o paladar pós-moderno está "ciente" desta multiestabilidade. Ele adquiriu uma multiplicidade de gostos precisamente como uma aquisição do mundo da vida, impedindo, assim, que o gosto seja reduzido a qualquer "núcleo", "fundacional" ou, na maioria dos casos, sofisticados, até mesmo uma estreita faixa de gostos preferidos. Distintivo sobre este paladar pós-moderno é a sua capacidade de mudança para apreciar a gama de perfis culinários.

Uma consequência desta ascensão no status pluripalatar é sua não neutralidade que será percebida por qualquer pessoa que ainda habita em uma posição fundacionalista ou que tenha perdido alguma sensação de raiz ou como diletante em gosto. Ao contrário, a pessoa que alcançou o pluripalato provavelmente considerará o detrator moderno como desesperadamente provinciano e nostálgico por um passado há muito substituído.

Este é o mesmo ganho e a mesma perda que cada saída do Jardim implica. É o preço de herdar a terra. O problema para o contemporâneo, no entanto, é que na presença de pluriculturalidade há tanto não neutralidade sobre esta presença e inevitabilidade em contextos maxitecnológicos. O conto culinário, no entanto, implica uma projeção mais séria. A multiculturalidade é uma verdadeira trajetória resultante da disseminação da tecnologia em todo o mundo. Acompanha o alcance e a extensão de toda a invasão tecnológica contemporânea no que foi tomado como dominação da tecnologia "ocidental". A multiculturalidade é um lado inferior desse aparente domínio de uma história associada à tecnologia euro-americana.

Ao final deste segundo programa parece, então, que uma forma diferente de determinação tecnológico-cultural reapareceu. Sua forma é distintamente 
diferente da proposta pelos antagonistas e defensores da maioria do futurismo tecnológico, mas sua presença é perplexa na medida em que constitui um quadro para a escolha contemporânea. Assim, um terceiro e último programa será inserido, um que se concentra nas curvaturas únicas do mundo da vida contemporâneo. 


\section{7 \\ Programa Três: Contornos do Mundo da VidA}

A tarefa deste terceiro programa concernindo tecnologia e o mundo da vida é distintamente contemporâneo. Seu objeto é uma topografia parcial das curvaturas do mundo da vida. Aqui eu tenho que optar por uma escolha limitante. Eu não devo ser tão ousado ou ir tão alto no sentido de propor uma topografia total, ainda que eu deseje, nesta análise, alcançar alguns dos tópicos importantes que vem surgindo com base nas tecnológicas contemporâneas. Eu optei por fazer uma topografia parcial que leia o mundo da vida primariamente nos termos de um importante e relativamente novo conjunto de tecnológicas, as quais eu chamarei tecnologias de imagem. Estes incluem não apenas a televisão difusa, cinema e fotografia, mas também computadores - igualmente em termos de capacidade com palavra e número e computação gráfica, etc.

Esta é uma escolha de nível médio para a topografia, simultânea e suficientemente concreta para permanecer intuitivamente ligada às tecnologias incorporadas e também especulativa e ampla o suficiente para capturar o que eu acredito ser único ou distintivo para a era pós-moderna. Quais são as formas para a não neutralidade tecnológica neste mundo da vida pós-moderno?

Eu chamei a situação atual de "pós-moderna", não apenas por estar na moda, mas porque, em seu uso generalizado, é um termo que anuncia uma consciência de que estamos numa transição da aura do moderno para o que ainda não é facilmente nomeável. Se isto é assim, é igualmente difícil ter certeza sobre o 
estado atual das coisas ou fazer uma afirmação segura sobre possíveis, e muito menos prováveis, trajetórias. No entanto, há vetores discerníveis que aparecem; e aqueles, por mais vagamente associados com as tecnologias de imagem que possam ser, são de particular interesse. Eles também têm a vantagem de manter a investigação focada na práxis e percepção, igualmente micro e macro, do mundo da vida.

A postura que eu adotei ao longo das tentativas foi para evitar tanto as tentações utópicas e distópicas que facilmente se tornam os pecados de muitos intérpretes da tecnologia. No entanto, ao esboçar agora um conjunto sugestivo de curvas da cultura de alta tecnologia, devo reconhecer que a restrição da mera descrição será superada. Ambas as esperanças e os medos que alguém possa ter devem mostrar-se. Reconheço que sou um cidadão do próprio mundo da vida sendo atraído e, como tal, experimento os amores e os ódios que sempre se tem pelo próprio país.

Aqui, também, devo confessar a relação amor/ódio semelhante que tenho para com as tecnologias. Compartilho com muitos dos críticos da civilização tecnológica os seus maiores receios de que, desprovidos da necessária ética e lei de conservação que precisamos, talvez já estivéssemos perto de ter irremediavelmente contaminado nossa própria terra no momento em que a herdamos completamente. Essa possibilidade sombria, embora não inevitável, é o suficiente para sinalizar a morte com um gemido pelas vidas humanas no planeta. Eu temo essa possibilidade mais do que a outra morte por meio da possibilidade do holocausto nuclear global, que também é possível, embora não inevitável.

Rejeito a noção popularizada por Heidegger de que "somente um deus pode nos salvar". Nem eu tenho qualquer fé de que isso poderia ou aconteceria. Naquilo que afirmo ser mais um senso de contingência, devemos mais do que nunca ficar atentos ao nosso próprio destino, por meio da profunda e ainda mais cuidadosa atenção ao nosso mundo tecnologicamente texturizado. Embora não possamos simplesmente "controlá-lo", uma vez que a questão é erroneamente enquadrada, há direções que podem ser tomadas em meio a interstícios cruciais que poderiam produzir alguns cutucões significativos.

Muitos destes também pertencem à gama de tecnologias de imagem. Mas se eu estou evitando o utopismo, tampouco desejo ser distópico. O mundo tecnológico contemporâneo mostra vantagens distintas, vantagens estas que se tornaram tão completamente tidas como certas que é fácil ignorar tais mudanças 
em relação a todos os "mundos" anteriores. Nem sequer experimentamos o sentido existencial do que essas mudanças têm sido.

A mudança mais positiva e dramática que afeta a vida diária vem ocorrendo na área dos avanços médicos e tratamento à saúde. Passaram-se muitas doenças: poliomielite, varíola, e tudo menos vestigial, cólera e difteria, doenças da infância muitas vezes fatais e outras tão numerosas que a lista encheria a página. Poder-se-ia dizer que essa mudança também é ambígua em algumas áreas cruciais do planeta e que teve como efeito colateral o efeito deletério de aumentos populacionais que complicam a questão da pobreza. Mas nos países desenvolvidos, novamente através da adaptação das tecnologias de controle da natalidade, esse problema também desapareceu. Poder-se-ia também dizer que o sentido religioso da contingência da morte, um fenômeno diariamente presente no mundo europeu do século XIV, quando a praga exterminou um terço ou mais da população, foi perdido enquanto um significado religioso. Mas eu, por exemplo, não lamento essa perda; e embora eu pense que nossas atitudes atuais em relação à morte e as formas institucionais com que lidamos com ela claramente precisam de melhorias, não gostaria de trocar a nossa postura pelo sentido passado de morte iminente. Nesta e em muitas outras formas, admito alegrar-me com a modernidade.

Os exemplos de navegação que usei ao longo deste livro também se relacionam com minha própria experiência positiva com a tecnologia. Eu sou um marinheiro "religioso" naquilo que não está muito longe da verdade em afirmar que a vela é o meu substituto secular para a religião em seu ritual de celebração e em outras funções de elevação redentora. Aqui eu sou des-romanticamente, completamente moderno no gosto. Estou disposto a argumentar que o veleiro de alta tecnologia contemporânea é muito superior e ainda mais em contato com os elementos naturais do que qualquer embarcação tradicional. Eu posso apreciar particularmente os cheiros de alcatrão e molho de cânhamo associado aos barcos de madeira velha, e eu gosto dos sons de seus trabalhos de rangido. Mas, tendo navegado em muitos deles, eu sei muito bem que o desempenho no meu próprio modelo moderno da série de fibra de vidro é tal que, seja em condições extremas, em que a habilidade de navegar sozinha significa mais para a segurança do que o barco, ou em condições normais em que a maior facilidade de manuseio e manutenção proporciona um desfrute maior e, ainda, com uma proporção de vela muito menor para reparar são aspectos mais do 
que suficientes para compensar qualquer nostalgia que possa haver em relação à ancestralidade de madeira.

Além disso, o moderno barco de alta tecnologia, precisamente na sua capacidade de permitir-se ser incorporado através dele, aproxima e coloca a pessoa muito mais em sintonia com o vento e a água do que era possível de ser alcançado por meio de uma embarcação de madeira mais velha e de difícil condução. Para um leigo nas questões da navegação, uma analogia possível entre os barcos antigos de madeira e os modernos de fibra de vidro seria algo como a experiência de estrada que alguém tem com um carro esportivo moderno em comparação com os velhos modelos de carros grandes americanos no que diz respeito ao conforto e "visando" desfrutar a paisagem nas estradas tortuosas na altitude da montanha aqui na Toscana.

Inevitavelmente, eu revelei que também posso elogiar a tecnologia de uma forma próxima à não crítica, uma ode não característica da restrição anterior. Isso não diminuirá o sentimento mais profundo de ambiguidade que deve ser mantido se a crítica for permanecer genuína. Com isso, volto-me para a difícil e um pouco especulativa tarefa de delinear as curvaturas do mundo tecnológico contemporâneo, como visto especificamente através dos papéis das tecnologias de imagem.

\section{A. Pluriculturalidade}

A primeira curvatura do mundo da vida contemporâneo é alcançada agora no que eu chamo de pluriculturalidade. Trata-se de uma forma de vida que surge do uso de tecnologias de imagem que alcançam as culturas. Vou usar esse neologismo para contrastar com o transcultural e o multicultural, que são fenômenos relacionados e não necessariamente formados por mediações tecnológicas.

Existe uma ilusão persistente de neutralidade que se associa a todas as tecnologias. Sua forma mais simplista, a neutralidade de meros objetos em contraste com usos motivados por sujeitos, tem sido evitada aqui pelo uso do modelo relativista que se nega a dissociação entre o sujeito e o objeto nos usos da tecnologia. Mas a ilusão pode persistir precisamente por causa da multiestabilidade que observamos anteriormente, em que uma multiplicidade de usuários pode se apropriar e usar tecnologias de maneiras tão diferentes. Isso ocorre também no nível de uma hermenêutica cultural, na qual as tecnologias são incorporadas de forma diferente. O surgimento da pluriculturalidade será visto como a chave 
para uma não neutralidade essencial e servirá como uma forma de desconstruir essa ilusão no nível cultural.

Pluriculturalidade é a forma distintamente pós-moderna do multicultural. Ela surge em e através de tecnologias de imagem e é levada para as aquisições do mundo da vida. Sua própria aparência imita aspectos do multiestável. As tecnologias de imagem são exemplificadas por uma série de tecnologias, incluindo televisão, cinema e também displays de computador com processamento de palavras e números, bem como gráficos, fotografia em todas as suas formas, etc. Cada uma dessas tecnologias de imagem tem a capacidade de 'reproduzir' ou 'produzir' "imagens". (Fenomenologicamente, estou muito desconfortável com esta linguagem sobre a imagem, porque esta utilização é amplamente usada agora para simplesmente descartar, com base na teoria plantonista da cópia e representacionismo, o que a fenomenologia tem superado. Fenomenologicamente, uma 'imagem' é em si uma "coisa em si", isto é, um fenômeno distinto. É positivo, com sua aparência própria, e que não pertence necessariamente à "representação", mas sim a uma apresentação distinta. Utilizo a linguagem da imagem, colocando-a entre aspas simples para indicar a rejeição de sua epistemologia associada.)

Muitas vezes tomamos essas tecnologias como sendo simplesmente "reprodutores" neutros de alguma coisa real em uma "imagem" isomorficamente produzida. Mas nenhum usuário crítico ou especialista em mídia acredita mais nisso. Na verdade, a câmera é um excelente exemplo de não neutralidade tecnológica, precisamente no sentido de que qualquer foto transfigura o objeto que é "retratado". Quanto mais sutil a transfiguração, maior a ilusão de neutralidade; mas para os olhos mais agudos do final do século XX, pelo menos, em comparação com os primeiros espectadores ainda não educados para transfigurações, essa ilusão é agora vista mais como uma ilusão de representação.

O espectador ingênuo não perde a importância de ser "retratado" e transformado pela câmera. Em meados dos anos 1950, fiz uma viagem de estudo em culturas nativo-americanas do Sudoeste, que incluiu visitas aos assentamentos navajos, hopi e taos. Cada grupo reagiu de forma diferente à câmera. Os navajos estavam relutantes ou se recusavam a tirar suas fotos. A explicação dada era que a 'imagem' realmente estava tirando algo da pessoa cuja foto estava sendo tirada. Isso tinha um sentido quase "material", embora fosse num sentido material "espiritual". Os hopi, também relutantes, às vezes deram como razão para não serem fotografados a crença de que tais fotos seriam colocadas em um uso 
que de algum modo iria explorá-los, talvez fossem utilizadas com o propósito de obter lucro por alguma revista, de modo que a pessoa sendo retratada não se beneficiaria. O grupo de taos não se importou que suas fotos fossem tiradas, desde que fossem pagos pela operação. Em cada caso, havia uma percepção da não neutralidade da tomada de imagens, embora não fosse elogiada ou contextualizada de uma forma que pudéssemos colocar desta forma.

Embora uma fenomenologia rigorosa da transfiguração fosse apropriada, ela se encaixaria melhor nas transformações anteriores de visão já observadas. O que eu tenho em mente aqui é mais que a ilusão de neutralidade decorrente da capacidade das tecnologias de imagem em transmitir, em retratar qualquer assunto visualizável em, neste caso especial, a capacidade não apenas de transmitir, mas transfigurar o assunto cultural.

Transmitir 'imagens' culturais foi um dos primeiros usos da fotografia na agora centenária revista National Geographic. Ela revolucionou a atmosfera das salas de estar de muitas famílias, trazendo pictoricamente para muitos povos provinciais a variedade de culturas do mundo não conhecida anteriormente. Ela revolucionou o que era aceitável em sua própria tradição, começando em 1896, por exemplo, representando mulheres de peito nu. Colocado no contexto mais objetivo de fotos autênticas de povos autênticos, o assunto anteriormente proibido para crianças, pelo menos se tornou aceitável. A primeira educação visual sobre a anatomia feminina para muitos rapazes na virada do século pertencia precisamente a essa convenção da Geographic.

O que está mais na profundeza do que o mero fascínio do espectador na agora nitidamente inocente datação desta prática, no entanto, é a abertura à pluriculturalidade que também começa a se mostrar através deste uso da tecnologia. Trazer uma cultura diante da outra não é uma relação unidirecional. É uma inter-relação, mesmo em nível aparentemente trivial da fotografia de revista. O análogo à vingança culinária do conto é a 'imagem', que começa a transformar o lar previamente isolado ou insulado.

Mais uma vez há uma relação entre o crescimento da tecnologia da imagem em uma base quantitativa para o salto qualitativo que ocorre junto à proliferação. A exibição multicultural da Geographic foi apenas uma abertura precoce para a virtualmente constante interculturalidade, hoje vista diariamente nos noticiários noturnos da televisão. Nenhum moderno informado pode não estar consciente da distinção cultural. 
A criança informada de hoje, através de documentários televisivos sobre antropologia, conhecerá algo sobre fenômenos como potlatches, respeito aos antepassados, rituais de iniciação à puberdade e toda uma gama de fenômenos culturais paralelos aos conhecimentos semelhantemente documentais sobre buracos negros e o desvio para o vermelho na astronomia. Essa criança contemporânea é uma criança melhor informada do que aquela que viveu no tempo em que a National Geographic nasceu. Ao lado do esoterismo dos documentários sobre antropologia encontra-se a imagem muitas vezes mais atraente do canal MTV, que quase sempre encontramos ainda sintonizados quando nossas baby-sitters partem. Além de "reproduzir" imagens, a televisão contemporânea produz imagens de seu próprio tipo. Ela cria algo de sua própria subcultura. As 'imagens' produzidas, refratadas e fragmentadas da TV pop são os remanescentes de bricolagem da fotografia posta em movimento, mas que produzem suas próprias variantes.

Esse conhecimento por meio de 'imagens' também não é neutro. Está tão distante do Jardim quanto todas as outras formas de conhecimento tecnologicamente mediado que observamos. O clamor contemporâneo contra o relativismo é mais uma forma de protesto nostálgico. Os manifestantes experimentam a diminuição da estatura que nossa própria história tem em resposta à submersão e na multiplicidade de outras culturas. Mas, ao mesmo tempo, a aparência de uma cultura popular produzida, "saturada de imagens", cheia de fragmentos multiculturais, também é percebida como ameaçadora. O relativismo cultural, no entanto, é apenas uma forma trivializada e muitas vezes degradada de pluriculturalidade. É também o sinal da penetração do pluricultural.

Uma das razões pelas quais a excelente imagem inicial da Geographic pode parecer tão inocente para nós hoje é porque ocorreu no final das explorações mundiais, quando ainda era possível sentir tanto o zelo missionário quanto o simples chauvinismo ocidental. Cada cultura exótica 'imaginada' pode ser fascinante, mas também entendida como "primitiva" ou "selvagem" e pensada para ser trazida para a "nossa" era moderna.

Depois que o nosso mundo incidiu sobre o deles, há agora uma contranostalgia dirigida ao fato de se ter perdido o "primitivo" e o "selvagem". Só existem ecos ou restos culturais. E estes são às vezes emprestados ao modo da bricolagem para as canções ou para as roupas e modas da cultura popular.

Se, por um momento, essa aparência de pluriculturalidade é lida como a última variante de uma série de revoluções do conhecimento científico, surge 
um interessante conjunto de paralelos. A ortodoxia de livros de texto em relação às explosões de conhecimento de ciências geralmente segue um mito quase ritual: uma nova ciência aparece em uma teoria que, por sua vez, muda uma grande crença anterior, que deve ser abandonada/descentrada e uma nova era de conhecimento informado emerge.

A revolução copernicana presumivelmente descentrou o universo geocêntrico, deslocando a terra e o humano para a órbita do sol, eventualmente para o status de um planeta menor dentro da Via Láctea. A Revolução Darwiniana, ao relacionar os seres humanos com os primatas, presumivelmente descentrou o antropocentrismo. Se a explosão do cultural é própria explosão mais recente do conhecimento do século XX, isso significa que o descentramento do eurocentrismo está prestes a ocorrer? Estamos à beira de um descentramento do universo cultural ocidental? Isso é claramente o medo sentido e que agora vem sendo debatido no ensino superior.

Sem endossar necessariamente os pontos de vista ortodoxos das explosões de conhecimento, há um interessante paralelismo instrumental ao que se seguiu a cada uma das referidas revoluções. Em cada uma, foram inventados novos instrumentos; estes, por sua vez, trouxeram à luz da percepção o que antes era invisível. Seguiu-se a transformação de micro e macropercepções, o que levou a mudanças de sensibilidade. A variedade atual de tecnologias que tornam o presente pluricultural é o espectro de tecnologias de imagem que acompanham essa familiarização que é basicamente apenas centenária. Acelerada pela instantaneidade das comunicações mundiais, a atual revolução está sendo rapidamente disseminada.

A história intercultural é, obviamente, muito mais antiga do que a sua história mediada pela tecnologia da imagem. Uma leitura profunda de nossa história mostra que os intercâmbios interculturais existem em cada momento crucial dessa história. Mas com a aceleração do intercultural durante as viagens de descoberta, particularmente para o Novo Mundo, depois para o Pacífico, até as partes anteriormente desconhecidas do Oriente, o fascínio também acelerou. As mudanças macroperceptivas que surgem a partir de uma revolução, no entanto, não foram facilmente acomodadas ou absorvidas. Aquelas levaram mais tempo; uma história perceptual revela algo da dificuldade que nossos ancestrais tiveram ao perceber o "outro".

Colombo manteve-se convicto até a sua morte de que os aruaques e caraíbas que ele descobriu eram apenas tribos do Leste Indiano em algum lugar 
fora da costa do continente. A lentidão de uma revolução cultural e perceptual também é evidenciada nas representações dos povos do Novo Mundo por colonos e missionários.

As primeiras representações coloniais dos povos indígenas do Novo Mundo parecem estranhamente europeias e ancoradas no estilo renascentista clássico, exceto pelos adornos de penas e na representação das roupas (ou na falta delas). $\mathrm{Na}$ América do Norte, não foi até chegar-se próximo à destruição dos ambientes originais dos nativos americanos, que através das obras de Catlin, Remington e da fotografia primitiva que começou a aparecer semelhanças representacionais realistas. Nem é preciso escolher apenas exemplos ocidentais para ilustrar o mesmo ponto. As primeiras representações japonesas da frota de Perry têm a mesma aparência cultural central nesse caso, a japonesa. Em ambos os casos, o contato cultural inicial ainda não é o pluricultural.

A pluriculturalidade precedente, em mais um paralelo com as explosões do conhecimento passado, foi o desenvolvimento de uma nova ciência: a antropologia. A antropologia seguiu as viagens de descoberta por vários séculos. A exploração, com a abertura para o Ocidente dos povos do Novo Mundo e do Pacífico, serviu como uma mudança no mundo da vida equivalente ao da tecnologia medieval para o nascimento da ciência. Esta experiência multicultural já estabelecida conduziria apenas mais tarde ao exame reflexivo e científico das culturas; mas, uma vez adentradas, as fronteiras da história cultural não seriam modificadas de uma maneira menos revolucionária do que qualquer um dos descentramentos anteriores.

Não importa quão lenta a gestalt fosse aparecer, uma vez que a trajetória explosiva é lançada, começa uma expansão cumulativa e quantitativa, agora multiplicada na forma da amplidão típica por nossas tecnologias de imagem. $\mathrm{O}$ primeiro resultado quantitativo em um cânone "explodido". O cânone anterior pode permanecer o que é apenas enquanto ele é pequeno e seletivo o suficiente para permanecer sedimentado. Com explosões lineares a princípio, depois horizontais e verticais, o cânone central deve enfraquecer. Isso já aconteceu e está acontecendo com nosso próprio sentido do humano, que se tornou histórica e culturalmente multifacetado:

(a) Começando apenas um pouco mais de um século atrás, o início da história humana foi primeiro empurrado linearmente para trás. No início, mesmo o "pré-diluviano" era difícil de perceber ou aceitar, mas hoje é um lugar-comum. Vindo primeiro com a Revolução Darwiniana, o alongamento do tempo humano 
para trás é agora mais de dois milhões de anos. Na verdade, a mais recente teoria sobre o Homo Sapiens moderno, conseguida através de uma retroprojeção de material genético, aponta para uma origem na África Central \pm 100.000 anos atrás. O Homo Erectus, claramente humanoide, tem uma história estabelecida de mais de um milhão e meio de anos, mais velhos do que os limites mais velhos concebidos para o tempo da terra apenas alguns séculos atrás.

Tais descobertas, que denotam uma aparência científica, geralmente são retratadas na mitologia padrão como a revolução intelectual que finalmente desafiou e desmistificou nossas noções religiosas ocidentais mais antigas e mais provinciais. Mas não devemos esquecer que culturas diferentes da nossa, sobretudo a dos antigos chineses e indianos, mantinham por milênios crenças sobre a era da terra e dos seres humanos, embora com pouca aparência científica, que se estendem em ciclos de centenas de milhares de anos.

O descentramento de nossa história anterior, curta e linear, também é parte de uma reação contemporânea. O relatório de William Bennett ${ }^{1}$, To Reclaim a Legacy (NEH, 1984), lançou um debate sobre "retornar" a um currículo restrito e virtualmente totalmente ocidental. Tal reação, entretanto, não pode eliminar a consciência que agora existe sobre este passado canonicamente explodido. Preston Adams, um biólogo, fez um bom apontamento em resposta à reação na Chronicle of Higher Education (23 de janeiro de 1985):

Mas, e quanto à alfabetização de espécies? Não deveriam nossos graduados também ter alguma compreensão das raízes da cultura humana, as raízes que se estendem para trás no passado mais de três milhões de anos?

Somente nos últimos anos os arqueólogos e paleoantropólogos começaram a entender o mundo dos seres humanos pré-históricos de uma maneira sistemática. Essas disciplinas têm, nas últimas duas décadas, produzido uma inundação cada vez maior de novos conhecimentos sobre os seres humanos que:

(a) desenvolveu um precursor da escrita em símbolos de argila que funcionou bem por cerca de 5.000 anos antes de sua rápida transformação na primeira escrita cerca de 3.000 a.C.;

1 NT: William John Bennett (1943- ), é um político conservador dos Estados Unidos, foi Secretário de Educação do país no Governo Reagan e Diretor do Escritório de Política Nacional do Controle de Drogas da Administração Bush. 
(b) fez a transição, começando há cerca de 10 mil anos, de viver diretamente da recompensa proporcionada pela Natureza (através da coleta e da caça) à manipulação deliberada da terra para cultivar alimentos (agricultura), iniciando assim a primeira grande revolução cultural;

(c) produziu as primeiras formas de arte conhecidas (as magníficas pinturas e esculturas rupestres do período desde 35.000 a cerca de 12.000 anos atrás);

(d) enterravam seus mortos com reverência, usando flores (algo em torno de 60.000 anos atrás, na Caverna de Shanidar);

(e) resolviam os problemas da vida à sombra de grandes lençóis de gelo continentais (através do uso do fogo, armas de poder como a lança e o arco e flecha);

(f) fizeram as primeiras ferramentas há cerca de 2.5 milhões de anos, afiando varas e colocando pontas de corte em pedras (e usaram estas ferramentais para criar um novo nicho ecológico para si e para seus descendentes);

(g) desenvolveram linguagem;

(h) e muito mais, durante mais de três milhões de anos de evolução cultural e biológica.

Esse conhecimento, muitas vezes envolvendo desenvolvimentos tecnológicos no passado, além de ter sido usado por meio de novas ciências instrumentalmente incorporadas, simplesmente não existia quando o que consideramos ser o núcleo da civilização "ocidental" tomou forma.

(b) Houve também uma força lateral explosiva em relação às origens da civilização, que agora fazem parte de nossa consciência cultural. Já não podemos ficar satisfeitos com uma história linear da civilização que remonta à história euro-americana, concentrando-se no mundo mediterrânico dos romanos, gregos, hebreus e egípcios, perdendo-se no passado sombrio do Oriente Médio. Junto a essa linhagem devem ser colocadas as linhagens paralelas de outras civilizações ainda existentes como as nossas, inclusive as orientais, particularmente da China e da Índia, com as quais nossos antepassados trocaram e de quem tomaram emprestado, como outros conjuntos de novas disciplinas apenas recentemente revelaram. 
Mais ainda, a suposta singularidade de nossa linhagem deve aceitar ao lado de si os desenvolvimentos das conquistas civilizacionais a partir de fontes não conhecidas antes das idades de exploração e não totalmente até este século. As conquistas dos povos nos nossos próprios continentes americanos são muitas vezes iguais e paralelas às dos nossos antepassados do Mediterrâneo, mas por causa do preconceito colonialista não foram tão reconhecidos até este século. Os moche do Peru tomaram seu lugar ao lado das culturas Inca, Asteca, Tomec e outras da América do Sul que tinham calendário, escrita, astronomia e matemática, irrigação e sistemas rodoviários tão vastos e sistemáticos quanto os nossos antigos.

No equivalente à nossa própria Idade Média, a arte e a metalurgia do Benin eram superiores às que surgiram na maior parte da Europa do mesmo tempo. Muito maior do que qualquer uma dessas conquistas da techné em civilizações paralelas é a domesticação de grãos, que ocorreu na pré-história em praticamente todas as áreas da população do globo.

O que emerge dos estudos científicos modernos é um mosaico de culturas frequentemente intermutáveis. Na verdade, talvez nem estejamos muito certos sobre o que devemos escolher como "nossa" linhagem.

Para tornar o ponto um pouco mais crítico, dois relatórios científicos sobre escavações arqueológicas feitas em 1987 atingiram minha mente com um senso de ironia. Perto de Londres, em uma escavação em um antigo sítio de enterros de cerca de 10.000 anos atrás, duas configurações diferentes para ossos humanos foram descobertas. Aquela em que os ossos foram dispostos em padrões, com artefatos, claramente indicou práticas de enterro. Mas a outra, na mesma camada, era de ossos humanos em uma pilha aleatória, com sinais deliberados de quebra de ossos, especialmente de crânios, o que levou os arqueólogos a teorizar possível canibalismo. Um achado muito precoce no Noroeste norte-americano de aproximadamente a mesma era (a teoria dominante sustenta que a história humana na América do Norte não tem mais de 10.000 a 12.000 anos de idade) confirmou pela primeira vez uma nova teoria sobre fragmentos de obsidiana e cintilação. As pequenas microplaquetas, uma vez pensadas como sendo simplesmente detritos, mas depois teorizadas como sendo pequenas microferramentas (para possíveis usos cirúrgicos ou artísticos), foram encontradas neste local ainda unidas às mãos. Assim, enquanto "nossos" antepassados na Inglaterra estavam (possivelmente) comendo uns aos outros, os antepassados dos Tlingit e Kwakiutl eram sofisticados usuários "high-tech" de ferramentas de pedra! 
Nossa história linear não pode mais reivindicar nem mesmo a superioridade ou primazia de muitas conquistas previamente aceitas. Na matemática, por exemplo, o que antes era a província dos gregos tornou-se agora território da Índia (onde o "zero" foi conhecido pela primeira vez) ou mesmo os babilônios (que usaram o "Teorema de Pitágoras" um milênio antes de Pitágoras). A matemática babilônica, em uma base de sessenta, incluiu não só a maioria dos cálculos da matemática elementar, mas também álgebra e trigonometria e, ligada a um conjunto sofisticado de observações astronômicas, foi capaz de fazer muitas previsões (não, no entanto, tão cedo quanto a do eclipse feito pelos chineses, previamente citado. $)^{2}$

(c) Estas surpreendentes realizações primordiais não só não pertencem às nossas histórias lineares, mas hoje são cada vez mais conhecidas por meio de novas tecnologias instrumentais, que estão recuperando, descobrindo e encontrando novas histórias. Esta explosão do conhecimento é mais um resultado da ciência tecnologicamente incorporada. Em outro exemplo americano, em 1568 os colonizadores espanhóis que se deslocavam pela costa leste fundaram uma colônia na costa da Geórgia, a colônia de Santa Catalina, que permaneceu sem maiores exames até o início dos anos 1980. Usando uma variedade de instrumentos sofisticados (e simples) e técnicas tais como um trado (simples), magnetômetro, fotografia aérea, levantamentos eletrônicos de resistividade e o recém-desenvolvido radar de terra, o sítio começou a revelar uma história bastante diferente da transmitida na história inglesa que dominou sua interpretação. Um resultado transcultural, obtido pela nova ciência interdisciplinar da paleoautópsia, "mostrou que os índios sofreram um declínio na saúde em geral após a conversão de seus modos nativos tradicionais para os costumes espanhóis".

Estamos acostumados a essas notícias. Não nos choca, o que por si só é indício da presença de um passado pluricultural assumido e é também um indicador de um cânone agora explodido. Este conhecimento, mediado como em revoluções anteriores através de tecnologias cada vez mais variadas, abre a inter-relação entre culturas presentes e passadas. Por sua vez, essa inter-relação não pode deixar de enfraquecer, possivelmente descentrar, o facilitado culturacentrismo do novo. Essa é uma condição para o surgimento da pluriculturalidade na contemporaneidade.

\footnotetext{
2 Para uma discussão das descobertas antigas similares veja Humanities, publicado pelo National Endowment for the Humanities, Vol 7, No. 5, Outubro de 1986.

3 KIELL, Matthew. “The Magnetometer That Found Santa Catalina," Humanities, p. 22.
} 
Essa explosão de conhecimento já foi sentida. A sua ironia que surge a partir de nossas metodologias favoritas e da nossa perspectiva científica desenvolvida no Ocidente, mas coloca a própria história que abriu o caminho como mais uma "história" ao lado de muitas outras é parte do que está motivando os debates atuais sobre os currículos básicos. A consciência pluricultural decorrente do cânone ocidental explodido, no qual as antigas pluralidades só agora se tornam conhecidas, porém tomam seu lugar ao lado da pluriculturalidade contemporânea, disponibilizada diariamente por meio de tecnologias de imagem, formou um estrato em nossas sensibilidades pós-modernas. É uma explosão de conhecimento não muito diferente daqueles de Copérnico e Darwin, embora nenhum nome único possa ser associado à descoberta do descentramento da hegemonia "ocidental".

De maneira simbólica, talvez Nietzsche foi o profeta dessa consciência, e esta é uma razão para sua proeminência em tantas discussões filosóficas contemporâneas. Enquanto Nietzsche estava claramente consciente da morte de uma era, ele não estava ciente da configuração do que eu chamo de pluriculturalidade pós-moderna.

Reafirmar agora um currículo central com uma dominação pesada de "textos" ocidentais deve ser visto pela sensibilidade pós-moderna como algo que carrega certa arbitrariedade cultural. Ele exala a uma nostalgia de um universo mais confortável que foi enriquecido linearmente e horizontalmente. Continuando a seguir por mais um momento o paralelismo das explosões do enredo do conhecimento, quem de nós realmente experimenta a nostalgia pela perda do geocentrismo? O universo que emergiu do cosmos do globo ocular revelou-se mais rico, mais vasto e as tecnologias de imagem o retratam com muito mais beleza do que as pinturas medievais que também pretendiam descrevê-lo. Eu não estou tão confiante de que a maioria dos contemporâneos não teria nostalgia sobre a perda do universo antropocêntrico, pré-revolucionário, tanto quanto eles fazem sobre o cosmos. Essa revolução, embora com mais de um século de idade, ainda mantém alguma de sua aura nostálgica, pelo menos em algumas áreas subculturais. Mas estou bastante certo de que a resistência ao que chamo pluriculturalidade é saudável e combativa, um sinal de que a consciência e o debate sobre esta questão realmente começaram.

Existem duas ironias no aumento da pluriculturalidade. A primeira e mais ampla ironia é que o próprio meio pelo qual a cultura tecnológica ocidental se espalhou pelo globo. E o neocolonialismo carregado pelas múltiplas facetas da 
expansão tecnológica, o comércio econômico mundial, o reinado da ciência na educação e a intrusão em cada território previamente isolado das culturas tradicionais tornam-se a própria estrada sobre a qual a consciência multicultural que precede a pluriculturalidade viaja. Mas isso faz parte do lado inferior não detectado da não neutralidade tecnológica.

As tecnologias de imagem são comunicativas, e as comunicações sempre são implicitamente bidirecionais, mesmo nos casos em que há um desequilíbrio de dominância e recessividade. As percepções de Hegel sobre a relação senhor/ escravo e suas inversões também se aplicam às comunicações e às tecnologias de imagem. Isso faz parte de sua ambiguidade essencial, sua forma única de não neutralidade. Mesmo que as tecnologias atuais de duas vias ou interativas fossem mais lentas em seu desenvolvimento do que anteriormente, simplesmente "reproduzindo" tecnologias, seu desenvolvimento atual é apenas o mais recente cumprimento de uma trajetória já existente.

Se a primeira e ampla ironia da dominação tecnológica ocidental é a subcorrente do pluricultural no cenário cultural mais amplo (evidenciado pela explosão do conhecimento observada e também pela aparência da cultura popular como uma única forma de pluricultural), então a segunda ironia é de um tipo mais focado. Refere-se à interpretação específica da ciência tecnológica como um desenvolvimento único e especificamente ocidental. Se essa afirmação é verdadeira e creio que é apenas parcialmente, então, a ameaça da pluriculturalidade tem um significado especial para as formas institucionais dessa ciência tecnológica. Aqui nós vislumbramos uma variante diferente sobre o mito de Frankenstein. O monstro "criado", que cresce poderosamente e acende seu "criador", é temido dentro do contexto da pluricultura de uma forma mais específica.

O medo sentido de que isso seja assim é muitas vezes bastante explícito nos debates atuais no ensino superior. No mínimo, os conservadores entre as faculdades de ciências são rápidos para unir seus irmãos humanistas com respeito à necessidade de restabelecer um currículo de núcleo pesado em fontes ocidentais e muitas vezes contra uma ênfase demasiado pesada sobre os não ocidentais. Se a cultura ocidental é o motivador da forma cultural que conduz a ciência tecnológica, então mantê-la em movimento exigirá aculturação continuada a essa forma de vida. Mesmo o fluxo crescente de emigrantes para esta instituição deve ser assim educado.

Vejo grande parte deste debate, atualmente na reação contra a diluição das tradições ocidentais no ensino superior, como o sintoma de um medo de uma 
revolução cultural que enfraqueceria ou descentraria um passado especificamente concebido. Tenho lançado a cena até este ponto em termos que consideram o reconhecimento da ameaça que a pluricultura representa para aqueles que a resistiriam, mas a sua curvatura como um fenômeno positivo também precisa de um esboço.

A menos que alguém queira ser colocado na posição desconfortável de um equivalente cultural ao ludismo tecnológico, deve-se tomar esta última explosão de conhecimento como sendo potencialmente ao menos tão benéfica quanto as explosões passadas. O conjunto de tecnologias de imagem que transformaram a percepção cultural esta trazendo os mesmos efeitos que aquelas tecnologias que expandiram o cosmos e o micromundo do biológico. Na explosão do cânone (ocidental), é provável que haja um descentramento tão grande como o ocorrido nas revoluções anteriores. Como no conto culinário analógico, a menos que se queira argumentar que o pluripalato é intrinsecamente menos discriminante ou mais exigente que o palato em sintonia com uma única culinária, o resultado quantitativo é obrigado a levar a uma mudança qualitativa.

A pluriculturalidade é, de fato, uma proliferação de pontos de vista. A preocupação daqueles que a veem como uma ameaça é uma preocupação sobre a perda de profundidade singular, mas é a monocularidade que dá a menor profundidade na percepção humana real. Profundidade começa com binocularidade, mas não termina aí. Educativamente, sempre afirmamos isso. Aprender uma segunda língua não só amplia uma perspectiva, mas "binocularmente" nos dá uma maior compreensão da nossa linguagem. Este é o caso que, em nossas tradições passadas, nós temos mantido a posição para favorecer somente aquelas línguas indo-europeias que fossem nossas primas.

O cânone explodido, no entanto, ameaça um tipo diferente de proliferação. Pode parecer muito diverso para o temperamento moderno tardio. Esse temperamento ainda não enxerga com a visão do que chamarei de olho composto da visão pós-moderna. Este olho composto já está instrumentalmente presente no espectro de múltiplas telas encontradas em configurações tão diversas como os centros de lançamento da NASA e as salas de redação da CBS ou da NBC. Diante desses olhos compostos, fica um grupo de telespectadores que coordenam as visões separadas na "mistura" que será tanto a notícia da noite ou o lançamento do foguete. Em última análise, um padrão e uma seleção ocorrem, mas ele é formado a partir da multiplicidade de telas individuais. Arriscando o que eu sei, é devido de ser criticado; o olho composto tem as vantagens desses 
mesmos olhos em insetos, e ele dá um panorama além dos limites mesmo do binocular. Através da instrumentação, pode transformar a visão ainda mais uma vez na experiência humana. Tal visão pode parecer demasiado para o homem de um olho ou de dois olhos nostalgicamente casado com o face a face apenas, mas o mundo instrumentalmente transformado apareceu neste exame de relações de humano-tecnologia em muitos outros disfarces. O mesmo ocorre com a pluriculturalidade.

O olho composto como análogo à pluriculturalidade já é uma "imagem" cultural encontrada no cinema e na televisão. Transformou a visão, mas, como em todas as análises anteriores, é preciso continuar a ter consciência da ampliação e da redução de todas as seletividades tecnológicas. O olho composto refrata, quebra em bits de visão, produz bits de cultura. No início, é difícil discernir o que está sendo visto. Parece haver muitos desses bits para "ler", e a proliferação é muito diferente da "leitura" de um livro.

Talvez seja de esperar que apenas aqueles que usam e aprendem a usar tais tecnologias podem confortavelmente começar a incorporá-las. Além disso, os primeiros usuários são reconhecidamente os usuários da cultura popular. Há um fio de cultura basicamente juvenil, de alcance internacional, que já fez tal acomodação. Ali os índices do pluricultural são claros nas artes fluidas do apelo popular. A moda, tornada uma respeitável disciplina acadêmica desde Roland Barthes, exibe uma rapidez de empréstimos multiculturais ao nível da bricolagem. Empréstimos do Oriente nos casacos e saris nehrunianos dos anos 1960, aos quais foram adicionados dashikis africanos que também foram substituídos no final dos anos 1970 pelos equipamentos paramilitares apropriados aos movimentos de guerrilha. Nos anos 1980, os estilos de alta tecnologia (particularmente o japonês) vieram à tona.

As artes, sempre mais flexíveis e mais rápidas em absorver o novo do que as ciências ou as disciplinas mais clássicas, estão cheias de empréstimos pluriculturais ao nível da música popular. Paul Simon empresta de músicas indianas tradicionais peruanas para algumas de suas canções; estilos como Calypso e Reggae (caribenhos) juntam-se a empréstimos anteriores e adaptações como as músicas do inglês arcaico e ecoam na música folclórica cantada pelos apalaches. Cada uma destas infusões segue padrões isomorfos com aqueles discernidos em transferências de tecnologia.

Em si, essa acomodação popular à pluriculturalidade não mostra nem suas profundidades, nem suas possibilidades. Mas esses também estão lá. Há 
acomodações muito mais profundas para a pluriculturalidade que se tornam inovações e até modos de experiência, assumindo sua própria vida dentro da cultura em seu sentido mais estreito e criativo. No passado, da África vieram as tradições musicais que se tornaram "soul”, "blues" e, acima de tudo, "jazz". Nas artes visuais, as transformações de Benin e esculturas nigerianas no Museu de I'Homme tornaram-se "Les trois demoiselles d'Avignon" na transformação pluricultural de visão de Picasso.

O artefato, também, através das artes e dos ofícios da fabricação de móveis para a arquitetura, são indicadores da pluricultura contemporânea. No mobiliário, os gostos mais antigos para mobília oriental laqueada nunca desapareceram, mas recentemente tomaram emprestado o futon do Japão, adaptado novamente em forma de transferência para os quartos contemporâneos. Frank Lloyd Wright claramente também extraiu em temas orientais as suas variantes modernas, como têm feito outros arquitetos a partir de uma diversidade de tradições. Mesmo as habilidades terapêuticas do contemporâneo não escaparam inteiramente às infusões multiculturais: a acupuntura é parcialmente aceita; as técnicas de meditação associadas aos fenômenos de estresse e hipertensão dos estilos de vida contemporâneos continuam a ter impacto. Essa adaptação multicultural é tão familiar que sua presença provavelmente será esquecida. Constitui uma variedade atual e crescente de pluricultura no mundo da vida contemporânea, já sedimentada como parte de todas as culturas de alta tecnologia.

Dir-se-á que tais adaptações não são "profundas", e isto é o caso, muitas vezes, mas não é exclusivamente verdadeiro. "Superfícies" são, no entanto, fenômenos positivos. Alguns dos primeiros exemplos de escrita, afinal, não são mais do que listas de bens e inventários, mas ainda que escrever não seja uma invenção genuína, toda a literatura agora "profunda”, não seria possível. A pluricultura na sua forma atual é uma invenção da cultura de alta tecnologia. Suas possibilidades ainda não estão totalmente realizadas. Nas ciências físicas de hoje, pode-se dizer que grande parte da ciência de ponta está ocorrendo em interfaces ("ciência de superfícies", como é assim chamada), em que muito do que é significativo ocorre no exterior de dez por cento dos materiais; seus processos de interface conduzem a coisas como a supercondutividade. Talvez esta seja uma boa metáfora para o que deveria ser explorado de forma semelhante no contexto humanístico.

O padrão que emerge nessa forma do mundo da vida é aquele que ( $a$ ) vê uma proliferação de fenômenos (múltiplas variantes culturais), (b) exibe 
estruturas alternativas multiestáveis, (c) implica um campo mais rico de escolha e possibilidade e $(d)$ sugere novas rotas e adaptações. É a visão de mundo do olho composto e não a visão estreitada da visão pré-moderna ou mesmo moderna do passado. É uma visão "cinematográfica”, outra variação do olho composto contemporâneo.

Dentro dos círculos intelectuais, os argumentos sobre uma transição do modernismo para o pós-modernismo são desenfreados. Uma das principais vantagens foi a discussão em torno da arquitetura pós-moderna. Charles Jencks é um porta-voz vocal para tal consciência pós-moderna. Ele afirma que no mundo pós-moderno, o que emergiu é um cognitariado, isto é, uma espécie de cidadão saturado de informações, cujos gostos e sensibilidades dão forma distinta aos tempos. Ele, como aqueles que reagiram contra a presença da pluriculturalidade, reconhece um primeiro sentimento de perda:

Aqueles que escreveram sobre o pós-modernismo notaram a "perda de autoridade", que parece tão característica da nossa época... Sem dúvida, uma era da ciência lançou todas as ideologias em dúvida... Mas a mais abrangente tendência, parece-me, não está tão afastada da crença, mas sim em direção a uma crescente pluralidade de crenças... A paranoia suave é uma característica da superabundância de escolhas e da paranoia generalizada... [ainda] que a mudança fundamental no humor que o mundo pós-moderno trouxe é um novo gosto pela variedade, mesmo que incongruente e paradoxal. ${ }^{4}$

Em suma, o que eu retratei como uma metáfora para o pós-modernismo, o pluripalato, é aqui extrapolado como uma característica da própria cultura do mundo. Jencks comemora:

Talvez a maior mudança no mundo pós-moderno seja a nova atitude de abertura. Não é apenas um gosto pela heterogeneidade que provocou isso, mas também a nova afirmação dos direitos das minorias, da "alteridade"... É claro que muitos indivíduos preferem limitar-se a alguns gostos e desenvolver a discriminação dentro de uma faixa

4 JENKS, Charles. What is Postmodernism? London: Academy Editions, 1987, p. 50,52. Eu descobri este ensaio estimulante depois de ter feito o trabalho básico sobre este capítulo e fui surpreendido por descobrir quantas das propriedades do Zeitgeist que nós, independentemente, havíamos atingido. Jencks, é claro, toma o que estou caracterizando como uma espécie de "superfície" do final do século XX no gosto e na moda e o torna muito mais generalista como sendo uma característica de toda a cultura. 
estreita, e essas lealdades são, de fato, o que faz com que o padrão global de pluralismo opere de forma coerente. Mas, se todos estão limitados a algumas culturas de gosto minoritário, ainda há um gosto residual pelo próprio pluralismo e pelas justaposições que ele implica... A sensibilidade pós-moderna prospera em disposições diferentes das suas e reconhece como a vida seria maçante se tudo tivesse lugar na aldeia do mundo... A situação pós-moderna permite que sua sensibilidade seja um composto das anteriores, um palimpsesto, assim como o próprio mundo da informação depende de tecnologias e energias bastante diferentes das suas. ${ }^{5}$

Embora o que aqui se observou possa parecer, a princípio, uma defesa da pluricultura e de seu "olho composto", esse não é o meu objetivo. A pluricultura é uma aquisição do mundo da vida contemporâneo. É uma das maneiras pelas quais o mundo é tecnologicamente texturizado através da proliferação de tecnologias de imagem. Além disso, se um de seus primeiros resultados é uma cultura popular internacional, isso ainda não mostra suficientemente as possibilidades de ampliação ou reducionistas em exibição plena. Não me parece claro se a cultura popular é uma forma de vida dominante, emergente ou simplesmente uma das proliferações de fragmentos culturais que atualmente descrevem a cena. Tem de tomar o seu lugar ao lado de uma proliferação confusa de tais formas, algumas tão contraditórias como o renascimento dos fundamentalismos, sejam islâmicos ou protestantes. Há uma espécie de onipresença de tais movimentos.

$\mathrm{O}$ que pode ser dito mais positivamente sobre a variante de cultura popular entre a proliferação de fragmentos de cultura é que ela é tecnologicamente experimental. Em uma aceitação quase ingênua das tecnologias, a cultura popular e suas formas de arte jogam com a imagem em seus aspectos produtivos, não "reprodutivos". Isto é assim mesmo junto a um exemplo tão trivial como a MTV, mas mais ainda com os impressionantes efeitos técnicos vistos no cinema de hoje (e vou admitir que muitos filmes contemporâneos são exibições técnicas, ainda que pequenas). $\mathrm{O}$ cinema alcançou alguns resultados genuinamente artísticos e de alta cultura em um meio em menos de um século. Tais usos da tecnologia da imagem, no entanto, ainda são muito jovens para serem capazes de projetar o que suas trajetórias podem ou conterão.

A pluricultura, tanto na sua forma adquirida como na sua incorporação tecnológica, está mais próxima de um começo do que de uma realização. Se

5 Ibid., p. 52-54. 
houvesse, há cinco mil anos, no nascimento do cuneiforme, o equivalente educacional de William Bennett ou Alan Bloom, eu poderia supor que um debate analógico poderia ter ocorrido também. A escrita não parecia ser capaz naquela fase de transmitir a literatura em sentido pleno, mas era apenas um vasto sistema de contabilidade, um conjunto de registros burocráticos e, como uma de suas mais altas conquistas para o futuro da (alta) cultura, um dicionário. Provavelmente não parecia uma aquisição particularmente promissora do mundo da vida suméria. Mas como um meio, a escrita, embora não em forma cuneiforme, transformaria toda a cultura subsequente. A pluriculturalidade, incorporada tecnologicamente no meio das tecnologias da imagem, é, no entanto, um vetor agora adquirido do mundo da vida contemporânea.

\section{B. Carga decisional}

Uma segunda e curvatura relacionada ao mundo da vida de alta tecnologia é o pesado fardo que cada vez mais colocado sobre a decisão, particularmente a decisão consciente. Embora a caracterização de Heidegger sobre a era como uma "razão calculadora" seja parcialmente correta, ela ainda não é toda a imagem. Mesmo o simples giro para os instrumentos digitais melhora tal pensamento calculador ou inferencial. No já citado anteriormente sobre a evolução dos relógios, a redução da leitura do tempo aos seus "dígitos" atuais deixa de fora a representação duradoura do tempo (e qualquer "fluxo" de movimento é substituído pelo "salto" digital da máquina de Turing). Este é também o caso dos instrumentos digitais que medem a aceleração (acelerômetro) ou muitas outras mudanças dinâmicas. Ao contrário dos instrumentos analógicos que exibem múltiplas facetas de tais movimentos, os instrumentos digitais exigem cálculos inferenciais subconscientes para substituir percepções mais instantâneas. Tais inferências são minidecisões.

Em um nível mais elevado, a institucionalização penetrante dos modos de raciocínio calculadamente são parte da "maquinaria" de muitos processos sociopolíticos. Neste exame de uma característica topográfica do mundo da vida contemporâneo, vou desviar-me para o papel de tecnologias de início relacionadas com o início e o término da vida antes de retornar à tecnologia da imagem. No entanto, esses fenômenos existenciais horizontais estão longe de serem as únicas áreas que indicam o peso colocado sobre a decisão. 
Parte da institucionalização do raciocínio calculista vem na elevação das variedades de utilitarismo empregadas na maioria das formas de risco ou práticas de cálculo avaliativo. Já sugeri que muito dos cálculos sobre a tecnologia, se não a maioria, é dominada por tais versões de (quantitativamente orientados) métodos éticos utilitaristas.

Há uma razão para esta escolha. A maioria dos praticantes de processos técnicos são eles mesmos pensadores quantitativos. Situações são colocadas e percebidas como "problemas" que implicam "soluções", cujos meios são processos (calculáveis) "racionais”. Esses filósofos ou eticistas que pensam em termos semelhantes não só se encaixam bem no quadro já existente, mas operam de forma quantitativa semelhante.

Talvez o mais avançado dos casos institucionalizados de tais políticas de tomada de decisão exista em escolas médicas e hospitais. Surgindo a partir de questões de escassez criadas por novas tecnologias de apoio à vida, equipes de ética foram formadas para ajudar médicos a tomar decisões sobre quem deve beneficiar-se em tais situações de escassez. As primeiras máquinas para diálise renal foram especialmente parte deste desenvolvimento inicial.

Estas máquinas eram grandes, complexas, muito caras de operar e de quantidade limitada. No entanto, as doenças tratáveis através da diálise tinham mais pacientes em potencial do que o fornecimento de máquinas poderia lidar. Uma vez que o tratamento foi preferencialmente para os casos críticos, aqueles que não receberam o tratamento foram condenados (prematuramente, mas em uma das ironias em muito da medicina de alta tecnologia, apenas um pouco mais prematuramente) à morte. Médicos, nem sempre reticentes em fazer escolhas de vida e morte, reclamaram; e as escolas de medicina e hospitais logo passaram a ter comitês para fazer escolhas e para auxiliar na escolha. Este era um exemplo prévio da "triagem", agora um termo comum e amplamente aceito e usado mesmo para entrar-se nas salas de emergência dos hospitais contemporâneos.

Eticistas, particularmente se eles forem filósofos, não chegam a um consenso facilmente em como tomar tais decisões. Uma solução popular, frequentemente apresentada um tanto tecnicamente nos jornais, era, basicamente, uma loteria, que ao menos não seria discriminadora contra os pobres, os com baixa educação, ou qualquer outro grupo de excluídos. É irônico que esta escolha artificial transfira apenas a "loteria da vida" para um comitê!

Se a máquina de diálise renal foi uma máquina escassa no início de sua produção, escassez já suplantada por enormes doses de dólares injetadas na 
produção de máquinas miniaturizadas múltiplas, ela era apenas um prenúncio de uma série de operações bem conhecidas e máquinas que complicam ainda mais os problemas de suporte à vida. Corações artificiais, máquinas pulmonares, até exames de tomografia computadorizada e técnicas de Ressonância Magnética Nuclear (RMN) para imagens, todos estes equipamentos colocaram o tecnológico ante a prática médica e fazem parte do que hoje é considerado normal num hospital de alta tecnologia.

Nenhum desses tratamentos aparentemente leves da medicina de alta tecnologia ou de utilitaristas institucionalizados deve ser simplesmente negativo. As decisões cruciais que lidam com o suporte a vida precisam de toda a ajuda que puderem obter. O ponto aqui foi apontar algumas das mudanças que empregam um alto custo à curvatura das ponderações decisionais de um mundo de vida tecnológico.

Voltando-se por um momento para as situações de início da vida e de fim da vida, mostrarei algumas dessas mudanças operadas pela tecnologia ao "decidir a vida". Um exemplo citado na abertura deste livro foi o de "decidir o nascimento". Eu indiquei que o mundo contemporâneo inverte a maneira do mundo antigo de decidir o nascimento. Dominantemente, hoje se escolhe quando começar a vida, ou seja, quando parar de usar as tecnologias de controle de natalidade. A fronteira entre o que seria meramente um processo biológico permitiu espontaneamente seguir seu curso, e o processo cultural tecnicamente incorporado envolvendo uma decisão explícita, mudou. Essa fronteira foi empurrada de volta "para baixo" para o "biológico".

Quando essa decisão é tomada e o processo não começa a tempo ou começa com dificuldade, a gama de opções agora também é expandida. Os tratamentos de fertilidade, acompanhados de diagnósticos mais precisos de onde exatamente a causa reside ou esboçada por variantes impensáveis, pertencem todos ao contexto contemporâneo: a fecundação in vitro, a inseminação artificial (quer com o esperma do cônjuge quer com o do doador anônimo), óvulos transplantados (agora em um espectro inimaginável não há muito tempo ou apenas conceitual); as escolhas expandem-se praticamente ano após ano. Essas técnicas no âmbito das tecnologias de fertilização são claramente outro paralelo com a previamente notada extrapolação da escolha cultural dentro da pluricultura.

Em certo sentido, esta explosão de escolhas é um eco particularizado do mesmo fenômeno anterior em larga escala. 
Em cada uma destas instâncias citadas, o casal, ou mesmo o indivíduo (até agora feminino), pode decidir o nascimento ou o início da vida. Esta decisão é possível em áreas e circunstâncias alteradas de todos os passados humanos. Se vislumbrarmos uma linha, por mais vaga ou nítida que possa ser, entre o que se poderia chamar de espontâneo e de decisivo (entre o reino da "natureza" e o da "cultura", novamente uso esta diferenciação entre aspas para indicar minha inquietação quanto a tal distinção), então é claro que esse horizonte foi deslocado para baixo para o que uma vez teria sido pensado como sendo "natureza espontânea".

A situação é, se for o caso, ainda mais dramática em situações sobre o término da vida. Não há muito tempo, a morte poderia ter sido considerada mais simples ou, pelo menos, melhor definida entre o espontâneo e o agora decisional ou controlável. Ao mesmo tempo, se alguém parasse de respirar (por afogamento, sufocação, inalação de fumaça ou por uma variedade de causas), essa cessação de um processo biológico teria sido considerada um sinal de morte. A mera cessação da respiração já não é considerada assim, de fato, não tentar reanimar através de técnicas tão simples como a reanimação boca a boca ou tão complexas quanto o oxigênio administrado pela máquina; deveria ser considerado negligência.

Da mesma forma, a parada cardíaca (devido a ataque cardíaco, choque, hipotermia e um longo espectro de possibilidades), o que uma vez já foi um sinal "claro" da morte, é agora uma questão de ressuscitação, decidida geralmente através de meios elétricos ou químicos, e mesmo através de meios físicos. Novamente, a fronteira entre os sinais da vida e da morte foi alterada, e a "morte cerebral" de hoje só pode ser decidida através do agora familiar intermédio da instrumentação. O que é "real" é o que se lê no instrumento que é cada vez mais o realismo instrumental da prática médica. Esse mesmo fenômeno também transformou a maioria dos diagnósticos: o que o paciente diz e mesmo a apalpação física no paciente conta menos do que os testes diagnósticos realizados por instrumentos e lidos por técnicos de laboratório ou outras hermenêuticas médicas. Aqui a realidade vista ou percebida através do instrumento é levada um passo adiante, embora dentro do reino do mesmo realismo instrumental encontrado em todas as ciências.

A implicação de todos esses fenômenos é que, no mundo da vida de hoje, eu ou meu substituto (esposa, parentes, advogados) deve cada vez mais decidir sobre minha própria morte. Tais decisões são planejadas até mesmo em testamentos vivos ou outros preparativos cada vez mais "racionais" para decidir sobre 
a morte. Eu experimentei precisamente esse processo na morte de minha mãe há apenas alguns anos:

Ela viveu até os 77 anos de idade, não uma idade extraordinária nos dias atuais, mas sob as circunstâncias, um feito notável. Ela sofreu de artrite reumatoide a sua vida adulta inteira e, nos últimos anos da sua vida, era funcionalmente cega, esclerótica em uma posição sentada, incapaz de mover-se ou até mesmo de alimentar-se a contento, finalmente reduzida à condição de ser cuidada em uma casa de repouso em sua própria comunidade no Kansas.

Meu pai, nessa época, foi vítima da doença de Alzheimer em algum grau de doença e também senilidade. E, assim, na tradição germânica em que fui educado, como o filho mais velho, eu agora tinha praticamente total responsabilidade em seus assuntos. À medida que a saúde de minha mãe se deteriorava, os problemas de circulação gradativamente pioravam em suas pernas, a ponto de que, sem uma amputação dupla, poderia haver gangrena. Fui convidado a decidir sobre a operação. Eu optei afirmativamente, mas com o pleno conhecimento de que o choque para seu sistema enfraquecido seria tal que a recuperação seria arriscada, até mesmo improvável.

Ainda assim, calculadamente, a morte devido a membros gangrenados não era adequada. A operação foi realizada e, por alguns dias, a recuperação pareceu estar em processo. Mas, então, ela foi enfraquecendo e logo poderia existir apenas se fosse alimentada por via intravenosa. Realizou-se uma consulta com todos os familiares, o médico de família e o cirurgião estavam presentes. Voltaria a ser novamente a minha decisão quanto ao curso da ação.

Várias opções foram esboçadas: poder-se-ia ajudar a retardar o processo virtual de "fome" que estava ocorrendo se uma operação direta na artéria fosse realizada para alimentar pelo pescoço, mas com um sistema digestivo falho complicado pelo bloqueio intestinal inferior (fiquei espantado com a progressão dos processos técnicos disponíveis). Depois que essas alternativas foram esboçadas, percebi que o prolongamento de algum nível de vida biológica mínima poderia continuar por algum tempo, mas que essas medidas eram, para mim, muito cruéis para o paciente e, na melhor das hipóteses, paliativos para aqueles que não querem "decidir" uma morte. Assim, eu escolhi uma alternativa que não havia sido mencionada pelo cirurgião, embora tivesse sido discutida com o médico de família: medicação adequada para aliviar a dor, mas sem outros procedimentos cirúrgicos. Isso era claramente "decidir uma morte". Ela ocorreu dois dias depois. 
O que mudou neste contexto tecnológico? Biologicamente, a morte permanece inevitável. Provavelmente, mesmo a duração da vida como tal, não mudou muito a expectativa de vida, que é mais longa no sentido de que mais pessoas atingem idades mais avançadas do que em histórias anteriores, mas a idade-limite dos seres humanos não mudou. Permanece uma fronteira, contra a qual ocorre a morte. Mas ao aproximar-se dessa fronteira, a civilização tecnológica criou aquilo a que eu chamarei uma situação "sartreana", na qual cada vez mais devo "decidir minha própria morte". Esse é o fardo a ser colocado na decisão consciente.

Essa característica da era tecnológica está na base dos debates sobre a eutanásia, suicídio significativo e, no outro extremo do espectro, os meios alternativos de controle de natalidade e aborto. Em cada um desses casos, o próprio poder da decisão é sentido e visto em sua inevitabilidade "sartreana". A única escolha que eu não tenho é a escolha em não fazer uma escolha.

Inverta a situação contemporânea para sua antiga norma, e a situação contemporânea se destacará de forma ainda mais marcante: se, agora, com plena consciência e responsabilidade, eu não determinar em que fase os processos de suporte à vida devem ser interrompidos ("sem medidas extraordinárias", etc.), então estou "decidindo" colocar esse fardo sobre os outros. Eu tenho o "direito" de fazer isso? E, embora ainda não haja uma boa razão para levantar a questão dos "direitos" como tal, nota-se que este é um fardo muito pesado para ser delegado ao outro. No entanto, alguém, não Deus, não a Natureza, terá que decidir na ampliação da gama de recursos de suporte à vida na fronteira das situações que a tecnologia médica criou. Isso é mais do que uma inclinação calculista; é também uma situação existencial "sartreana" na qual devo conscientemente e responsavelmente antecipar e "decidir" a minha morte de alguma forma e de alguma forma nunca antes exigida em situações normais.

A princípio, decidir sua morte aponta para o fenômeno terminal do suicídio, o suicídio em alguma forma como sendo a "norma" para a decisão. Se recusar-se a decidir também é uma decisão, o oposto é decidir, de maneira responsável, os limites da contingência aceitável. Como no campo pluricultural, agora em um aspecto diferente no campo de suporte à vida, a forma do mundo da vida de alta tecnologia prolifera possibilidades que, por sua vez, exigem decisões. Ele levanta a questão da contingência aumentada, mas em um fim de um espectro bastante diferente da atmosfera da vítima da praga do século XIV. Nosso ser-para-morte toma seu vetor dentro da nova forma de contingência aumentada. 
Tal é a curvatura do mundo da vida contemporânea. No entanto, essa curvatura pertence à mesma trajetória geral que vimos em outras situações mais triviais ou menos exigentes. A curvatura indica um alongamento tanto da decidibilidade como da reversibilidade. Esse mesmo fenômeno, avaliado negativamente, seria chamado de incompletude ou falta de encerramento. Ele pertence de forma menos dramática à transformação da escrita através de um processador de texto. Aqui voltamos à tecnologia da imagem como um processo de padronização que pode ser visto em sua curvatura distintiva.

Michael Heim enxerga este vetor na difusão dos processadores de texto, mas ele emprega a isto uma avaliação distintamente negativa:

Essa superabundância de possibilidades [oferecida através do processador de texto] é comparável à descrição de Nietzsche do niilismo como um estado de indeterminação onde tudo é permitido e como resultado nada é escolhido profundamente, autenticamente e existencialmente. Textos genéricos e os fragmentos reutilizáveis assombram toda a escrita texto-processada como uma atração e uma possibilidade constantes. Fragmentos, o experiente usuário aprende, podem ser usados e reutilizados, podem ser encaixados em algum lugar e sem muito esforço. ${ }^{6}$

Aqui, num campo bastante diferente da medicina tecnológica, a multiplicação da decidibilidade é possivelmente vista ainda mais claramente. Não só é um peso colocado sobre a consciência em uma forma "sartreana", mas a falta de encerramento, a constância da dinâmica e a multiplicação de opções que são vistas por Heim como ameaçadoras. Sem necessariamente concordar com a sua avaliação, pode-se entender este aumento de contingência como sendo parte da curvatura contemporânea. Pamela McCorduck, citada por Heim, aponta: "Em outras palavras, o texto eletrônico é efêmero, frágil, maleável, contingente".

Essas percepções corretas, mas negativamente indicadas, obtêm sua negatividade do modelo implícito que valoriza apenas o que dura, é permanente. O processamento de texto, pelo menos antes da "cópia impressa", contrasta com o que é completo e fechado, um livro. Assim, o processamento de texto é visto como uma ameaça à ideia de um livro:

6 HEIM, 1987, p. 211.

7 Ibid., p. 192. 
A escrita digital suplanta a estrutura do livro: substitui o cuidado do artesão por materiais resistentes com manipulação automatizada; desvia a atenção da expressão pessoal para a lógica mais geral dos procedimentos algorítmicos; desloca a estabilidade da formulação contemplativa das ideias em uma superabundância de possibilidades dinâmicas; e transforma a solidão privada da leitura reflexiva e da escrita em uma rede pública onde o quadro simbólico pessoal necessário para a autoria original é ameaçado pela vinculação com a textualidade total das expressões humanas. ${ }^{8}$

Ao contrário de Heim, não me preocupo muito com essa digitalização enquanto tal. Em primeiro lugar, as tecnologias inclinam-se mais do que determinam. Em segundo lugar, o processamento de texto só poderia ter tais efeitos se se tornasse o único processo de escrita. Mesmo que se tornasse dominante, poderia em algumas áreas, sem dúvida, tomar sua posição ao lado das outras múltiplas variantes de textos. Pessimistas já tem previsto o desaparecimento do livro por muitas décadas, mas ainda mais livros são publicados hoje do que em qualquer outro momento da história; e eu, por exemplo, não vejo esse tal enfraquecimento nas obras.

Embora eu tenha aqui justaposto dois exemplos muito diferentes de processamento de texto e processos médicos de suporte à vida, deve ser evidente que a topografia é isomórfica. Decisões múltiplas, ramificações, reversibilidades dentro dos limites em curto prazo, o aumento da contingência em áreas anteriormente mais restritas, todos pertencem a maior ponderação para a decisão que pertence ao mundo tecnológico. Gostaria de saber se Heim veria o mesmo "niilismo" nos processos médicos, se ele preferiria a gama mais antiga e mais restrita de decidibilidade.

No exemplo médico, é claro, ainda há uma área onde esta maleabilidade não existe: permanece que as doenças súbitas, violentas e terminais, tais como cancros de alguns tipos, estão além dos limites de muita maleabilidade médica, enquanto a maleabilidade dos processadores de texto é virtualmente infinita.

Finalmente, em relação a esta forma do mundo da vida, a decidibilidade com seu peso para a consciência pertence à mesma trajetória previamente traçada em relação à pluriculturalidade. Faz parte da mesma contingência, multiplicidade e multiestabilidade. 


\section{Materializando o conceitual}

A ciência moderna difere de suas antigas raízes em virtude de sua incorporação tecnológica. Contudo, se o experimento nasceu através da instrumentação, permanece como uma curiosidade histórica que a outra raiz da ciência moderna permaneceu, até o presente, a única ciência especial que permaneceu em grande parte sem uma incorporação material. Isso também está mudando.

Contemporaneamente e quase apesar de si mesma ser já institucionalizada, a matemática está se tornando um laboratório ou ciência experimental. Historicamente, é claro, houve instrumentos matemáticos na história das máquinas de cálculo simples. E, menos simples, o computador tornou-se o grampeador que agora serve todas as ciências irmãs como um necessário "instrumento matemático".

O computador também é usado regularmente dentro da matemática, mas, entre os puristas, às vezes com desdém e suspeita. Ele permanece sob uma nuvem de suspeita, resistência e até negatividade, considerado como sendo simplesmente uma aplicação ou uma ajuda. Mas o que se tornou conhecido como matemática experimental não é, estritamente falando, uma função dentre as funções de cálculo do computador. É a única maneira pela qual a hermenêutica do computador transforma as funções matemáticas em desenhos perceptivos num retorno à percepção que criou a matemática como ciência experimental. Computação gráfica, ao transformar as projeções numéricas através de cores falsas em padrões perceptíveis, faz o que os cálculos não fazem.

Esta nova tecnologia da imagem recebe apenas uma aprovação rancorosa. Heinz-Otto Peitgen afirma: "A matemática experimental provavelmente nunca será aceita como matemática 'real' pela maioria dos matemáticos, mas para muitos entusiastas, tornou-se mais do que um hobby envolvente, ela é, antes, uma paixão... Essas experiências continuarão para melhorar nossas intuições matemáticas no futuro."

Para aqueles familiarizados com a história da instrumentação, esta reação não parecerá estranha, porque ela tem sido a resposta regular de todas as ciências teóricas previamente "puras" à incorporação tecnológica. Os cientistas da Igreja do tempo de Galileu, talvez legitimamente céticos quanto ao que o então instrumento rústico poderia demonstrar, em seguida, tomaram o partido das perspectivas "puramente" teóricas da razão inferencial.

9 PEITGEN, Heinz-Otto, apud PETERSON, Ivars “Compositions in Chaos”, Bostonia Magazine 59, no. 2, 1985 , p. 35. 
Ian Hacking demonstrou uma história similar no âmbito da biologia. $\mathrm{O}$ microscópio não foi aceito logo de início, mesmo a despeito do fato de que a biologia moderna nasceu em larga escala pela descoberta dos micromundos revelados por meio de tal instrumentação. Os primeiros microscópios eram notadamente difíceis de manusear. Ao final dos anos 1800 Hacking aponta:

\begin{abstract}
Muitas vezes consideramos Xavier Bichat como o fundador da histologia, o estudo dos tecidos vivos. Em 1800 ele não permitiria um microscópio em seu laboratório. Na introdução de seu General Anatomy, ele escreveu: "Quando as pessoas observam em condições de obscuridade, cada uma vê a seu modo e de acordo com o que é afetado. É, portanto, a observação das propriedades vitais que devem nos guiar", portanto, e não as imagens borradas fornecidas pelos melhores dos microscópios. ${ }^{10}$
\end{abstract}

E quando adicionamos o problema de muitas entidades microscópicas serem translúcidas, podemos apreciar o que hoje soa como obscurantismo. Somente depois que os corantes de anilina puderam manchar o espécime e o vidro do sílex foi desenvolvido para tratar a refração é que o microscópio poderia alcançar a transparência próxima necessitada para ser "um meio da visão."

Para que o computador desempenhe o mesmo papel de incorporação que outros instrumentos na história da ciência tecnológica desempenharam, terá que revelar fenômenos anteriormente insuspeitos e novos de maneiras paralelas às "revelações artificiais" do telescópio de Galileu ou do microscópio. Mas isso é o que os gráficos hermenêuticos fazem na matemática experimental. A visualização de topografias de fenômenos matemáticos como fractais, caos e outros processos aleatórios apenas há pouco começou a revelar fenômenos antes insuspeitos. Ao transformar os padrões numéricos na instantaneidade gestáltica da percepção, o padrão começa a sugerir linhas de sobreposição, aplicação e desenvolvimento não suspeitos anteriormente. Aqui, um processo basicamente hermenêutico retorna seus resultados à percepção. Mas enquanto seu resultado é gráfico, a padronização de design vem mais de um homólogo do que um análogo do padrão humano.

Os primeiros trabalhos sobre os fractais revelaram "paisagens" que eram tão semelhantes às geológicas que esses terrenos poderiam ser virtualmente

10 Ian Hacking, 1983, p. 193. 
considerados como representativos. Filosoficamente, os gráficos começaram a indicar um "mundo" tanto determinado quanto aleatório.

Esse tipo de modelagem, é claro, devolve a matemática à proximidade de seu uso histórico nas ciências, como uma aplicação; mas também pode se tornar uma área de fascínio por si própria, mais em consonância com os aspectos anteriormente "puros" da matemática:

Ironicamente, a matemática está provando ser tão interessante que muitos dos matemáticos que agora trabalham no campo estão sendo levados para longe das aplicações físicas que originalmente motivaram os estudos e longe de tentar entender as raízes do comportamento caótico na natureza. [Devaney, um dos proponentes da matemática experimental, diz:] "Estamos descobrindo tantos fenômenos novos e interessantes... É realmente o computador que gera o problema matemático. Você vê algo no papel, você tenta explicar matematicamente, mas você não pode. Então você faz mais gráficos de computador, e continua desta forma." ${ }^{11}$

Embora a matemática usada para esta primeira materialização como ciência instrumental seja simples, a perspectiva é excitante e não é diferente do desenvolvimento da instrumentação anterior na ciência. Usando números complexos, os padrões são gerados projetando as funções de seno e cosseno. O resultado gráfico fornece a maioria das surpresas. As aplicações e os usos, sem dúvida, tornar-se-ão mais sofisticados.

Esta materialização do conceitual, através do instrumento do computador, é um retorno à perceptibilidade. É ainda mais uma encarnação de uma ciência que, em suas origens modernas (com Galileu como nossa figura sintomática), pensou em repudiar o perceptual. Aqueles que inventaram a ciência moderna, ecoando na teoria, mas não na prática, a ciência grega, deveriam ter se recordado da dúvida de Demócrito sobre a exclusão do sensorial: “Ah, miserável intelecto, você obtém sua evidência apenas na forma como nós [os sentidos] fornecemos a você, e ainda assim você tenta nos derrubar. Este tombo será a sua ruína." ${ }^{12} \mathrm{Na}$ prática, no entanto, a ciência moderna incorporou desde o início, ainda que apenas subconscientemente, um novo modo de percepção sensorial incorporado através da instrumentação. Essa incorporação instrumentalizada

11 Ivans Peterson, 1985, p. 35.

12 WHEELWRIGHT, Philip. The Presocratics. New York: Odyssey Press, 1966, p. 182. 
hoje tomou essa nova forma de tecnologia de imagem, que finalmente aparece na menos "perceptível" das ciências modernas.

Essa forma de imagem, no entanto, é muito diferente das tecnologias de "reprodutibilidade" da fotografia precoce, o presumido realismo das primeiras "realidades" cinematográficas ou qualquer outra das presumíveis representações da realidade através de 'imagens'. A computação gráfica são imagens inventadas, uma imagem hermenêutica claramente projetada. É o análogo do retorno da escrita de volta para um tipo de representacionismo pictórico, uma evolução inversa. Para transformar um padrão numérico através do artifício do padrão perceptivo realçado pela falsa cor, seu próprio processo de mancha, análogo ao microscópio primitivo, é um modo produtivo de imagem. A computação gráfica está em uma interface entre ciência e arte, particularmente a arte em seu sentido cinematográfico pós-moderno.

Os artistas têm sido rápidos em aproveitar isto, e a computação gráfica já foi aceita como mídia para as novas formas de arte. Nas últimas exibições bianuais do Whitney Museum of American Art, a televisão e as exposições cinematográficas incorporaram a arte abstrata da computação gráfica. Em abril passado, em Dubrovnik na Croácia, vi uma exposição completamente dedicada a mostrar alguns dos padrões do caos, fractal e imagens holográficas como arte produtiva.

A imagem produtiva, agora estabelecida em tradições variadas no cinema e na televisão, vai muito além da representação e do realismo instrumental em variantes de fantasia inovadoras, agora familiares aos espectadores, bem como àqueles familiarizados com os análogos literários conhecidos há mais tempo. A temporalidade na literatura tem sofrido por muito tempo um transporte hermenêutico imaginativo: o flashback, as sequências de tempo invertidas, os tempos de refração da memória, possivelmente confundidos com os eventos imaginados, são todo o material dos romances modernos. Marcel Proust e James Joyce literalmente transformaram nossos sentidos de tempo biográfico antes que o cinema retratasse os mesmos truques técnicos no visualmente perceptível. No entanto, as tecnologias de imagem do presente retornam essas variações produtivas imaginativas à percepção. A imaginação também se incorpora instrumentalmente. Isso é parte da forma do mundo da vida e sua materialização tecnológica.

Existe um paralelismo social tanto na ciência quanto na arte em reação a tal materialização. Matemáticos desdenhando da matemática experimental possuem certas analogias nas humanidades junto àqueles que se recusam a reconhecem ao cinema ou a televisão o status de arte; contudo, ambas as formas de 
instrumentação transformaram e estão transformando os contextos precedentes dentro do qual a ciência ou a arte foram produzidas e compreendidas. $O$ gênio do pós-moderno, porém, não é eliminar nenhuma das formas anteriores (embora elas sejam reduzidas a alternâncias equivalentes). Cada variante torna-se uma escolha, não $a$ escolha de expressão. Para escrever, pode-se ainda usar uma caneta e defender a sua superioridade como uma forma quase sagrada de produção de poesias, como o meu vizinho Louis Simpson fez recentemente para o New York Times, e sempre se pode desligar a televisão ou se recusar a usar gráficos. Evidentemente, agora não é possível desligar todas as televisões ou livrar o mundo dos computadores; tais escolhas necessariamente tomam seu lugar em um contexto inalterável.

Tecnologias da imagem estão desempenhando um papel tanto nas ciências quanto nas artes que mais uma vez são análogos à aparência da pluriculturalidade. Existe uma proliferação de escolhas; há um retorno à percepção; e uma materialização de ambos em novas formas de incorporações.

\section{Fenômeno oscilatório}

Uma quarta curvatura relacionada ao mundo da vida contemporânea, que chamarei de fenômenos oscilatórios. Estes também estão relacionados com a onipresença das tecnologias de imagem e são as respostas em massa que exageram as ações e reações dos movimentos de massa em viagens e comunicações. Um exemplo dramático de um fenômeno oscilatório foi o surgimento de um movimento estudantil mundial em 1968.

Esta série de eventos foi especialmente dramática para mim, porque a sua ocorrência mais forte foi na França, "les événements de Mai", durante o meu ano de pesquisa 1967-1968 em Paris. Eu tinha assistido a seminários em Nanterre, onde começaram as primeiras greves estudantis; tinha um escritório no Boulevard St. Germain, onde ocorreu o primeiro conflito estudante-policial; e vivia num quarteirão com barricadas em chamas.

Enquanto as greves estudantis francesas eram as únicas catalisadoras para levar uma nação a uma greve geral, movimentos simultâneos ocorreram em outros lugares nos países do Hemisfério Norte. Nos Estados Unidos, houve Columbia, a Convenção Democrata e o episódio da Kent State University; mas também em Berlim, Tóquio e Londres os estudantes foram às ruas e ocuparam 
as universidades. Esta foi uma primeira oscilação internacional e instantânea, um movimento de massa dentro de um contexto de mídia de massa.

O que era especialmente marcante, dramatizado pela experiência de deixar os Estados Unidos antes dos efeitos culturais e políticos de 68, podia ser visto e, retornando depois que eles estavam em pleno florescimento, foi a mudança dramática e oscilatória que havia ocorrido. Agora, mais de vinte anos depois, em outra oscilação caracterizada pela política reacionária e por um renascimento da política-religiosa fundamentalista, podemos ver que alguns dos efeitos culturais de 68 permanecem.

Quando eu parti para a França, era o início do tempo dos cabelos longos para os homens, também apareceram os estilos de roupa sem gravata ou paletó, que eram o traje comum nas universidades. Quando eu retornei, tais estilos mais despojados já eram a moda vigente. Por mais que o cabelo curto masculino novamente domine a cena, nunca mais se tornou a característica universal, porém isso foi apenas pouco antes da revolução cultural dos anos sessenta. Nem as universidades voltaram inteiramente às modas do paletó e gravata de antes, mas exibiram o espectro polimórfico de aparências mais de acordo com o pós-moderno.

Essa primeira oscilação internacional foi um indicador de muitas que seguiriam, respondendo ao impacto comunicacional (e novamente, envolvendo tecnologias de imagem). Essa megaoscilação traria implicações culturais ainda existentes.

Não é preciso olhar para esses eventos de grande escala para ver os mesmos fenômenos exagerados. Respondendo à imagem e informação da mídia, pode-se notar as mesmas oscilações em itens tais como escolhas vocacionais: (a) Em tempo, apenas um pouco mais de uma década atrás, mais de sessenta por cento de todos os estudantes do primeiro ano da Stony Brook apresentavam escolhas, comuns também em muitos outros lugares, e declararam-se aptos para a escola de medicina. Hoje há uma escassez de estudantes de medicina, e com as escolas médicas preocupadas já com a manutenção de padrões elevados com cada vez menos candidatos. Já observamos a escassez ainda maior de estudantes nas engenharias no nível de pós-graduação. (b) Na sequência do Watergate, as escolas de jornalismo foram saturadas com potenciais jornalistas de investigação. (c) Mais recentemente, o que ocorre é a saturação de mestres em administração de empresas. Em todas essas oscilações tem ocorrido um desgaste nos cursos 
de artes liberais mais clássicos, em primeiro lugar nas humanidades, mas agora com similar desgaste de longo prazo nas ciências majoritárias também.

Os movimentos estudantis foram também movimentos juvenis, não alheios ao fenômeno semelhante das oscilações da cultura popular. Há uma localização sintomática da instantaneidade aqui, mas os fenômenos oscilatórios não estão de modo algum limitados à volatilidade da juventude.

A catástrofe tecnológica também traz consigo uma resposta oscilatória. $\mathrm{O}$ tripleto de crises anteriormente observado em Bhopal, "Challenger" e Chernobyl foram seguidos por uma resposta pública imediata e forte que envolveu resultados políticos para as tecnologias envolvidas. O programa espacial dos EUA ainda está se recuperando de "Challenger" com redesenho, investigação e reestruturação da NASA. A recente decisão de desativar Shoreham, uma usina nuclear a poucos quilômetros a leste de Stony Brook, foi em parte devido a Chernobyl (e, mais cedo, Three Mile Island). Falências de negócios relacionadas a fenômenos semelhantes ao de Bhopal ameaçam a Union Carbide (o escudo Dalkon e o A.H. Robins Co. é outro exemplo). Todas se referem a oscilações e aprimoramento da mídia. Estes são os efeitos de anestesiamento após eventos catastróficos. Eles são parte de uma resposta de mercado, mas no que diz respeito à imagem pública, às notícias veiculadas. Os fenômenos oscilatórios também estão intimamente relacionados com o surgimento de tecnologias da imagem.

Esses fenômenos, agora ilustrados como ocorrendo em uma grande escala social, não devem ser surpreendentes para qualquer um que conheça as atuais seletividades estruturais das altas tecnologias. Eles são um efeito social das seletividades de ampliação/redução, neste caso, os dos meios de comunicação de massa. São ainda mais ilustrativas dos maiores poderes das tecnologias contemporâneas (em comparação com qualquer pré-moderna). Eles são os primos relacionados com os meios de comunicação daquele apogeu em poderes de ampliação já alcançados igualmente na indústria de armamentos e nos efeitos climatológicos industriais.

Continuamente, bem diante de nós, essas duas forças tecnologicamente empoderadas tornaram as concretudes negativas universais em possibilidades reais. O poder de provocar a extinção humana autoinduzida através de qualquer um dos dois meios tornou a ampliação tecnológica no poder global que ela é hoje. Do que estamos conscientes e do que devemos ter medos razoáveis. Quais são, se houver, os efeitos anestesiantes? 
No que diz respeito às capacidades de guerra nuclear, o que parece surpreendente para o observador distópico da tecnologia é que, por quatro décadas e meia, nenhum poder maior voltou a usar armas nucleares. Isto é assim, apesar da proliferação de tais armas em aproximadamente cerca de vinte nações. É a consciência da oscilação da extinção que restringe os megapoderes? Certamente a capacidade nuclear tornou a força política clássica parcialmente obsoleta e cria uma espécie de paralisia que derrotou as duas maiores potências (Vietnã para os EUA, Afeganistão para a URSS).

Em vez disso, e de um grande sucesso de poder, há os pequenos sucessos e mudanças que ocorrem dentro dos fenômenos mais recentes do terrorismo e da política desses poderes geopoliticamente menores. O terrorismo é o substituto de pequena potência para o impasse do megapoder, que é impotente. $\mathrm{O}$ ato terrorista é a propagação do cassete analógico em tecnologias de morte. É incontrolável no mesmo sentido, mas continua dentro dos interstícios do impasse maior. É uma tecnologia miniaturizada que se move sem ser controlada entre as megatecnologias que não podem ser facilmente ou simplesmente utilizadas sem a consciência de consequências negativas. Quem disse que o pequeno é o bonito?

Mais imediatamente destrutiva do que a capacidade nuclear tem sido a megacapacidade da poluição industrial sobre o ambiente global. Aqui a lista é longa, complexa e apenas parcialmente isolável para a análise. Atmosfericamente, a poluição por chumbo, chuva ácida e esgotamento da camada de ozônio encabeçam a lista. A poluição do oceano vem em seguida. As focas do Mar do Norte, sucumbindo sintomaticamente à cinomose canina, estão ainda mais enfraquecidas pelo alto teor de mercúrio encontrado atualmente em sua corrente sanguínea (mais de 700 ppm). Aqui, a questão é se os efeitos do amortecimento, induzidos pelo público, serão rápidos, abrangentes ou politicamente eficazes o suficiente para neutralizar o impacto negativo já observado. Há pequenas vitórias. A mais eficaz até hoje foi The Silent Spring, de Rachel Carson, que catalisou a ação para a proibição do DDT (talvez um exemplo-chave da "feminização" da ciência, que vou apontar como um corretivo necessário). Um segundo efeito mais sutil pode ser observado em sinais muito modestos para um resultado imediato. Em primeiro lugar, foi dito que a composição da National Audubon Society ${ }^{13}$

13 N.T.: A National Audubon Society é uma organização não governamental de conservação da natureza, fundada em 1905 na cidade de New York. Conhecida simplesmente por Audubon, é uma das mais antigas organizações dedicadas à temática da conservação da natureza recorrendo à ciência e ao ativismo ambiental. O nome homenageia John James Audubon, um ornitólogo franco-americano que se notabilizou pela publicação da obraBirds of America entre 1827 e 1834 . 
agora excede em número de membros a da National Rifle Association ${ }^{14}$. Se isso é verdade e se um lobby surgir tão eficazmente para a Audubon quanto o que a NRA tem agora, então será possível ver uma mudança de direção rumo à sensibilidade para com a vida selvagem. Da mesma forma, e novamente relacionada à cultura televisiva, a proliferação da programação sobre animais para crianças mudou claramente o campo de sensibilidades das crianças em relação à vida animal. Tão bem-sucedido tem sido que alguns grupos estão mesmo tentando criar a contraprogramação junto às crianças para promover a ideia de "gestão" dos animais, defendendo o uso de armadilhas para fins "humanos". A maioria das crianças de hoje são partidárias das baleias (não está claro se elas também são partidárias do reator).

O fenômeno oscilatório, em instâncias muito mais vastas do que as citadas, faz parte da curvatura contemporânea da consciência sobre e que deriva da sociedade tecnológica. Seus efeitos amortecedores fazem parte do mesmo vetor. Quem tem acesso e quem controla ou usa efetivamente as tecnologias da imagem terá grande responsabilidade, seja quais forem os resultados.

As tecnologias da imagem que têm desempenhado um papel importante em cada uma das formas da sociedade de alta tecnologia, não são as únicas tecnologias que texturizam o nosso mundo. Elas são, no entanto, extraordinariamente significativas, operando como se fossem os elos de um sistema global de comunicações e incorporações culturalmente poderosas da mudança social. Podem ser pensadas como sendo o sistema nervoso da "aldeia global" interligada da terra herdada.

Em cada um dos quatro vetores que delineei, relatei suas formas à imagem emergente - tecnologias que são nitidamente recentes. Essas tecnologias, com capacidades tanto "reprodutivas" quanto "produtivas", estão implicadas em toda a gama de práticas humanas, desde a ciência até as artes, e são cruciais na texturização tecnológica contemporânea. O submundo criado por tais tecnologias é agora uma dimensão adquirida do mundo da vida contando com precisamente aquelas características de familiaridade sedimentada que pertencem a toda experiência dos usos da tecnologia.

14 N.T.: A Associação Nacional de Rifles da América (National Rifle Association of America), ou NRA, é uma organização norte-americana sem fins lucrativos que lista, como seus objetivos, a proteção da segunda emenda da Constituição dos Estados Unidos da América e a promoção dos direitos dos proprietários de armas de fogo, a proteção da caça e da autodefesa nos Estados Unidos. Foi estabelecida em 1871 na cidade de New York. Seu primeiro presidente foi o ex-senador e famoso general Ambrose Burnside. 
Até certo ponto, há uma notável diferença geracional na capacidade de usar e adaptar-se a essas tecnologias e a facilidade com que o fascínio inicial tido por elas se torna familiar em seus usos sociais. E como todas as tecnologias de grande escala, as seletividades ampliadoras são tais que os efeitos globais são frequentes e notáveis. Este conjunto de pistas recaptura a intuição de que a tecnologia contemporânea encontra-se de maneiras distintas diferentes da situação tradicional, que permaneceu mais isolada e regional antes da rede de conexões. Ao mesmo tempo, as características estruturais observadas ao nível de uma fenomenologia e as variantes não expandidas de uma hermenêutica cultural permanecem operativas dentro das relatividades humano-tecnologia. 


\section{8 \\ Epílogo: A Terra Herdada}

Nós estamos agora de volta ao início, a terra tal como a encontramos, amplamente tecnologicamente texturizada, herdada das gerações anteriores de humanos, todas as quais deixaram para trás o Jardim. Antes de partir para as recomendações conclusivas de como cuidar desta herança, recorrerei, uma vez mais, a um conto contemporâneo. Neste caso o acontecimento é real, apresentado deliberadamente, para fins relevantes junto a esta narrativa, por um lado em certo sentido "heideggeriano tardio" e, por outro, com um comentário pós-moderno. A estória está ambientada no final do século XX no sopé do Montalbano, Toscana, Itália, agora quatro séculos depois das primeiras dores do parto do nascimento do moderno:

Há um fogo de madeira de oliveira e carvalho, queimando na antiga lareira no coração da fazenda, sua fumaça rodando em espiral até o topo da chaminé, como teria sido na Idade Média.

Um homem, uma mulher e sua criança pequena apenas puxaram suas cadeiras até a mesa de mármore branco sobre a qual é servido um jantar toscano simples, preparado para a noite fresca de outubro.

Primeiro, há uma massa, recém-preparada com molho de tomate e cogumelos, uma pitada de parmesão, seguida por um prato caseiro de "patate frite", todos com um chianti local e água mineral da fonte próxima no vale. 
A sobremesa é fruta: kiwi e abacaxi, não diferente do que teria agradado os fazendeiros inquilinos que uma vez já arrendaram a moradia de pedra.

Lá fora, sob a lua cheia, as oliveiras estão maduras e as uvas já foram colhidas. Figos frescos e amêndoas ainda permanecem, com o perfume do alecrim, orégano, tomilho e sálvia. (Os tijolos e as madeiras da casa foram agrupados a partir dos restos dos mosteiros e outras ruínas do passado, não diferentemente da bricolagem com que as pedras de Roma foram tratadas no período medieval, carregadas ao longo de toda a Europa.)

(Ele, terceira geração de americanos, cristão secular, germano-escandinavo. Ela, terceira geração secular de judeus, polonesa, russa, austríaca. A criança, quarta geração pós-moderna com características de bricolagem. Mármore, comum aqui, material de construção habitual, também pode ser encontrado na estátua de Davi, em Florença.)

(Massa, inicialmente da China, tomates, do Novo Mundo, cogumelos, um elemento verdadeiramente pós-moderno internacional, encontrado em todas as cozinhas. Batata, novamente do Novo Mundo, a galinha, não industrializada, é genuinamente melhor que a versão norte-americana. Chianti, cujas uvas são colhidas por máquinas e fermentadas em barris de aço inoxidável em alguma cantina local próxima. Qualidade da água controlada com propósitos saudáveis...)

(Obviamente importados, Nova Zelândia e África. Agricultores inquilinos e contrato de trabalho substituíram os servos de sistemas anteriores.)

(Plantação de oliveiras e vinhedos, já com vários séculos de existência, substituíram florestas que anteriormente pertenciam aos aristocratas, cuja terra foi desmatada para deliberadamente diminuir seu poder em detrimento às classes emergentes de comerciantes e guildas. Olivas e uvas estão entre os poucos produtos capazes de crescer no clima agora árido. As ervas mencionadas são típicas da mesma aridez. A lavoura é feita por trator de esteira com disco de arado. O mundo é recolhido globalmente, interconectado pelo comércio, pela história e mesmo pela culinária pluricultural que embeleza a mesa. Na sala de estar podem ser encontrados a televisão e o aparelho de som; no andar de cima, a máquina de escrever eletrônica de alta tecnologia e o processador de textos.) 
A cena descrita foi, naturalmente, amplamente agradável, centrada na intimidade da família e de um evento real. Mas o comentário foi feito deliberadamente para desromantizar a narrativa que imita os cenários de templos gregos, cabanas e oficinas de camponeses e a noção de um mundo reunido no qual a ambiguidade e a complexidade da situação mais ampla é deixada oculta.

Essa visão adapta um ponto de vista mais amplo da paisagem despojada para além do Parthenon, anteriormente descrito, na qual, ao romantismo residual de um Heidegger aqui imitado, percebe-se a necessidade de acrescentar as ambiguidades não ditas relativas ao antissemitismo de muitos dos camponeses e a ameaça do pró-fascismo.

Quando a compilação for reconhecida, é importante que seja reconhecida de maneira plena e multidimensional.

O "mundo" descrito acima não é tão isolado quanto os seus mundos precedentes. Se a narrativa fosse retomada, nota-se que depois do fogo e do jantar, a noite é estruturada por outro conjunto de escolhas pós-modernas. Depois que o jovem Mark é levado para a cama (com estórias contadas a partir de seus livros da Itália, Nova Zelândia e Estados Unidos), seus pais têm as opções de (a) ouvir o rádio estéreo (japonês), talvez uma ópera de Callas reconstituída digitalmente (italiana), (b) assistir à televisão italiana (que, pela manhã, traz notícias da americana CBS), ou (c) retirar-se para a cama para retomar a leitura: ela de Mary McCarthy The Stones of Florence; ele, do Merchant of Prato, de Iris Orego. (Para que o conto não seja tomado de forma excepcional, note que perto de Florença há dezenas de outros professores em licença sabática e, juntamente a centenas de estudantes na Itália para o seu terceiro ano no exterior, em padrões típicos das grandes viagens do mundo transcultural contemporâneo). O casal escolhe ler.

A leitura é reveladora: o comerciante, Francesco Datini, que deixou como legado aos arquivos da posteridade 503 de suas cartas, papéis e livros, traz o período final da Idade Média com grande detalhe e exemplos pessoais. No final dos anos 1300, quando um papa habitava Avignon e estava constantemente em conflito com os italianos do Norte, na véspera do Renascimento, já era possível ver os sinais da era moderna. Este empresário, muito disposto a negociar qualquer coisa, vendendo armaduras e artigos religiosos de todas as partes (mesmo de guerreiros mercenários rivais), viajando a maior parte do mundo civilizado significativo na época ou possuindo postos avançados de negócios como um prenúncio dos conglomerados sobrenaturais do nosso próprio tempo e em um 
tempo, já previamente notado, como tendo estabelecido sua própria revolução tecnológica, revela-nos os seus medos em seu próprio mundo de vida.

Existe a peste, da qual ela dificilmente escapou e para a qual ele perdeu a maioria de sua família, duas vezes. Existem as guerras religiosas, a última das quais finalmente o demoveu de Avignon, permitindo a ele retornar a tempo de ver sua mãe adotiva e a tutora antes dela morrer. Existem os roubos e os perigos da viagem. E existe a fome, que ocorre com surpreendente regularidade, mesmo na Itália do século XIV.

Menos de cem anos mais tarde nascerá, ilegitimamente, como era tão frequente na época, um Leonardo; nascido em 1452, em Vinci, uma aldeia ao redor das encostas de Montalbano, apenas quatro décadas antes do Novo Mundo ser descoberto. Ele se tornaria o próprio símbolo de um polímata renascentista. Ele era claramente um arauto da ciência tecnologicamente incorporada que emergiria no Renascimento. Oportunista ao extremo, ao contrário de seu predecessor toscano, Datini, Da Vinci ofereceu-se a uma série de aristocratas ricos e lordes em guerra. Ele escreveu para Ludovico il Moro uma oferta para construir máquinas de batalha inovadoras:

1. Eu sei construir pontes muito leves e fortes, feitas para serem facilmente transportadas, seja para perseguir ou para escapar do inimigo [...]

2. Conheço técnicas úteis para invadir um território, como drenar água dos fossos e como fazer um número infinito de pontes e passarelas cobertas muito úteis [...] para tais expedições.

3. Item, se no curso de uma ofensiva, a altura de um dique ou a força de um local forem impedir o avanço, eu conheço técnicas para destruir qualquer fortaleza ou outra fortificação que não for construída em rocha contínua [...].

4. Sempre que os avanços falharem, inventarei catapultas, mangais, armadilhas e outros instrumentos incomuns e igualmente maravilhosos. ${ }^{1}$

Esta forma de engenharia científica já se espalhou como praga para o "complexo militar-industrial", ao modo como todo Eisenhower sempre sonhou! (Já observamos que Galileu, mais de um século depois, seguiu o mesmo caminho).

1 CIANCHI, Marco. Leornardo da Vinci's Machines. Becocci Editore, 1988, p. 17-18. 
No século XX a mesma coisa aconteceu. Pouco depois da descoberta da fissão, Werner Heisenberg, procurando recuperar sua reputação, escreveu cartas secretas ao Ministério da Guerra do Terceiro Reich e, mais tarde, organizou uma conferência cujos trabalhos foram intitulados Probleme der Kernphysik, na qual ele propôs a criação de submarinos nucleares, navios de batalha, e um superexplosivo que seria o lançamento da tentativa nazista em construir uma bomba atômica. A diferença com Da Vinci é principalmente estrutural, pois agora a ciência do século XX é corporativa e multiautoral. ${ }^{2}$

O nascimento da ciência renascentista é o nascimento no âmbito de uma roupagem tecnológica e institucionalmente direcionada para as mesmas fontes de financiamento que a Grande Ciência possui hoje. É apenas um mito bem-sucedido do século XIX que nos convenceu de que fora de outra forma. Aqui, também se encontra a dupla relação à tecnologia que ocorre no nascimento da ciência moderna. Ela é incorporada em tecnologias instrumentais, mas conectada em uma matriz de engenharia e ligada aos patrocínios de larga escala disponíveis.

Em um último olhar para as luzes do Vale Florentino, o homem contemporâneo do conto reflete sobre suas próprias preocupações: parte da névoa permanece sobre o vale, que pode ser visto em algum grau todos os dias. A peste desapareceu, substituída por um processo muito mais lento na poluição atmosférica. Os alemães ao norte começaram a perceber que seus dois amores intensos, pelas florestas e pelos automóveis, já chegaram a um estreitamento contraditório. Eles iniciaram ações relativas aos controles da poluição e às gasolinas sem chumbo, mesmo contra as delícias das políticas do Mercado Comum. Mais ao norte ain$\mathrm{da}$, os suecos decidiram que nem sempre se pode ter tanto a baleia quanto o reator $^{3}$ e optaram por eliminar seus reatores (embora, até recentemente, seus vizinhos ao oeste, a Noruega, por exemplo, é um dos países que ainda caça baleias).

Sobre a fome não se ouve mais falar nestas partes agora, e a Itália superou a Inglaterra em produção e no PIB. Mas o homem sabe que no Sul, na antiga colônia italiana, a Etiópia ainda é assolada pela fome, incitada pelo próprio governo indígena que substituiu os colonizadores, pela desertificação gerada pelas práticas agrícolas e pela falta de ajuda suficiente devido às tensões políticas mundiais.

\footnotetext{
2 David Cassidy, um historiador, esta escrevendo agora a história definitiva de Heisenberg durante os anos de Guerra. Ele me forneceu cópias de materiais, que anteriormente eram confidenciais, de autoria de Heisenberg, incluindo correspondências e o Probleme der Kernphysik (Schriften der Deutschen Akademie der Luftfahrforschung, 1943).

3 N.T.: Alusão ao livro de Langdon Winner, The Whale and the Reactor: A Search for Limits an Age of High Technology, Chicago: University of Chicago Press, 1986.
} 
A moral do conto é suficientemente clara: embora nostalgias e romantismos possam em pequenas doses cativar nossa visão, eles também podem obnubilar e algumas vezes obscurecer perigosamente os assuntos. O que é mais amplamente necessário do que estas medicações e um senso profundo sobre a ambiguidade da civilização tecnológica igualmente nos vetores positivos e negativos, que é senso mais amplo de contingência.

Este senso de maior contingência é em si um legado da nossa imersão atual na textura tecnológica. É parte de nossa herança da Terra, uma dimensão da maneira não neutra em que recebemos e retomamos essa herança. Então, a questão mais difícil é como vamos cuidar e lidar com essa herança. Ela pode ser desperdiçada; poder ser conservada; e pode até ser aumentada.

O que devemos fazer para optar pelas duas últimas alternativas? Em parte, o projeto deste livro é precisamente uma recomendação preliminar em resposta a essa pergunta. É preliminar, no sentido filosófico, como uma tentativa séria de entender a compreensão mais adequada da forma e da estrutura de uma civilização tecnológica. É, nesse sentido, uma abordagem filosófica muito clássica ao delinear um quadro de compreensão. Tentei ser crítico e, no entanto, sem encorajar nem uma rejeição absoluta nem uma aceitação cega do nosso estado de coisas herdado. Mas, nesse processo, é filosoficamente inevitável que haverá perspectivas de avaliação implícitas que emergem simultaneamente a partir da própria investigação. É a estes que eu me volto para o fechamento deste projeto.

\section{Recomendações de manejo para a Terra Herdada}

\section{A. Conservar a Terra}

Um dos principais subtemas deste projeto foi o reconhecimento de que os altos poderes de ampliação da tecnologia têm agora uma força de impacto geológico. Combinada com o que permanece uma ética dominantemente expansionista em relação à natureza, minha primeira recomendação deve ser uma ética de conservação em todo o mundo. Esta é, em minha opinião, a necessidade mais abrangente e urgente em resposta à relação frequentemente negativa que hoje a civilização de alta tecnologia colocou sobre o meio ambiente.

Enquanto os valores ocidentais dominantes não podem escapar da culpa, eles não são a única fonte do problema; a culpa precisa ser distribuída muito 
mais amplamente do que isso. J. Donald Hughes, em sua crítica mordaz sobre a falta de uma ética ambiental a todas as civilizações próximas que rodeavam o Mediterrâneo em tempos antigos, vê parte da culpa no abandono de um animismo ainda mais antigo. Quaisquer que fossem os modos de fuga do animismo, seja o grego, o hebraico, ou o romano, os resultados eram sempre os mesmos para a Bacia do Mediterrâneo. Não é evidente que as formas mais antigas de religião eram, no geral, melhores em qualquer aspecto.

Outras culturas não ocidentais têm frequentemente sido todas muito destrutivas do ambiente na prática. Uma das tribos nativas da Nação dos Iroqueses, com base na crença de que os animais tinham linguagem, e que eles fofocavam sobre qualquer viagem secreta ou rumo à guerra, matariam sistematicamente qualquer animal durante o percurso para que eles não informassem sobre seu paradeiro ao inimigo. Eu já observei antes a extinção sistemática das aves sem asas em toda a maior parte do Pacífico devido à marcha ao oeste das várias tribos dos meus navegadores favoritos. Mesmo entre as sociedades tradicionais, com demasiada frequência, parece que as sociedades delicadamente balanceadas, como o aborígene australiano ou os inuítes são exceções e não a regra na rigorosa prática conservatória.

O que permitiu que isso ocorresse até hoje reside na fecundidade da terra e em populações pequenas para não sobrecarregá-la. Sociedades que se utilizam da coivara poderiam continuar a existir, mas apenas em uma selva que poderia se recuperar após eles partirem em suas viagens e apenas na condição de que a população daqueles povos com tais práticas destrutivas permanecessem pequenas o suficiente para que a recuperação ocorra em tempo hábil.

Por outro lado, nosso próprio histórico não tem sido invariavelmente negativo. Heidegger estava certo sobre um aspecto da cultura camponesa europeia. Eles se preocupavam com a terra como solo. René Dubos apontou em Wooing the Earth que um resultado da melhoria das práticas agrícolas europeias após a invenção do arado e a descoberta da agricultura de rotação foi a produção real de um solo rico em nutrientes. Na França, esse solo melhorado tornou-se propriedade do agricultor arrendatário que fez a modernização e poderia ser levado com ele, caso ele se mudasse. Da mesma forma, uma das poucas áreas do mundo a ser seriamente reflorestada, após o virtual desmatamento, foi New England, nos Estados Unidos. Há mais floresta agora nos estados do norte em New England do que em qualquer momento desde que os colonizadores chegaram pela primeira vez. 
Há dois séculos, 70\% da terra em Rhode Island tinha sido desmatada da floresta que uma vez a havia coberto quase completamente. A floresta primordial tinha sido transformada em terra agrícola pelos colonos brancos originais. No final do século XIX, no entanto, as fazendas menos produtivas foram abandonadas e as árvores retornaram tão rapidamente que menos de $30 \%$ do estado permanece desmatado hoje. ${ }^{4}$

Um efeito colateral foi o exitoso retorno migratório ou reintrodução de muitas espécies autóctones de animais que não eram vistos há um século ou mais. Em Vermont, minha própria casa de veraneio é agora um recanto para perus selvagens, pássaros pescadores e ocasionalmente até coiotes que se adaptaram à vida na floresta.

Enquanto a notícia geral permanece que o desmatamento nocivo está claramente avançando mais rapidamente do que reflorestamento, movimentos de conservação com algum sucesso estão ocorrendo no meio dos setores mais populosos do mundo. A Europa, por exemplo, conta com as áreas geográficas mais densamente povoadas (pessoas por quilômetro quadrado) na face da terra e, no entanto, quando tentativas reais são feitas para controlar ou reverter os efeitos negativos, pequenos sucessos podem ser notados:

$\mathrm{Na}$ área de Londres, o rio Tamisa foi extremamente poluído, como atestado por Michael Faraday em carta muito divulgada pelo Times em 1855. A abundância e a variedade de peixes tinha começado a diminuir quase dois séculos antes [...] e apenas enguias sobreviveram em certas áreas por volta de 1855. Em 1976, porém, havia oitenta e três espécies de peixes no estuário, e mesmo o salmão foi capturado em Londres pela primeira vez em aproximadamente 150 anos. ${ }^{5}$

Distribuir a culpa, entretanto, não é a mesma coisa do que deixar as próprias tradições de fora com base em circunstâncias atenuantes. Eu me juntei a Martin Heidegger, Lynn White, Jr., J. Donald Hughes, René Dubos e muitos outros que colocaram uma grande parte da responsabilidade na conta de algumas de nossas crenças dominantes, sejam culturais ou religiosas. Elas devem ser modificadas se com isto as condições para uma verdadeira ética de conservação forem encontradas. Essas crenças incluem (1) a crença de que a terra é principalmente um bem de consumo para o privilégio dos humanos; e (2), estreitamente 
ligada, a crença de que existe uma grande e valiosa diferença significativa entre os seres humanos e o resto do reino animal, de modo que nossa precedência é justificada em praticamente todos os casos.

Contribuindo para o fortalecimento destas crenças está uma longa e interligada história que não inclui apenas uma vertente de crenças de predominância judaico-cristã, mas também a vertente de interpretação sobre a terra que advém do antigo atomismo grego, o qual reduz a terra de um modo diferente a uma espécie de matéria aleatória (que pode, em combinação com a crença religiosa, tornar-se a maneira de subjugar essa terra como bem de consumo).

Se a visão dominante é tanto redutora quanto dominadora, eu ainda não estou convencido de que qualquer revivificação do animismo antigo ou de seus relativos seja uma opção, ou seja, mesmo algo desejável.

Langdon Winner, em sua apreciação usualmente perspicaz sobre a ambiguidade, colocou muito bem o dilema tanto no título quanto na experiência de seu livro The Whale and the Reactor. Podemos ter ambos? Em uma experiência que Winner compara à epifania de Henry Adams em "The Virgin and the Dynamo", mas, inversamente, ele acredita que a escolha é cristalizada:

Olhei para uma vista que me deixou cambaleando. Debaixo de nós, aninhado nas margens de uma enseada minúscula, estava o gigantesco reator nuclear, ainda em construção, um enorme bloco retangular marrom e duas cúpulas brancas. Em conjunto, as cúpulas pareciam ligeiramente obscenas, como os seios salientes de uma deusa gigantesca que havia sido enterrada cuidadosamente na areia pelos escorregadios escavadores [...] Naquele momento, outro olhar me chamou a atenção. Em uma linha com o reator e a Diablo Rock, mas muito mais distante para dentro ao mar, uma baleia-cinzenta emergiu de repente à superfície, expeliu através da narina um jato de vapor muito alto, e desapareceu então abaixo das ondas. Um silêncio sobrepujante se abateu sobre mim. ${ }^{6}$

Existe uma assimetria nesta questão. Nós podemos ou poderíamos promover substitutos para o reator. Pode haver outras tecnologias; e pode haver outras contextualizações multiestáveis de tecnologias; mas nós não podemos substituir as baleias. Isto se aplica igualmente para quase metade das espécies sob ameaça

6 WINNER, Langdon. The Whale and the Reactor: A Search for Limits an Age of High Technology. Chicago: University of Chicago Press, 1986, p. 165-66. 
devido às práticas de desmatamento na floresta tropical. Em um artigo, "No Dinossaurs This Time”, uma questão é posta:

'A biota da Terra agora parece estar entrando em uma era de extinções que pode rivalizar ou superar em escala o que ocorreu no final do Cretáceo, há cerca de 65 milhões de anos.' Esta visão sombria e mais do que um pouco surpreendente foi expressa por Paul Ehrlich, da Stanford University, em um recente encontro sobre a dinâmica da extinção. O desenvolvimento desenfreado, incluindo o desmatamento urbano, agrícola e florestal, é a causa do colapso iminente, diz ele. ${ }^{7}$

E embora eu aprecie os argumentos da "floresta" contra o "deserto" que os biólogos utiliza atualmente para afirmar que se nós perdermos esta riqueza das variedades da flora e da fauna, nós perderemos também muitas "soluções" potenciais para o futuro da farmácia do mundo, o que permanece apenas uma lamentável variante da visão da terra como sendo um bem de consumo. Certamente a terra é mais rica do que um potencial farmacológico, mas nós podemos ver isto sem retornar ao animismo obscuro de nossos ancestrais?

Ver a necessidade de uma ética de conservação mundial com apoio jurídico para os seus aspectos particulares está longe de ser uma recomendação única. Tem sido chamada e reconhecida repetidamente como uma necessidade. Também não é suficiente queixar-se de que, enquanto existir a estrutura atual de estados-nação, corporações multinacionais e necessidades de nações em desenvolvimento, nenhuma ação significativa resultará. Mais profundas, mas mais difíceis de lidar, são as questões culturais/filosóficas que definem o contexto no qual o debate ocorre. Enquanto a natureza é vista como um instrumento redutivamente instrumental para uma humanidade elevada acima de todos os seus vizinhos biológicos, ao modo de nossa atual mitologia dominante com tudo o que resulta dessa mitologia, provavelmente não haverá motivação suficiente para a mudança. Nem argumentos instrumentais nem estéticos, particularmente na cultura moderna, a estética sempre ocupa o segundo lugar das posições utilitárias que vão influenciar a sensibilidade.

O problema é que qualquer maior mudança da gestalt nas sensibilidades terá que ocorrer dentro das culturas tecnológicas. Se a hermenêutica cultural deste livro está sugestivamente correta, então não há cultura maior externa com força suficiente para nos convencer de sua superioridade. Não há frota chinesa

7 LEWIN, Roger. “No Dinosaurs This Time”, Science, vol. 221, September 16, 1983, p. 1168. 
no nosso horizonte. Isso é meramente a rejeição secular de qualquer "deus" salvador como provável ou possível.

O cenário mais amplo parece, então, sombrio em relação a qualquer persuasão global imediata sobre a promulgação de uma ética de conservação. Mas dentro dos interstícios existem pequenos indicadores positivos que podem ser aprimorados. Primeiro, a criação de redes em todo o mundo através de várias tecnologias existentes é uma condição para qualquer mudança global genuína. Essa rede continua a ser um fator simultâneo ao "domínio" tecnológico. Segundo, como o fenômeno demonstrado na pluriculturalidade, um efeito imprevisível de qualquer ligação é o fluxo bidirecional de influências culturais ao longo dessa rede. Um efeito já detectável é o enfraquecimento de certas tradições dos valores precisamente ocidentais que prevaleciam. A pluriculturalidade não indica nada como a ascensão e o domínio de algum modelo cultural não ocidental específico. Embora muitos gostariam de ver a adoção de várias crenças orientais diversas como uma forma de equilíbrio para a atual tensão dominante ocidental, eu não vejo isso como uma probabilidade em parte alguma. Esse enfraquecimento, enquanto condição de qualquer mudança definitiva na sensibilidade, também não necessariamente pressagia uma melhora ou um agravamento da situação. O surgimento de fortes tendências pós-modernas da cultura popular é, no máximo, ambíguo e ainda muito difícil de ser medido em relação a uma formação cultural mais particular.

Dentro das culturas mais amplas, em grande parte juvenis, do pós-modernismo, existem alguns indicadores menores de direções positivas. Já citei as empatias animais, às quais devemos acrescentar uma consciência de interconexão ecológica muito mais forte apresentada pela maioria das crianças educadas na televisão de hoje. Outro fator positivo é que parece estar sumindo ou ter desaparecido em sua maioria, por meio da consciência formada através da educação televisiva, a antiga forma de estereótipos negativos associados a certas espécies animais. (O "grande lobo mau" pertence agora mais claramente aos contos de fadas, menos aos lobos e seus habitats, o que também é um fator positivo na verdadeira educação científica disseminada pelos meios de comunicação de massa).

Estas formas de consciência empáticas e ecológicas tem um efeito secundário no enfraquecimento das crenças que justificam um distanciamento entre o humano e seus vizinhos animais. Além disso, elas também ajudam precisamente o nosso lado materialista do passado a emergir. As próprias ciências que des-animaram (e des-antropomorfizaram) tanto o animal quanto o humano agora 
estão gradualmente reduzindo os aspectos subexperienciais do hiato humano/ animal. Isso está ocorrendo igualmente na biologia e na psicologia.

Nós temos condições agora de reconhecer um fenômeno tal como uma "cultura animal", comportamentos aprendidos e repassados similarmente às culturas históricas humanas, ao menos dentre os animais superiores. Lobos, antes desprezados, são reconhecidos como tendo padrões sociais específicos transmitidos à sua progênie através de comportamento social. As baleias mudam suas canções (elas teriam uma cultura popular pós-moderna?) entre os anos de suas migrações, indicando algo muito mais forte do que as repetições inatas. O uso de ferramentas, padrões de primatas muito mais próximos aos nossos comportamentos, até mesmo habilidades de protolíngua e, abaixo do nível de comportamento, sobreposição genética (de 99 por cento entre humanos e primatas), tudo isto diminui a distância biológica entre nós e nossos vizinhos animais.

Apesar desta modificação da lacuna entre nós e os animais, ainda há fortes evidências de que estamos dispostos a modificar nossos próprios padrões comportamentais em relação aos animais. As notícias desta manhã, entretanto, traziam as recomendações do estudo da National Academy of Science (NAS) contra qualquer mudança na lei a respeito do controle do uso de animais em experiências de laboratório relacionadas à pesquisa. Eu não estou aqui argumentando que os que defendem os direitos dos animais têm ou não têm um argumento contra o establishment da ciência; estou apontando que, ao mesmo tempo em que a noção de nossas fronteiras de vizinhança está mudando, as práticas da ciência estabelecida estão sendo defendidas como necessárias. (A NAS muitas vezes age de uma forma semelhante à AMA (American Medical Association) em relação à medicina, isto não deve causar surpresa). No entanto, será visto que enquanto o reino animal continua a ser parte da natureza "bem de consumo", a diminuição da distância pode fazer pouca diferença por si só.

Se há pequenos sinais de mudanças no conjunto das relações humano/animal, será que o mesmo se aplica aos nossos conceitos de natureza? O sentido dominante e redutor da natureza permanece penetrante. Pode o nosso conceito de natureza ser des-instrumentalizado sem ao mesmo tempo retornar a alguma forma de animismo? Existem indicadores internos que possam modificar a atitude dominante atual em relação à natureza? A resposta não é fácil, nem há fugas fáceis do cenário atual. Obviamente, qualquer consciência ampliada da interação humana com o sistema ecológico da Terra é positiva. E, além dos ataques à "Hipótese de Gaia", que ainda se associam ao antropomorfismo, o 
conceito que vê uma interligação entre as dimensões biológicas e não biológicas da terra parece provável e plausível para o futuro da compreensão do planeta. No mínimo, ver a civilização tecnológica como uma espécie de força "geológica" ativada biologicamente deveria ser agora evidente. Com ou sem a metáfora da "Natureza nos dizendo algo", a autorreverberação de ações ambientais negativas é mais amplamente conhecida.

Ainda assim, não existe um modelo pós-moderno, esperançosamente mais rico, que possa competir por um reconhecimento mais amplo aqui sem recair em alguma associação nostálgica com visões religiosas ou pré-científicas mais antigas sobre a natureza. Novamente não estou discutindo contra aqueles que introduziriam elementos de fragmentos culturais passados, que é uma das próprias tendências do pós-modernismo sobre as quais eu argumentava e que caracterizavam a pluriculturalidade, mas a bricolagem permanece teoricamente insatisfatória.

Assim, tão urgente e tão claro como o estabelecimento de uma ética ambiental conservacionista promulgada em um acordo de leis internacionais ou multinacionais possa parecer, também parece improvável que um resultado tão esclarecido ocorra imediatamente. A estratégia, então, deve permanecer intersticial e fragmentada.

\section{B. Desmitificando (e desmasculinizando) a Ciência Tecnológica}

Em seu sentido crítico, a hermenêutica tem uma função desmistificadora. No contexto dos programas de abstenção de nossa compreensão da tecnologia, tenho repetidamente tomado uma visão modificada da ciência como ferramenta conceitual da cultura tecnológica em seu sentido de alta tecnologia. E, se mudar ou remodelar uma ferramenta tem efeito, então se pode esperar que uma ação intersticial significativa possa vir a ser direcionada para esse fim. A história e a filosofia da ciência sofreram mudanças radicais nas últimas duas décadas e uma série de críticos começaram a chegar a um consenso sobre vários aspectos importantes da compreensão e interpretação da ciência contemporânea. Eu denominaria a dimensão crítica deste consenso algo que visa desmitificar mitos exagerados sobre a ciência.

O surgimento da educação científica tem sido visto como essencial para a manutenção da cultura tecnológica; a ciência é o conjunto factualmente mais 
dominante de disciplinas dentro da academia; e há uma crença quase religiosa que adere à ciência como socialmente salvacionista; estas funções estão todas profundamente enraizadas na cultura de alta tecnologia. A desmitificação tem como parte de sua tarefa equilibrar e, em alguns casos, reduzir as distorções que podem ocorrer através dos mitos atuais sobre ciência.

Em seu esboço mais amplo, o consenso emergente concorda que a ciência deve ser vista como uma das muitas atividades intelectuais e culturais humanas; e como algo que deve tomar seu lugar (mais democraticamente) entre seus pares. Esse não é o papel que ela desempenha atualmente em qualquer um dos países tecnológicos avançados, particularmente o nosso. Especialmente dentro da educação e, mais especificamente, dentro das grandes universidades de pesquisa, a ciência e seus parentes "aplicados" associados exibem o papel predominantemente dominante. Isso é evidenciado econômica e politicamente. Em nível nacional, um pequeno indicador é o tamanho relativo e a estrutura de apoio entre a ciência, as artes e as humanidades, como se vê no National Endowments. O orçamento de quase US\$ 2 bilhões da $\mathrm{NSF}^{8}$, programado para ser duplicado pelo presente regime, avilta os aproximadamente US $\$ 135$ milhões do $\mathrm{NEH}^{9} \mathrm{e}$ $\mathrm{NEA}^{10}$, respectivamente. Acrescente-se o apoio da indústria e o apoio das forças armadas, às vezes oculto, mas cada vez mais explícito, apoiando grande parte de muitos orçamentos de pesquisa acadêmica (ver o gráfico a seguir), e note-se que não há de forma alguma nenhuma aristocracia ou nobreza aqui.

Parcela proveniente do Departamento de Defesa no total do Financiamento Federal (Ano Fiscal de 1985) ${ }^{11}$

8 N. T.: NSF ou National Science Foundation é uma agência independente do governo dos Estados Unidos que oferece suporte fundamental para a educação e pesquisa em todos os campos não médicos das ciências e engenharias. Foi fundada em 1950 "Para promover o progresso da ciência; para melhorar a saúde, prosperidade e bem-estar da nação; e para assegurar a segurança nacional”. Em 2016 o orçamento da NSF foi de US\$7.724 bilhões.

9 N. T.: NEH ou National Endowment for the Humanities é uma agência independente federal do governo dos Estados Unidos, estabelecida pela National Foundation on the Arts e pelo Humanities Actde 1965, dedicado a dar suporte à pesquisa, educação, preservação e programas públicos nas humanidades. Em 2016 o orçamento da NEH foi de aproximadamente US\$147.949.000 milhões.

10 N. T.: NEA ou National Endowment for the Arts é uma agência independente do governo dos Estados Unidos que oferece suporte e custeio para projetos de exibição artística de excelência. Ela foi criada por um ato do Congresso Americano em 1965 como sendo uma agência independente do governo federal. Em 2016 o orçamento da NEA foi de aproximadamente US\$ 147.949.000 milhões.

11 Como os dólares militares no Campus distorcem a pesquisa científica. Fonte: TUCKER, Jonathan B. "Scientists and Star Wars”, em Union of Concerned Scientists, Empty Promise. Boston: Beacon, 1968; e HARTUNG, William; NIMROODY, Rose. “Star Wars: Pentagon Invades Academia”, CEP Newsletter, Council on Economic Priorities, January 1986, Tabela 1. 


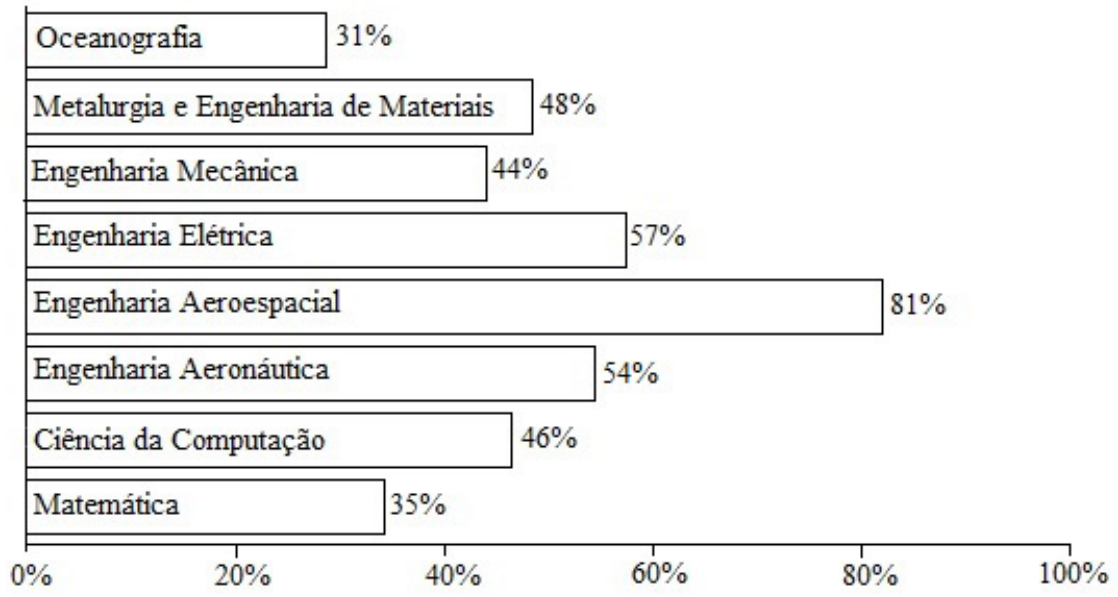

Então, quando se adicionam os aproximadamente US\$ 8 bilhões do orçamento destinado ao National Institutes of Health, que apoia amplamente o establishment da Biologia, nota-se que entre as disciplinas existe uma disparidade muito contundente de suporte maior do que a existente entre os tamanhos relativos de Davi e Golias. Nunca nem se ouviu falar de Golias simplesmente abandonando voluntariamente sua posição superior.

A maioria dos Davis que desafiam os Golias tem um final triste, mas nas estórias algumas vezes eles ganham um ou dois pontos; e contar estórias é o que os historiadores, filósofos e críticos literários sabem fazer de melhor. É neste campo da interpretação e crítica que a reformulação pode ocorrer. Essas críticas assumem várias formas. Eu não ensaiarei aqui todas elas, mas vou me concentrar somente em algumas das mais pertinentes e novas formas de críticas que a ciência enquanto instituição vem sofrendo.

Meu primeiro exemplo do consenso desmistificador emergente vem de uma nova virada em uma controvérsia focada entre ciência e filosofia da ciência, que apareceu a partir de uma batalha sobre um comentário possivelmente comissionado, "Onde a Ciência falhou", na revista Nature, uma das mais prestigiadas das revistas científicas britânicas. É uma forte evidência de que a narrativa davidiana se faz sentir.

Já agora nos anos 1990, é evidente que uma revolução intelectual de grande porte abrangendo muitas disciplinas começou a tomar forma no início dos anos 1960. Nas humanidades, este foi o período do surgimento de todo um espectro 
da "teoria", o nascimento de muitos métodos agora chamados de "Nova Escola". Incluía o impacto da fenomenologia e hermenêutica do pós-guerra, o estruturalismo, o avivamento dos métodos neomarxistas e neofreudianos e, posteriormente, as técnicas feministas e desconstrutivas. Mas ao mesmo tempo, embora quase que de forma isolada das grandes tendências continentais acima citadas, surgiu o que eu chamarei de Nova Filosofia da Ciência. Na América do Norte, esta nova interpretação da ciência centrou-se em A Estrutura das Revoluções Científicas (1962), de Thomas Kuhn. Na Grã-Bretanha, uma reformulação menos radical da interpretação científica foi desenvolvida por Karl Popper.

O que pode ser chamado de Velha Filosofia da Ciência tendia a interpretar a ciência de uma forma descontextualizada, focando quase unicamente sobre sua lógica, proposições e procedimentos racionais. Como resultado, a ciência enquanto instituição pareceu ser a-histórica e a-cultural, e o mais relevante para uma investigação da tecnologia, claramente distinta e frequentemente separada de suas tecnologias.

Cada uma dessas características era desafiada por variáveis sobre a Nova (história e) filosofia da ciência. Esses novos movimentos exigiam uma interpretação da ciência que a tornasse um fenômeno situado, um fenômeno com-textualizado. Sem entrar aqui nas particularidades desta "mudança de paradigma" no que diz respeito à interpretação da ciência, apenas observo que temos duas décadas e meia de contestação dentro da história e da filosofia da ciência junto aos círculos científicos em que os defensores da Velha filosofia da ciência rotulam epítetos de "relativismo" e "ideologia" aos proponentes da Nova. Mas, apesar disso, é justo concluir que a Nova filosofia da ciência tem garantido seu lugar com muita propriedade em uma ampla linha de frente. Muitas das ciências agora interpretam seu próprio trabalho de forma kuhniana e pós-kuhniana. A Nova filosofia da ciência, davidiana em sua hermenêutica inicial, não havia matado, mas ao menos ferido o velho gigante.

O que eu estou chamando aqui a "controvérsia da Natureza" é parte de uma reação a esta batalha, mas em uma nova roupagem. Os autores não ressuscitam os antigos filósofos da ciência como seus defensores, embora eles assumam algo próximo a uma postura positivista precoce. Em vez disso, entretanto, atacam os resultados presumidos da batalha com respeito ao que eles percebem como um apoio público erodido para os esforços científicos. Essa questão motivadora foi o declínio dos gastos públicos com a ciência na Grã-Bretanha, particularmente nas universidades, ao longo da era Thatcher. Os autores observaram que o clima 
público para gastar com ciência começou a esfriar nos anos 1970. Eles têm colocado parte da culpa, até mesmo a parte mais profunda da culpa por este declínio de apoio, na conta da Nova filosofia da ciência: "nosso objetivo é identificar e esforçar-se para combater o que consideramos o mais fundamental, e, no entanto, a causa menos reconhecida da situação atual da ciência, não só na Grã-Bretanha, mas em todo o mundo." ${ }^{12}$ Invejando a transmissão pública de programas que discutem questões de objetividade na ciência e que implicam críticas por posições da Nova filosofia da ciência, os gêmeos Bennett-Bloom observaram:

Estes eram ataques contra a objetividade, a verdade e a ciência [...] Pelo menos na Grã-Bretanha, as repercussões desses argumentos equivocados já estão acontecendo. Cientistas em outros países estão devidamente avisados.

Referir-nos-emos a essas ideias errôneas e nocivas como as posições antíteses epistemológicas, posições (não) filosóficas que são contrárias às teses tradicionais e bem-sucedidas da filosofia natural. ${ }^{13}$ (grifo nosso).

O tom é bastante óbvio, e a polêmica do artigo corresponde à preocupação. Observe, é claro, que a preocupação é direcionada à diminuição do que poderia ser chamado de dano à aura mitológica da ciência no reino da crença pública. Igualmente, contudo, um tom fortemente sacerdotal também vem à tona:

É um objetivo deste artigo refutar essas ideias e argumentar que a epistemologia correta é indispensável em qualquer trabalho científico sério e responsável. Pois o que realmente está em jogo não é nada menos que o futuro progresso de nossa civilização. ${ }^{14}$ (itálicos nossos).

O fervor desses defensores da 'epistemologia correta' foi naturalmente fortemente desafiado, não só pelos filósofos, mas pelos cientistas que viram os méritos da lógica rigorosa praticada por muitos filósofos e as percepções fornecidas pela situação da ciência em contextos históricos, sociais, teóricos contextuais e paradigmáticos. A controvérsia durou mais de um ano e, ao final, os autores finalmente responderam aos seus críticos assim:

12 THEOCHARIS, T.; PSIMOPOULOS, M. “Where Science Has Gone Wrong”, Nature 329, October 15, 1987, p. 595.

13 Ibid., p. 595.

14 Ibid., p. 597. 
Uma objeção frequente e apaixonada foi a forma dogmática em que expressamos algumas opiniões. Nós nunca deixamos de ser surpreendidos pela frequência e veemência desta objeção, como alguém pode seriamente dizer com tal paixão qualquer coisa se não tiver total confiança no que diz? A razão pela qual tantas pessoas ficam horrorizadas com o dogmatismo é, obviamente, porque muitos casos no passado causaram muito mal. Mas em todos esses casos o mal foi feito porque aquilo sobre o que as pessoas eram dogmáticas não era verdadeiro. Se o que é dogmático é verdadeiro, este dogmatismo não pode ser prejudicial. ${ }^{15}$

Se tal resposta tivesse ocorrido dentro de círculos literários, poderia muito bem ter sido considerada uma sutil paródia satírica de uma antiga voz. Mas a minha razão para incluir este exemplo quase ridículo, não importa quão prestigiosa a revista em que apareceu, é que revela algo sobre um mythos que é muitas vezes utilizado para tomar o establishment da ciência-tecnologia. De uma consciência pós-moderna, tais convicções dogmáticas sobre uma presumida verdade universal e objetiva justificando uma guerra santa contra a opinião contrária, poderia dificilmente ser percebida como outra coisa que não uma posição arcaica. Ou então é o surgimento de outra forma de fundamentalismo do século XX.

Há também algo de uma ironia pós-moderna aqui visto que o artigo é direcionado para a questão da perda de apoio para a ciência no orçamento britânico, particularmente para a acadêmica britânica. No entanto, os EUA, liderados por um governo igualmente reacionário, não parece ser afetado pela dissolução "causada" pela Nova filosofia da ciência. Em vez disso, a acumulação de dólares em Pesquisa e Desenvolvimento (PD), especialmente ligado a contextos militares e industriais, aumentou drasticamente. Em uma avaliação do apoio da era Reagan à ciência e à tecnologia, a $\mathrm{AAAS}^{16}$ relata um nível de suporte quase duplicado (verifique a tabela na sequência).

\begin{tabular}{|c|c|c|c|}
\hline \multicolumn{4}{|c|}{ Os anos Reagan: Pesquisa e Desenvolvimento (PD) Defesa vs. não Defesa (em bilhões de dólares) } \\
\hline \multicolumn{4}{|c|}{ Investimento em PD relacionados à Defesa (Segurança Nacional e Forças Armadas): } \\
\hline Ano Fiscal 1980 & Ano Fiscal 1988 & Varia & centual \\
\hline Executado (US\$) & Estimado (US\$) & Atual \% & Constante $\%$ \\
\hline
\end{tabular}

15 TEOCHARIS; PSIMOPOULOS, Nature 333, June 2, 1988, p. 309.

16 N. T.: Association for the Advancement of Science.A 'Associação para o Avanço da Ciência' é uma organização americana internacional sem fins-lucrativos com o objetivo de promover cooperação e interação entre os cientistas Foi fundada em 20 de setembro de 1848 e atualmente conta mais de 120 mil membros. 


\begin{tabular}{l|l|l|l|l}
\hline \multicolumn{5}{l}{ Os anos Reagan: Pesquisa e Desenvolvimento (PD) Defesa vs. não Defesa (em bilhões de dólares) } \\
\hline PD Defesa & 15.0 & 40.3 & 169 & 83 \\
\hline Pesquisa Básica & 0.6 & 0.9 & 64 & 11 \\
\hline Pesquisa Aplicada & 1.9 & 2.6 & 38 & -7 \\
\hline Desenvolvimento & 12.5 & 36.7 & 194 & 99 \\
\hline
\end{tabular}

\begin{tabular}{l|l|l|l|l}
\hline Investimento em PD não relacionados à Defesa: \\
\hline & Ano Fiscal 1980 & Ano Fiscal 1988 & \multicolumn{2}{l}{ Variação Percentual } \\
\hline & Executado (US\$) & Estimado (US\$) & Atual \% & Constante \% \\
\hline PD Não-Defesa & 16.7 & 18.8 & 13 & -24 \\
\hline Pesquisa Básica & 4.2 & 8.6 & 107 & 40 \\
\hline Pesquisa Aplicada & 5.0 & 6.5 & 29 & -13 \\
\hline Desenvolvimento & 7.5 & 3.7 & 50 & -66 \\
\hline
\end{tabular}

Os anos Reagan: Investimento em Pesquisa Básica pelas Agências Federais (em milhões de dólares)

\begin{tabular}{l|l|l|l|l}
\hline & Ano Fiscal 1980 & Ano Fiscal 1988 & \multicolumn{2}{|l}{ Variação Percentual } \\
\hline Agência $^{1}$ & Executado (US\$) & Estimado (US\$) & Atual \% & Constante \% \\
\hline NIH & 1.644 & 3.855 & 134 & 59 \\
\hline NSF & 830 & 1.438 & 73 & 17 \\
\hline Defesa & 552 & 901 & 63 & 11 \\
\hline Energia & 523 & 1.172 & 124 & 52 \\
\hline NASA & 559 & 1.074 & 92 & 30 \\
\hline Agricultura & 280 & 471 & 68 & 14 \\
\hline Outros & 328 & 613 & 87 & 26 \\
\hline Total & 4.716 & 9.526 & 102 & 37 \\
\hline
\end{tabular}

Fonte: AAAS e “OMB Data for Special Analysis J, FY 1989 Budget”.

1 NIH: National Institutes of Health (Instituto Nacional de Saúde); NSF: National Science Foundation (Fundação Nacional de Ciência); NASA: National Aeronautics and Space Administration (Administração Nacional da Aeronáutica e Espaço).

Deve-se concluir com isto que o aumento global de 85 por cento para a Pesquisa e Desenvolvimento da ciência nos EUA ocorreu porque nossos secretários departamentais e seus funcionários não conseguiram ler os novos filósofos da ciência, enquanto o gabinete britânico e seus funcionários o fizeram e então seguiram uma conclusão presumivelmente implícita na leitura de que o financiamento da ciência deveria ser cortado? Todo o escrito na Nature evitou o óbvio sobre a desilusão pública relacionada com os efeitos negativos de uma 
política de grande parte da ciência. A poluição radioativa do Mar da Irlanda, as chuvas ácidas, a poluição atmosférica, etc., são questões bastante públicas tanto na Grã-Bretanha quanto aqui. E enquanto os puristas podem argumentar que esta é meramente a política errada para a aplicação da ciência, o público vê frequentemente a ciência-tecnologia como uma única e grande unidade. ${ }^{17}$

Embora eu suspeite que o declínio do apoio britânico à ciência acadêmica se relacione com a poda severa de todo o fenômeno de crescimento universitário pós-1960 e um retorno ao pré-1960 em que existia um quase monopólio Oxbridge (Oxford e Cambridge) do ensino superior de elite do que a diminuição da fé na ciência, o que estou usando deste incidente é o seu índice sobre certa falta de maturidade dentro de grandes segmentos da comunidade científica em relação à crítica. Embora a ciência institucional possa legitimamente se orgulhar de seus padrões internos de crítica (dirigida à crítica da experiência, da coleta de dados, do design da pesquisa, do raciocínio matemático e dedutivo, etc.), nem sempre é tão madura em relação à crítica autorreflexiva.

Em 1977, Langdon Winner publicou seu livro Autonomous Technology: Technics-out-of-Control as a Theme in Political Thought. Embora o título por si só indica que ele está se dirigindo a um modo de interpretação da tecnologia, leitores acríticos e revisores frequentemente consideravam o resultado como sendo antitecnológico. No tempo em que escreveu The Whale and the Reactor, que apareceu em 1986, ele aprendeu a seguinte lição:

Se fosse uma crítica literária, todos entenderiam imediatamente que o propósito subjacente é positivo. Um crítico da literatura examina um trabalho, analisando suas características, avaliando suas qualidades, buscando uma apreciação mais profunda que possa ser útil para outros leitores do mesmo texto. Da mesma forma, os críticos da música, do teatro e das artes têm um papel valioso e bem estabelecido, servindo como uma ponte útil entre artistas e audiências. A crítica da tecnologia, no entanto, ainda não tem a mesma satisfação. Os escritores que se aventuram além das concepções mais pedestres e aborrecidas sobre as ferramentas e usos para investigar formas pelas quais as formas técnicas estão implicadas nos padrões e problemas básicos de nossa cultura são frequentemente saudados com a acusação de serem

17 RICHARDS, Steward. Philosophy and Sociology of Science (New York: Shocken Books, 1984), p. 157. Aqui se encontram outras razões prováveis pelas quais o público esta perdendo o entusiasmo pelo financiamento ilimitado e acrítico a projetos científicos: $\mathrm{O}$ vazamento da usina britânica em Windscale foi descrita como incontornável, e o Mar da Irlanda é agora tido por alguns como sendo o mais radioativo do mundo. Alguns resíduos permanecerão letais por dezenas de milhares de anos e a tecnologia para a sua eliminação ainda não foi desenvolvida. 
meramente "antitecnologia" ou por "culpar a tecnologia". Todos os que passaram recentemente à frente como críticos neste reino foram tomados pelo mesmo pincel idiota, uma expressão do desejo de parar um diálogo muito necessário em vez de ampliá-lo. ${ }^{18}$

$\mathrm{Na}$ "controvérsia da Natureza", pode-se ver que as mesmas tendências não autorreflexivas ocorrem dentro de alguns círculos científicos. Deve-se ter cuidado aqui para qualificar qualquer reivindicação muito ampla, uma vez que, mesmo nessa controvérsia, cientistas e filósofos reagiram criticamente ao artigo de Theocharis-Psimopoulos.

Contudo, ao contrário das artes e das letras, o papel da crítica, particularmente para além dos limites mais estreitos e internos da autorregulação, ainda não está totalmente assimilado à ciência e à tecnologia como instituição. A história e a filosofia da ciência devem ser consideradas análogas à crítica artística e literária e ao historiador e ao filósofo como profissionais que proporcionam uma visão e, muitas vezes, uma apreciação mais profunda, bem como mais corretivas e criticamente negativas. Esse foi claramente o objetivo dos quatro novos filósofos da ciência retratados na Nature em uma exposição fotográfica intitulada "Betrayers of truth? Left to right: Karl Popper, Imre Lakatos, Thomas Kuhn and Paul Feyerabend". ${ }^{19}$

Antes de deixar esta controvérsia tomada, um ponto mais sugestivo é revelado no incidente. O próprio apelo à defesa (indefinida) da "verdade" e da "objetividade", no contexto da preservação de um mito que efetivamente apoiaria de forma acrítica a pesquisa científica, passou a ser examinado pela sociologia da ciência. O pedido de isenção da crítica pode ser ele próprio ideológico:

Talvez não ficássemos muito surpresos se os membros da sociedade que mais desejassem subscrever a noção de neutralidade científica fossem os próprios cientistas. Muitos cientistas praticantes, inconscientes ou desconhecedores como são da filosofia da ciência, se apegam a uma concepção idealizada de sua profissão e propagam uma visão da "verdade científica" que implica numa completa certeza, objetividade e desapego. Tal visão pode ser mantida com o pleno conhecimento de que muitos tipos de ciência só podem ser praticados em virtude do apoio financeiro fornecido por governos ou empresas industriais com objetivos que são frequentemente obscuros e quase sempre dirigidos

18 WINNER, 1986, p. xi.

19 “Traidores da verdade? Da esquerda para direita: Karl Popper, Imre Lakatos, Thomas Kuhn and Paul Feyerabend". 
por interesses políticos ou econômicos. Incompatíveis como parecem essas duas posições, ainda é verdade que o prestígio e a autoridade da ciência são tais que são amplamente aceitos, mais ou menos sem pensar, pelo público em geral. Até certo ponto pelo menos, a ciência usurpou o território anteriormente mantido pela religião. ${ }^{20}$

Se a relação ciência/filosofia-da-ciência e as tradições de debate sobre a interpretação da ciência e da tecnologia são bastante recentes, um debate muito mais antigo que remonta aos primórdios da ciência moderna, a relação e debate religião/ciência deve pelo menos ser mencionado. E apesar de não abordar extensivamente esta questão, pode-se notar que muitas vezes mythos contrários estão também aqui em disputa. Expressões em livros escolares de, pelo menos, uma variante dominante do mito científico relaciona-se com sua própria versão de desmitificação. De fato, a já examinada teoria das revoluções progressistas (copernicana, darwiniana, etc.) é em si mesma um exemplo desse mito. O mito da ciência procura afastar-se do mito religioso que a ciência chama de superstição, que deve ser substituída pelas metáforas racionais e geralmente redutoras de um tipo mecânico ou eletrônico. Mas ao fazê-lo, a ciência também desvia a possibilidade de certo tipo de avaliação preservada no mito religioso. Assim, continua uma contestação entre esses dois tipos de mitos.

Muito do interesse e da importância tem surgido a partir deste debate, particularmente no que diz respeito às metáforas-míticas chaves sobre o universo, a ideia do ser humano, etc. Embora o resultado varie dos extremos atuais de uma reação fundamentalista à própria ciência em si sintomatizada nos atuais debates "criacionistas" sobre possíveis acomodações entre a ciência e a religião em contextos mais liberais, o impulso geral tem sido claramente para uma crescente secularização nos países onde a ciência-tecnologia enquanto instituição aprofunda as suas raízes. Isso faz parte da não neutralidade institucional da cultura tecnológica.

Uma terceira, e para mim, a crítica contemporânea mais interessante surge a partir de um revisionismo filosófico e histórico acerca de como a ciência opera e deve ser entendida. Um efeito colateral interessante deste debate contrasta o entendimento do processo histórico de alguns filósofos e historiadores com o de alguns cientistas que às vezes desejam igualmente controlar tal história e mantê-la dentro da matriz das narrativas sobre "grandes homens, grandes eventos."

20 RICHARDS, 1984, p. 148. 
Embora nem todos os cientistas interessados na história da ciência possam ser acusados de ingenuidade histórica, a forma dominante de histórias originadas na ciência (como evidenciado pelas resenhas de livros na Science) é a de narrativas biográficas ou autobiográficas. Em si, tal abordagem pode não parecer prejudicial. Mas, na medida em que serve para perpetuar um dos mitos-padrão sobre a ciência, tais narrativas precisam, pelo menos, de um suplemento mais crítico; no máximo, uma séria desmitificação.

Esse mito é o do herói-cientista, trabalhando sozinho ou, pelo menos, individualisticamente fazendo alguma grande descoberta, imerso em algum cenário dramático e romântico. A Grande Ciência Contemporânea não funciona dessa maneira, agora ou no passado, exceto em alguns casos, de acordo com a maioria dos historiadores sociais. Mas a perpetuação dessa estrutura mística desempenha um papel:

Thomas S. Kuhn, por exemplo, destacou que os jovens devem ser recrutados para a ciência através de promessas implícitas de aventuras heroicas nas fronteiras do conhecimento; eles não seriam atraídos ao saber que $99 \%$ deles passariam suas vidas apenas resolvendo os enigmas da "ciência normal" que constituem a vasta maioria das pesquisas hoje. Nem podemos acrescentar que eles seriam atraídos pela perspectiva de um "bom trabalho na linha de montagem" na produção do conhecimento científico que é a forma social dentro da qual a ciência normal é praticada. ${ }^{21}$

No entanto, mesmo essa "visão padrão mitológica" pode permitir que as pessoas cheguem a algo bem distante do que previa a intencionalidade dessa visão. Ainda usando esta forma narrativa, A Dupla Hélice de James Watson revelou mais do que a maioria das pessoas nas ciências desejavam, tal como as resenhas indicavam. Em sua abordagem de "grandes homens, grandes eventos", o relato de sobre a corrida por um prêmio Nobel de Watson, Crick e Wilkins por meio da quebra de um código de DNA, revelou uma faceta humana embaraçosa e avessa para o processo. Não só os diretores eram frequentemente competitivos, invejosos, muitas vezes chegando às fronteiras da fraude e relutantes em dar crédito, mas A Dupla Hélice mostrou a forma aberta e direta do chauvinismo masculino que se tornou o alvo mais apontado pelos críticos da ciência contemporânea, as críticas feministas.

21 HARDING, 1986, p. 69. 
A atitude condescendente de Watson em relação a "Rosie" se mostra. Foi a partir das imagens cristalográficas de Rosalind Franklin (novamente imagem-tecnologia) que Watson obteve a sua visão, mas ele também revela repetidamente seu chauvinismo e condescendência com nossas mulheres em ação. Ruth Bleier apontou severamente esta característica:

Não poderia haver uma demonstração mais fina da centralidade das metáforas de gênero na ciência [que continuam como] [...] a arrogância misógina [que] continuou a prosperar entre os prêmios Nobel da ciência. James Watson foi o menino de ouro de Harvard quando [...] ele ganhou o Prêmio Nobel em 1962 por descrever a estrutura helicoidal dupla do DNA [...] depois de ilícita e secretamente ver as imagens cristalográficas inéditas do DNA de Rosalind Franklin. ${ }^{22}$

O mesmo "menino de ouro", já em 1985, queixando-se do movimento para regular a engenharia genética, foi citando como tendo dito:

Poder-se-ia esperar que os republicanos fossem mais sensatos quanto aos regulamentos, mas eram tão tolos quanto os outros [...] A razão é que a Casa Branca recebe seus conselhos de pessoas que sabem alguma coisa sobre física ou química. A pessoa responsável pela biologia ou é uma mulher ou alguém sem importância. Eles tiveram que colocar uma mulher em algum lugar $[. . .]^{23}$

Se houvesse uma mudança para os historiadores sociais, um quadro inicial diferente emergiria. Derek de Solla Price, nosso anterior intérprete de Galileu, também fazia parte da revolução revisionista do início dos anos 60 com sua agora bem conhecida Little Science, Big Science (1963). Lá ele começou a mostrar algumas das características sociais e históricas do que é agora comumente conhecido como Grande Ciência. Ele mostrou que, a partir do século XIX, a instituição da ciência começou a crescer exponencialmente e, com ela, a literatura científica. Mas também começou a ser verdadeiramente uma ciência corporativa, ilustrada de acordo com a forma indiciada pela forma como as autorias das publicações o fizessem. Hoje é raro que qualquer artigo científico tenha um único autor (além da opinião ou sumários do estado da arte escritos pelas lideranças no campo, mesmo nosso comentário na Nature citado anteriormente foi

22 BLEIER, Ruth (ed.). Feminist Approaches to Science. Madison: University of Wisconsin Press, 1968, p.6-7.

23 Ibid., p. 7. 
em coautoria!). E, apesar do esboço igualmente importante do que Price chamou de Colégios Invisíveis do pequeno grupo dos líderes da elite e editores em qualquer campo, as publicações em coautorias foram muitas vezes o resultado de um exército de trabalhadores de laboratório com controle apenas escasso e distante do "P.I." (investigador principal). Esta estrutura corporativa de publicação e pesquisa está muito longe das histórias sobre o Grande Homem ainda favorecidas por muitos escritores individuais. Evidência da distância demasiado frequente da elite P.I. do trabalho de laboratório e de coleta de dados da "fábrica” é o fenômeno crescente de manipulação de dados e outras formas de fraude corporativa, que agora desempenham um papel constante na discussão de muitas das principais revistas científicas.

A Dupla Hélice de Watson, no entanto, permanece na tradição do Grande Homem, embora fosse autobiográfica o suficiente para revelar as próprias verrugas, bem como o presumido heroísmo intelectual.

A reação da comunidade científica a essa abordagem roupa-suja era muitas vezes fortemente negativa. Ela demonstra muitos pontos fracos humanos e fraquezas sobre o processo que, miticamente, muitos sentem ser necessário para que possa ser retratado mais romanticamente. Essa perspectiva histórica ingênua fez mais para humanizar a operação da ciência do que muitas outras obras que ainda estão sendo publicadas. Mas também telegrafou um senso de contingência elevado e apropriado para perceber a ciência como apenas mais um empreendimento humano dentro do qual os humanos falíveis trabalham.

Nem se deve negligenciar o mais revolucionário dos revisionistas, o próprio Thomas S. Kuhn. Embora Kuhn provavelmente tenha feito mais para desmitificar a interpretação dos filósofos da ciência do que ele fez para a história da ciência em si, ele claramente reformulou a forma como as descobertas frequentemente ocorreram. Mesmo que sua própria versão dessa história permaneça parcialmente imersa em uma versão um tanto idealizada da primazia da teoria, ele foi capaz de transferir a atenção para elementos importantes da práxis perceptiva dentro da ciência. Esta mudança na história da ciência é agora bem conhecida, e eu não vou levá-la ainda mais adiante aqui. Mas ele desempenhou parte do papel da desmitificação, que eu estou apoiando como sendo necessário.

Eu também segui duas outras vertentes desta história revisionista neste livro. Uma delas refere-se ao revisionismo da visão-padrão de que a tecnologia moderna é "aplicada" à ciência ou derivada da ciência. O revisionismo mais radical dessa visão era heideggeriano; ele inverte a visão usual e vê a ciência como 
o resultado necessário de um braço tecnológico da ciência. De uma forma mais moderada, uma visão similar aparece na versão de White da revolução tecnológica medieval, revolução que prepara o cenário que inclui a poderosa metáfora para a ciência moderna. Ainda num nível mais moderado, porém acumulativo, Rachel Lauden aponta de modo similar:

Recentes ataques ao conceito de tecnologia como ciência aplicada se utilizam de duas estratégias, uma empírica e outra analítica. Na frente empírica, historiador após historiador tem narrado episódios sobre o desenvolvimento da tecnologia em que os avanços principais devem pouco ou nada à ciência. Quer se trate do vapor, energia hidráulica, máquinas-ferramentas, relojoaria ou metalurgia, a conclusão é a mesma. A tecnologia desenvolvida sem o auxílio da teoria científica, uma posição resumida pelo slogan, "a ciência deve mais à máquina a vapor do que a máquina a vapor deve à ciência"."

Esse revisionismo era contextualmente apropriado para meu foco na tecnologia. Mas, indiretamente, faz parte da desmitificação da ciência como sendo a mais importante atividade de coleta de conhecimento cultural humano, e as afirmações aqui foram simplesmente muito fortes e precisam ser moderadas para trazer a ciência de volta à sua escala humana.

A segunda vertente revisionista, mais uma vez não exclusiva dessa perspectiva, mas que surge mais diretamente da visão da ciência, tanto corporificada na tecnologia (instrumentação) como contextualmente localizada, está e sempre esteve profundamente enraizada em suas conexões concretas com as tecnologias em seus papéis mais amplos. Estes incluem, minimamente, a fabricação de ferramentas e o desenvolvimento de instrumentos (de Solla Price) e, mais amplamente, as necessidades por engenharia das forças armadas e da indústria. Exceto pelos criadores de mitos do século XIX e os idealizadores teóricos positivistas do início do século XX, não vejo necessidade de conceber a ciência de outra maneira. No mínimo, esta visão não purista da ciência como uma instituição social ajuda a mantê-la no equilíbrio como uma - não como $a$ - atividade humana de conhecimento privilegiada.

O revisionismo que veria a ciência desde o início mais ligada à tecnologia pode ser debatido em relação a momentos históricos; mas no século XX, há

24 LAUDAN, 1984, p. 10. 
pouca dúvida de que alguma forma de instituição ciência-tecnologia é o modo dominante. Mesmo uma visão mais conservadora sustentaria que:

A convergência da ciência com a tecnologia em grande escala começou, então, com o aparecimento do laboratório de pesquisa e desenvolvimento industrial no final do século XIX, uma tendência que começou na Alemanha e seguiu rapidamente nos Estados Unidos e depois na Grã-Bretanha [...] Simbiose industrial depois disso se tornou autoperpetuada porque era cada vez mais perigoso para governos e corporações comerciais ser deixado para trás na corrida competitiva por novos processos tecnológicos e produtos [...] Os resultados no século XX deste quase-sindicato da ciência e da tecnologia são muito numerosos e muito conhecidos para serem repetidos. ${ }^{25}$

Estas formas entrelaçadas de revisionismo, naturalmente, reverberam positivamente com as críticas fenomenológicas e hermenêuticas originárias das tradições filosóficas euro-americanas. Aqueles que colocam a ciência como uma instituição dentro de um campo e veem-na como uma forma, mesmo que uma forma única, da práxis humana, são aqueles que guiaram a investigação até este ponto.

Uma das entradas mais recentes no campo das críticas desmitificadoras, no entanto, tem sido o aparecimento da crítica feminista. Esta linha de crítica é particularmente interessante. Não só é distintamente pós-moderna, como também isolou um tema que gira em torno de perspectivas de gênero, que lhe deram uma perspectiva muito focalizada e, ainda assim, alcançando culturas e histórias. À desmitificação deve-se acrescentar o projeto de "desmasculinização" ou, positivamente, a pluralização de gênero.

Deve ser dada especial atenção a este modo de crítica porque o feminismo, em um aspecto, atravessa todas as combinações culturais previamente notadas. Seja qual for a variedade de estratégias culturais para os gêneros e se as feministas estão certas, a estratégia dominante tem sido, de longe, favorecer os homens, pois essa nova perspectiva deve ser engendrada investigando as perspectivas do papel do sexo nos níveis micro e macro. Dentro da ciência, em pequena escala e em áreas específicas, as críticas feministas e as perspectivas já conseguiram revolucionar os subcampos. Uma das mais sugestivas foi a área da primatologia em suas dimensões comportamentais. No entanto, como observa Watson, 
há uma porcentagem maior de mulheres nas ciências biológicas do que nas ciências físicas e químicas (que, corretamente ele aponta, tiveram a pista interna em arenas políticas) e dentro de algumas das ciências biológicas, as mulheres cientistas, novamente apontando para o campo da primatologia, vieram à tona. Jane Goodall e Dian Fossey capturaram a imaginação popular com seus respectivos estudos de chimpanzés e gorilas.

O que ainda não pode ser plenamente apreciado é o modo como a perspectiva feminista transformou a primatologia em relação aos papéis sexuais entre os primatas. Um exemplo vem do trabalho de Sarah Blaffer Hrdy sobre lêmures. Atacando a longa tradição darwiniana, que interpretava a fêmea da espécie na seleção sexual como passiva, tímida e recatada (obviamente ligada aos valores vitorianos para a fêmea), Hrdy estabeleceu o que poderia ser chamado de contra-versão da seletividade sexual entre os lêmures imitando mais de perto a libertada, pós-moderna fêmea do presente.

Hrdy argumenta que "a dicotomia inicial entre machos ativamente cortejadores e promíscuos e fêmeas não andróginas passivamente escolhidas remonta aos tempos vitorianos. 'Os machos são quase sempre os brincalhões', escreveu Darwin." ${ }^{26}$ Em seus próprios estudos e observações, Hrdy diz: "Eu argumentaria que um componente poliédrico está no cerne dos sistemas de criação da maioria dos primatas que habitam as tropas: as fêmeas se acasalam com muitos machos, cada um dos quais pode contribuir um pouco para a sobrevivência da prole." ${ }^{27}$

Os estudos de Hrdy não são apenas feministas; eles são parte do anteriormente mencionado encurtamento da distância entre nós e nossos vizinhos animais, embora aqui a questão orbite em torno de questões de gênero. Ela juntamente a outras, ao tomar uma perspectiva diferente, claramente desmasculinizou o campo da primatologia. A fêmea recatada desapareceu definitivamente em uma diversidade de espécies desde as drosófilas até os felinos, da perda brilhante aos babuínos das savanas, as fêmeas de todas estas espécies demonstram envolver-se em atividades de cortejo e apresentam um comportamento nada tímido.

Um alerta de precaução deve ser inserido sobre as histórias de tais mudanças de "paradigma". Donna Haraway, uma editora de biologia transformada em historiadora da ciência, reconhece criticamente a necessidade de uma cuidadosa hermenêutica de todas essas mudanças. Reconhecendo que as feministas que

\footnotetext{
26 HRDY, Sarah Blaffer. "Empathy, Polyandry, and Myth of the Coy Female," Feminist Approaches to Science, New York: Pergamon Press, 1986, p. 118.

27 Ibid. p. 125.
} 
fizeram um grande impacto e que nas áreas de seleção sexual de primatologia são agora provavelmente as pesquisadoras dominantes, também devem enfrentar as ambiguidades de ler o humano através do animal (texto). Haraway mostra a atitude crítica mais sofisticada da historiadora em relação à ciência, que afirmei que muitas vezes é escasso demais dentro da própria comunidade científica.

Haraway sublinha o caráter literário e simbólico da própria ciência em suas últimas tentativas de chegar à tênue linha entre o animal e o humano nos primatas e do novo papel que as mulheres estabeleceram na primatologia. Em seu "Primatology in Politics by Other Means", Haraway destaca os avanços realizados:

Até muito recentemente na história da primatologia, praticamente nenhuma mulher tinha o estatuto de cientista neste campo [...] [Mas agora] essas mulheres fizeram uma grande diferença nas construções científicas na primatologia no que diz respeito a que significa ser um animal fêmea, E assim do que significa ser um homem ou uma mulher em sociedades para as quais a construção social do animal é parte da construção social do humano. ${ }^{28}$

No entanto, é precisamente por causa deste status limítrofe que os primatas são difíceis de "ler". Haraway destaca que "os ocidentais têm acesso a macacos e primatas apenas sob circunstâncias simbólicas e sociais específicas [...] É muito difícil estabilizar a verdade sobre macacos e primatas". ${ }^{29}$

Como uma historiadora da ciência pós-kuhniana, Haraway acertadamente nota que mesmo o que é chamado de "fato" é algo que depende de um campo ou de um contexto; ainda mais, é dependente de campo no sentido de ser "carregado de história":

Valores parece ser uma palavra anêmica para transmitir as múltiplas vertentes de significado tecidas nos corpos de macacos e primatas. Por isso, prefiro dizer que a vida e as ciências sociais em geral e a primatologia em particular são carregadas de história; Essas ciências são compostas por práticas históricas complexas e historicamente específicas. Os fatos são carregados de teoria; as teorias são carregadas de valor; os valores são carregados de história. ${ }^{30}$

28 HARAWAY, 1968, p. 78.

29 Ibid., p. 78.

30 Ibid., p. 79. 
Esta é a "nova" ou pós-kuhniana filosofia da ciência-padrão. (Ela é também boa fenomenologia).

Com a cautela hermenêutica agora aguçada, podemos retornar ao exemplo de Hrdy. Podemos ver que, sem de forma alguma rebaixar suas observações de campo sobre o comportamento dos lêmures, com seus "fatos", Hrdy fez mais: ela contou uma nova história, desde um novo contexto de interpretação. Mais uma vez, Haraway:

Raramente as competições feministas para o trabalho do significado científico substituirão um paradigma com outro, levantando e estabelecendo com êxito contas e teorias completamente alternativas. Em vez disso, como uma forma de prática narrativa ou de contar histórias, a prática feminista em primatologia tem trabalhado mais alterando um "campo" de histórias ou possíveis relatos explicativos [...] Toda história em um "campo" altera o status de outros. O conjunto inter-relacionado de histórias é o que eu chamo de campo narrativo. ${ }^{31}$

Isto é o que Hrdy fez com os lêmures, mas neste caso é também o que pode ser chamado de "desmasculinização" positiva da ciência. Eu não tenho a intenção de lançar um tom pejorativo ou negativo sobre o masculino exceto em sua tendência para o chauvinismo (tal como no exemplo acima de Watson), mas indicar que a alteração do campo narrativo possibilita à multiplicidade de aspectos de gênero ser reavaliada e reposicionada em um quadro mais completo. A desmasculinização, idealmente, é o primeiro passo rumo à pluralização de gêenero, uma condição pós-moderna mais apropriada.

No entanto, a história anterior da ciência pode ser vista como a progressão da masculinização. Sanda Harding, em uma das mais abrangentes e reveladoras das críticas feministas à ciência, faz a seguinte afirmação:

Quando a teoria de Copérnico substituiu o universo centrado na terra por um universo centrado no sol, também substituiu um universo centrado na mulher por outro centrado no homem. Para o Renascimento e o pensamento anterior dentro de uma concepção orgânica da natureza, o sol estava associado à masculinidade e a terra com dois aspectos opostos da feminilidade. A natureza, e especialmente a terra, foi identificada, por um lado, com uma mãe nutriente "uma fêmea amável e benéfica que supriu as necessidades da humanidade num universo ordenado e planejado" e, por outro lado, a "selvagem e incontrolável

31 Ibid., 79. 
[fêmea] natureza que poderia se voltar à violência, tempestades, secas e caos geral." Na nova teoria de Copérnico, a terra feminina, que fora a criação especial de Deus para o sustento do homem, tornou-se apenas um minúsculo planeta movido externamente que circundava uma órbita insignificante em torno do sol masculino ${ }^{32}$

Eu não sei se, tal como algumas feministas afirmam, os valores do cuidado, da nutrição, da empatia são acidentalmente ou intrinsecamente mais femininos do que os valores de proteção, dominação ou controle, que às vezes são tidos como valores masculinos. Mas é claro que a ciência dominada por este último claramente precisa de uma dose pesada do primeiro, se um equilíbrio deve ser atingido e ainda mais, se a terra deve ser conservada. Por esta razão, uma das tarefas intrínsecas para o presente deve ser a desmasculinização da ciência dentro e ao lado da tarefa de desmitificar sua falsa mística.

Sabia Galileu, quando confirmou a teoria copernicana através de sua nova revelação artificial, que ele também estava descentrando a terra como nossa fonte de nutrição? Mas, então, Galileu deve servir aqui como nosso "primata", na medida em que é através de Galileu ou dos múltiplos Galileus que já vimos que a história da ciência é contada e recontada. A desmitificação e a desmasculinização associada fazem parte da nova narrativa necessária para alterar o campo atual das histórias.

Se a ciência é de fato a ferramenta conceitual da civilização tecnológica, então a sua reformulação em uma ferramenta que aumenta o cuidado e a nutrição da terra como nosso habitat herdado pertence tanto ao reposicionamento da ciência dentro da sociedade como à tarefa de desenvolver uma ética de conservação mundial. Ambos estão inter-relacionados.

\section{Galileu na cozinha}

Se a necessidade é por uma sensibilidade mundial para a conservação da terra, e um meio de trabalhar nesse sentido implica desmitificar e desmasculinizar a ciência existente, e sobre a tecnologia? A partir do que precedeu, ficará claro que não discuti nenhum dos programas, por vezes populares, relacionados 
a tecnologias alternativas, seja "apropriadas"33, "pequeno é belo"34, ou mesmo descentralizado sobre sistemas ou subsistemas centralizados. Embora certamente não me oponha a nenhuma dessas diretrizes que corrijam os abusos e as grandes oscilações negativas encontradas em muitas trajetórias atuais, sou cético em relação a tais panaceias, tanto por causa dos equívocos em torno das questões de "controle" quanto porque nenhum parece plausível dentro dos vetores atuais.

Tais vetores incluem o orçamento de defesa recentemente aprovado para os Estados Unidos, com o valor de US\$ 300 bilhões (1989). Esta magnitude indica claramente quais as tecnologias que recebem o maior favorecimento. Ressuscitar a estrutura do campo das histórias sobre tecnologias exige uma mudança muito mais ampla e profunda do que é possível aqui, mas é por isso que os filósofos, historiadores e humanistas devem continuar a lutar. Tal mudança também deve ocorrer dentro da comunidade dominante da própria ciência tecnológica.

Se Galileu for o nosso "primata" por meio do qual "lemos" a ciência contemporânea, pode haver um segundo Galileu através do qual podemos "ler" uma ciência pós-moderna?

Galileu II se encontra numa cozinha depois de passar o dia no laboratório de física. Como um marido liberal, ele compartilha na preparação do jantar com Eva, sua esposa, e Adão, seu filho, que vai chegar em breve do trabalho e da escola. Ele gosta de sua tarefa culinária não só porque ele gosta do processador de alimentos, facas de aço-carbono, utensílios de cozinha com fundo de cobre, mas porque enquanto ele trabalha nos menus variados, porém saudáveis, ele tem a chance de sonhar acordado. Assim, esta noite, enquanto prepara uma primeira rodada de poisson cru, um prato franco-taitiano de peixe, que será acompanhado por vegetais fritos ao estilo oriental, ele se entrega a alguns pensamentos sobre a realização de desejos, que ele reconhece vestirem as fantasias da utopia.

Ultimamente, ele tem pensado em uma mudança de carreira na meia-idade, típica da vida pós-moderna, já que ele tem se cansado com o estresse constante das aplicações de subsídios e com as prioridades frequentemente demasiado

33 “Tecnologias apropriadas" é um movimento ideológico abrangendo escolha tecnológica e aplicação em pequena escala, descentralizada, intensiva em mão-de-obra, eficiente em temos energéticos, ecologicamente correta e localmente autônoma. Foi originalmente articulado pelo economista E. F. Schumacher em seu trabalho "Small is Beautifull”. O termo é usualmente utilizado para enfatizar as tecnologias centradas nas pessoas. (N. do T.)

34 "Pequeno é belo" é uma expressão popularizada a partir do livro "Small is Beautiful: A Study of Economics As if People Mattered" (1973) do economista britânico E. F. Schumacher. A frase "pequeno é belo" é usada normalmente para indicar que pequenas, "tecnologias apropriadas" que se acredita empoderam as pessoas mais, em contraste a frases tais como "maior é melhor”.(N. do T.) 
determinadas das agências de subsídios. Ele tem sido um crítico da $\mathrm{SDI}^{35}$, da Estação Espacial, e até mesmo tem dúvidas sobre a sabedoria de um Grande Colisor, particularmente à luz dos bilhões de dólares envolvidos. Além disso, ele sabe que até mesmo os amadores poderiam facilmente sabotar o sensor planejado e o sistema de canhão a laser que vem se sonhando para a SDI, os veículos não tripulados poderiam fazer observações científicas mais reais do que a Estação Espacial e o provável avanço tecnológico poderia tornar o Colisor obsoleto antes mesmo de ele ser terminado.

Ele se pergunta o que seria do mundo da ciência se suas atuais hierarquias, tão bem enraizadas na academia, na política e no complexo militar-industrial, fossem mudadas. E se as ciências físicas e da terra fossem orientadas diretamente para programas de conservação que respondessem a preocupações públicas demonstradas pela limpeza dos oceanos e da atmosfera? E se as disciplinas ecológicas tivessem precedência sobre a atual raiva da biotecnologia? E se as ciências sociais e mesmo as humanidades e as artes fossem financiadas em qualquer coisa como a escala de sua ciência?

Levado por si mesmo, ele começa a fantasiar um novo tipo de avaliação de tecnologia que não apenas inclui os estudos de impacto ambiental minimalistas atuais, mas também exige uma declaração de impacto estético e comunitário. Está bem ciente de que em sua universidade a administração dominante sempre pergunta se seus programas de história e humanidades têm elementos curriculares relacionados às ciências e se o planejado Instituto de Gerenciamento de Resíduos precisava ter uma conexão semelhante com a comunidade de arte e o mundo, a dimensão "artística" da eliminação de resíduos? E se todo o desenvolvimento tecnológico dependesse e fosse financiado em relação ao desenvolvimento de elementos ambientais, sociais e de justiça distributiva?

Ele começara a pensar dessa maneira notadamente herética e claramente desejável desde que começou a se perguntar como seria o mundo para o jovem Adão. Às vezes, ele invejava o menino, que podia, com igual entusiasmo, apreciar os lagartos tomando sol na parede da rocha junto à casa, o canal MTV alto e barulhento e seu computador de brinquedo.

Antes que ele possa ser levado demais em seus pensamentos e deixe queimar o stir fry, Eva chega e relata-lhe que alguns de seus colegas no Northwest

35 SDI - Strategic Defense Initiative (Iniciativa Estratégica de Defesa): A Iniciativa Estratégica de Defesa, também conhecida como Star Wars, é o programa militar do governo dos Estados Unidos proposto pelo Presidente Ronald Reagan, para construir um sistema defensivo de armas espaciais capazes de impedir um ataque nuclear contra o território dos Estados Unidos. 
tinham finalizado um estudo com rapazes e na amostra da pesquisa descobriu-se que o único e mais importante valor que eles classificaram como sendo o maior foi a paternidade. Esta foi a primeira vez na história em pesquisas semelhantes em que a paternidade sequer apareceu na lista! Eva, talvez para provocá-lo, às vezes argumentava que, além de uma exigência da cultura não ocidental para o currículo central, deveria haver um conjunto necessário de cursos, enfocando as formas variantes de criação humana e animal, para equilibrar a já requerida "alfabetização tecnológica".

Este argumento dispersou Galileu II novamente quando voltou à cozinha para preparar uma sobremesa de queijo e frutas. Qual seria a estrutura de financiamento para a ciência e tecnologia se os seus ancestrais homônimos, os príncipes e comerciantes daquele tempo fossem substituídos por agências de financiamento voltadas para as necessidades sociais, economicamente focadas apenas na distribuição da riqueza, voltadas para questões de cuidado humano e conservação do planeta Terra? Ele não podia sequer imaginar tal possibilidade, embora fantasiar que tipos de tecnologias seriam inventadas em um mundo como esse poderia ser um bom devaneio para a noite de amanhã.

\section{Concluindo: Posfácio sobre a Ciência Tecnológica}

Galileu II é uma fantasia. Nem as mudanças sonhadas e desejadas vão acontecer através de conversas individuais ou no âmbito familiar. Os problemas com as tecnologias modernas são muito profundos e muito entrincheirados com hábitos seculares para serem alterados de uma maneira fácil, embora suas distorções já começaram a aparecer.

Em contraste com o espírito pós-moderno, a tecnologia e a ciência tecnológica permanecem ligadas a grandes estruturas hierárquicas e, na Grande Ciência, há até o que foi analisado como sendo algo semelhante ao sistema de uma fábrica:

Os gestores-distribuidores da ciência são apenas uma pequena minoria de trabalhadores científicos. Uma fonte estima que "cerca de 200 a 300 dos principais tomadores de decisão, principalmente cientistas, constituem a elite interna de uma força de trabalho científica total de cerca de dois milhões". Executando quase todo o trabalho realmente necessário para produzir crença científica estão os aproximadamente 
1.999.700 técnicos em laboratórios e trabalhadores que fabricam o equipamento e materiais para investigação científica. ${ }^{36}$

O que é triste, até mesmo trágico, sobre este estado de coisas é que o gênio da ciência moderna é sua incorporação tecnológica. Foi através da incorporação, na captação e desenvolvimento da instrumentação para a experiência, que toda a visão do mundo mudou. Ela nos revelou macro e micromundos nem sequer sonhados pelos imaginadores de histórias e culturas pré-modernas da ciência. Tampouco as cosmologias do globo ocular poderiam começar a elaborar ou extrapolar as maravilhas do realismo instrumental da ciência moderna.

Esta explosão do conhecimento, que é a herança da ciência moderna, levou à proliferação do que eu chamei de o "olho composto" do presente. É a visão multiplicada e refratada de um pós-modernismo ainda superaquecido. Não mais é a construção em trompe-loeil ${ }^{37}$ de uma pintura com perspectiva matematizada do Renascimento, o símbolo da época; ao contrário, são os olhos compostos replicados dos painéis de controle da NASA para a CBS e então para a tomada artística desses olhos compostos dentro das artes do cinema e das artes visuais. Esses olhos revelam um mundo múltiplo e pluralista.

A ambiguidade dessa maravilha, no entanto, é a duplicada relação com a tecnologia. De um lado, a ciência moderna era desde o início tecnologicamente incorporada; mas por outro, também estava tecnologicamente embutida dentro dos almejados sistemas de apoio dos poderes de uma sociedade tornando-se tecnológica. Na época em que a ampliação e as oscilações desse mundo se tornaram o que elas têm, essa relação duplicada torna-se a distorção que agora se revela na ciência tecnológica.

Ainda assim, algo mais também vem acontecendo. A própria interligação da terra, que a cultura de alta tecnologia proporcionou, tornou-se o lugar para uma sensibilidade pós-moderna começar a mostrar-se. Ninguém, penso, poderia argumentar que a sensibilidade emergente ainda tem qualquer poder significativo, porém, como uma possível mudança de gestalt, está clara e diferentemente focada do que a visão dominante.

Sua aparência é mais acentuada nas comunidades artística, literária e filosófica, cujas sensibilidades sempre visam tais mudanças, mas a sensibilidade

36 HARDING, 1986, p. 72.

37 Trompe-l'oeil termo francês que significa 'enganar os olhos'. É uma técnica artística que, com recursos de perspectiva, cria uma ilusão de ótica que faz com que formas de duas dimensões aparentem possuir três dimensões. 
pós-modernista não se limita a esse domínio. É uma sensibilidade que rejeita um sistema hierárquico, que vê como anacrônico, seja o sistema conceitual, como na metafísica tradicional da filosofia (que resulta na rejeição do fundacionismo pelos filósofos pós-modernos), ou nas artes (o que se pode dizer ao se levar o comentário crítico de Andy Warhol a sério). Se todos tiverem seu momento de fama por dez ou mais minutos, essa observação é, na verdade, uma afirmação-limite pós-moderna. Cada artista, cada atividade humana deve tomar seu lugar ao lado dos outros em uma pluralidade não hierárquica de momentos democratizados. Isso faz parte do espírito pós-moderno. Reflete-se na forma que a pluriculturalidade tomou. E isso está fora de uma das trajetórias primárias da cultura da alta tecnologia no meio de, e apesar de, sua retenção moderna anacrônica do hierárquico.

Se houvesse um rearranjo possível das hierarquias das ciências - e hoje há algumas tremulações dessa hierarquia através do desafio das ciências biológicas, em contraste com a ciência enraizadas da física e química, o resultado seria meramente uma nova hierarquia. A trajetória do pós-modernismo está longe da hierarquia, em direção a uma pluralização. Não sei, é claro, se essa sensibilidade se tornará mais ampla ou mais sedimentada do que é agora, mas ela está operante ao modo contemporâneo aparente de visão.

Argumentei que essa visão é de um olho composto, uma visão refratada por uma pluralidade de pontos de vista, cada um dos quais lança luz de perspectiva sobre seus objetos. Que entre outras coisas é o que a crítica feminista da ciência institucional tem feito em alto-relevo. As antigas tradições da história da metáfora foram desafiadas. E sua aparência hoje deve parecer não apenas "de mau gosto”, mas anacrônica. E isso também é resultado da visão pós-moderna. Que o estabelecimento de ciência é sociologicamente dominantemente masculino, desde a matemática até as ciências físicas e químicas e, exceto em ilhas isoladas como na biologia, com cientistas de grande expressão. Os argumentos de que essa situação não ocorre em uma distorção "masculinizada" ou sob a perspectiva de gênero são cada vez mais vazios. As metáforas sobre o "estupro da natureza", que tem corrido continuamente desde Bacon e perpassando discursos contemporâneos de prêmios Nobel, desmentem a inocência.

Na formação social, também, esta institucionalização da ciência permanece paralela a outras grandes corporações, tais como corporações multinacionais, bancos, ou simbolicamente o vestiário do atual Grande Football. Essas estruturas 
hierárquicas, muitas vezes autoritárias e claramente de cima para baixo, estão longe do pós-moderno.

Se o espírito pós-moderno reinasse entre essas grandes entidades, uma imagem diferente emergiria. Não é provável que o vestiário de futebol seja pluralizado de gênero num futuro próximo, mas uma verdadeira Civilização pós-moderna não faria tal atividade, que focasse na figura do macho agressivo e da testosterona como sendo a sua atividade dominante ou até mesmo a única de seu repertório. O ponto é ampliar a distorção: ter tal atividade como um esporte, como uma atividade dentre outras, é uma coisa; tomá-lo como modelo para a investigação e, finalmente, para o "controle" de toda a natureza, é outra. No entanto, a combinação da ciência institucional dentro de sua cultura tecnológica e seus patrocinadores multicorporativos e multinacionais, todos os quais apresentam as mesmas características estruturais, são eles que agora se relacionam com o reino da baleia (oceanos), as florestas tropicais (a terra) e os céus.

Assim, é do triunvirato das tragédias tecnológicas simbólicas do final do século XX; e, a despeito do tamanho do grupo de humanos mortos, o incidente "Challenger" é o mais adequado para nós e deve ter precedência simbólica sobre Bhopal ou Chernobyl, cujo impacto humano real foi e continua a ser muito maior.

O próprio nome "Challenger" [Desafiador] reflete a observação feita muito antes por Heidegger: "A revelação de que as regras da tecnologia moderna é um desafio que coloca na natureza a exigência irracional de que ela nos supra [como um bem de consumo]." ${ }^{38}$ Esse nome, pugilístico, falocêntrico, transmite esse mesmo sentido. E uma deliberação cuidadosamente planejada por meio da literatura cara e ardilosa da NASA e disseminada em praticamente todas as escolas primárias, foi o que levou professoras e mães a conduzir uma geração de crianças para o empreendimento que foi o que fez de "Challenger" o evento que era. E o evento ecoou no final de um século, precisamente o que ocorreu no início de tal século com outro nome arrogante, "Titanic".

Há também uma diferença. Enquanto o mythos reinante do “Titanic" era algo mergulhado em noções românticas como a "vingança da natureza", o incidente "Challenger" revela mais sobre o molde dos designers e tomadores de decisão da ciência tecnológica. Não foi a natureza que abateu o "Challenger"; foi muito mais o excesso de confiança da sala de comando sobre a retidão da tarefa. Nenhuma das lições mais profundas foi aprendida. O "Discovery" [Channel] acabou de ser lançado com base em uma divulgação de mídia completa similar, 
com estudantes das escolas ansiosos por assistir o canal, é um nome [Descoberta] que possui algumas nuances em relação ao domínio. E a linguagem de "reentrar" na corrida espacial mais uma vez evoca, para o pós-moderno, o contínuo falocentrismo do processo. De fato, devido a incidentes anteriores, civis e mulheres estão agora ainda mais fortemente excluídos da atividade. $\mathrm{O}$ projeto volta-se para uma população ainda mais próxima agora à do vestiário do que durante todo o período de totemismo anteriormente realizado.

Para tornar-se uma civilização pós-moderna em que haveria uma democracia e pluralização de diversas atividades humanas, tais atividades claramente falocêntricas teriam que ser restritas aos limites dos jogos propriamente ditos. Todas as atividades mais importantes teriam de ter tanto gênero quanto pluralidades culturais como sua base de ação distribuída. Não estou aqui sugerindo que, se simplesmente corrigirmos o viés de gênero da ciência tecnológica, então teremos resolvido nossos problemas. Isso é apenas parte do problema, embora seja um aspecto que a perspectiva transcultural da crítica feminista tenha feito aparecer em acentuado alívio.

Estamos de volta, mais uma vez, à pergunta equivocada do "controle", mas é e continua sendo uma questão de como se muda uma cultura tecnológica, e não simplesmente uma das tecnologias abstratas que podem e devem ser desenvolvidas. Reconheço também que estou perigosamente perto de culpar a incrustação da Grande Ciência na Grande Tecnologia pela distorção, ao mesmo tempo em que elogio o surgimento de uma visão pluralista e pós-moderna de um olho composto que poderia ser mal interpretado como uma "pequena" ciência tecnológica. Isso não é factualmente o caso, uma vez que o surgimento de um olho composto é em si o resultado de uma grande ciência e, ainda mais, conectada, tecnológica e multinacional.

A distorção presente é um desequilíbrio, possivelmente mesmo fatal, decorrente de trajetórias contrárias existentes dentro da dupla incorporação tecnológica e integração que veio a ser a situação do mundo tecnológico contemporâneo. Se, por causa da proliferação de perspectivas que constituem pluriculturalidade, com seu olho composto e novos modos de investigação, pode haver suficiente visão e equilíbrio para corrigir as tendências agora dominantes da tecnologia moderna tardia, eu não pretendo saber.

A partir deste momento, o maior de todos os sistemas tecnologicamente complexos, o sistema militar estava parado. Mesmo enquanto continua a crescer e ser desenvolvido, seu uso real é simbólico e hermenêutico, um mostrador 
indicando os pesos comparativos dos poderes que o brandiam. Suas contrapartes menores, é claro, encontram emprego suficiente em usos locais, regionais e terroristas. Estes chegam perto de nossas vidas com muita frequência. O bombardeio terrorista do voo 103 da Panam, que aconteceu em Londres, em 21 de dezembro de 1988, ocorreu exatamente uma semana antes de meu próprio voo para casa em sua nave-irmã no dia 28.

De um modo correlato, embora eu não tenha abordado sistematicamente aqui, o mesmo anacronismo moderno começou a aparecer na vida corporativa. Os Estados Unidos, preocupados com o fato de estarem ficando para trás tanto no desenvolvimento competitivo quanto no desenvolvimento tecnológico, começaram a perceber que o modelo de uma corporação hierárquica, particularmente em não envolver seus trabalhadores de forma mais relacional e democrática, tornou-se algo de certa forma jurássico. As formas mais recentes e mais dinâmicas de indústria que agora tomam forma, particularmente japonesas, são ainda mais high-tech do que seus antecessores, mas também estão embutidas em uma forma social-cultural diferente. Eles são impulsionados por uma operação relacional de consenso. São quase "socialistas" em termos de planos de apoio aos trabalhadores. Eles não seguem mais o padrão de linha de montagem único de uma indústria agora desatualizada. (E isto não é afirmar que eles também são gênero-pluralistas, preocupados com o meio-ambiente, ou que possuem direções conservacionistas!).

A tecnologia do olho composto também cresce e está sendo desenvolvida na medida em que as várias formas de redes chegam a ângulos sempre novos do globo, trazendo com eles o despertar para a pluriculturalidade não neutra. Resta saber se esse crescimento estimulará uma nova tolerância e o gosto pós-moderno por uma proliferação de todas as alternativas. Ainda se a visão múltipla do olho composto é um indicador transitório de um movimento para além do moderno, mesmo se sua forma final ainda não for uma forma clara de visão que possa ser parcialmente descrita, essa visão é múltipla, consciente da multiestabilidade, refratária e perspectivista. Atualmente, seu campo de visão, ainda não completamente formado em uma gestalt, ainda parece algo como um campo de bricolagem. Está repleto de culturas e fragmentos culturais. E os visionários da cultura popular entraram no campo com uma sensação de brincadeira, pois veem no campo uma condição para a invenção.

Pode haver uma cultura "inventada"? Se assim for, não será o resultado de um indivíduo, mas de um conjunto. A brincadeira encontrada em e entre os 
artistas das imagens-tecnologias que descobriram esta bricolagem é frequentemente sugestiva. Por exemplo, o filme Koyaaniskatsi, utilizando de forma típica pós-moderna técnicas como a fotografia em lapso de tempo, também se baseia nos sentidos do tempo Hopi (um fragmento cultural)... para nos mostrar algo sobre a nossa situação atual dentro do ambiente tecnologicamente texturizado. Aqui está uma forma de arte tecnologicamente derivada, reproduzindo reflexivamente sobre suas fontes para nos dar um vislumbre do nosso próprio mundo da vida.

Mesmo dentro do rápido levantamento das relações humano-tecnológicas e dos fragmentos culturais aqui revelados, pode-se projetar outras invenções dessa cultura. De minha parte, não seria difícil imaginar um mundo possível no qual as sensibilidades ambientais superiores dos aborígines australianos estavam ligadas a certos tipos de trajetórias de desenvolvimento de alta tecnologia. Mostrei que as estruturas existenciais das relações humano-tecnologias eram as mesmas para os instrumentos científicos e musicais, embora os respectivos "mundos" projetados por cada um fossem radicalmente diferentes. Nós exploramos e estamos explorando a profusão de instrumentos relativos ao primeiro contexto [científico]; nós somos muito conservadores com respeito a este último [musical]. Num mundo de alta tecnologia "aboriginalmente" constituído, este último poderia ser mais interessante e com uma trajetória mais fascinante do que o primeiro.

A invenção da cultura de bricolagem, no entanto, é no máximo uma variação de fantasia. Contudo, tais variações perspectivistas também fazem parte da multiestabilidade da visão pós-moderna. Elas mostram certa leveza à visão, muitas vezes não compreendida ou apreciada como parte do pós-moderno. É uma leveza "nietzschiana". O que é tomado como relativismo ou niilismo na leitura da proliferação de escolha que caracteriza a contingência acentuada do mundo tecnológico pós-moderno é negativo somente se uma escolha em última instância é considerada a única escolha valiosa. No entanto, a experimentação, a invenção, nem sempre, ou mesmo frequentemente, é tão pesada.

Os Heideggers e seus seguidores que afirmam que só um deus pode nos salvar talvez estejam esquecendo que seu antecessor, Nietzsche, preferiu que não houvesse deuses afinal, apenas deuses que dançassem. Talvez o deus que nos salva deve ser o deus que dança? No entanto, a dança também é uma conquista. A leveza de um dançarino é alcançada, não o resultado de uma orgia espontânea de entusiasmo. Os saltos desafiadores da gravidade do balé ocidental 
e os gestos ricos e estilizados da dança tradicional indiana só podem ocorrer através de longos aprendizados técnicos que fazem a dança parecer ter leveza.

A atual textura de alta tecnologia do mundo da vida é aquela em que a proliferação do possível é diversa, multiestável e muitas vezes confusa e perigosa. Resta aos habitantes a tarefa de cultivar o peso certo e a leveza do movimento para manter um equilíbrio dentro desse mundo. Nós ainda não fizemos isso, mas ainda pode ser possível aprender os movimentos. 


\section{Posfácio: EnTrevista com Don IHDE - VINTE E SETE ANOS DE Tecnologia e o Mundo da Vida}

$1^{\circ}$ de março de 2017

\section{Entrevista com o filósofo Don Ihde sobre o livro Tecnologia e o Mundo da Vida}

Maurício Bozatski: Quando o livro foi lançado há 27 anos, você detalhou quatro relações básicas entre os humanos e a tecnologia: relações de incorporação, relações hermenêuticas, relações de alteridade e relações de segundo plano. Com a emergência de novas tecnologias no campo da medicina, robótica e o uso massivo em todo o mundo de outras, como os telefones celulares, você ainda acredita que estas quatro categorias conceituais de relações são o suficiente para descrever todas as relações humano-tecnologia?

Don Ihde: De fato quando eu estava escrevendo Tecnologia e o Mundo da Vida eu considerei uma quinta relação humano-tecnologia, a relação cibernética que seria relativa às tecnologias de implante. Mas estas eram raras na época e eu mesmo tinha poucos implantes naquela época (restaurações nos dentes, suturas). Agora, sendo um homem idoso, com vários implantes (estente, joelhos, anel de válvula cardíaca, restaurações e suturas) eu adicionaria uma quinta relação. Mas Peter-Paul Verbeek tem seguido nesta direção. 
MB: Quando você falou sobre o aspecto pluricultural das tecnologias, especialmente das tecnologias de imagem, é possível entender que alguns filósofos do século XX, em sua maioria da Escola de Frankfurt, reagiram contra as mídias de massas e contra a popularização da cultura que era promovida por revistas e pela televisão. Tais reações que enfatizam os aspectos negativos das tecnologias e são descritas em conceitos tais como "colonização do mundo da vida", etc., são o resultado de uma compreensão equivocada das relações humano-tecnologia ou são reações que visam manter a chamada alta cultura acessível apenas às elites?

DI: Eu sou bastante simpático a muito da tradição da Escola de Frankfurt e quase realizei meu doutorado com o próprio Marcuse, ele estava na época em Brandeis, mas logo depois se mudou para San Diego, mas considero, sim, que há muito de um elitismo germânico contido nestas teorias. Especialmente eu não gosto de Adorno, mas hoje em dia acho Andrew Feenberg bastante compatível.

MB: Algumas recomendações foram fornecidas sobre a forma como podemos tornar a ciência tecnológica mais amigável para o planeta e à humanidade, algumas destas recomendações foram sobre a necessidade de desmitificar e desmasculinizar a ciência tecnológica. Podemos dizer que algum progresso foi realizado nesta tarefa?

DI: Este é um dos principais tópicos atualmente e, sim, eu continuo pensando que o balanço nas questões de gênero e a desmitificação são necessários. Mas as divisões são diferentes do que eram. Atualmente a emergência de um tipo de robótica, Inteligência Artificial e automação parecem ameaçar a humanidade, enquanto eu considero que haja muito de um retorno ao cartesianismo que precisa de crítica. Humanos em colaboração com as tecnologias são muito mais positivos e pode haver inovações e melhores trajetórias para o desenvolvimento. Eu não gosto muito de pós ou trans-humanismo, no entanto.

MB: O complexo militar-industrial continua direcionando o desenvolvimento da ciência e da tecnologia? A situação das humanidades e das artes melhorou, continua a mesma ou ficou pior?

DI: Existe infelizmente muito antagonismo às artes e às humanidades por parte das dimensões tecnocráticas da tecnosciência e muitas organizações universitárias humanísticas encolheram ou foram transformadas - nem todas negativamente. Eu penso que os arranjos interdisciplinares são frequentemente bastante produtivos, mas as disciplinas clássicas são muito antiquadas mesmo. 
MB: Nestes 27 anos, a relação entre a ciência-tecnologia e o meio ambiente melhorou? Aquelas crianças educadas pelos canais "National Geographic" e "Discovery Channel" que aprenderam a ter mais compaixão por nossos vizinhos animais e que são os engenheiros e cientistas de hoje são mais cuidadosos com o meio ambiente ou estão buscando os mesmos mitos do passado?

DI: Sim, graças aos documentários e mídias mais sofisticadas, muito melhorou. Humanos estão agora mais próximos e mais simpáticos ao mundo animal, mas eu me preocupo com retrocessos promovidos por aqueles que desejam glorificar a caça e a exploração animal. A ciência claramente compreende as ameaças das mudanças ambientais; os políticos não.

MB: O livro foi escrito nos anos da recente dissolução da União Soviética. Daquele momento até hoje nós temos agora a China como uma nova grande força mundial que tem o poder de gerar grande impacto, bons ou ruins, à economia e ao meio ambiente. Como você analisa esta ascensão da China para o futuro da ciência e da tecnologia e quais serão os impactos para o Ocidente?

DI: Há uma necessidade para uma mudança de atenção para o Pacífico. Quatro dos meus livros estão agora traduzidos para o Mandarim e eu realizei três viagens para realizar seminário na China (mais algumas para o Japão e para a Coréia). Mas um profundo problema continua relacionado às diferenças subjacentes à cultura antiga que é muito diferente das euro-americanas. Eu estou envolvido com pesquisas sobre a robótica nos EUA e no Japão, e as direções subculturais são bastante diferentes.

MB: O novo fenômeno tecnológico das redes sociais ajuda a criar uma atitude pós-moderna em direção a um mundo mais pluricultural ou elas estão criando uma bolha com consequências perigosas para a democracia, etc.?

DI: Eu penso que eventos políticos recentes, que foram amplamente facilitados pelas mídias sociais, são uma indicação de que as visões utópicas sobre as redes sociais são superficiais e geralmente perigosas.

MB: No livro você analisa a administração Reagan em algumas questões acerca da defesa e do orçamento para a ciência e tecnologia. O que você espera deste novo Presidente, aparentemente conservador, em questões como a destinação orçamentária, cuidado com o meio ambiente e sociedade pós-moderna? 
DI: Eu só direi que eu temo passar meus últimos anos de vida vivendo sob e através deste tempo atrasado e autoritário. Nossa atual administração representa o oposto de tudo que eu prezo: multiculturalismo, ambientalismo, bem-estar social, direitos das mulheres e das minorias e muito mais. 


\section{ÍNDICE}

Ackermann, Robert

Adams, Henry

Adams, Preston

Aristóteles

Sto. Agostinho

Aveni, A. T.

Bacon, Francis

Barthes, Roland

Bell, Alexander G.

Bennett, David H.

Bennett, William

Bhutto, Presidente Ali

Bhutto, Primeiro Ministro Benazair

Bichat, Xavier

Bleier, Ruth

Bloom, Alan

Bogart, Humphrey

Boorstein, Daniel

Buchwald, Art

Bunge, Mario

Burke, James

Callas, Maria

Carson, Rachel

Cassidy, David

Catlin, George 
Cheng Ho

Cianchi, Marco

Colombo, Cristóvão

Copérnico, Nicolau

Cotton, Charles

Crick, Francis

Cuvier, Georges

da Vinci, Leonardo

Darwin, Chales

Datini, Francesco

Demócrito

Descartes, René

Devaney, Robert L.

Dewey, John

Disney, Walt

Dreyfus, Hubert

Dubos, Rene

Durbin, Paul

Einstein, Albert

Elisenteins, Sergei

Ellul, Jacques

Ericson, Leif

Erlich, Paul

Faraday, Michael

Feebleman, James

Feyerabend, Paul

Ford, Henry

Fossey, Dian

Foucault, Michael

Franklin, Rosalind

Galilei, Galileu

Gandhi, Mahatma 
Gladwin, Thomas

Goodall, Jane

Gupta, Brijen

Hacking, Ian

Haraway, Donna

Harding, Sandra

Heelna, Patrick

Hegel, W. G. F.

Heidegger, Martin

Heim, Michael

Heisenberg, Wener

Heron de Alexandria

Ho, Cheng

Hrdy, Sarah Blaffer

Hughes, J. Donald

Husserl, Edmund

Il Moro, Ludovico

Jencks, Charles

Jonas, Hans,

Joyce, James

Kapp, Ernest

Kepler, Johannes

Kiell, Matthew

Kierkegaard, Søren

Kuhn, Thomas S.

Lakatos, Imre

Land, Arnheim

Lauden, Rachel

Lee, Bruce

Lévi-Strauss, Claude

Levinas, Emmanuel 
Levinson, Paul

Lewin, Roger

Lewis, David

Lo, Imperador Yung

Lucrécio

Lumière, Irmãos (Louis e Auguste)

Marcuse, Herbert

Marx, Karl

McCarthy, Mary

McCorduck, Pamela

Mead, Margaret

Merleau-Ponty, Maurice

Montagu, George

Mournier, Emmanuel

Mumford, Lewis

Needham, Joseph

Nehru, Jawaharlal

Nietzsche, Friedrich

Nobel, Alfred

Oppenheimer, Robert

Orego, Iris

Oresmus, Nicholas

Pascal, Blaise

Peitgen, Heinz-Otto

Perry, Admiral Matthew

Peterson, Ivars

Platão

Picasso, Pablo

Popper, Karl

Price, Derek de Solla

Proust, Marcel

Psimopoulos, M. 


\section{Ptolomeu}

Rapp, Friedrich

Reeves, Richard

Remington, Frederic

Richards, Steward

Segal, Aaron

Sellars, Wilfred

Simon, Paul

Simpson, Louis

Spallanzani, Lazzaro

Su Sung (Astrólogo Imperial)

Taylos, Frederick

Theocharis, $\mathrm{T}$.

Turing, A. M.

Vacanson, Jacques

Vitellio, Andrea

Warhol, Andy

Watson, James

Wheelwright, Philip

White, Lynn Jr.

Whitehead, Alfred North

Wilkins, Maurice

Winner, Langdon

Wright, Frank Lloyd

Yung Lo, Imperador

Zia-ul-Haq, Genernal Mohammad 
TÍTULO Tecnologia e o Mundo da Vida: do Jardim à Terra

AUTOR Don Ihde

TRADUÇÃO Maurício Fernando Bozatski

\author{
REVISÃO Marlei Maria Diedrich \\ PROJETO GRÁFICO E Mariah Carraro Smaniotto \\ DIAGRAMAÇÃO \\ CAPA Mariah Carraro Smaniotto \\ Foto da capa por Ijeab - Freepik.com \\ 3D Abelha: Honey Bee by PeteA está licenciado sob \\ a licença Creative Commons - Thingiverse.com
}

DIVULGAÇÃO Diretoria de Comunicação

FORMATO DO E-BOOK ePub e PDF

NÚMERO DE PÁGINAS PDF 307 